CECÍLIA CORRÊA LENZI

A habitação camponesa no programa MCMV

SÃO CARLOS

2017 
UNIVERSIDADE DE SÃO PAULO

INSTITUTO DE ARQUITETURA E URBANISMO

\section{A habitação camponesa no programa MCMV}

Cecília Corrêa Lenzi

Dissertação apresentada ao Instituto de Arquitetura e

Urbanismo da Universidade de São Paulo para obtenção

do título de Mestre em Arquitetura e Urbanismo.

Área de Concentração: Arquitetura, Urbanismo e Tecnologia

Orientador: Prof. Dr. João Marcos de Almeida Lopes

VERSÃO CORRIGIDA

SÃO CARLOS 
AUTORIZO A REPRODUCAO TOTAL OU PARCIAL DESTE TRABALHO, POR QUALQUER MEIO CONVENCIONAL OU ELETRONICO, PARA FINS DE ESTUDO E PESQUISA, DESDE QUE CITADA A FONTE

Ficha catalográfica elaborada pela Biblioteca do Instituto de Arquitetura e Urbanismo com os dados fornecidos pelo(a) autor(a)

Lenzi, Cecília Corrêa

A habitação camponesa no programa MCMV / Cecília Corrêa Lenzi ; orientador João Marcos de Almeida Lopes. - - São Carlos, 2017.

$142 \mathrm{p}$.

Dissertação (Mestrado - Programa de Pós-Graduação em Arquitetura e Urbanismo, Teoria e História da Arquitetura e do Urbanismo) -- Instituto de Arquitetura e Urbanismo, Universidade de São Paulo, 2017.

1. Habitação camponesa. 2. Habitação rural catarinense. 3. Produção habitacional. 4. Programa Nacional de Habitação Rural (PNHR). I. Lopes, João Marcos de Almeida, orient. II. Título. 
FOLHA DE JULGAMENTO

\section{Candidato(a): Cecilia Corrêa Lenzi}

Título da dissertação: "A habitação camponesa no programa MCMV"

Data da defesa: 11/09/2017

Orientador: Prof. Dr. João Marcos de Almeida Lopes

\section{Comissão Julgadora:}

Resultado:

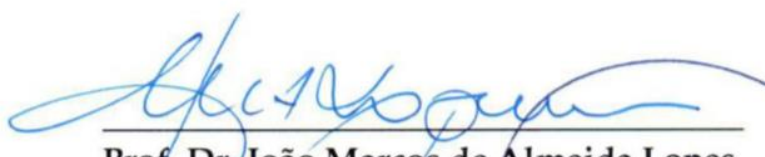

Prof. Dr.João Marcos de Almeida Lopes

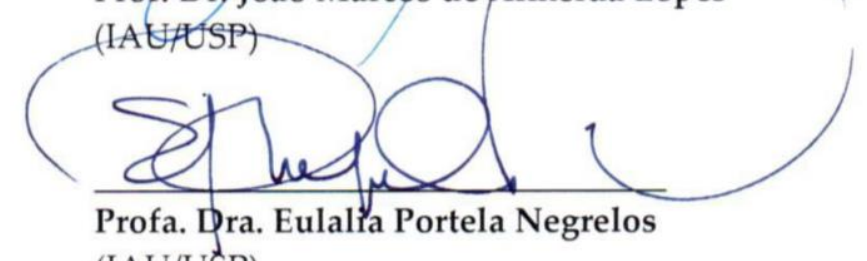

(IAU/USP)

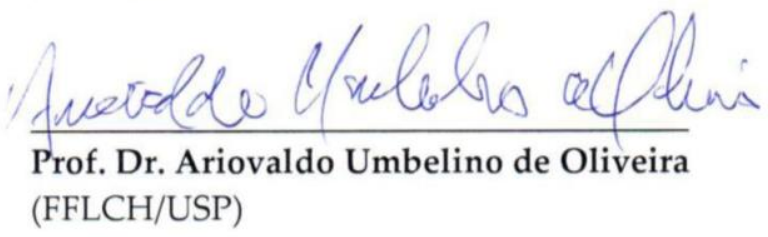

FRRONADX
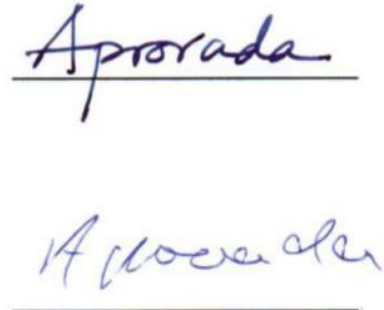
(FFLCH/USP)

Coordenadora e Presidente da Comissão de Pós-Graduação do Programa de PósGraduação em Arquitetura e Urbanismo: Profa. Dra. Cibele Saliba Rizek. 
Aos expropriados que habitam os campos, as águas e as florestas brasileiras 


\section{Agradecimentos}

À profa. Maria Inês Sugai, por me inspirar e acompanhar desde a graduação e por generosamente me apresentar o tema da habitação camponesa catarinense enquanto possibilidade de pesquisa. Ao prof. João Marcos de Almeida Lopes, pelo exemplo de arquiteto-professor que ainda nos permite acreditar nas brechas da profissão, e pelo essencial diálogo e reelaboração das ideias aqui apresentadas.

Aos técnicos da Cooperhaf e da Suhar/CEF pelo fornecimento de informações e dados que foram essenciais para o desenvolvimento deste trabalho.

Às companheiras e companheiros da Usina CTAH, com as quais aprendi outro significado da prática profissional de arquitetura e vi sentido na pesquisa acadêmica. Aos amigos, colegas e professores do grupo de pesquisa Habis, pelas conversas, debates, aprendizados e confraternizações.

Aos professores Ariovaldo Umbelino de Oliveira, Tomas Moreira, Eulália Negrelos e João Marcos pelos debates na defesa da qualificação e na defesa final. Aos professores da geografia agrária Ariovaldo e Valéria de Marco por apresentarem com humildade e grande conhecimento um Brasil não urbano ao longo das disciplinas.

À minha família, pelo suporte, em todos os sentidos. À nova avó Lúcia e à novamente avó Darcisa. Aos amigos de Yvy Porã, por não perderem a esperança. À Lúcia, Maria Helena, Elpídio, Fred, Kaya, Eros, Danuta, Thiago, Anais e Rodolfo pelas leituras do texto e debates.

À Cora e ao Joaquim, que acabaram de chegar - inspiração para a finalização deste trabalho -, e ao Fred pela cumplicidade, paciência, suporte e amor. 
Estos acordes pertenecen a una vieja canción tradicional que ya hace muchos años encontré en una zona de Caribe, en la frontera de Venezuela y Colombia. La cantava una mujer de color, la aprendi, me encantó y la caminé por el mundo. Mucha gente me la adjudica; honor hubiera sido para mi que fuera mia, pero no lo es. Es mia enquanto lo que tenga de sensibilidad en mi corazón, de cosas receptivas. Es un tema anonimo, plural, folclorico, es de ellos, de la gente morena de essa zona, frontera Venezuela Colombia.

El tema es la madre que deja su niño porque se vá al cafetal a trabajar, y deja su niño en manos de una mujer, una vecina, hermana de ella en el color, en el destino, en la vida. Y entonces, le dice que se duerma, le pide que se duerma el niño, la vecina. Y le promete que la madre le há de traer cosas que todo niño negro quisiera gustar, comer, probar; pero de adonde a veces no se puede, la vida tiene otras letras, otra condición. Le ofrece codornices, dos dolares, no puede ser. Carne de cerdo, tampoco, no puede ser. Enfin, como toda canción de cuna, pisa la tierra y es un poco metafísica. Duerme negrito, se llama.

Comentário de Atahualpa Yupanqui sobre a canção de ninar "Duerme Negrito".

duerme, duerme, negrito

que tu mama está en el campo, negrito

duerme, duerme, mobila

que tu mama está en el campo, mobila

te va traer codornices para ti, te va traer rica fruta para ti, te va traer carne de cerdo para ti, te va traer muchas cosas para ti.

y si negro no se duerme viene el diablo blanco y, izás! le come la patita jchacapumba, chacapun!

duerme, duerme, negrito que tu mama está en el campo, negrito

trabajando trabajando duramente, trabajando sí trabajando y va de luto, trabajando si trabajando y no le pagan, trabajando sí trabajando y va tosiendo, trabajando si pa'l negrito chiquitito, trabajando si no le pagan sí, va tosiendo sí, va de luto sí, duramente si

1 Transcrição a partir de vídeo disponível em https://www.youtube.com/watch?v=ROJzhe-zw98, acesso em 22/01/2017. 


\section{RESUMO}

LENZI, Cecília Corrêa. A habitação camponesa no programa MCMV. 2017. 142 f. Dissertação (Mestrado em Arquitetura e Urbanismo) - Instituto de Arquitetura e Urbanismo, Universidade de São Paulo, São Carlos, 2017.

Junto ao lançamento do programa Minha Casa Minha Vida (MCMV) em 2009 pelo governo Lula, foi relançado, como parte deste, o Programa Nacional de Habitação Rural (PNHR). Contrariando a curva histórica e em nome da redução do déficit habitacional rural, esta nova versão do PNHR ofereceu um montante de subsídios a fundo perdido nunca antes visto - chegando a ser sete vezes maior do que os programas anteriormente disponíveis - e apresentou uma meta física inicial de 120.000 unidades - correspondente a aproximadamente $12 \%$ do déficit total rural.

Porém, do ponto de vista do processo produtivo da habitação, o programa pode ser questionado sob diversos aspectos. O objetivo principal deste trabalho é analisar a produção habitacional camponesa no âmbito do programa MCMV com base na experiência de uma organização sindical em Santa Catarina. Para isso, procuramos caracterizar a luta do campesinato catarinense pela sua permanência ao longo do tempo e a trajetória dos movimentos sindicais do campo no Brasil. Também apresentamos as especificidades da versão não urbana do programa MCMV frente ao modo de vida camponês, apontando os principais aspectos do processo produtivo da casa observados em campo.

O trabalho de campo, juntamente ao referencial teórico estudado, permitiu a compreensão de que a produção da casa camponesa não pode ser analisada sob os mesmos referenciais que a habitação social urbana, pois acontece sob outra lógica. Com o suporte do referencial teórico que defende a criação e recriação do campesinato no seio do capitalismo, procuramos compreender algumas das contradições que provocam a oscilação da submissão do campesinato ao capital com base no caso estudado.

Palavras-chave: Habitação camponesa. Habitação rural catarinense. Produção habitacional. Programa Nacional de Habitação Rural (PNHR). 


\begin{abstract}
LENZI, Cecília Corrêa. The peasant's housing in the MCMV program. 2017. $142 \mathrm{f}$. Dissertação (Mestrado em Arquitetura e Urbanismo) - Instituto de Arquitetura e Urbanismo, Universidade de São Paulo, São Carlos, 2017.

Together with the launch of the program My House, My Life (Minha Casa, Minha Vida MCMV) in 2009 by the Lula government, the National Rural Housing Program (Programa Nacional de Habitação Rural - PNHR) was re-launched as part of that program. Contrary to the historical curve and with the aim of reducing the rural housing deficit, this new version of the PNHR offered an unprecedented amount of non-recoverable subsidies - up to seven times greater than previously available programs - and presented an initial physical target of 120,000 units - corresponding to approximately $12 \%$ of the total rural deficit.

However, from the perspective of the housing productive process, the program can be questioned in several aspects. The main objective of this work is to analyze the peasant housing production under the MCMV program based on the experience of a labor union organization in Santa Catarina. For this, we try to characterize the struggle of the peasantry in Santa Catarina regarding its permanence over time and the trajectory of the labor union movements in rural Brazil. We also present the specificities of the non-urban version of the MCMV program towards the peasant lifestyle, pointing out the main aspects of the house production process observed in the countryside.

The fieldwork, together with the theoretical framework studied, allowed the understanding that the production of the peasant house can not be analyzed under a framework for urban social housing, given that it happens under a different logic. With the support of the theoretical framework that advocates the creation and re-creation of the peasantry within capitalism, we seek to comprehend some of the contradictions that cause the oscillation of peasantry submission to capital based on the case examined.
\end{abstract}

Keywords: Peasant housing. Rural housing in Santa Catarina. Housing production. Programa Nacional de Habitação Rural (PNHR). 


\section{Lista de Siglas}

ABPC - Associação Brasileira do Cimento Portland

AEAPAC - Associação Estadual de Pequenos Agricultores Catarinenses

ANPUR - Associação Nacional de Pós-Graduação e Pesquisa em Planejamento Urbano e

Regional

BNH - Banco Nacional de Habitação

CADIM - Cadastro Informativo de Créditos não Quitados do Setor Público Federal

CADMUT - Cadastro Nacional de Mutuários

CEF - Caixa Econômia Federal

CREHNOR - Cooperativa de Crédito Rural Horizontes Novos de Novo Sarandi Ltda

CRESOL - Cooperativas de Crédito Rural com Interação Solidária

Contag - Confederação Nacional dos Trabalhadores na Agricultura

COOHAF - Cooperativa Habitacional de Agricultura Familiar

COOPERHAF - Cooperativa de Habitação dos Agricultores Familiares

CRAS - Centro de Referência em Assistência Social

CRE - Comissão de Representantes

CUT - Central Única dos Trabalhadores

DAP - Declaração de Aptidão ao PRONAF

EO - Entidade Organizadora

FETAESC - Federação dos Trabalhadores na Agricultura do Estado de Santa Catarina

FETRAF - Federação dos Trabalhadores e Trabalhadoras na Agricultura Familiar

FGTS - Fundo de Garantia por Tempo de Serviço

INCRA - Instituto Nacional de Colonização e Reforma Agrária

MPA - Movimento dos Pequenos Agricultores

PC - Partido Comunista

PHRRS - Programa de Habitação Rural do Rio Grande do Sul

PLS - Planilha de Liberação de Serviço

PMCMV - Programa Minha Casa Minha Vida

PMCMV-E - Programa Minha Casa Minha Vida Entidades

PNHR - Programa Nacional de Habitação Rural

PNHU - Programa Nacional de Habitação Urbana

PRO-MOVER - Associação Para o Desenvolvimento Social e Aperfeiçoamento do Cidadão

PRONAF - Programa Nacional de Fortalecimento da Agricultura Familiar 
PRONATEC -Programa Nacional de Acesso ao Ensino Técnico e Emprego

SPC - Serviço de Proteção ao Crédito

SUHAR - Superintendência Nacional de Habitação Rural

TS - Trabalho Social

ULTAB - União dos Lavradores e Trabalhadores Agrícolas do Brasil 


\section{Lista de Figuras}

Figura 1: trajeto aproximado da Estrada de Ferro São Paulo-Rio Grande no estado de Santa Catarina e perímetro de abrangência da Guerra do Contestado..............................................................................................18

Figura 2: esquema do relevo de Santa Catarina .................................................................................................22

Figura 3: Localização das mesorregiões no estado de Santa Catarina …………………………………………...2

Figura 4: Matriz da Cooperhaf no município de Chapecó em dezembro de 2014...............................................69

Figura 5: Canteiro de obras sob supervisão do Sintraf de Anita Garibaldi, em setembro de 2015 ......................71

Figura 6: Localização dos municípios visitados no trabalho de campo....................................................................73

Figura 7: Interior do Sintraf de Santa Terezinha em setembro de 2015 ..................................................................75

Figura 8: Interface online do Sistema de Informação da Cooperhaf......................................................................77

Figura 9: páginas do Caderno 1 "Orientações para a construção habitacional" do projeto "Caprichando a Morada"

Figura 10: Loja de materiais de construção que participa do PNHR em Anita Garibaldi, em setembro de 2015

Figura 11: Planta da habitação "Modelo 1".

Figura 12: Planta da habitação "Modelo 2".

Figura 13: Planta da habitação "Modelo 3".

Figura 14: Planta da habitação "Modelo 4".

Figura 15: Planta da habitação "Modelo 5".

Figura 16: Planta da habitação "Modelo 6" ........................................................................................................119

Figura 17: Planta da habitação "Modelo 7"........................................................................................................120

Figura 18: Planta da habitação "Modelo 9 acessível" .............................................................................................121

Figura 19: Prancha 01/14, planta baixa mobiliada.............................................................................................122

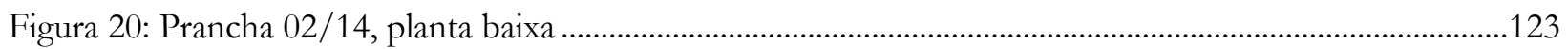

Figura 21: Prancha 03/14, corte transversal AA ................................................................................................124

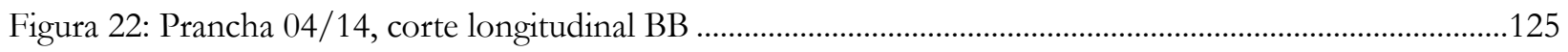

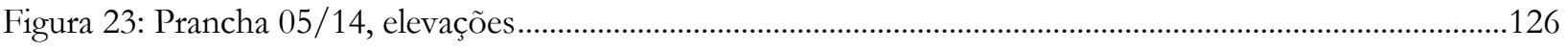

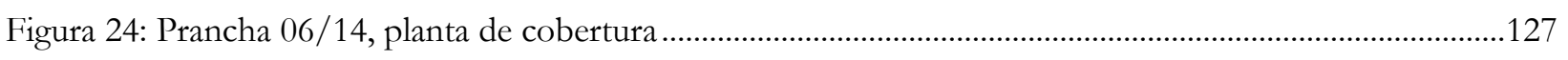

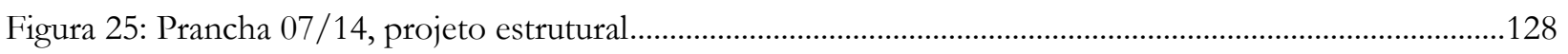

Figura 26: Prancha 08/14, projeto estrutural - detalhamento ..................................................................................129

Figura 27: Prancha 09/14, projeto elétrico ………………………………………………………………….....130

Figura 28: Prancha 10/14, projeto hidráulico ………………………………………………………………....131

Figura 29: Prancha 11/14, projeto hidráulico - detalhamento ……………………………………......................132

Figura 30: Prancha 12/14, projeto sanitário ....................................................................................................133

Figura 31: Prancha 13/14, projeto sanitário - detalhamento ..............................................................................134

Figura 32: Prancha 14/14, projeto sanitário - fossa séptica e sumidouro............................................................135 
Figura 33: Prancha A/ABCD, detalhes de acesso e banheiro ..............................................................................136

Figura 34: Prancha B/ABCD, detalhamento de acessibilidade do banheiro - vistas ...........................................137

Figura 35: Prancha C/ABCD, detalhamento de acessibilidade do banheiro - banco dobrável .........................138

Figura 36: Prancha D/ABCD, layout ampliação futura...........................................................................................139

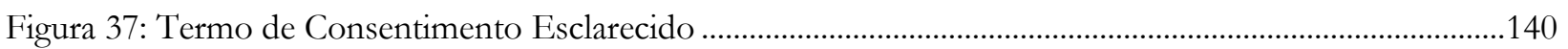




\section{Lista de Tabelas}

Tabela 1: Estabelecimentos enquadrados na Lei 11.326/2006 como da agricultura familiar..... .25

Tabela 2: Contratação por faixa de renda e modalidade do PMCMV 1 ..............................................................47

Tabela 3: Valores destinados a habitação rural nos diferentes programas do Governo Federal.........................49

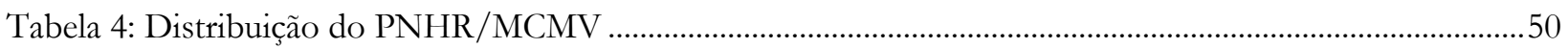

Tabela 5: relação entre produção do PNHR e número de estabelecimentos da agricultura familiar por estados e regiões

Tabela 6: produção nacional do PNHR por fases do programa MCMV até dezembro de 2016 .......................54

Tabela 7: Produção do PNHR no Brasil por regiões e grupo de acesso até dezembro de 2016 .........................55

Tabela 8: Famílias camponesas proprietárias de terra que cultivam no Brasil e por UF (\%) ...............................58

Tabela 9: Valores por unidade habitacional pelo PMCMV-E nos estados da região Sul, Espírito Santo e

Minas Gerais para construção de casas..

Tabela 10: Entidades Organizadoras atuantes em Santa Catarina, por ordem de número de contratos,

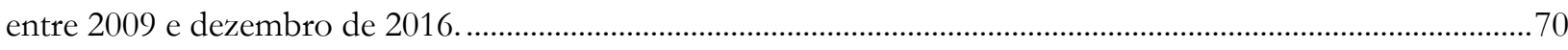

Tabela 11: Municípios com obras em andamento pela Cooperhaf em setembro de 2015 .................................72

Tabela 12: Resumo dos municípios visitados no trabalho de campo ................................................................74

Tabela 13: Comparação entre as tipologias arquitetônicas pré-aprovadas, de autoria da Cooperhaf para o PNHR .76

Tabela 14: Proveniência da mão-de-obra das obras visitadas no trabalho de campo .........................................85

Tabela 15: Proveniência dos materiais e insumos utilizados nos canteiros de obras do PNHR em SC. .87 


\section{Sumário}

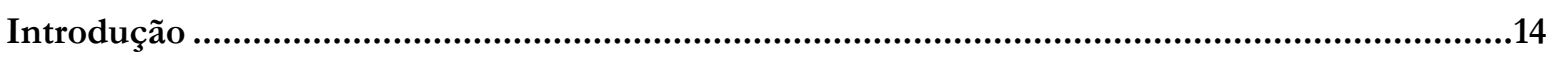

$1^{\circ}$ CAPÍTULO: “Torresmo não é carne".....................................................................17

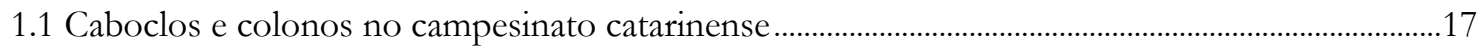

1.2 Abordagem teórico-conceitual sobre o sindicalismo e o campesinato ..............................................26

1.3 Contexto histórico das lutas camponesas e do sindicalismo no Brasil.............................................22

$2^{\circ}$ CAPÍTULO: A casa camponesa no programa MCMV ....................................................41

2.1 Lages, a "republiqueta marxista": uma referência nada anacrônica.....................................................41

2.2 A habitação camponesa como objeto de financiamento e subsídio público......................................44

2.2.1 A versão não urbana do Minha Casa Minha Vida - o PNHR/MCMV ..........................49

2.2.1.1 A questão fundiária no PNHR/MCMV ...................................................................................56

2.2.1.2 A DAP como critério de enquadramento das famílias ...........................................................59

2.2.1.3 O rebaixamento dos valores em relação ao MCMV nas cidades ..........................................60

2.2.1.4 Déficit habitacional rural versus produção do PNHR/MCMV ............................................64

2.2.1.5 A inadequação do regime de construção sob o PNHR ao modo de vida camponês........66

2.3 O “arranjo Cooperhaf/Sintraf” na produção habitacional camponesa ..............................................68

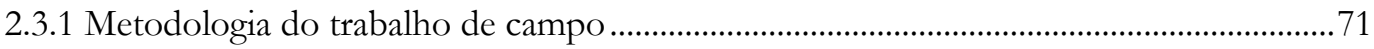

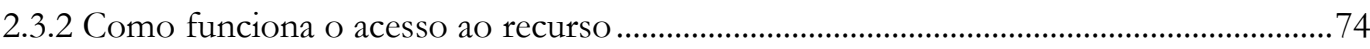

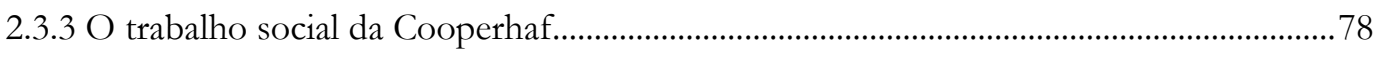

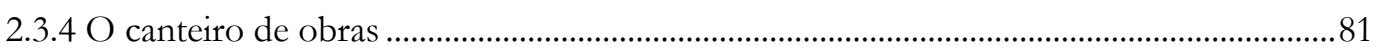

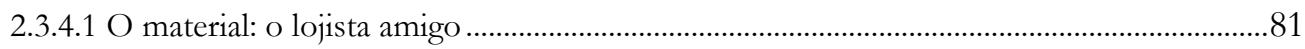

2.3.4.2 A mão-de-obra: "todo agricultor tem um pouco de pedreiro" ..............................................85

2.3.4.3 O canteiro: ferramentas e materiais de construção .................................................................86

$3^{\circ}$ CAPÍTULO: A produção da casa camponesa .......................................................... 89

3.1 A habitação como produto do autoconsumo camponês ...........................................................................89

Esboço: autoconstrução camponesa versus autoconstrução operária......................................95

3.2 O PNHR/MCMV e a submissão do campesinato ao capital..............................................................98

Considerações finais ....................................................................................103

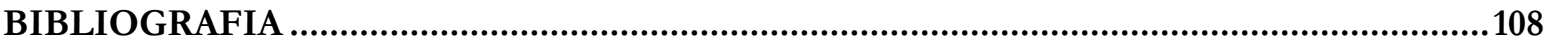

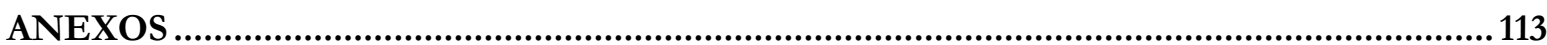




\section{Introdução}

A história documentada da habitação social no Brasil é uma história preponderantemente urbana. Não é necessário ir muito a fundo na literatura acadêmica sobre o tema para nos darmos conta de que vigora uma invizibilidade, nos textos e discursos dos autores que se dedicam à questão habitacional no Brasil, quanto ao tema da habitação para as populações dos campos, águas, florestas ou em todo território não urbano do país.

Em uma fala no ano 2000, José de Souza Martins tece críticas ao seu campo de estudos, a sociologia rural, procurando colocar em debate quais as formas ou meios que esta disciplina dispõe para eventualmente contribuir com a qualidade de vida no meio rural. Ele destaca a importância de se conhecer esta realidade para, assim, forjar nela as questões a serem trabalhadas na academia - ao invés de formular previamente as categorias para depois encaixá-las na realidade encontrada em campo. "As populações rurais, mais do que instrumentos da produção agrícola, são autoras e consumadoras de um modo de vida que é também um poderoso referencial de compreensão das irracionalidades e contradições que há fora do mundo rural” (MARTINS, 2008, p. 225).

Da mesma forma, no campo de pesquisa em arquitetura e urbanismo, não podemos buscar entender as leis gerais da produção do espaço construído ignorando esse modo de vida que insiste em continuar existindo nos outros $99,76 \%$ do território nacional ${ }^{2}$ - se da área total do país subtraírmos apenas o que efetivamente se considera "urbano". As referências projetuais e de organização espacial na quase totalidade dos cursos de arquitetura e urbanismo do país são hegemonicamente estabelecidas a partir dos modelos determinados pelos grandes centros urbanos - que ocupam apenas 0,24\% do nosso território. Mesmo sabendo que mais de 70\% dos municípios brasileiros possuem menos de 20 mil habitantes $^{3}$, temos pouca ou nenhuma oportunidade, ao longo dos anos de formação em arquitetura e urbanismo e mesmo de atuação profissional, para refletir sobre e propor intervenções nestes espaços. São as chamadas cidades pequenas, que nem mesmo plano diretor precisam ter, segundo o que acabou estabelecido no Estatuto das Cidades.

A indiferença por parte dos arquitetos urbanistas em relação ao conhecimento arquitetônico, construtivo e social que é próprio do campesinato faz transparecer uma concepção segundo a qual o mundo rural é "um mundo degradado, um mundo pária e irrelevante, lugar do nada, lugar de uma

2 Segundo levantamento do IBGE, em 2006 o uso da terra no Brasil estava assim distribuido: da area total do território nacional, que consiste em 851.487 .659 hectares, 38,75\% (329.941.393 ha) são estabelecimentos agropecuários; 36,45\% (310.371.532 ha) são terras devolutas; 14,74\% (125.545.870 ha) são territórios indígenas; 8,47\% (72.099.864 ha) são unidades de conservação; $1,35 \%$ (11.455.300 ha) são corpos d'água e apenas $\mathbf{0 , 2 4 \%}$ ( 2.075 .700 ha) estão ocupados por áreas urbanizadas.

${ }^{3}$ Segundo o último censo do IBGE, de 2010, o Brasil possui 5.565 municípios. Destes, 118 (2,12\%) possuem até 2.000 habitantes; 2.395 (43,04\%) possuem entre 2.000 e 10.000 habitantes; 1.401 (25,18\%) possuem entre 10.000 e 20.000 habitantes e apenas $1.651 \quad(29,67 \%)$ possuem mais de 20.000 habitantes (disponível em http://www.ibge.gov.br/home/estatistica/populacao/censo2010/sinopse/sinopse tab brasil zip.shtm, acessado em $16 / 11 / 2016)$ 
humanidade residual destituída de competência histórica para afirmar-se como sujeito social e como sujeito de seu próprio destino" (MARTINS, 2008, p. 225). É um mundo em extinção - pensam boa parte dos teóricos da área -, que merece do Governo Federal medidas mitigatórias de pobreza, até que se acabe. É o lugar de uma "cidadania de segunda ordem", onde seu habitante é menos cidadão por não viver na cidade, e para quem o programa habitacional vigente destina $36 \%$ do recurso investido numa moradia urbana - ou seja, praticamente $1 / 3$-, apenas porque ele vive fora do perímetro urbano e tem uma ocupação produtiva não urbana.

O campesinato, porém, não é uma população insignificante, nem numericamente, nem economicamente, no panorama nacional. Conforme procuraremos esclarecer ao longo do nosso trabalho, entendemos que o campesinato é, inclusive, funcionalmente necessário para a manutenção do sistema político e econômico vigentes - já que suas condições de reprodução permitem a realização permanente da acumulação primitiva no capitalismo ${ }^{5}$. Ainda que alguns intérpretes de dados estatísticos afirmem que a população rural está diminuindo, acreditamos - e temos boas razões para defender esta convicção, como veremos no trabalho que aqui segue - que o campesinato no Brasil não tende a desaparecer - vai seguir resistindo, apesar de tudo.

Enquanto arquitetos e acadêmicos, cabe-nos refletir sobre como podemos contribuir para a compreensão desta realidade. Além disso, se considerarmos a moradia camponesa como elemento chave neste contexto de produção e reprodução de capital - o setor primário, basicamente -, parecenos evidente a necessidade de dedicarmos uma atenção mais cuidadosa para os processos de produção desta moradia. O objetivo principal deste trabalho consiste na análise da produção habitacional camponesa no âmbito do programa Minha Casa Minha Vida (MCMV) a partir da experiência de uma organização sindical em Santa Catarina. Empreendendo uma caracterização local e particular deste modelo de produção habitacional, acreditamos que é possível clarear alguns aspectos que conformam os conteúdos políticos que se articulam a questões como a luta pela terra, aos meios de produção e aos direitos dos trabalhadores não urbanos.

O referencial teórico que norteia esta pesquisa, portanto, tem como diretriz a análise da habitação do ponto de vista de sua produção - das relações sociais estabelecidas no processo de concretização ${ }^{6}$ deste objeto que é a casa. Esta abordagem nos impele a olhar para alguns universos diferentes, que aqui distribuimos em três conjuntos, dando origem aos três capítulos que formam a estrutura desta dissertação.

${ }^{4}$ Conforme considerado por Lopes e Borges (2013)

${ }^{5}$ Conforme publicações de Ariovaldo Umbelino de Oliveira (2004 e 2010), José de Souza Martins (1981, 1989, 1994, 2008), Rosa Luxemburgo (2002), entre outros.

${ }^{6}$ Conforme Ball (1986). 
Em primeiro lugar, fez-se necessário olhar para o mundo do trabalho e para as especificidades que se colocam do ponto de vista do trabalho camponês. Para isso, iniciamos o $1^{\circ}$ capítulo com uma caracterização do campesinato catarinense a partir da Guerra do Contestado e do processo de colonização europeia de Santa Catarina, procurando identificar os caboclos e os colonos como sujeitos de luta por seus direitos e pela permanência enquanto camponeses. Na sequencia, buscamos de maneira breve compreender teórica e historicamente a constituição dos movimentos sindicais do campo no país: suas bandeiras de luta e as transformações internas que sofreram ao longo das décadas até os anos recentes.

Para introduzir a pesquisa no universo da habitação social, trouxemos como referência, no início do $2^{\circ}$ capítulo, uma experiência de gestão pública municipal democrática, que aconteceu no município catarinense de Lages na década de 1970 e teve como característica principal o incentivo à organização da população e a desmercantilização da habitação e também da produção agrícola e da educação através das iniciativas da prefeitura. É proposital o contraste com o que é apresentado na sequencia: após uma breve contextualização histórica dos programas habitacionais para o campesinato no Brasil, trazemos os aspectos principais do programa MCMV e sua versão não urbana vigente, o Programa Nacional de Habitação Rural (PNHR/MCMV). Compreendendo o PNHR/MCMV como parte da mesma estratégia político-econômica do programa MCMV, procuramos entender suas especificidades e sua compatibilidade com a realidade do campesinato brasileiro. Por fim, apresentamos como estudo de caso o processo produtivo da casa camponesa sob o PNHR/MCMV a partir da experiência catarinense de uma cooperativa ligada ao movimento sindical rural.

No $3^{\circ}$ capítulo nos dedicamos à elaboração de uma análise teórica sobre a produção da habitação camponesa. Defendemos a ideia segundo a qual o estudo da produção da casa camponesa não deve se utilizar dos mesmos referenciais teóricos da produção da habitação social urbana mas deve, pelo contrário, forjar seus próprios referenciais teóricos, uma vez que estabelece outras relações de produção, diferentes das encontradas na produção da casa operária. Para fundamentar esta afirmação buscamos respaldo na concepção teórica que defende a permanência do campesinato na realidade brasileira através de sua criação e recriação no seio do próprio capitalismo. A partir desta construção, analisamos alguns aspectos do PNHR/MCMV e suas contradições, sob a perspectiva da oscilação da submissão do campesinato ao capital. 


\section{1 CAPÍTULO: “Torresmo não é carne”}

Neste primeiro capítulo pretendemos contextualizar a formação do campesinato catarinense através de duas perspectivas principais, quais sejam, dos caboclos e dos colonos, considerando dois eventos chave: a Guerra do Contestado e o processo de colonização europeia em Santa Catarina. Na sequência, procuraremos localizar na história do sindicalismo do país a organização camponesa que constitui nosso estudo de caso. Pretendemos assim construir os elementos necessários para o debate dos capítulos seguintes.

\subsection{Caboclos e colonos no campesinato catarinense}

Torresmo não é carne, já dizia o monge João Maria (informação verbal').

A Guerra do Contestado (outubro de 1912/agosto de 1916) foi um conflito camponês de grandes proporções que evidenciou, no início do século XX, as mecânicas de entrada de capital estrangeiro no Brasil $^{8}$ e a sistemática estratégia de expropriação dos caboclos da região do planalto catarinense justificada pela construção da Estrada de Ferro São Paulo-Rio Grande, que ligaria Itararé (SP) a Santa Maria (RS) (vide Figura 1 abaixo). Junto com as expropriações de terra, diretamente relacionadas à construção da Estrada de Ferro e a cessão gratuita, aos investidores, da propriedade e usufruto das terras marginais, veio também a expropriação do modo de vida do caboclo, na época baseado na criação extensiva do gado bovino, na coleta da erva mate e na extração da araucária (AURAS, 2015, p. 32).

A origem do nome que esse conflito camponês carrega, Contestado, diz respeito à região do estado catarinense que esteve entre 1853 e 1916 em disputa entre Paraná e Santa Catarina. Esta disputa territorial tinha mais relação com o recolhimento dos impostos devidos a cada estado do que com qualquer anseio de pertencimento da população que habitava a região, para quem "nada significava o fato de pertencer a Santa Catarina ou ao Paraná. Diante das limitações da sua dura vida cotidiana, o Estado inexistia. Os 'coronéis' e o monge [...] é que representavam os marcos de referência para a sua ação e explicação de mundo" (AURAS, 2015, p. 30). A Guerra do Contestado, portanto, não teve relação alguma com a disputa territorial entre estados, já que a primeira ocorreu no plano do cotidiano e da sobrevivência do caboclo, e a segunda no plano das disputas políticas institucionais alheias à população.

A região do Contestado, uma larga faixa do planalto catarinense que se estendia a partir do limite com Paraná até o limite com o Rio Grande do Sul, tinha na época a criação extensiva do gado

${ }^{7}$ Informante 1 em entrevista à autora em setembro de 2015.

${ }^{8}$ O Grupo Farquhar, da Pennsylvania (EUA), depois de realizar investimentos em Cuba, Guatemala e El Salvador, chega ao Brasil em 1904 para investir no setor de transportes e energia (AURAS, 2015, p. 41). O grupo foi representado no Brasil pelas empresas Brazil Railway Company e sua subsidiária Southern Brazil Lumber and Colonization Company, esta última responsável pelo progressivo desmatamento da Mata Atlântica na região (ESPIG, 2012, p. 868). 
como principal atividade econômica produtiva. Os senhores das terras eram os "coronéis", e os trabalhadores de suas fazendas eram de dois tipos: os agregados - que viviam com suas famílias - e os peões - que ajudavam sazonalmente com o gado; ambos grupos de inteira confiança do "coronel". Os posseiros constituíam o grupo mais numeroso que, tendo conseguido acumular algumas cabeças de gado, deslocavam-se com suas famílias para regiões distantes das fazendas e praticavam a coleta de erva-mate e alguma produção para o autoconsumo. A situação dos posseiros era vulnerável, já que não possuíam qualquer titularidade da terra onde moravam, ficando, portanto, à mercê dos interesses de expansão territorial dos latifundiários. A matriz étnica desse campesinato - agregados, peões e posseiros - era, em sua maioria, advinda de negros e indígenas, constituindo a identidade que na região se denomina caboclo.

Figura 1: trajeto aproximado da Estrada de Ferro São Paulo-Rio Grande no estado de Santa Catarina e perímetro de abrangência da Guerra do Contestado

Fonte: elaboração própria com base em Espig (2012) e IEIJ (disponível em http://ieij.com.br/mural/418-guerra-docontestado-mapas-historicos.html, acesso em 05/02/2017)

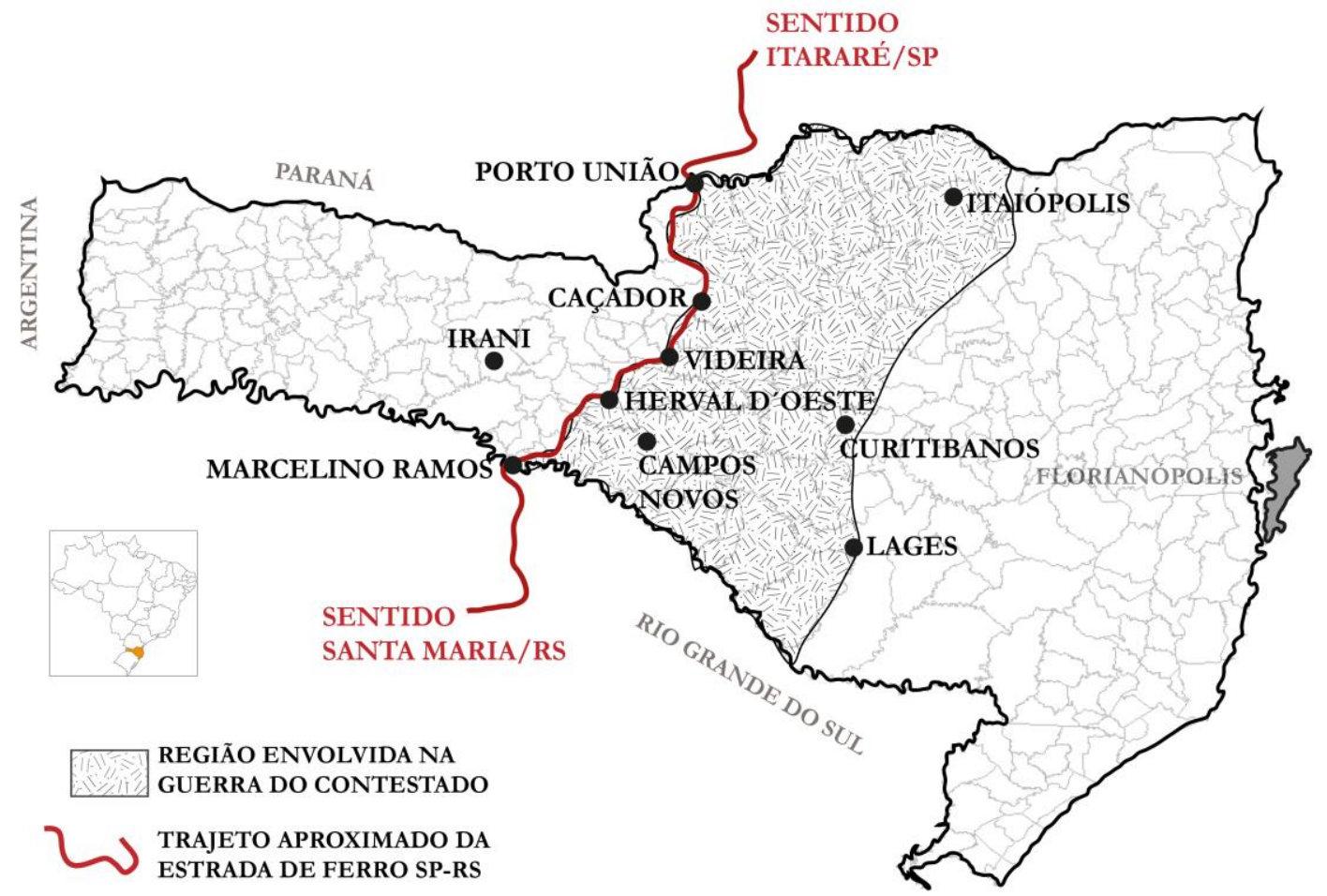

A chegada dos investimentos estrangeiros à região desmontou o frágil equilíbrio social existente. Fartamente subsidiada pelo governo central - nessa época comandado por Nilo Peçanha

9 A denominação "coronel" para os fazendeiros mais opulentos nada tinha a ver com a patente de oficial da Guarda Nacional; era um posto geralmente concedido ao chefe político local e por isso utilizamos neste texto entre aspas, conforme sugerido por Auras (2015). 
(1909/1910), Hermes da Fonseca (1910/1914) e Venceslau Brás (1914/1918) -, a empresa americana finaliza a construção da Estrada de Ferro São Paulo-Rio Grande em 1910 e toma a faixa de quinze quilômetros para ambos os lados da via férrea, conforme concedido oficialmente - totalizando uma área de aproximadamente 60 mil quilômetros quadrados ${ }^{10}$. Frente à expropriação de suas terras e de seu modo de vida e vendo desmontadas as relações de confiança determinadas pelo sistema de compadrio ${ }^{11}$ entre os caboclos e os "coronéis" devido à chegada de novos elementos de poder como o capital estrangeiro e o próprio Estado, a população cabocla acaba se vendo desamparada e destituída do pouco que lhe restava como meios de existência. Definida como a "maior guerra popular da história contemporânea do Brasil” por José de Souza Martins (1981, p. 26), o conflito teve início em 1912 e durou até 1916, teve como sedes diversos redutos no plantalto catarinense (vide Figura 1), envolveu cerca de 20 mil rebeldes e chegou a mobilizar metade do exército brasileiro para sua extinção.

O monge João Maria foi uma figura religiosa conhecida na região, na década que antecedeu a Guerra do Contestado, cuja memória e devoção foram recuperadas postumamente nos anos de conflito e serviram de inspiração aos revoltosos. É comum a rotulação desse e de outros conflitos camponeses, tal qual a Guerra de Canudos, como messianicos, devido aos temas religiosos evocados pelos revoltosos e às lideranças centralizadas em figuras proféticas. Porém, é importante identificar o fundamento ideológico dessa interpretação, entendendo que ela obscurece e até mesmo subtrai o contexto de injustiça e o sentido de luta e reivindicação social dos conflitos. A chegada de uma figura religiosa, que acolhia e dava sentido ao sofrimento daquela população, foi o elemento aglutinador do processo, mas certamente não foi a sua motivação ${ }^{12}$. Na medida em que o conflito evoluía e os caboclos venciam as batalhas contra as forças armadas do Estado, outros grupos se juntavam aos revoltosos, como foi o caso dos mais de mil trabalhadores que ficaram desempregados devido a paralisação das obras da Estrada de Ferro São Francisco - ou seja, a Guerra do Contestado passou a abrigar todos os tipos de insatisfação da população. Quando as fazendas da região e os aglomerados urbanos eram saqueados pelos "fanáticos" em busca de provisões, os cartórios onde imóveis estavam

\footnotetext{
${ }^{10}$ As fontes a respeito da extensão total da ferrovia são divergentes. Trabalhamos aqui com a extensão aproximada de $2.000 \mathrm{~km}$, a partir de Cavalcanti (1986).

${ }^{11}$ Ritual que “tratava de, ideologicamente, estabelecer um trato 'igualitário' entre as partes, baseado, objetivamente, no estilo de vida semelhante entre proprietários e não proprietários (a pobreza era generalizada, o cotidiano transcorria através da exploração dos 'mínimos vitais'), no emprego de técnicas e instrumentos rudimentares e pouco diferenciados, no uso generalizado de um equipamento ofensivo e defensivo, na relativa disponibilidade de terras" (AURAS, 2015, p. $37)$.

12 "Tendo em vista a pobreza - em todos os sentidos - reinante, a religião é o único apanágio do sertanejo: ante a insegurança e a violência do cotidiano, ela traz a proteção das forças sagradas; ante a impossibilidade de articular respostas coerentes e abrangentes às contradições vividas, ela apresenta um conjunto de certezas fundamentais. Em face de um contexto histórico que procura negar até o estatuto de homem ao sertanejo, a praxis religiosa lhe garante a possibilidade de construir sua própria identidade - pela religião ele reproduzia conhecimentos antigos e pela religião ele criava novos conhecimentos, capazes de significar o seu dia a dia" (AURAS, 2015, p. 54).
} 
registrados eram sumariamente destruídos e, pelos interiores, cercas eram desmanchadas, demonstrando claramente a sua revolta com a questão da propriedade (AURAS, 2015, p. 115). O próprio capitão Matos Costa, a cargo da missão de conter os ataques dos revoltosos, ao se inteirar da condição e visão de mundo dos rebeldes, entendeu que se tratava apenas de "uma insurreição de sertanejos espoliados nas suas terras, nos seus direitos e na sua segurança" e que "a questão do Contestado se desfaz com um pouco de instrução e o suficiente de justiça, como um duplo produto que ela é da violência que revolta e da ignorância que não sabe outro meio de se defender" (PEIXOTO, p. 94 apud AURAS, 2015, p. 112). Ainda mais clara e legítima é a seguinte nota, deixada na porta de uma casa pelos caboclos revoltosos: "O guverno da República toca os Filho Brasileiro dos terreno que pertence a nação e vende para o estrangeiro, nós agora estemo disposto a fazer prevalecer os noços direito" (PEIXOTO, p. 74 apud AURAS, 2015, p. 117). Estes relatos não deixam dúvida sobre o caráter eminentemente político de toda esta mobilização, a qual tinha o messianismo como um de seus aspectos - porém, não como o motor principal. Afinal, era disso que tratava o ditado cunhado pelo líder religioso monge José Maria, ainda antes de ter início o conflito: "torresmo não é carne". Fala de direitos a serem conquistados, da importância de não se conformar com a situação em que o povo se encontra e que é necessário sempre lutar pelo justo.

A Guerra do Contestado teve fim em 1916 com a dizimação de grande parte dos revoltosos e de seus redutos, e os camponeses caboclos de Santa Catarina seguiram sendo expropriados de suas terras, modo de vida e cultura.

Logo adiante, a partir de 1920, tiveram início os empreendimentos de colonização da região oeste do estado, no mesmo formato que já vinham sendo realizados desde meados do século XIX no litoral catarinense - ou seja, baseados na migração dos colonos vindos da Europa ou de seus descendentes já instalados no Rio Grande do Sul. As terras que se tornariam colônia, oficialmente reconhecidas como devolutas, estavam primeiro ocupadas pelos povos originários e havia muitas gerações por caboclos posseiros - para os quais a propriedade privada da terra não era uma instituição conhecida, apesar da Lei de Terras $^{13}$ ter sido aprovada havia mais de 70 anos. Para os caboclos, "a terra não era tida como mercadoria, mas um patrimônio moral que podia ser renovável” (RENK, 2009, p. 305), já que

a maioria dos caboclos estava acostumada ao deslocamento espacial, em busca de terras produtivas e da fartura, garantida por uma economia que associava atividades agrícolas a práticas de criação de animais não confinados e, ainda, a possibilidade das práticas da coleta, da caça e da pesca (BLOEMER, 2009, p. 327).

${ }^{13}$ Lei no 601 , de 18 de setembro de 1850, que determinava em seu artigo $1^{\circ}$ a compra como única forma de acesso à terra, instituindo-a como propriedade privada. Importante destacar que o artigo $2^{\circ}$ proibia a posse, implicando as penas de prisão e multa. Como veremos mais a frente, ainda hoje posseiros "de boa fé" têm dificuldade em acessar os recursos do PNHR, apesar de a lei o permitir. 
Os caboclos raramente investiram na titulação de suas posses como propriedade oficial pois a noção que carregavam era de abundância infinita: "desconheciam ou desacreditavam da possibilidade de verem suas posses se esvaindo, sendo reivindicadas ou adquiridas como terras devolutas" (p. 328). Como consequência, os novos projetos de colonização adquiriram oficialmente estas áreas e os expulsaram dali, relegando aos caboclos posseiros as parcelas de terra menos interessantes para produção agrícola e criação, ou seja, "limitando-os por cercas e documentos" (BLOEMER, 2009, p. 328), inviabilizando assim seu modo de vida: “onde a cerca aparece, é sinal da presença do colonizador e da expulsão dos caboclos" (RENK, 2009, p. 305). Bloemer (2009, p. 327) analisa que:

\begin{abstract}
o contato entre caboclos e descendentes de italianos, como aconteceu em outras áreas coloniais do Sul do país, pôs em confronto dois modos de vida distintos. Mas, sobretudo, provocou, no passado, uma disputa por território entre dois segmentos de produtores rurais que tinham na terra seu principal meio de produção. Suas diferentes formas de acesso a ela - os caboclos como posseiros e os italianos como proprietários - colocaram os primeiros em desvantagem, como "intrusos" das terras que há muito ocupavam, uma vez que a legalidade da propriedade jurídica da terra garantiu, também, a legitimidade da fixação aos italianos.
\end{abstract}

Portanto, a origem do campesinato catarinense está fortemente marcada pelas identidades e pelo confronto entre os colonos e os caboclos. Os conflitos entre ambos se expressaram inclusive na linguagem: enquanto os colonos utilizavam expressões pejorativas para se referir ao caboclo, como lagarto, mandrião ou Silva ${ }^{14}$, os caboclos julgavam os colonos por serem avarentos e ambiciosos (BLOEMER, 2009, p. 328).

A constituição da identidade do colono no estado, entretanto, não é desta época: tem início ainda no período do Império, com os primeiros projetos privados de colonização. São Pedro de Alcântara, colônia alemã, teve início em 1829, e as colônias italianas "Nova Itália" e "Nova Trento" foram fundadas em 1836, todas localizadas na faixa litorânea do estado. ${ }^{15} \mathrm{E}$ se, do ponto de vista dos caboclos, os imigrantes europeus estavam sendo favorecidos, certamente não era essa a percepção que esses colonos tinham da sua própria condição.

Os motivos para estas famílias deixarem seu país de origem - principalmente Itália e Alemanha - variavam entre escassez de terras, fragmentação das propriedades, trabalho pesado nas áreas industrializadas e baixos salários (SEYFERTH, 1999, p. 28). A propaganda realizada pelas sociedades de colonização constituiu também substancial incentivo: prometiam muito mais do que poderiam

14 "Lagarto e mandrião desqualificam pela preguiça e vagabundagem; Silva é claramente uma referência à banalidade do nome, por um lado, e a uma vegetação espinhosa que toma conta das áreas de pousio, dificultando o trabalho agrícola, por outro" (SEYFERTH, 2009, p. 291).

${ }^{15}$ Importante diferenciar esse fluxo migratório dos outros, realizados na região sudeste do país, também por colonos de origem predominantemente italiana, cuja finalidade era substituição da mão de obra escrava na produção cafeeira, e que tiveram início após a unificação da Itália (SINGER, 1968). 
entregar. Os projetos oficiais de colonização para o sul do Brasil se realizaram por um duplo interesse: as sociedades de colonização, por um lado, tinham interesse na "venda das terras a longo prazo", que seriam quitadas pelos imigrantes após se estabelecerem; por outro lado, "ao Governo Imperial interessava povoar uma área de florestas com pequenos proprietários agricultores", como forma de "abrir vias de comunicação entre o litoral e o planalto" (idem, p. 31), considerando que as escarpas da serra geral de Santa Catarina marcam uma abrupta divisão entre a região da planície litorânea e o planalto (conforme pode ser observado na Figura 2) e, à época, estavam povoadas por combativas tribos de povos originários. Esse fluxo migratório pode, de fato, ser compreendido como um fluxo de famílias de trabalhadores pioneiros destinados a explorar novas áreas; o trabalho do colono nesta época, para o governo imperial, poderia ser definido como um “trabalho 'pioneiro' de desbravamento realizado por imigrantes" (SEYFERTH, 2009, p. 280).

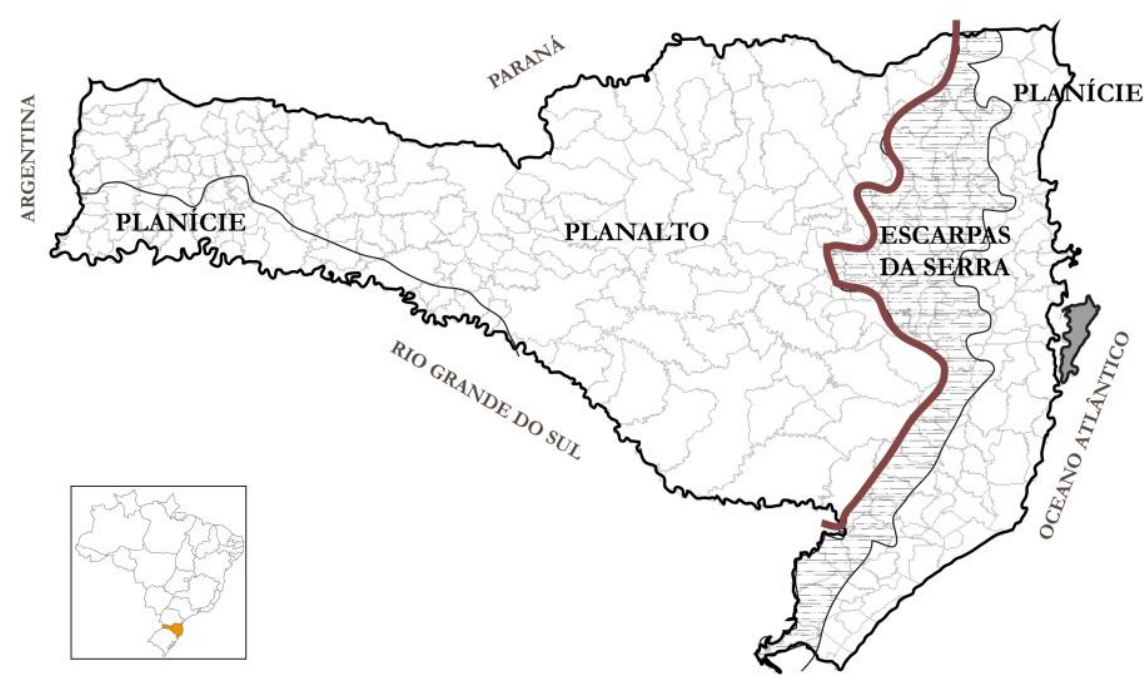

O que estes imigrantes "pioneiros" encontraram quando chegaram em Santa Catarina foi um território coberto pela mata atlântica ${ }^{16}$ e ocupado por povos originários - algumas colônias chegaram a fracassar devido aos constantes ataques dos indígenas. Famílias de colonos chegaram a ficar hospedadas nos alojamentos das instalações centrais da colônia durante um ano, sem poder ocupar as suas terras e, consequentemente, sem nelas produzir, pois estas ainda não haviam sido demarcadas. Nesse período, os que haviam trazido alguma reserva de dinheiro utilizavam-na para se alimentar, e

16 informações disponíveis no estudo de Giralda Seyferth a respeito da colonização alemã no vale do Itajaí-Mirim (SEYFERTH, 1999). 
os mais pobres davam início ao processo de seu endividamento nos estabelecimentos comerciais, que eram chamados de vendas ${ }^{17}$. Os caminhos de acesso às terras adquiridas não existiam, e os próprios colonos abriram as picadas em meio à mata para chegar até elas. As tentativas de plantar os cereais europeus - trigo, centeio e cevada - não prosperaram, e tiveram que se adaptar à cultura do milho em substituição. As recorrentes enchentes, que até hoje acontecem na região, destruíam com frequência todas as plantações dos colonos. O uso de animais domésticos em associação aos cultivos, conforme estavam habituados no país de origem, aqui não foi possível inicialmente devido as dificuldades em obter estes animais. O isolamento da área colonial em relação a outros povoados impunha a realização da policultura, "condição essencial à sobrevivência” (SEYFERTH, 1999, p. 59), reduzindo a dedicação das famílias a culturas de maior valor comercial.

$\mathrm{Na}$ comercialização de seus produtos, o colono exercia uma posição subordinada. Ele precisava de dinheiro para quitar as dívidas que iam se acumulando: desde o lote recebido pelo Império, que deveria ser pago ao longo do tempo em parcelas, até a conta na venda, que crescia conforme a necessidade de ferramentas e suprimentos para o trabalho e até mesmo de alimentos - nas épocas de perda da produção devido a geadas ou enchentes. Porém, numa economia que tinha como base a troca de produtos, havia grandes dificuldades em obter algum recurso monetário, o que tornava o colono refém da comercialização de sua própria produção. A única oportunidade de comercialização era através da venda, localizada na vila da colônia, e esta, devido ao poder de monopólio que exercia em virtude das dificuldades de acesso a outros núcleos povoados, pagava muito pouco em troca dos produtos - tão pouco que alguns colonos preferiam deixar seus produtos apodrecendo no galpão do que entregá-los a preços tão insignificantes (SEYFERTH, 1999, p. 111). Outras vezes, o vendeiro alegava que não havia dinheiro disponível e pagava com as mercadorias da própria venda. "O comércio se transformou na verdadeira fonte de acumulação de capital” (p. 117), e os vendeiros assumiam a posição de "patrões", "controlando econômica, política e culturalmente uma clientela composta de pequenos proprietários camponeses" (p. 199). Os colonos ficavam, assim, atados às relações de poder estabelecidas discricionariamente e mesmo as terras, ainda que constituíssem sua propriedade, permaneciam não quitadas.

\footnotetext{
${ }^{17}$ Locais de comercialização de produtos alimentícios, geralmente secos e molhados, provenientes da produção da própria ou de outras colônias. Além disso, era também local de encontro, conversa, debate político: “as vendas eram uma espécie de banco onde tomando um aperitivo os colonos trocavam suas ideias e na conversa comum os vendeiros impunham seu modo de pensar, juntamente com os seus preços [...] os vendeiros exerciam uma espécie de domínio cultural e político, além do econômico, pois eram também donos das notícias" (SEYFERTH, 1999, p. 118)
} 
Apesar das diferenças que constituem suas trajetórias históricas, hoje, caboclos e colonos catarinenses convivem e se reproduzem enquanto camponeses de forma similar, enfrentando os mesmos desafios cotidianos e de luta.

Enquanto, historicamente, para os caboclos a migração deu-se em busca de novas posses que garantissem igualmente $\mathrm{o}$ acesso às terras férteis, em razão do rápido esgotamento das terras originais, para os colonos italianos as disputas pelas terras por meio de movimentos migratórios de antigas colônias do Rio Grande do Sul e do Sul do estado catarinense revelam sobretudo, o desejo de ambos os segmentos de continuarem como agricultores (BLOEMER, 2009, p. 330).

Ao longo da história, a consolidação da estrutura fundiária do estado acaba também refletindo estas diferenças no padrão de ocupação do território. Segundo o Censo Agropecuário de 2006, 87\% dos estabelecimentos agropecuários de Santa Catarina estão organizados em base familiar ${ }^{18}$, os quais ocupam 43,8\% do total da área de estabelecimentos agropecuários do estado. Dentro do universo dos estabelecimentos organizados em base familiar, a condição do produtor em relação à titularidade da terra trabalhada se divide desta forma: $88 \%$ são proprietários, 3,6\% são arrendatários, 3,5\% são ocupantes, 2,3\% não possuem área, 1,5\% são assentados e apenas 1,1\% são parceiros. Ou seja, a detenção da propriedade privada da terra é uma característica do campesinato catarinense.

Se verificarmos a estrutura fundiária do estado a partir da divisão nas seis mesorregiões proposta pelo IBGE (2010), perceberemos que esta é constituída por parcelas menores nas áreas inicialmente ocupadas por colonos, onde a base da atividade econômica seguiu sendo em grande parte a produção de alimentos, enquanto que no planalto se manteve a atividade de criação extensiva de gado bovino e, ainda hoje, é a mesorregião que possui a maior concentração fundiária do estado. A proporção de estabelecimentos de base familiar em relação ao total de estabelecimentos agropecuários é mais alta nas mesorregiões Oeste, Vale do Itajaí e Sul Catarinense, com 89,5\%, 88,4\% e $88,4 \%$ respectivamente. A proporção mais baixa é na região Serrana, com $75,6 \%$ dos estabelecimentos agropecuários em base familiar. A Figura 3 localiza cada uma delas, e a Tabela 1 detalha os dados por mesorregião.

Pode-se verificar uma homogeneidade em relação à porcentagem dos estabelecimentos agropecuários que se enquadram na categoria da agricultura familiar e à área média dos lotes, excetuando a mesorregião Serrana, que apresenta uma menor porcentagem de estabelecimentos da agricultura familiar e tamanho médio de lotes acima dos demais. Também podemos verificar no mapa do estado que as áreas dos municípios dessa mesorregião são maiores com relação às demais, refletindo o padrão de propriedades de maior tamanho.

\footnotetext{
18 Segundo aferição dada pela Lei 11.326/2006, que regulamenta o enquadramento de famílias camponesas enquanto "agricultores familiares".
} 
Figura 3: Localização das mesorregiões no estado de Santa Catarina

Fonte: elaboração própria com base em IBGE (2010)

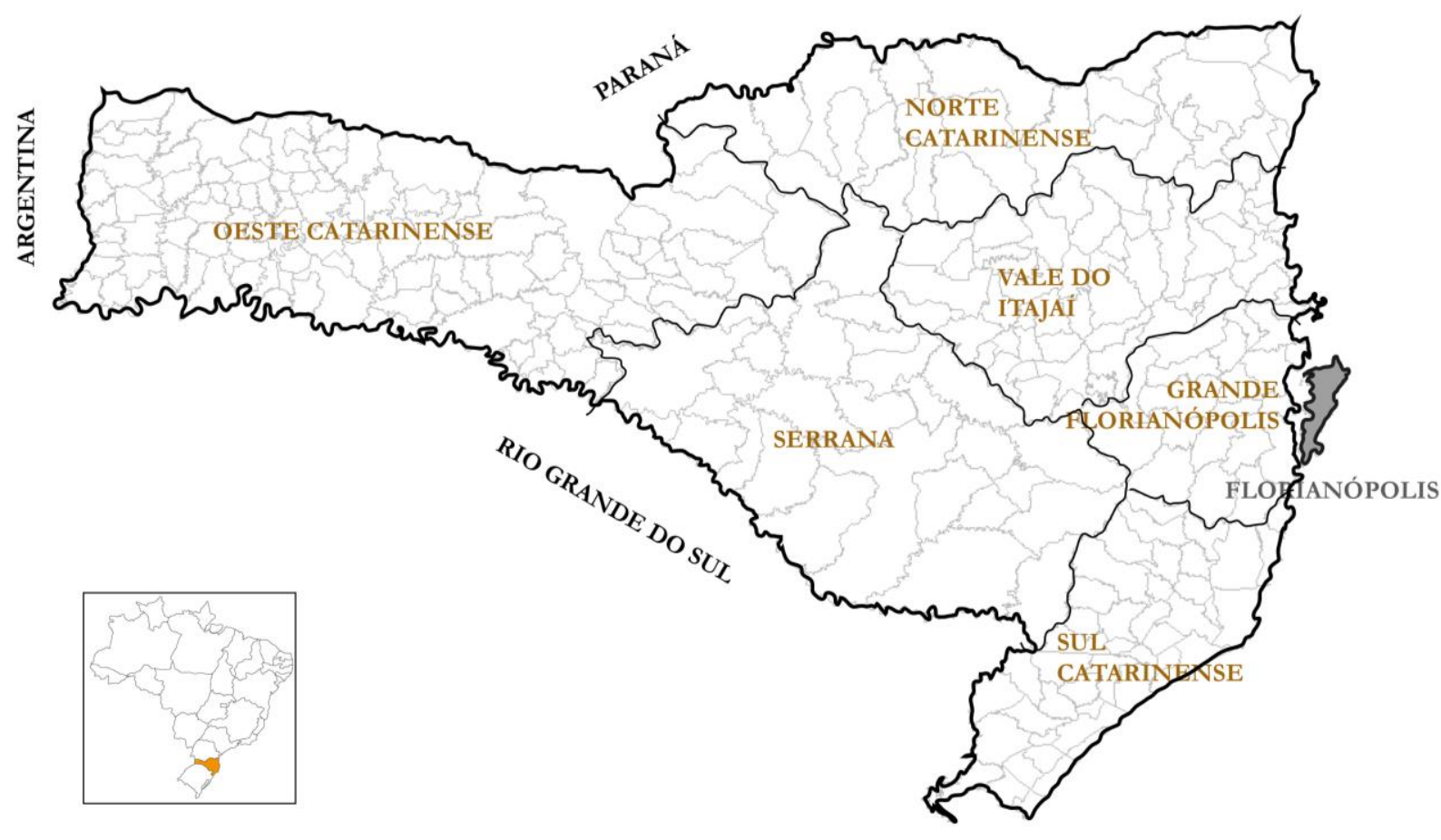

Tabela 1: Estabelecimentos enquadrados na Lei 11.326/2006 como da agricultura familiar

\begin{tabular}{lcccc}
\hline & $\begin{array}{c}\text { número de } \\
\text { estab. da A.F. }\end{array}$ & $\begin{array}{c}\text { em relação } \\
\text { ao total de } \\
\text { estab. } \\
\text { agropecuários }\end{array}$ & área (ha) & $\begin{array}{c}\text { tamanho } \\
\text { médio } \\
\text { (ha) }\end{array}$ \\
\hline Santa Catarina & $\mathbf{1 6 8 . 5 4 4}$ & $\mathbf{8 7 \%}$ & $\mathbf{1 . 6 4 5 . 0 8 8}$ & $\mathbf{1 5 , 7}$ \\
\hline $\begin{array}{l}\text { Grande } \\
\text { Florianópolis }\end{array}$ & 9.750 & $86,7 \%$ & 139.734 & 14,3 \\
\hline Norte Catarinense & 20.361 & $85,9 \%$ & 294.840 & 14,4 \\
\hline Oeste Catarinense & 73.476 & $89,5 \%$ & 1.183 .213 & 16,1 \\
\hline Serrana & 16.043 & $75,6 \%$ & 323.485 & 20,1 \\
\hline Sul Catarinense & 24.005 & $88,4 \%$ & 321.684 & 13,4 \\
\hline Vale do Itajaí & 24.909 & $88,4 \%$ & 382.131 & 15,3 \\
\hline
\end{tabular}

As mobilizações camponesas passaram a ter, após a segunda metade do século XX, outras formas de se apresentar e outros campos de protagonismo na cena política e na socidade. O sindicalismo rural foi uma destas formas e vem, desde então, desempenhando protagonismos - por vezes mais, outras menos - orientados em função dos campos de disputa que sua estrutura jurídica, política e social the permite interferir. Para auxiliar a reflexão pretendida, cabe estudarmos alguns aspectos desse modo de organização social e política no Brasil. 


\subsection{Abordagem teórico-conceitual sobre o sindicalismo e o campesinato}

Uma forma clássica de abordar teoricamente a questão do sindicalismo rural é a partir da perspectiva das relações de produção - conforme proposto por Azis Simão (1966) em seu livro "Sindicato e Estado". Nessa obra, Simão afirma que, no início da fase industrial no Brasil, ou seja, no final do século XIX, eram praticados concomitantemente três sistemas econômicos distintos: o escravista, a agricultura de subsistência e o assalariamento. Para realizar sua análise, o autor observa a quem pertenciam os meios de produção e a força de trabalho em cada um destes três sistemas econômicos. No sistema escravista, a propriedade dos meios de produção $e$ da força de trabalho estavam ambos nas mãos do senhor de escravos, o que configurava uma situação de heteronomia extrema da vida do trabalhador: no escravismo "não havia qualquer espaço para reformas internas, apenas sua manutenção ou eliminação" (SIMÃO, 1966, a partir de p. 9). Na agricultura de subsistência, pelo contrário, o autor identifica que a propriedade dos meios de produção $e$ da força de trabalho estavam ambas nas mãos do agricultor que, dentro de seu contexto social, possuía autonomia completa da reprodução de sua vida e de sua família. No terceiro sistema econômico, o assalariamento, é onde se dá a dicotomia entre a propriedade da força de trabalho e a dos meios de produção, uma vez que os últimos pertencem ao dono da fábrica e a primeira pertence ao trabalhador. Este a vende em troca de salário e reproduz assim nova forma de organização heteronômica do trabalho, onde há a disputa da maior renda entre capital e trabalho (SIMÃO, 1966, p. 61). Será desta disputa de interesses econômicos que, defende o autor, surgirá o antagonismo essencial que dará origem à luta sindical. Ou seja, a partir desse ponto de vista o sindicalismo teria uma origem essencialmente industrial e, sobretudo, urbana.

Gostaríamos de seguir a análise a partir das relações de produção e das diferentes formas de submissão do trabalho ao capital, mas faz-se necessário problematizar alguns aspectos dessa construção teórica. Se verificarmos os mesmos sistemas econômicos a partir de uma perspectiva não apenas conceitual mas histórica, perceberemos que o conflito e a reivindicação estiveram sempre presentes, trazendo maiores ou menores níveis de tensão e transformação. Até mesmo os escravos lutaram e criaram alternativas ao sistema escravista que, se certamente não eram reivindicações pertinentes ao sistema do ponto de vista conceitual, funcionaram como libertação de sua condição justamente porque não lhe eram pertinentes: fugiram e criaram as alternativas fora dali, nos territórios livres quilombolas. Ou seja, se não havia saída para si no sistema ao qual estavam submetidos, encontraram a saída em outro lugar, garantindo a manutenção de suas vidas, sua cultura e seus costumes.

Poderíamos afirmar que com o campesinato não foi diferente. A interpretação que o autor formula sobre o que chama de "agricultura de subsistência", porém, corresponde apenas a uma das 
manifestações do campesinato no Brasil, e sua descrição histórica pode conduzir à suposição de sua natural desintegração: apesar da grande autonomia do agricultor dentro da sua estrutura de relações sociais, o autor pressupõe que a expansão da lavoura mercantil teria "empurrado" a agricultura de subsistência para as parcelas de terra cada vez menores e menos férteis.

Seus agentes, quando não proprietários, viam-se, então, impelidos para lugares mais afastados ou para o mercado de trabalho. Para estes últimos, a desintegração da economia de subsistência representava, em última análise, a separação dos direitos de propriedade sobre a força de trabalho e os meios de produção, ou possibilidade de usufruto deles (SIMÃO, 1966, p. 60).

Sua análise, portanto, não abre brechas para a existência de qualquer adaptação do campesinato a novos contextos, e acaba induzindo a compreensão desse sistema como pretérito, finalizado; o destino das famílias "agricultoras de subsistência" teria sido a sua integração como assalariados no mercado de trabalho, seja ele urbano ou rural. Quanto à existência de qualquer mobilização destas famílias para manter seu modo de vida, o autor nega: "tal dicotomia não originou movimentos coletivos de resistência por parte dos agricultores que a sofriam. Os eventuais atritos em torno da propriedade territorial não chegaram a definir uma disputa essencial na sociedade da época" (SIMÃO, 1966, p. 60).

Sem pretendermos discutir a acepção de "essencial", a análise proposta por Simão acerca do campesinato certamente não pode ser generalizada: apesar de trazer elementos teóricos pertinentes, está marcada pelo momento histórico em que foi realizada e, se é coerente com determinados processos sociais em algumas regiões do Brasil, não pode ser utilizada para explicar as organizações sociais camponesas nos dias atuais. Até hoje, milhares de famílias camponesas habitam as áreas rurais brasileiras, demonstrando que não houve uma desintegração total de seu modo de vida. O que houve, certamente, foi a sua metamorfose, adaptação e integração, por outros meios, ao sistema capitalista, porém com a manutenção da célula mínima que lhe dá sentido, a produção de alimentos estruturada no trabalho da família. De todo modo, esta permanência do campesinato na sociedade brasileira não se deu sem conflitos: se por um lado ela é necessária para a própria manutenção do sistema (conforme será tratado no terceiro capítulo), a busca das condições mínimas de sobrevivência impeliu os camponeses a viverem em permanente disputa - frente às diversas formas de expropriação a que foi e vem sendo submetido, frente às diversas modalidades técnicas de produção agropecuária que a inovação tecnológica vem impondo sistematicamente, frente às políticas de desenvolvimento agrário propostas pelo governo da ocasião, e assim por diante.

Para compreendermos os fundamentos dos conflitos camponeses, precisamos buscar outras formas de interpretação das relações de produção que os envolvem. Partimos da compreensão de que o campesinato, no Brasil, estabelece outras relações de produção e se submete ao capital de outra 
forma, diferentes das que o operariado urbano estabelece no assalariamento ${ }^{19}$. Segundo esse pressuposto, o trabalho camponês é fundamentalmente caracterizado pelo trabalho em família. Idealmente, a família não compra força de trabalho nem paga salários, a não ser em momentos excepcionais do processo de produção - como a colheita, quando mais braços são necessários para a realização de determinada atividade pontual. Seu vínculo com o capital, portanto, não é estabelecido através de contratos que envolvem a venda da força de trabalho dos membros da família, mas sim através da comercialização do fruto de seu trabalho. A remuneração não é individual e sim de toda a família, e corresponde ao produto do trabalho realizado por todos. Enquanto, do ponto de vista econômico, "o operário se situa no mundo através de seu trabalho", "o camponês se situa no mundo através de seu produto" (MARTINS, 2008, p. 71, grifos no original). Sobre o camponês, Martins (2008, p. 65) indica que:

ao final do processo de trabalho ele se vê dono das coisas, dos produtos, gerados pelo trabalho. O produto do trabalho aparece como coisa acabada em suas próprias mãos. $\mathrm{O}$ que ele vende é produto e não isoladamente $\mathrm{o}$ trabalho contido no produto. É ele mesmo quem deve vender o produto para que o produto se transforme em dinheiro.

Portanto, a família camponesa é dona de seus meios de produção e o trabalho camponês não é, em si, objeto de comercialização, mas é trabalho independente. "Seu trabalho não ganha vida própria", ou seja, não é reificado, como acontece com o trabalho operário, "fundamentalmente porque ele produz diretamente seus meios de vida" (MARTINS, 2008, p. 65). O operário, para a aquisição de seus meios de vida - alimentação, vestuário, moradia, lazer -, tem que vender a sua força de trabalho. Ou seja, a obtenção de seus meios de vida é mediada pela obtenção de um salário. Para o camponês, a obtenção de boa parte de seus meios de vida não possui mediação, pois é fruto do próprio trabalho da família. Esta autossuficiência dos meios de vida essenciais é chamada de produção para o autoconsumo ${ }^{20}$, e nesta se incluem itens básico como a produção da própria casa da família, que particularmente nos interessa nesta pesquisa. Compreender a moradia como fruto do autoconsumo é essencial para a compreensão do processo de produção da habitação camponesa e as interferências que os programas habitacionais causaram sobre esta estrutura - o que será debatido mais a frente.

\footnotetext{
19 esta reflexão foi extensamente explorada por José de Souza Martins em seu texto "Situações diferenciais de classe social: operários e camponeses", e será utilizada aqui como referência principal.

${ }^{20}$ a expressão "agricultura de susbsistência", geralmente utilizada para definir a autossuficiência dos alimentos dentro do grupo, não é utilizada neste trabalho, uma vez que define um grupo fechado que não realiza trocas ou comercialização de seus excedentes.
} 
Azis Simão, portanto, tem razão quando indica que, no caso do campesinato, não ocorrerá conflitos de interesses entre o dono dos meios de produção e o dono da força de trabalho, uma vez que o camponês é dono de ambos - de seu trabalho e de suas ferramentas e sua terra ${ }^{21}$. Porém, ainda que potencialmente responsável por sua autonomia, o camponês está inserido na sociedade e com ela se relaciona. E essas relações interferem de diversas maneiras na produção e na reprodução de si e de sua família, o que dará origem a muitos conflitos de diversas ordens - que irão envolver desde a obtenção da terra, o momento da produção até o da comercialização e a disputa por fundos públicos.

\subsection{Contexto histórico das lutas camponesas e do sindicalismo no Brasil}

O certo é que os camponeses não são pacíficos e desmobilizados, mas possuem outras formas de se organizar como classe, devido a suas próprias condições de inserção na economia capitalista.

A Guerra do Contestado é o primeiro registro de revolta camponesa no estado de Santa Catarina e, assim como este, outros conflitos importantes protagonizados por camponeses ocorreram em diversas partes do Brasil, de forma dispersa, mas contundente, antes de se consolidar qualquer arranjo prático para unificação da luta do campesinato. Mas foi a partir da década de 1940 que a mobilização camponesa começa a adquirir outro significado. Diversos autores ${ }^{22}$ elegem como marco temporal o ano de 1945 para delimitar o início de um período em que "se procurou, pela primeira vez, dar-lhes uma articulação maior, através de bandeiras de luta comuns [...]. Várias organizações apareceram, conformaram-se reivindicações, conseguiram-se alguns direitos trabalhistas e colocou-se a reforma agrária na ordem do dia" (MEDEIROS, 1989, p. 14).

É importante destacar a influência determinante do trabalho político do Partido Comunista (PC) no campo neste período. Em um de seus breves momentos de legalidade, entre 1945 e 1947, o PC dá início ao trabalho militante no campo, orientando as investidas dos trabalhadores no sentido do confronto com os grandes proprietários. A introdução da própria expressão "camponês" teve origem numa iniciativa do PC, com o objetivo de facilitar a unificação das diversas formas de luta camponesa. Enquanto um partido de massas, o PC via na aproximação dos trabalhadores urbanos e rurais a força para a construção da transformação social (MARTINS, 1981, p. 21). Segundo Martins,

De acordo com este partido, o Brasil era fortemente marcado por sobrevivências feudais, cuja expressão mais evidente era o latifúndio [...]. Sob esta ótica, a extinção do latifúndio e dos latifundiários, enquanto classe, era uma necessidade do desenvolvimento do capitalismo e, portanto, contaria com o apoio de diversas classes sociais (idem, p. 27),

\footnotetext{
${ }^{21}$ Mesmo quando não tem a propriedade da terra, a arrenda e, a princípio, é ele quem decide o que fazer nela: "durante o período de vigência do aluguel dela, usará como se fosse sua" (MARTINS, 2008, p. 60)

22 Medeiros (1989), Oliveira (2007), Martins (1981) entre outros.
} 
inclusive da burguesia nacional, como comenta o autor.

As Ligas Camponesas surgiram neste mesmo contexto e foram organizações que abrigaram e unificaram as reivindicações camponesas das mais variadas origens: dos assalariados, dos meeiros, dos parceiros, dos posseiros e dos pequenos proprietários. Fundadas inicialmente como Sociedades Mortuárias, organizações que se limitavam a garantir um enterro digno aos camponeses e suas famílias, as Ligas catalizaram o potencial transformador destas Sociedades para tornarem-se instrumento organizativo de defesa de seus direitos. E foi no nordeste, entre as décadas de 1950 e 1960, em meio aos trabalhadores das usinas de cana, que o movimento ganhou corpo e presença combativa. O conflito fundiário no engenho da Galiléia, próximo a Recife, é uma referência significativa neste contexto, pois foi nessa ocasião que surgiu uma importante liderança no contexto dos enfrentamentos engendrados pelas Ligas, Francisco Julião. Nascido em um engenho e formado advogado, em 1955 ele foi demandado para atuar em defesa da causa dos arrendatários da fazenda Galiléia na disputa pelo aumento excessivo do pagamento da renda da terra, o chamado foro. Esta disputa teve sucesso em 1959, quando o decreto de desapropriação da fazenda foi assinado. O caso do engenho da Galiléia é considerado por alguns autores e movimentos sociais como o primeiro ato de reforma agrária no Brasil.

Levantando as bandeiras pela reforma agrária e contra a exploração do latifúndio, as Ligas Camponesas se espalharam por diversos estados do país ${ }^{23}$, tornando-se a primeira organização social camponesa que ensaiou alguma abrangência nacional.

O movimento das Ligas Camponesas tem, portanto, que ser entendido, não como um movimento local, mas como manifestação nacional de um estado de tensão e injustiças a que estavam submetidos os camponeses e trabalhadores assalariados do campo e as profundas desigualdades nas condições gerais do desenvolvimento capitalista no país (OLIVEIRA, 2007, p. 108).

Em 1962 e 1963, com a aprovação do Estatuto do Trabalhador Rural, a sindicalização rural é regulamentada e muitos agrupamentos das Ligas Camponesas se transformaram em sindicatos rurais. Já dentro das Ligas apareciam duas correntes ideologicamente divergentes: por um lado, o grupo que apoiava a radicalização dos conflitos e, por outro, o grupo que apoiava o caminho da institucionalização. Esta dualidade de estratégias políticas seguiria se consolidando nas mobilizações camponesas, e foi evidenciada no seu crescente processo de sindicalização: se por um lado as entidades de representação camponesa poderiam passar a ser reconhecidas pelo Estado, por outro

\footnotetext{
${ }^{23}$ Paraíba, Rio Grande do Norte, Bahia, Rio de Janeiro, Minas Gerais, São Paulo, Paraná, Rio Grande do Sul, Goiás, Mato Grosso, Acre e Distrito Federal (CAMARGO apud OLIVEIRA, 2007, p. 108).
} 
também passavam a ser por este tuteladas. Porém, por se tratar de um fruto da histórica luta dos próprios camponeses, esta regulamentação apareceu inicialmente como algo positivo:

O poder de intervenção pelo Ministério do Trabalho, a imposição de um sindicato único por município, o funcionamento com base nos recursos provenientes do imposto sindical, uma estrutura verticalizada extremamente rígida eram o reverso do reconhecimento do direito à sindicalização. Mas, nesse momento de euforia e crescimento, a legislação sindical não era questionada pelas forças hegemônicas no interior dos movimentos. O seu peso só seria percebido posteriormente, quando se verificou uma mudança radical de conjuntura (MEDEIROS, 1989, p. 63).

É neste contexto que é criada a Confederação Nacional dos Trabalhadores na Agricultura, a Contag, em janeiro de 1964, sob o governo de João Goulart, pretendendo se estabelecer como a representante única dos trabalhadores rurais. A unificação desta representação, como era exigido por lei ${ }^{24}$, ocorreu em meio a muitas disputas entre os grupos políticos que já atuavam no campo - entre eles o PCB e a Ação Popular, da igreja católica. Quando de sua fundação, a Contag assumiu como compromisso principal a retomada das resoluções do Congresso de Belo Horizonte ${ }^{25}$, fundamentalmente baseadas na reivindicação por uma reforma agrária radical ${ }^{26}$.

Porém, três meses depois, o Golpe Militar é efetivado e as estratégias de ação da Confederação sofrem profundas transformações. Foram podadas pela raiz as crescentes mobilizações por reforma agrária e demais reivindicações. As combativas Ligas Camponesas são criminalizadas, caem na clandestinidade e desaparecem em quase todos os estados brasileiros. A recém-criada Contag sofre a intervenção do governo militar e passa a ter José Rotta, ex-dirigente de uma organização da ala conservadora da igreja católica, como presidente. O período de repressão que se seguiu conduziu ao estabelecimento de outras formas de atuação, e os sindicatos rurais, mesmo após a retomada da direção das mãos dos interventores ${ }^{27}$, passaram a adotar estratégias diversas para se manter na legalidade. Nesse sentido, foram criando um padrão de ação onde o recurso à justiça formal era

${ }^{24}$ Lei no 4.214 de 2 de março de 1963, que dispõe sobre o Estatuto do Trabalhador Rural.

25 Importante evento realizado em novembro de 1961, convocado pela Ultab (União dos Lavradores e Trabalhadores Agrícolas) mas do qual participaram diversos movimentos do campo como as Ligas Camponesas e o Master (Movimento dos Agricultores Sem Terra), e estiveram presentes figuras políticas importantes no período como o próprio Presidente da República, João Goulart.

${ }^{26}$ O período pré-golpe foi muito rico no debate sobre reforma agrária, como atesta o discurso do então presidente João Goulart em 13/03/1964 no Comício da Central do Brasil: reforma agrária "com pagamento prévio e a dinheiro é negócio agrário, que interessa apenas ao latifundiário, radicalmente oposto aos interesses do povo brasileiro". Em 16/03/1964 envia mensagem ao Congresso Nacional, quando reafirma que "a ninguém é lícito manter a terra improdutiva por força do direito de propriedade", e busca providências para a imediata execução da reforma agrária (OLIVEIRA, 2007, p. 120). Em 31/03/1964 ocorreria o Golpe Militar.

27 A Contag sofreu intervenção do governo militar entre os anos de 1964 e 1968. Em 1968 acontece o I Congresso da Contag, quando é articulada uma oposição à intervenção. A oposição elege José Francisco da Silva que, apesar de legítimo camponês da Zona da Mata, durante sua gestão manteve, em diversos cargos da diretoria, integrantes que haviam sido nomeados anteriormente pelo interventor, de proveniência também da ala conservadora da igreja católica (SILVA, 2013, p. 26). 
dominante (MEDEIROS, 1989, p. 93). Perante as demandas dos camponeses sindicalizados - por exemplo, a resolução dos conflitos com proprietários de terra -, os sindicatos da Contag passaram a responder através da busca do cumprimento dos direitos já adquiridos, evitando, porém, qualquer mobilização mais combativa. "Seu princípio era: 'é preferível fazer pouco do que não fazer nada" (MEDEIROS, 1989, p. 94).

É importante frisar que a representatividade e a serventia dos sindicatos, do ponto de vista dos camponeses, eram de certa forma uma noção abstrata, tanto antes quanto depois do Golpe. Perante todas as disputas pela representação, Medeiros (1989, p. 77) relembra que "na maior parte das vezes, os trabalhadores passavam ao largo dessa disputa, que se dava no nível das direções, chegando mesmo [os camponeses] a frequentar mais de uma organização”. Nesse sentido, o desafio que se colocava era "como transformar uma unidade outorgada pelo Estado em real unidade de interesse [dos trabalhadores], que só pode[ria] se construir num processo de lutas” (MEDEIROS, 1989, p. 95).

Do ponto de vista da representatividade dos sindicatos como frente combativa e de luta, a instituição do Programa de Assistência ao Trabalhador Rural em 1971 acabou assumindo a dimensão de um golpe fatal. Conhecido como Funrural, este programa regulamentou uma antiga reivindicação dos camponeses referente a sua Previdência Social, abrangendo aposentadoria, pensão, auxílio funeral, serviços de saúde e serviço social. Sua implementação, porém, ocorreu em parceria com os sindicatos locais: os atendimentos assistenciais aconteciam todos nas sedes dos sindicatos, tornandoos referência para este tipo de serviço do Estado. Construiu-se assim, aos olhos dos camponeses, uma confusão entre o papel dos sindicatos rurais e a assistência oferecida pelo governo:

Os resultados foram perversos. Propiciando atendimento ao trabalhador numa esfera onde as carências eram enormes, este era atraído para o seu sindicato, permitindo um contato com a entidade, mas, ao mesmo tempo, conformando uma imagem dela vinculada ao Funrural e não à defesa de seus interesses" (MEDEIROS, 1989, p. 96)

A disseminação do modelo de "sindicato assistencial" foi geral. Se é possível ser inicialmente compreendido como consequência de uma imposição do governo, a sua adoção foi bastante conveniente para o fortalecimento do clientelismo nos municípios e poucos sindicatos tiraram partido da oportunidade para arregimentar camponeses para outras frentes de luta. Além da instituição do Funrural, a unicidade sindical (obrigatoriedade de unificação de um sindicato rural por município, apenas) e o imposto sindical compulsório foram decisivos na caracterização do sindicalismo rural desta época como "assistencial".

A luta por direitos e o que ela representou para tornar públicos os conflitos agrários e para a continuidade das lutas no pós-golpe, a visibilidade da luta pela reforma agrária e a capilaridade da estrutura sindical de representação 
dos trabalhadores brasileiros foram ganhos que tiveram como contrapartida uma relativa domesticação da ação sindical e um fechamento de sua organização em relação a outras forças, temas e problemas do país naquele período (FAVARETO, 2006, p. 31).

Porém, motivos não faltaram para a manutenção do ímpeto combativo na luta camponesa nas décadas da ditadura militar. A aprovação do Estatuto da Terra logo no início do governo do Marechal Castelo Branco, num primeiro momento vista pelos movimentos rurais como esperança para a efetivação da reforma agrária, mostrou-se não mais que "uma farsa histórica", como Oliveira (2007, p. 121) coloca:

A realidade passava a mostrar que, uma vez desarticulada a organização popular dos trabalhadores, o Estado, através de sua estrutura burocrárica, iria realizar a tão esperada reforma agrária. Ledo engano, pois foi o próprio Ministro do Planejamento do então governo militar, Roberto Campos, quem garantiria aos congressistas latifundiários que a lei era para ser aprovada, mas não para ser colocada em prática (OLIVEIRA, 2007, p. 121).

O que se viu ao longo do período da ditadura militar foi o contrário: planos e programas de distribuição de terra travestidos em planos de reforma agrária, cuja real intenção era a colonização de regiões despovoadas do país - como a região amazônica - para assegurar domínio territorial e desenvolvimento econômico, sendo que tais planos beneficiaram apenas os proprietários de vastas parcelas de terra, através de desapropriações com "prévias e justas indenizações". O Plano Nacional de Reforma Agrária, instrumento necessário para a sua implementação efetiva, só viria a ser elaborado nos anos 1980.

Os conflitos de terra cresceram: "Não houve, na década de 1970, um único estado da federação onde a luta pela terra não estivesse presente, de forma mais ou menos aguda" (MEDEIROS, 1989, p. 109). O recurso à justiça formal, aposta dos sindicatos ligados à Contag, foi se mostrando inócuo. A conivência das instituições judiciárias em relação aos grileiros de terra e o negligenciamento do Incra ${ }^{28}$ frente as denúncias apontadas fizeram crescer a violência no campo, e novas organizações sociais passaram a ser criadas pelos camponeses em paralelo aos sindicatos da Contag, como forma de dar vazão às demandas não atendidas através da via legal.

A ala progressista da igreja católica teve papel fundamental na construção desses novos caminhos de luta. Característica disso é a formação das Comunidades Eclesiais de Base (CEBs), que

28 “O INCRA foi criado através do Decreto-Lei no 1.110 de 09/07/1970. Em 1985 foi criado o MIRAD (Ministério da Reforma e do Desenvolvimento Agrário) absorvendo algumas responsabilidades antes do INCRA. O INCRA foi extinto em 1987. Em 1989 o MIRAD é extinto e o Congresso Nacional recria o INCRA, vinculando-o ao Ministério da Agricultura. Em 1996 é criado o Ministério Extraordinário de Política Fundiária, ao qual o INCRA se incorpora. Em 14 de janeiro de 2000, o Decreto no 3.338 criou o Ministério do Desenvolvimento Agrário (MDA), órgão ao qual o INCRA está vinculado hoje” (INCRA, 2010 apud SILVA, 2014, p. 71). Atualmente, após o golpe contra a presidenta Dilma Roussef e a consequente extinção do MDA pelo governo de Michel Temer, o INCRA encontra-se vinculado à Casa Civil, dentro da Secretaria Especial da Agricultura Familiar. 
tem início já no final da década de 1960 e que unia os rituais litúrgicos à defesa dos direitos humanos sob a ditadura (SADER, 1988). Criada em 1975, a Comissão Pastoral da Terra (CPT) concentrou sua ação nas áreas de conflito fundiário e direcionou sua atuação junto aos grupos camponeses locais, constituindo as CEBs em áreas conflagradas e colocando em debate a questão fundiária e da propriedade da terra. Em contato com o sindicalismo existente, a CPT colaborou na formação de uma crítica à atuação assistencialista, e estimulou o aparecimento de oposições dentro do movimento sindical. Seu trabalho com as bases nas áreas rurais combatia e contrastava com a hierarquia do sindicalismo contaguiano, verticalizado e conduzido unicamente por dirigentes.

A unidade sindical defendida pela Contag também foi questionada, do ponto de vista da sua capacidade de representação da diversidade de situações de trabalho no campo. As categorias de assalariado, parceiro, meeiro, posseiro e pequeno proprietário envolviam diferentes demandas, reivindicações e possibilidades de luta. O surgimento dos Movimentos dos Atingidos por Barragens - MAB - devido as obras de infraestrutura para geração de energia, dos integrados vítimas da modernização da agricultura no Sul do país entre outros, trouxeram ainda maior complexidade para a representação única da luta camponesa. E se, no discurso, a Contag defendia a unidade e a representatividade deste universo, na prática isso não acontecia: "a principal base social e os principais quadros dirigentes que se firmaram ao longo dos trinta anos de trajetória desse movimento [sindical rural] foram os produtores familiares de diferentes origens, e não os assalariados rurais" (FAVARETO, 2006, p. 27).

A priorização da Contag pela manutenção do modelo único de representação sindical foi razão, inclusive, para esta não referendar a criação da Central Única dos Trabalhadores, a CUT, em 1983. Enquanto a Contag tinha como forte diretriz interna a unidade sindical, a CUT, por sua vez, permitiu que participassem de sua construção as oposições sindicais, fato inaceitável para a Contag. Assim, ao longo dos anos, paralelamente à Contag, a CUT desenvolve uma estrutura interna própria para veiculação das reivindicações e bandeiras dos trabalhadores rurais, que se fortaleceu e culminou em 1988 na criação do Departamento Nacional de Trabalhadores Rurais (DNTR/CUT) (FAVARETO, 2006, p. 34).

Porém, mesmo nas origens do chamado "novo sindicalismo" no Brasil, no segmento rural se reproduziu uma contradição segundo a qual a base por este representada era diferente da linha política e da composição dos cargos da direção. Enquanto a base era diversificada e "abrangia uma diversidade de situações de trabalho no campo [...] e um conjunto de situações que geograficamente cobria boa parte do país, dando-lhe um porte nacional", ao mesmo tempo, porém, "o projeto político do sindicalismo rural da CUT teve por base privilegiada os agricultores familiares do eixo noroeste rio-grandense/ oeste catarinense/ sudoeste do Paraná, e os produtores de base familiar da Amazônia, 
em particular do Pará” (FAVARETO, 2006, p. 32), sendo que os representantes destas regiões vieram a ocupar os principais cargos de direção até os anos 1990.

Se na década de 1980 a polêmica se situava em saber se era ou não papel de uma central sindical organizar produtores autônomos, na condição de pequenos proprietários, o debate que aparece nos documentos sindicais na década seguinte trata da dificuldade oposta, a de atender às demandas dos assalariados rurais e criar mecanismos que aumentem sua participação numa estrutura sindical em que a larga maioria dos cargos de direção é ocupada por agricultores familiares, e na qual as principais políticas desenvolvidas são também direcionadas a esse público. A inversão nesse terreno foi tão forte que ao longo dos anos de 1990 passou a ser comum entre os sindicalistas citar a experiência de organização dos pequenos agricultores no interior da central como exemplo exitoso de como é possível trabalhar com outras dimensões do mundo do trabalho que não aquelas restritas à relação formal capital/trabalho. Era uma clara referência aos desafios do movimento operário daquele período diante da crise do emprego e dos novos padrões de acumulação (FAVARETO, 2006, p. 39).

A região Sul do Brasil também viu crescer, nas décadas de 1970 e 1980, as mobilizações e confrontos em torno da questão fundiária, fruto de uma realidade que se transformava no campo reflexo dos projetos de colonização da Amazônia mal sucedidos, dos sistemas de integração ${ }^{29}$ ao qual se submetiam os camponeses proprietários e da execução das obras de barragens para geração de energia elétrica. Com assessoria majoritaria da CPT, estes grupos se organizaram e deram origem ao Movimento dos Trabalhadores Rurais Sem Terra, que teria seu primeiro congresso nacional em janeiro de 1985 no Paraná. A sua pauta de reivindicações era focada na questão da reforma agrária mas, ao contrário do movimento sindical, pediam a extinção do Estatuto da Terra, que se mostrava conservador diante das reivindicações da época. O lema desse primeiro congresso era "Terra não se ganha, se conquista". Os sindicatos e suas federações passaram ao largo destas mobilizações.

A partir da década de 1990, após o fim do regime militar e com as transformações na política e na economia do país, a organização sindical dos trabalhadores entendeu que era necessário rediscutir seus pressupostos e melhor compreender a base social que estavam representando. No segmento rural da CUT e na própria Contag, os dirigentes passaram a perceber as modificações da realidade do campo brasileiro a partir da concepção teórica da "modernização da agricultura", entendendo-a como um processo generalizado de:

${ }^{29}$ Os sistemas de integração consistem "num contrato normativo de parceria entre o produtor familiar e a agroindústria, no qual o agricultor é responsável pela produção da matéria-prima e a empresa se responsabiliza pelo fornecimento de assistência técnica, insumos para a produção (matéria-prima, vacinas, rações etc.) e toda a logística do processo (entrega de rações e transporte da matéria-prima) (...). O produtor familiar é forçado a se adequar aos avanços tecnológicos da agroindústria para atender aos padrões exigidos para a exportação. Assim, a empresa se desonera da necessidade de ter áreas de criação e produção da matéria-prima, ao mesmo tempo em que exerce um monopólio que subordina formalmente os produtores familiares" (HENTZ, OLIVEIRA \& BATELLA, 2013). 
diminuição da importância da agricultura na formação das rendas das famílias de agricultores (Silva, 1999); um processo de concentração e especialização na agricultura de commodities; o desemprego acompanhado da flexibilização do trabalho assalariado; um adensamento da malha de municípios brasileiros, com uma aproximação entre os espaços urbanos e rurais [...] (Veiga et al., 2001); a descentralização de várias políticas públicas com impacto para a qualidade de vida das populações dos pequenos municípios e para a participação social nos mecanismos de gestão destas políticas (Abramovay, 2000; Favareto e Demarco, 2004). (FAVARETO, 2006, p. 37)

Com base na adoção desta concepção teórica, passaram a compreender também que, para a representação sindical, era necessário unificar as diferentes formas de trabalho no campo integrados, posseiros, pequenos proprietários, bóias-frias - não mais sob a denominação de "pequeno produtor", como faziam até então, mas sim sob a denominação de "agricultor familiar". Avelino Ganzer $^{30}$, em entrevista (IMS, 2012 apud SILVA, 2013, p. 64), afirma que, na busca de crédito, assistência técnica ou na relação com o governo, era difícil lidar com a inexistência de uma caracterização clara do agricultor "que produz para abastecer os pequenos mercados nas cidades" e que era preciso diferencia-lo do latifundiário. Também não consideravam suficiente a categoria "trabalhador rural”, segundo Favareto (2006), pois a percebiam como muito genérica para abarcar a diversidade existente no meio rural. A expressão "agricultura familiar" foi então a escolhida por estes dirigentes sindicais para representar a diversidade do meio rural. Ganzer cita também que os dirigentes foram à universidade buscar auxílio nesta redefinição, e confirma que alguns dos professores que serviram de referência foram José Eli da Veiga, Ricardo Abramovay e Francisco de Assis Costa.

No mesmo período em que a CUT e a Contag adotavam a nova expressão "agricultura familiar" como identidade de seus associados, elas também abandonavam uma de suas importantes bandeiras de luta - principalmente da Contag -, a da reivindicação por reforma agrária. Esta substituição é explicada como fruto de um "momento em que suas históricas bandeiras de luta eram progressivamente esvaziadas ou tomadas por outro protagonista” (FAVARETO, 2006, p. 39). A luta pela reforma agrária desde 1985 foi sendo associada ao Movimento dos Trabalhadores Rurais Sem Terra, cuja combatividade e efetividade na condução da disputa fundiária mostrou-se muito mais concreta do que as estratégias empreendidas até então pela Contag, fortemente contidas nos termos da lei. Esta nova orientação significou:

o abandono de características fundamentais que estavam na sua origem e a adoção de novas referências, pelas quais se modificam as maneiras de ver os desafios inerentes ao conflito agrário e as formas de seu equacionamento ou

${ }^{30}$ Avelino Ganzer foi vice-presidente e fundador da CUT e primeiro presidente do DNTR/CUT. Nasceu no Rio Grande do Sul e na década de 1970, no contexto dos projetos do INCRA de colonização da Amazônia, migrou com sua família para o Pará, onde iniciou seu envolvimento na vida política. 
superação; elas significaram também um realinhamento do sindicalismo rural da CUT em relação ao conjunto dos movimentos sociais rurais, marcadamente um distanciamento do novo sindicalismo em relação a parceiros históricos - como a esquerda católica representada pela CPT e seus agentes, e como o MST, nascido no mesmo contexto e sob as mesmas inspirações - e uma aproximação com o sindicalismo contaguiano, até então seu mais ferrenho oponente (FAVARETO, 2006, p. 40).

No embalo destas transformações internas, a CUT também considerou importante unir forças com o sindicalismo rural oficial, a Contag. Esta tinha de seu lado a capilaridade no meio rural brasileiro e uma relação azeitada com o Estado, o que interessava à CUT neste momento. Em 1995 a Contag filia-se à CUT, assumindo dentro da Central as bandeiras referentes às disputas relativas ao segmento rural.

A Federação dos Trabalhadores da Agricultura Familiar da região Sul (Fetraf-Sul) é fundada no início dos anos 2000, a partir da iniciativa de dirigentes do segmento rural da CUT, particularmente os do Rio Grande do Sul, Santa Catarina e Paraná. Este fato vem reforçar a representação sindical de um segmento que, conforme comentado anteriormente, já vinha ganhando espaço no sindicalismo rural brasileiro, os camponeses proprietários. Segundo Bolter (2013), os fundadores da Fetraf-Sul nutriam, desde 1995, dissidências em relação ao sindicalismo da Contag, com o qual dividiam espaço político dentro da CUT. São características desta nova federação a busca de uma proximidade entre os dirigentes e a base e, ao mesmo tempo, uma grande organicidade com o governo, reforçando ainda mais a adoção de uma prática conciliatória e propositiva em detrimento de uma prática mais contestatória e reivindicativa.

Este estreitamento do diálogo entre o sindicalismo rural e o Estado através da Fetraf-Sul se dá de diversas maneiras. É comum, em muitas das atividades desta federação, "a participação de políticos e gestores de setores importantes do governo" (BOLTER, 2013, p. 79). Os próprios dirigentes da federação frequentemente se candidatam a cargos públicos, tanto no legislativo quanto executivo dos municípios, e o reconhecimento que os eleitores têm de seu trabalho no sindicato viabiliza muitas vezes sua eleição (p. 83). Esta relação orgânica da federação com o Estado fica bem exemplificada através da adoção de uma atitude que Bolter (2013) chama de "cogestão das políticas e dos programas públicos” (p. 92). A intensa participação de seus quadros nas instâncias municipais, estaduais e federal no que diz respeito a elaboração, aperfeiçoamento e operacionalização das políticas públicas direcionadas aos camponeses chega a ocupar mais de 80\% do tempo das equipes da Federação, segundo um dirigente sindical da região sul do país entrevistado por Bolter (2013, p. 93). 
Para os agricultores, somos considerados parte do Estado, pois conhecemos e dispomos das informações sobre as políticas públicas e, em muitos casos, viabilizamos a execução das mesmas. Para o Estado, somos parte dos agricultores beneficiários das políticas públicas [...], pois conhecemos a realidade dos nossos sócios e levamos até o Estado a situação em que se encontram os agricultores [...]. (informante 1, 2011, apud BOLTER, 2013, p. 93)

Segundo Bolter (2013), a participação das organizações sindicais no processo decisório das políticas públicas proporciona prestígio e legitimidade frente aos associados, mas também frente ao Estado, às empresas privadas, aos consumidores e demais agentes envolvidos (idem, p. 94). Outro trecho das entrevistas realizadas por Bolter evidencia o benefício de os programas estarem sendo viabilizados através do sindicato, e não da prefeitura, por exemplo:

É mais fácil o agricultor chegar no sindicato do que no banco, na prefeitura ou em uma determinada empresa privada. Aqui (fazendo referência ao sindicato) o agricultor se sente em casa. Chega com as roupas que está usando na roça e ninguém se importa com formalidade e com a sua aparência, pois somos todos iguais (informante 6, 2011, apud BOLTER, 2013, p. 94)

É possível observar, portanto, que, desde o princípio da década de 1990, o sindicalismo rural brasileiro abandona uma postura mais combativa e reivindicatória - cuja centralidade estava na luta pela terra -, e começa a adotar uma postura que privilegia a negociação, mais voltada à viabilização de programas e políticas públicas para os integrantes de sua base. Este processo tem seu ápice no ano 2000 justamente com a fundação da Fetraf-Sul e, ressalvadas as diferenças entre os contextos políticos e históricos do país, podemos notar alguma semelhança entre este comportamento preconizado pela Fetraf-Sul e a postura adotada pela Contag logo após o Golpe Militar, a partir de 1964, quando os sindicatos passaram a operacionalizar a assistência social dos camponeses - e, por isso, eram confundidos com uma extensão do próprio Estado.

De fato, em nosso trabalho de campo não foram raras as vezes que ouvimos a expressão "o sindicato é a prefeitura da área rural". E também pudemos constatar, frequentemente, uma grande quantidade de serviços que seriam incumbência do Estado mas prestados ou viabilizados nas sedes dos sindicatos, como médicos e dentistas a preços reduzidos para os associados, declaração do Imposto Territorial Rural (ITR), da previdência social, auxílio para o acesso a crédito, além da operacionalização dos programas públicos como o Pronaf e o PNHR. Como comentado, muitas vezes estas tarefas burocráticas são tantas que acabam demandando grande parte do tempo do corpo técnico do sindicato - tempo este que poderia estar sendo investido na formação e organização dos camponeses para, por exemplo, reivindicarem da própria prefeitura o fornecimento deste tipo de serviço. 
É importante, porém, compreender esta postura dentro da própria contradição em que esta se encontra. A história mostra, por um lado, que essa postura do sindicato na época da fundação da Contag dificultou aos camponeses perceberem aquele espaço como acolhedor de suas reivindicações e insatisfações - e por isso alguns autores os definiram como "sindicatos assistenciais" (MEDEIROS, 1989). A prestação do serviço assistencial atraia cada vez mais integrantes para o corpo de associados, e com isso o sindicato ganhava força. Porém, por outro lado, é importante ressaltar que esta postura assistencial acaba sendo em parte decorrência da ausência do poder público nas áreas não urbanas dos municípios, fato que se reproduz cotidianamente até hoje.

É dentro do contexto contraditório desta prática sindical - da qual faz parte a Fetraf-Sul - que tem origem a Cooperativa de Habitação da Agricultura Familiar (Cooperhaf).

A Cooperhaf foi fundada em 2001 no Rio Grande do Sul, quando um grupo de representantes dos agricultores organizados - dentre eles a Fetraf-Sul, a Federação dos Trabalhadores na Agricultura no Rio Grande do Sul (Fetag-RS) e o Movimento dos Pequenos Agricultores (MPA) - conquistou, junto ao governo de Olívio Dutra, recursos para realização de um projeto-piloto ${ }^{31}$ de habitação rural (informação verbal) ${ }^{32}$ em âmbito estadual, que partia do modelo do Programa Carta de Crédito individual do CCFGTS e financiava a construção de 2 mil casas no meio rural ${ }^{33}$. O governo do estado exigia que este projeto-piloto fosse realizado com intermediação de cooperativas, e para tal a FetrafSul organizou um corpo técnico habilitado que passou a responder às demandas do sindicato relativas à produção habitacional a partir de programas públicos - a Cooperhaf.

Muitas das organizações sociais, como é o caso da Cooperhaf, foram instituídas pelas próprias organizações sindicais com o propósito de participar, de forma ativa e permanente, do processo político das ações, políticas e programas públicos voltados para o meio rural e, desse modo, contribuir na manutenção e viabilização das ações sindicais (BOLTER, 2013, p. 51).

Nos deteremos na trajetória da Cooperhaf com maiores detalhes a frente, mas neste momento é importante apenas destacar o papel ativo da cooperativa, enquanto braço técnico da Fetraf-Sul, nas fases de concepção e aperfeiçoamento dos programas de habitação rural no país. Com suas atividades inicialmente restritas ao Rio Grande do Sul, a Cooperhaf expande sua atuação para o restante da região Sul a partir de 2004, quando um programa de habitação rural em âmbito nacional ${ }^{34}$ já estava

\footnotetext{
${ }^{31}$ Segundo Bolter (2013, p. 98), o projeto-piloto se chamava "Programa Estadual de Habitação Rural” (PHRRS)

32 As informações a respeito da experiência piloto de habitação rural no RS foram cedidas à autora por Álvaro Pedrotti, arquiteto que trabalhava na Secretaria Estadual de Habitação (SEHAB-RS) na época.

33 Regulamentado pela Resolução no 372, de 17 de dezembro de 2001, que "Autoriza a execução de projeto-piloto estendendo a atuação do Programa Carta de Crédito Individual para o meio rural, e dá outras providências".

34 Segundo Bolter (2013, p. 98), este programa denominava-se inicialmente "Programa de Habitação Rural” (PHR).
} 
em operação, e Bolter (2013, p. 121) comenta que a cooperativa foi inclusive convidada a participar da idealização deste programa em nível nacional, devido a sua experiência prévia.

Por sua participação ativa no processo político dos programas de habitação rural, a Cooperhaf é hoje reconhecida pelos diversos atores que compõe o processo político do PNHR como uma das organizações que mais atuou no programa. Em certos momentos representando a Fetraf-Sul e, em outros, unida à federação, participou das negociações em torno da constituição, aperfeiçoamento e alteração das regras e normas dos programas de habitação rural [...] neste sentido, a cooperativa materializa o que denominamos um processo de interface entre o sindicalismo rural, aqui representado pela Fetraf-Sul e o Estado (BOLTER, 2013, p. 46, grifo nosso).

Se, por um lado, esta atuação pode ser interpretada como fortalecimento das instâncias de participação popular na política local, por outro lado também pode sugerir um caminho que conduz ao enfraquecimento da capacidade de mobilização da população por reivindicações que, porventura, não estejam na pauta do sindicato. A luta pela reforma agrária, por exemplo, essencial para a transformação da realidade do campo brasileiro, deixa de fazer sentido neste contexto de luta sindical (afinal, os associados são todos proprietários) e, como veremos a frente, também desaparece do debate sobre os programas habitacionais, desvinculando completamente habitação e território no contexto de formulação e implementação das políticas públicas. 


\section{$2^{\circ}$ CAPÍTULO: A casa camponesa no programa MCMV}

Após esta breve contextualização, o segundo capítulo se dedica ao trabalho de compreender a problemática dos programas habitacionais camponeses, buscando debater alguns elementos gerais do Programa Nacional de Habitação Rural, dentro do programa "Minha Casa Minha Vida" (PNHR/MCMV) frente aos programas habitacionais urbanos. Partimos das circunstâncias de como o problema da habitação camponesa aparece e é percebido em Santa Catarina para, em seguida, apresentarmos como estudo de caso as particularidades da aplicação do PNHR com base na experiência da atuação da Cooperhaf no estado.

\subsection{Lages, a "republiqueta marxista": uma referência nada anacrônica}

Em plena ditadura militar, na década de 1970, Santa Catarina foi palco de uma experiência de gestão municipal democrática a frente de seu tempo. Dirceu Carneiro, arquiteto formado em Porto Alegre pela UFRGS, assumiu a prefeitura do município de Lages pelo MDB e a administrou durante seis $\operatorname{anos}^{35}$. Graças a seu trabalho ao longo desse período, a cidade recebeu do então governador do estado Jorge Bornhausen - já um eminente representante da oligarquia catarinense - o apelido de "republiqueta marxista de Lages".

Neste período, Lages era o município com maior dimensão territorial do estado: ocupava 7.094 $\mathrm{km}^{2}$ e na época possuía 180.000 habitantes $^{36}$. A agropecuária era largamente desenvolvida em seu território, mas a atividade com maior impacto econômico até o início da década de 1970 era a extração de madeira. O escasseamento da araucária, porém, fez com que muitas serrarias e madeireiras encerrassem suas atividades, causando um grande êxodo de trabalhadores das áreas rurais para as periferias ao longo da década de 1970 (FERREIRA, 1991, p. 3). A equipe Dirceu Carneiro assumiu em 1976 com uma compreensão da gestão municipal diferente das prefeituras anteriores: entendia que "o principal problema da cidade de Lages [...] é o inchamento da sua população. Essa gente vem para a cidade porque não consegue no campo recursos suficientes para ter uma vida decente” (ALVES, 1980, p. 28). Partindo desse princípio, um dos pivôs desta nova gestão consistia num plano batizado de "Viva seu Bairro", que privilegiava o atendimento das carências nos bairros e periferias ao invés de concentrá-lo no centro da cidade. Para seu funcionamento, o "Viva seu Bairro" dependia da participação da população organizada em Associações de Bairro, onde eram debatidas as demandas locais e as formas de enfrentar os desafios que apareciam, com suporte da prefeitura - que auxiliava dentro da capacidade de seu exíguo orçamento.

\footnotetext{
35 Aos quatro anos da gestão regular somaram-se mais dois, prorrogação ocorrida em função de um decreto que adiou as eleições municipais para 1982 (FERREIRA, 1991, p. 9).

36 Segundo Censo 2010 do IBGE, Lages hoje possui $2.655 \mathrm{~km}^{2}$ de área, redução devida principalmente à emancipação de diversos de seus distritos, e sua população conta com pouco menos de 160.000 habitantes.
} 
A organização da população no contexto urbano tinha também seu correlato na zona rural, os "Núcleos Agrícolas". Procurando dar condições para os camponeses permanecerem na sua terra, a organização nos Núcleos Agrícolas tinha como objetivo encaminhar coletivamente alguns problemas que os camponeses enfrentavam no dia a dia, e que causavam, principalmente, uma baixa produtividade nas culturas que promoviam: “A razão estava no mau aproveitamento das terras, tanto do ponto de vista do que era plantado - as culturas tradicionais de milho, feijão e batatinha - como, sobretudo, da forma como era plantado" (ALVES, 1980, p. 42). A ideia da prefeitura foi então investir na diversificação das culturas tradicionais, com o auxílio constante de seus técnicos agrícolas, e na compra de tratores para serem utilizados de forma compartilhada nos Núcleos Agrícolas. Isso exigiu que os camponeses se organizassem para debater coletivamente o tempo de uso do trator por família, as prioridades etc.: "quem não se organiza, não recebe apoio" era o lema dessa gestão. Para direcionar o acesso aos equipamentos e a assistência oferecida pela prefeitura apenas aos camponeses menos favorecidos, a participação no Núcleo Agrícola era restrita às famílias que possuíam até 300 hectares ${ }^{37}$ : "Em vez de dar preferência aos grandes projetos, que requerem imensos financiamentos e geralmente beneficiam quem não precisa de ajuda por já ser muito rico, concentraram os esforços nos pequenos e médios agricultores" (ALVES, 1980, p. 41).

A equipe Dirceu Carneiro também contou com a organização da população para enfrentar a questão da falta de moradias na cidade para as famílias com renda até três salários mínimos. O Programa de Mutirão "nasceu da crença do arquiteto Dirceu Carneiro de que qualquer grupo de pessoas, com um mínimo de assistência técnica, é capaz de erguer a sua própria casa. Como faziam antigamente" (ALVES, 1988, p. 51). Uma vez que "a necessidade é a mãe da invenção, e o pessoal do Mutirão se tem revelado altamente inventivo" (ALVES, 1988, p. 52), a equipe "inventou" diversas soluções para viabilizar a construção das 690 casas de $36 \mathrm{~m}^{2}$ com recursos do apertado orçamento municipal - mas também experimentando alternativas que ensaiavam uma independência da crise do petróleo e das lojas de materiais de construção, como busca por uma autonomia da grande indústria de maneira geral. Foram diversas as soluções encontradas: exploraram uma jazida de materiais primários no próprio local da construção das casas, de onde extraíram areia e argila de primeira qualidade para a obra; os tijolos e as telhas foram fabricados em uma olaria experimental da prefeitura movida a gasogênio; a madeira utilizada para a estrutura da cobertura das casas era a da bracatinga, árvore nativa de rápido crescimento e de valor agregado muito menor do que a madeira da já escassa araucária; e, finalmente, os tijolos eram assentados com argamassa constituída apenas de barro e areia, conforme sempre se fez antes da chegada do cimento - sendo este utilizado apenas no reboco das

37 Atualmente o módulo fiscal no município de Lages é de 20 hectares, sendo, portanto, considerado como pequena propriedade a que possui até 80 hectares (equivalente a até 4 módulos fiscais) e como média propriedade a que possui até 300 hectares (equivalente a até 15 módulos fiscais). 
casas. O coração do mutirão era o "Banco de Materiais", depósito para onde eram encaminhadas madeiras, telhas e tijolos provenientes das demolições feitas na cidade - procedimento facilitado pela própria prefeitura, que agilizava a concessão de alvarás de demolição desde que os materiais fossem doados para o Banco de Materiais do Mutirão.

A experiência do Mutirão tornou-se vitrine da gestão de Dirceu Carneiro, e quando Lages recebeu o elenco da Ópera do Malandro ${ }^{38}$ - atraídos pelo sucesso da experiência democrática da prefeitura de uma forma geral -, estes ofereceram um espetáculo beneficente no município para angariar recursos para a construção de algumas casas do programa.

Mais tarde, a experiência de Dirceu Carneiro serviria de referência para a formulação de programas habitacionais para o meio rural, como o PSH-Rural do então governador Olívio Dutra no Rio Grande do Sul nos anos 2000, como veremos a frente. Essa história também merece destaque, pois se tratou de uma ação do Estado na tentativa de desmercantilizar a produção da habitação, a produção agrícola, a educação etc. através da organização popular. Este exemplo de Lages colabora na constituição de uma memória do possível.

Assim como Carneiro - que hoje já não defende mais a força do povo e tem feito declarações já não mais marxistas a respeito da atual conjuntura política nacional ${ }^{39}$, em consonância com a ala mais conservadora de seu último partido, o PSDB -, também as políticas públicas recentes em Santa Catarina não se inspiram mais nas experiências exitosas realizadas ao longo da década de 1970/1980 em Lages. E, a não ser por algumas importantes exceções ao longo da história, a habitação - em Lages, em Santa Catarina e no país inteiro - só fez assumir, cada vez mais, sua condição de mercadoria.

De todo modo, parece evidente que, pela experiência de Lages, o entendimento da habitação como um direito teve lugar e tempo definidos no estado. Se o possível aqui é promover o registro a título de ilustração, por outro lado a experiência de Lages não deixou de repercutir no difícil contexto dos anos 1970/1980, demonstrando a possibilidade de outros arranjos instituicionais que não aqueles sufocados pelo Regime Militar. Isto é, a questão urbana, do campesinato e suas relações com a cidade, da habitação em termos gerais ganha cena pública e se apresenta como objeto de políticas

\footnotetext{
${ }^{38}$ Peça de teatro brasileira escrita em 1978 de autoria de Chico Buarque e dirigida por Luís Antônio Martinez Corrêa.

${ }^{39}$ Por exemplo, em entrevista concedida a radio Simpatia FM, em 11 de maio de 2016, em sua atual cidade de residência Campos Novos, oeste do estado de Santa Catarina. Disponível no endereço < https://www.youtube.com/watch?v=Lz9FuShZlRs > em 27/12/2016.
} 
públicas - mesmo que no nível muinicipal, numa cidade relativamente sem o porte das regiões metropolitanas e sob regime de escasos recursos.

\subsection{A habitação camponesa como objeto de financiamento e subsídio público}

O campo acadêmico de pesquisa sobre habitação camponesa a partir da produção promovida através de políticas públicas no Brasil apresenta um universo relativamente pequeno de publicações a respeito. Ainda assim, as pesquisas acadêmicas que até hoje se debruçaram sobre o tema estão distribuídas em diferentes áreas do conhecimento, com destaque para a arquitetura e urbanismo - como em Peres (2003), Shimbo (2004), Arruda (2007), Leite (2009), Cerqueira (2009), Tavares (2011), Maia (2011), Barreto (2011), Sertori (2012), Medeiros (2013), Silva (2014) e Rodriguez (2016) -, economia como Martins (2009), Bolter (2013) e Santos (2014) -, agronomia ou engenharia agronômica - como Munarini (2009) e Munarini; Rover (2010) -, engenharia urbana - como Almeida (2007) -, engenharia civil - como Pinheiro (2011) - e serviço social, como Sordi (2006) e Carloto (2014). Nota-se que é a partir de 2003 que estas pesquisas começam a surgir, o que certamente se relaciona ao período em que há a generalização dos programas habitacionais para os camponeses no país e dá-se, assim, a possibilidade de analisar este fenômeno com base em uma abordagem científica.

As pesquisas acima relacionadas destacam, em unanimidade, que a habitação para famílias agricultoras nunca foi, de fato, uma prioridade para o governo. Entretanto, há bastante tempo que o assunto aparece como "prioridade formal", ao menos nos textos oficiais. Cecília Graziano da Silva (2014, p. 85) indica que o arcabouço legal da habitação camponesa no Brasil foi pela primeira vez estabelecido na Constituição de 1934, onde está registrada a preocupação de "fixar o homem no campo". Andrea Arruda (2007, p. 53) destaca que, no artigo 75 do Estatuto da Terra, de 1964, aparece a preocupação com o "nível sanitário" da população rural, problema que deveria ser atacado através da assistência técnica para a saúde, saneamento e melhorias habitacionais. O governo de Figueiredo, entre 1979 e 1985, lançou diversos decretos relativos a política fundiária que incluíam projeto e construção de moradias para o trabalhador rural, inclusive envolvendo recursos do Banco Nacional de Habitação (BNH). Arruda (2007, p. 54) alerta, entretanto, que foram todos revogados e que não se teve notícia de sua aplicação. A Constituição de 1988, por sua vez, se por um lado consolidou conquistas históricas da luta por políticas urbanas - como a inclusão dos artigos 182 e 183 a respeito da função social da cidade e da propriedade no meio urbano (ARRUDA, 2007, p. 52) -, por outro lado representou uma derrota para os movimentos de luta por reforma agrária, como vimos no $1^{\circ}$ capítulo desta dissertação.

A primeira iniciativa efetiva de financiamento público federal para produção de moradias no meio rural no Brasil foi aquela incorporada no âmbito do Crédito Instalação: um programa de concessão de recursos parcialmente subsidiados, operado desde 1985 pelo INCRA e direcionados 
exclusivamente aos assentados da reforma agrária. Dentre as diversas modalidades de financiamento disponibilizadas pelo Crédito Instalação ${ }^{40}$ - todas elas destinadas às primeiras necessidades da família quando da entrada no novo lote -, está a linha "Aquisição de Material de Construção", que poderia ser utilizada para a compra de materiais e pagamento de mão de obra, e também a linha "Recuperação/Materiais de Construção", que poderia ser utilizada para reformar unidades habitacionais pré-existentes. Em 2014 o valor disponível pelo Crédito Instalação, por família, estava fixado em $\mathrm{R} \$ 15.000,00$ e $\mathrm{R} \$ 8.000,00$ respectivamente.

No ano 2000 o mesmo Crédito Instalação passa a ser executado também através de uma parceria entre INCRA e Caixa Econômica Federal (CEF), a partir dos recursos oriundos do "Programa Carta de Crédito com Operações Coletivas - FGTS" (CC-FGTS), inicialmente com abrangência apenas nas regiões Centro-Oeste e Nordeste do país e a partir de 2001 também na região Sul e Sudeste (SILVA, 2014, p. 86). A autora esclarece que a diferença entre os dois modelos - o Crédito Instalação viabilizado exclusivamente pelo INCRA e o mesmo viabilizado pela parceria INCRA-CEF - consistiu na origem dos recursos para a garantia caução que, no primeiro caso, era aportada pelo Orçamento Geral da União (OGU) via INCRA e, no segundo caso, era aportada pelo próprio assentado. Também destaca que "pela primeira vez desde a inclusão do trabalhador rural no FGTS em 1988, os recursos desse fundo são destinados às famílias rurais” e, além disso, também pela primeira vez "a CEF opera programas habitacionais no mundo rural” (SILVA, 2014, p. 86).

Para os demais camponeses, ou seja, os não beneficiários da reforma agrária, o primeiro programa de habitação surge apenas em 2002, chamado Programa de Subsídio à Habitação de Interesse Social Rural (PSH-Rural) ${ }^{41}$, que nasce como projeto-piloto restrito apenas ao Rio Grande do Sul. O PSH-Rural passou a ter abrangência nacional a partir de 2003, quando o recém-eleito presidente Lula convoca o então governador do Rio Grande do Sul, Olívio Dutra, para assumir o novo Ministério das Cidades. Bolter (2013) conta que a Fetraf-Sul, a Contag, o Movimento dos Pequenos Agricultores (MPA) e outros grupos "ligados ao meio rural passaram a dialogar diretamente

${ }^{40}$ As modalidades do Crédito Instalação são: Apoio Inicial, destinado a compra de alimentos, ferramentas, insumos, animais, etc. para o início do ciclo produtivo; Aquisição de Material de Construção, destinado à aquisição de materiais de construção incluindo o pagamento de mão de obra e serviço técnico específico para qualificações de habitações; Fomento, destinado à aquisição de insumos e ferramentas relativos à atividade produtiva; Adicional Semiárido, destinado a implação de obras que visem proporcionar segurança hídrica às famílias, soluções em captação, armazenamento e distribuição de água; Recuperação/Materiais de Construção, destinado à melhoria das habitações; Reabilitação de Crédito Produção, destinado a recuperar a capacidade de acesso a novos créditos às famílias que contrataram financiamentos no âmbito do PROCERA (Programa Especial de Crédito para a Reforma Agrária); Apoio Mulher, Adicional Fomento; Crédito Ambiental. Os créditos devem ser pagos em até 20 anos em prestações anuais sucessivas (SILVA, 2014, p. 75).

41 Bolter (2013) utiliza em seu trabalho terminologias diferentes para denominar os programas de habitação estaduais e nacionais. O PSH-rural em sua primeira versão estadual, por exemplo, é chamado pelo autor de Programa de Habitação Rural do Rio Grande do Sul (PHRRS). Optamos por utilizar em nosso trabalho as terminologias mais comumente utilizadas pelos demais autores que tratam do tema e, sempre que citarmos Bolter (2013), indicaremos o correlato utilizado pelos demais autores como forma de padronização. 
com o ministério a fim de implementar um programa de habitação rural semelhante ao PHRRS ${ }^{42}$ em nível nacional", criando um grupo de trabalho para tal finalidade. O PSH-rural com abrangência nacional foi executado até 2005 e foi acessado por 9.410 famílias camponesas em todo o Brasil. O valor disponibilizado era de $\mathrm{R} \$ 7.500,00$ por família, sendo $\mathrm{R} \$ 4.500$ subsídio do Orçamento Geral da União (OGU) e R\$3.000 financiados através do FGTS (SILVA, 2014, p. 87).

Para acessar o PSH-Rural, os camponeses deveriam se organizar em torno de entidades privadas sem fins lucrativos, e foi nesta ocasião e para esta finalidade que foi fundada a Cooperhaf assim como outras entidades como a CRENNOR, COOHAF e CRESOL (BOLTER, 2013), conforme comentamos no $1^{\circ}$ capítulo.

Em 2003 o governo federal dá início ao Programa Nacional de Habitação Rural (PNHR), reunindo quatro linhas diferentes de acesso a recursos: o PSH-Rural na modalidade "leilão subsidiado", o CC-FGTS na modalidade "caução", CC-FGTS na modalidade "financiamento" e o Crédito Solidário-FDS na modalidade "financiamento" (SILVA, 2014, p. 88; ROVER; MUNARINI, 2010, p. 261). Os valores e condições gerais de acesso aos programas podem ser observados na Tabela 3. Segundo os autores, a principal dificuldade dos camponeses para acessar os programas era a capacidade de arcar com as contrapartidas financeiras exigidas e, além disso, de finalizar suas construções, tendo em vista que o recurso disponível era muito inferior ao necessário para a obra:

Para a maioria [dos camponeses], o volume de recursos disponibilizado pelo Programa, somado à sua contrapartida, não foi suficiente para realizar toda a obra. Muitos deles tiveram que complementar os recursos com vendas de bens da propriedade ou mesmo buscando empréstimo de familiares, amigos ou bancário (ROVER e MUNARINI, 2010, p. 265).

O PNHR funcionou conforme esta formatação até 2008. Em 2009 foi lançado o programa "Minha Casa, Minha Vida" (MCMV) pelo governo Lula, quando os programas habitacionais urbanos e rurais são reeditados e paulatinamente reconfigurados conforme novos moldes. A partir desta fase o PNHR é incorporado ao programa MCMV como um subprograma e, apesar de manter a mesma denominação, é totalmente modificado, passando a ter regras unificadas de acesso para famílias camponesas e povos originários, como veremos adiante.

No que diz respeito ao programa MCMV na sua totalidade (urbano e rural), há que se fazer destaque para os números apresentados como meta - 1 milhão de moradias para a primeira edição do programa, de 2009 ao final de 2011, e 2 milhões para a segunda, de 2012 a março de 2016 - e o inédito montante de subsídios para a produção habitacional direcionado à população de menor renda - que chegava muito perto dos 100\%. Criado pela Casa Civil da Presidência da República e à revelia do Plano Nacional de Habitação (o PlanHab, que vinha sendo arduamento constrúido pelo

\footnotetext{
${ }^{42}$ Conforme nota anterior, ler PHRRS como PSH-Rural.
} 
Ministério das Cidades a partir de consultas e conferências em todos os níveis dos entes federados), o programa MCMV foi uma das ações mais efetivas do governo em reação à crise econômica internacional que teve início no ano anterior.

Apesar do "ousado" montante de subsídios para a produção de habitação para as famílias com renda mensal de até três salários mínimos - como expressado por Baravelli (2014, p. 12) -, já no lançamento do programa a distrubuição das metas de produção de unidades para as modalidades cujo gerenciamento do recurso não estaria nas mãos de construtoras, mas sim de entidades organizadoras, era de pouco mais de 1\% - que correspondem às modalidades MCMV-Entidades e PNHR/MCMV.

A história do subsídio habitacional no Brasil é conhecida pela constante captura da subvenção pelas classes médias e agentes privados da produção imobiliária, ao invés de atender, na escala necessária, os trabalhadores que mais precisam. Embora essa tendência deva novamente prevalecer [a partir do programa MCMV], há que se considerar o interesse político e eleitoral do governo em atingir a base da pirâmide (ARANTES e FIX, 2009, p. 4).

O balanço das contratações do programa MCMV - fase 1 até final de 2009, na Tabela 2, ilustra com clareza esta ideia.

Tabela 2: Contratação por faixa de renda e modalidade do PMCMV 1 Fonte: modificado pela autora a partir de Baravelli (2014)

\begin{tabular}{lllll}
\hline Renda & Meta (UH) & Modalidade de contratação & Unidades & \% \\
\hline & & Repasse para habitação rural (PNHR) & 5.167 & 0,51 \\
\cline { 3 - 5 } & & Repasse para construtoras (FAR) & 404.407 & 40,23 \\
\cline { 3 - 5 } 0 a 3 s.m. & \multirow{2}{*}{400.000} & Subsídio pelo FGTS & 88.580 & 8,81 \\
\cline { 3 - 5 } & & Oferta pública em cidades até 50mil hab. & 63.772 & 6,34 \\
\cline { 3 - 5 } & & Repasse para entidades organizadoras (FDS) & 9.395 & 0,93 \\
\cline { 3 - 5 } & & Subtotal & $\mathbf{5 7 1 . 3 2 1}$ & $\mathbf{5 6 , 8 4}$ \\
\hline 3 a 6 s.m. & 400.000 & Financiamento pelo FGTS (3 a 6 s.m.) & 284.772 & 28,33 \\
\hline 6 a 10 s.m. & 200.000 & Financiamento pelo FGTS (6 a 10 s.m.) & 149.035 & 14,83 \\
\hline & & Total & $\mathbf{1 . 0 0 5 . 1 2 8}$ & $\mathbf{1 0 0 , 0 0}$ \\
\hline
\end{tabular}

Do ponto de vista da pauta de reivindicações dos movimentos sociais pela reforma urbana e segundo uma boa parcela dos estudos mais críticos que têm o programa MCMV como objeto (SANTOAMORE; SHIMBO; RUFINO, 2015; FERREIRA, 2012; CARDOSO, 2013), um dos maiores equívocos na concepção deste programa diz respeito à ausência da questão fundiária nas regulamentações do governo, quanto a produção urbana de habitações. Este fato, por si, já sugere a gravidade das consequências do programa na malha urbana das cidades brasileiras: esta nãoregulamentação dá autonomia ao mercado imobiliário nas decisões de preço e localização das terras a

\footnotetext{
43 Aqui o autor inclui o PNHR na faixa de renda de 0 a 3 salários mínimos mensais mas, como visto anteriormente, a definição da renda limite para o acesso ao PNHR é dada pela renda bruta familiar anual.
} 
serem ocupadas pelos empreendimentos, acirrando inevitavelmente processos perniciosos de segregação espacial ${ }^{44}$.

A ausência de regulamentação da questão fundiária também impacta sobre o próprio déficit habitacional, sendo que a eficiência na sua redução é recorrentemente utilizada nas propagandas do governo e mesmo nos trabalhos acadêmicos como argumento positivo para enaltecer as qualidades do programa MCMV. Porém, conforme apontado por Baravelli (2014),

Pensar que o déficit de moradias no Brasil se comporta como um 'primeiro motor' que põe em movimento o programa federal é investigar um 'falso problema', semelhante ao que Gabriel Bolaffi descreveu para a política habitacional baseada no antigo $\mathrm{BNH}$, que 'é formulada não a partir das características intrinsecas ao problema, mas a partir das necessidades da estratégia do poder" (Bolaffi, 1982: 40). (BARAVELLI, 2014, p. 105)

O autor demonstra que o impacto no déficit é, na realidade, o oposto do esperado. Isso porque a meta da produção de novas unidades, apontada como grande propósito do programa, unida ao repasse gigantesco de recursos a fundo perdido às construtoras e, principalmente, unida à desregulamentação da questão fundiária e da localização dos empreendimentos, ocasionou o inflacionamento dos preços de aluguel nas áreas mais bem localizadas, repercutindo assim no aumento do déficit habitacional devido ao fator "ônus excessivo por aluguel” (BARAVELLI, 2014, p. 105 e seguintes).

Se é o valor dos aluguéis que está impedindo a queda do déficit habitacional entre a população de baixa renda, então que papel nele pode desempenhar as metas físicas do programa MCMV? Embora possa aumentar em parte a oferta de imóveis para aluguel (contrariando regras de arrendamento da unidade habitacional da Caixa Econômica Federal), a construção das novas moradias pelo programa implica muito mais num aumento de demanda por terra urbana que, em última instância, sustenta a dinâmica imobiliária recente nas grandes e médias cidades brasileiras, de incessantes elevações de valor para compra e também aluguel de moradias (BARAVELLI, 2014, p. 112).

Certamente, portanto, o programa MCMV representa uma guinada na forma como os programas habitacionais estavam sendo executados até então, e o PNHR/MCMV não pode ser considerado fora deste contexto e deste processo - por menor que seja o impacto do número de unidades contratadas ao longo do período de operação do programa. Como veremos mais adiante, não é porque é relativamente pequena a quantidade de recursos ou unidades reservadas para o atendimento daqueles que não vivem nos médios e grandes centros urbanos que a demanda não existe - e este é um aspecto muito importante para este trabalho

\footnotetext{
44 A respeito deste tema, consultar Rodrigues (2013).
} 
A seguir vamos analisar as particularidades do PNHR/MCMV para compreendermos o alcance desta guinada no percurso dos programas de habitação para os camponeses.

\subsubsection{A versão não urbana do Minha Casa Minha Vida - o PNHR/MCMV}

Enquanto parte integrante do programa MCMV, o PNHR "tem a finalidade de subsidiar a aquisição ou reforma de moradia aos agricultores familiares e trabalhadores rurais" (BRASIL, 2009). O atual formato do PNHR é considerado pelos movimentos sociais e sindicais rurais uma grande conquista e fruto das suas lutas por moradia no campo e em outros contextos não urbanos ao longo dos anos.

Tabela 3: Valores destinados a habitação rural nos diferentes programas do Governo Federal Fonte: Elaboração própria a partir de Silva (2014), Rover; Munarini (2010) e Brasil (2016)

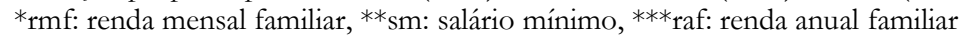

\begin{tabular}{|c|c|c|c|c|}
\hline período & programa & $\begin{array}{l}\text { renda limite para enquadram } \\
\text { dos agricultores }(\mathrm{R} \$)\end{array}$ & $\begin{array}{l}\text { valor disponível } \\
(\mathrm{R} \$)\end{array}$ & $\begin{array}{l}\text { contrap. / } \\
\text { financiam. }(\mathrm{R} \$)\end{array}$ \\
\hline $2002-2005$ & PSH-Rural & $740 \mathrm{rmf}^{*}$ & 7.500 & - \\
\hline \multirow[t]{4}{*}{$2003-2009$} & PSH-Rural & $465 \mathrm{rmf}^{*}$ & até 4.500 & - \\
\hline & CC-FGTS-caução & $1 \mathrm{sm}^{* *} \mathrm{rmf}^{*}$ & 8.000 & 2.093 \\
\hline & CC-FGTS-financiamento & $1.500 \mathrm{rmf}^{*}$ & 9.000 & 6.000 \\
\hline & Crédito Solidário & 3 salários mínimos rmf* & - & 10.000 \\
\hline \multirow[t]{3}{*}{2009 - atual } & PNHR G1 & $17.000 \mathrm{raf}^{* * *} 45$ & $34.200^{46}$ & 1.368 \\
\hline & $\mathrm{G} 2^{47}$ & $33.000 \mathrm{raf}^{* * *}$ & 37.600 & até 30.000 \\
\hline & G3 & $78.000 \mathrm{raf}^{* * *}$ & - & até 60.000 \\
\hline
\end{tabular}

O aumento considerável do subsídio em relação aos programas anteriores é um dos importantes motivos para esta comemoração. Como pudemos visualizar na Tabela 3, os valores dos programas habitacionais para o campo variaram significativamente ao longo dos anos, e o subsídio disponível para a atual versão do PNHR é quase sete vezes maior do que o disponibilizado no primeiro programa de abrangência nacional, no ano de 2003. As famílias que podem acessar o maior subsídio a fundo perdido são as que se enquadram no Grupo 1 - G1, cuja renda bruta familiar anual deve ter valor máximo de $\mathrm{R} \$ 17.000,00$. O programa atende também ao Grupo 2 - G2, para as

${ }^{45}$ Em meados de 2015 as regras para determinação do valor da Declaração de Aptidão ao Programa Nacional de Fortalecimento da Agricultura Familiar (DAP e PRONAF) (que é utilizada como referência para o enquadramento das famílias no PNHR, como será explicado a frente) foram modificadas, o que provocou sua elevação e o consequente desenquadramento indevido de diversos agricultores no acesso ao PNHR. Para mitigar este problema, a CEF provisoriamente negociou a utilização de um coeficiente de redução igual a 0,5876 que, multiplicado pelo valor da DAP, resultará nos valores para enquadramento no PNHR. Portanto, os valores limite de renda corrigidos por esse coeficiente da DAP no acesso ao programa, segundo a última Portaria (Portaria Interministerial no 97 de 30/03/2016) seriam de aproximadamente $\mathrm{R} \$ 28.931$ para o G1, $\mathrm{R} \$ 56.160$ para o G2 e $\mathrm{R} \$ 132.743$ para o $\mathrm{G} 3$.

46 Valor atualizado através da Portaria Interministerial no 97 de 30/03/2016.

47 Segundo informação fornecida via email pela Suhar/CEF à autora em 26/01/2017, os grupos de acesso G2 e G3 do PNHR estão no momento com contratações suspensas, motivo pelo qual não houve revisão de valores para construção das unidades habitacionais. Portanto, os valores disponíveis para a construção da unidade habitacional (subsídio e financiamento) aqui apresentados estão em conformidade com a portaria anterior (Portaria Interministerial n. 580 de 03/12/2012). 
famílias com renda bruta familiar anual até $\mathrm{R} \$ 33.000,00$ e o Grupo 3 - G3, para as famílias com renda bruta familiar anual de até $\mathrm{R} \$ 78.000,00$, com financiamentos a baixas taxas de juros.

Tabela 4: Distribuição do PNHR/MCMV

Fonte: elaboração da autora a partir de Rodriguez (2016) e Brasil (2016)

\begin{tabular}{|c|c|c|c|c|}
\hline & \multicolumn{2}{|c|}{ Grupo 1} & Grupo 2 & Grupo 3 \\
\hline \multicolumn{5}{|c|}{ Enquadramento } \\
\hline $\begin{array}{l}\text { renda bruta familiar } \\
\text { anual limite }\end{array}$ & \multicolumn{2}{|c|}{ Até $\mathrm{R} \$ 17.000,00$} & $\mathrm{R} \$ 17.000,01$ a $\mathrm{R} \$ 33.000,00$ & $\begin{array}{l}\mathrm{R} \$ 33.000,00 \mathrm{a} \mathrm{R} \$ \\
78.000,00\end{array}$ \\
\hline \multicolumn{5}{|c|}{ Recurso para edificação ou reforma } \\
\hline Região & $\mathrm{NE}, \mathrm{SE}, \mathrm{CO}$ e $\mathrm{S}$ & Norte & Todas as regiões & Todas as regiões \\
\hline Construção & $\mathrm{R} \$ 34.200,00$ & $\mathrm{R} \$ 36.600,00$ & \multirow{2}{*}{ Não há } & \multirow{2}{*}{ Não há } \\
\hline Reforma & $\mathrm{R} \$ 20.700,00$ & $\mathrm{R} \$ 22.100,00$ & & \\
\hline \multicolumn{5}{|c|}{ Subsídios e financiamentos } \\
\hline $\begin{array}{l}\text { Recursos destinados à } \\
\text { EO }\end{array}$ & \multicolumn{2}{|c|}{$\begin{array}{c}\mathrm{R} \$ 1.000,00 \text { Assistência Técnica }+\mathrm{R} \$ \\
\text { 700,00 Trabalho Social }\end{array}$} & $\begin{array}{c}\mathrm{R} \$ 1.000,00 \text { Assistência } \\
\text { Técnica + R\$ } 700,00 \\
\text { Trabalho Social }\end{array}$ & Não há \\
\hline Propostas & \multicolumn{2}{|c|}{ Via EO } & Via EO & Via EO ou individual \\
\hline $\begin{array}{l}\text { Contrapartida do } \\
\text { beneficiário }\end{array}$ & \multicolumn{2}{|c|}{$\begin{array}{l}\text { 4\% do valor subsídio, sem taxa e sem } \\
\text { atualização monetária, carência de } 1 \text { ano }\end{array}$} & $\begin{array}{l}\text { Não há informações } \\
\text { atualizadas }{ }^{48}\end{array}$ & $\begin{array}{c}\text { Não há informações } \\
\text { atualizadas }\end{array}$ \\
\hline Prestações e taxas & \multicolumn{2}{|c|}{$\begin{array}{c}\text { Quatro parcelas anuais, sem taxa de } \\
\text { juros }\end{array}$} & $\begin{array}{l}\text { Não há informações } \\
\text { atualizadas }\end{array}$ & $\begin{array}{l}\text { Não há informações } \\
\text { atualizadas }\end{array}$ \\
\hline prazo de amortização & \multicolumn{2}{|c|}{4 anos } & $\begin{array}{l}\text { Não há informações } \\
\text { atualizadas }\end{array}$ & $\begin{array}{l}\text { Não há informações } \\
\text { atualizadas }\end{array}$ \\
\hline \multicolumn{5}{|c|}{ Fonte de Recurso } \\
\hline & \multicolumn{2}{|c|}{ OGU } & FGTS & FGTS \\
\hline
\end{tabular}

A aferição da renda bruta familiar anual é realizada através da Declaração de Aptidão ao PRONAF (DAP), ou seja, através do mesmo mecanismo que alguns camponeses já utilizam para acessar os recursos do Programa Nacional de Fortalecimento da Agricultura Familiar. A DAP é elaborada a partir dos registros de comercialização dos produtos da família no seu bloco de notas, tanto de compras quanto de vendas, e se refere sempre ao período de um ano. O bloco de notas no meio rural funciona como controle fiscal de todas as atividades comerciais dos produtores agropecuários, e muitas vezes serve como comprovação de tempo de trabalho (ou "tempo de bloco", como costumam dizer os camponeses) para os pedidos de aposentadoria.

À semelhança da modalidade urbana Entidades do programa MCMV, as famílias que acessam o PNHR/MCMV através dos grupos G1 e G2 devem estar reunidas em torno de uma Entidade Organizadora (EO). Esta entidade pode ser uma associação de moradores, um sindicato, o poder público (como o município, por exemplo) ou outro tipo de organização sem fins lucrativos que

${ }^{48}$ Conforme indicado na nota de rodapé número 47, a portaria mais recente que regulamenta o PNHR e revisa seus valores e regras (Portaria Interministerial no 97) não apresenta informações específicas sobre as condições de acesso das famílias enquadradas nos grupos 2 e 3 , motivo pelo qual esta tabela não se encontra completa. 
represente as famílias que estão acessando o recurso. Estes grupos devem ser compostos de no mínimo 4 e no máximo 50 famílias. Até o início de 2016 estas EO não passavam por nenhum tipo de habilitação junto ao Ministério das Cidades; para acessar o PNHR, a EO deveria apenas enviar à Caixa Econômica Federal ou ao Banco do Brasil o contrato social, no qual deveria constar que é pessoa jurídica sem fins lucrativos, na forma de associação, fundações, cooperativa, sindicato ou entes públicos. Porém, desde julho de 2016, com a promulgação da Portaria $\mathrm{n}^{\circ} 178$ do Ministério das Cidades, as Entidades Organizadoras que pretendem acessar recursos do PNHR devem se habilitar também, submetendo-se a uma seleção mais rigorosa.

Atualmente, os valores disponibilizados para a construção de uma casa para as famílias que acessam o programa estão regulamentados pela Portaria Interministerial $n^{\circ} 97$ de 30/03/2016. Segundo esta, as famílias que se enquadram no grupo de acesso G1 tem direito ao valor de $\mathrm{R} \$ 34.200,00$. Deste montante, $96 \%$ correspondem ao subsídio do OGU e os outros 4\% devem ser devolvidos em 4 parcelas anuais de $\mathrm{R} \$ 342,00$, totalizando $\mathrm{R} \$ 1.368,00$. A família que acessa pelo G1 também pode optar reformar sua casa, e neste caso terá acesso a $\mathrm{R} \$ 20.700$ de subsídio. No formato inicial do programa não havia diferenciação de valores de subsídio conforme a região do país, mas a partir de dezembro de 2012 foi concedido valor diferenciado para a região Norte, justificado pelas dificuldades de transporte de materiais. Neste caso o valor do subsídio para o G1 ficou estabelecido em $\mathrm{R} \$ 36.600,00$ para construção e $\mathrm{R} \$ 22.100,00$ para reforma.

O PNHR também passa a centralizar o atendimento da produção habitacional para outros grupos não urbanos além dos camponeses quando - em consonância com a postura dos sindicatos rurais conforme vimos no $1^{\circ}$ capítulo - adota como público-alvo a categoria "Agricultores Familiares". Esta definição está, desde 2006, regulamentada pela Lei n. 11.326, que "estabelece as diretrizes para a formulação da Política Nacional da Agricultura Familiar e Empreendimentos Familiares Rurais". Interessa-nos ressaltar a definição encontrada no artigo $3^{\circ}$ desta Lei:

Art. 3o Para os efeitos desta Lei, considera-se agricultor familiar e empreendedor familiar rural aquele que pratica atividades no meio rural, atendendo, simultaneamente aos seguintes requisitos:

I - não detenha, a qualquer título, área maior do que 4 (quatro) módulos fiscais;

II - utilize predominantemente mão-de-obra da própria família nas atividades econômicas do seu estabelecimento ou empreendimento;

III - tenha percentual mínimo da renda familiar originada de atividades econômicas do seu estabelecimento ou empreendimento, na forma definida pelo Poder Executivo;

IV - dirija seu estabelecimento ou empreendimento com sua família (BRASIL, 2006)

O parágrafo $2^{\circ}$ desse artigo complementa: 
$\int 2^{\circ}$ São também beneficiários desta Lei:

I - silvicultores que atendam simultaneamente a todos os requisitos de que trata o caput deste artigo, cultivem florestas nativas ou exóticas e que promovam o manejo sustentável daqueles ambientes;

II - aqüicultores que atendam simultaneamente a todos os requisitos de que trata o caput deste artigo e explorem reservatórios hídricos com superfície total de até $2 \mathrm{ha}$ (dois hectares) ou ocupem até $500 \mathrm{~m}^{3}$ (quinhentos metros cúbicos) de água, quando a exploração se efetivar em tanques-rede;

III - extrativistas que atendam simultaneamente aos requisitos previstos nos incisos II, III e IV do caput deste artigo e exerçam essa atividade artesanalmente no meio rural, excluídos os garimpeiros e faiscadores;

IV - pescadores que atendam simultaneamente aos requisitos previstos nos incisos I, II, III e IV do caput deste artigo e exerçam a atividade pesqueira artesanalmente;

$\mathrm{V}$ - povos indígenas que atendam simultaneamente aos requisitos previstos nos incisos II, III e IV do caput do art. 30;

VI - integrantes de comunidades remanescentes de quilombos rurais e demais povos e comunidades tradicionais que atendam simultaneamente aos incisos II, III e IV do caput do art. 3० (BRASIL, 2006, grifos nossos).

Portanto, além dos camponeses assentados e proprietários, estariam sendo incluídos no rol de possíveis beneficiários todas as populações que não habitam os núcleos urbanos de maneira geral: extrativistas, silvicultores, pescadores, indígenas, quilombolas, etc.

Ao total foram contratadas, em todo o país desde o início do programa até dezembro de 2016, 172.273 unidades tanto para construção quanto para reforma; este número corresponde a um atendimento de 3,94\% dos estabelecimentos da agricultura familiar ${ }^{49}$ no país. Na Tabela 5 abaixo podemos verificar a distribuição das unidades construídas ou reformadas pelo PNHR pelas regiões e estados. Quando observada a proporção entre unidades produzidas e o número de estabelecimentos da agricultura familiar existentes, podemos ter uma noção mais concreta do impacto do programa em cada estado. É significativo verificar, por exemplo, que no Amapá, que possui pouco mais que 2.800 estabelecimentos da agricultura familiar, 13,52\% destes acessaram os recursos do PNHR para reformar ou construir suas casas. Sergipe segue na mesma proporção, seguido de Rondônia com 9,30\% e de Santa Catarina com 8,84\% dos estabelecimentos da agricultura familiar acessando estes subsídios.

\footnotetext{
49 este índice, assim como os seguintes, são originados da relação entre o Censo Agropecuário de 2006 e os dados de produção do PNHR de 2016. Alertamos para possíveis inconsistências, em primeiro lugar, devido à diferença de datas, considerando que os levantamentos possuem 10 anos de diferença entre si. Em segundo lugar, devido a utilização do levantamento do IBGE, o Censo Agropecuário, que leva em consideração a unidade econômica como critério (um estabelecimento familiar), e não o levantamento do INCRA, que leva em consideração a unidade fundiária (propriedade de um imóvel). É recorrente que um único imóvel possua em sua matrícula dois ou mais estabelecimentos familiares, o que modificaria substancialmente os índices apresentados nesta tabela. Apontamos também que, para este estudo, seria mais coerente a utilização dos dados do INCRA - que possuem como referência a unidade fundiária -, o que não ocorreu por dificuldade de acesso a estes dados.
} 
Apesar de apresentar um número muito alto de contratos do PNHR, a região Nordeste apresenta também um altíssimo número de estabelecimentos da agricultura familiar (50,07\% do total, praticamente metade dos estabelecimentos existentes no país), fazendo com que proporcionalmente o número de contratos apresente um impacto relativamente baixo. Apesar de ser relevante observar que o número de contratos realizados (68.324) corresponde a 11,77\% do déficit habitacional rural do Nordeste brasileiro (FJP, 2014), também é necessário prevenir que não há uma relação direta entre produção habitacional do PNHR e déficit habitacional rural, conforme trataremos a frente.

Tabela 5: relação entre produção do PNHR e número de estabelecimentos da agricultura familiar por estados e regiões Fonte: Elaboração própria a partir de IBGE, 2006 e CEF, 2016.

\begin{tabular}{|c|c|c|c|c|}
\hline REGIÃO & UF & $\begin{array}{l}\text { Unidades } \\
\text { PNHR (a) }\end{array}$ & $\begin{array}{c}\text { Estab. da } \\
\text { agricultura } \\
\text { familiar (b) }\end{array}$ & $a / b$ \\
\hline BRASIL & & 172.273 & 4.367 .902 & $3,94 \%$ \\
\hline \multirow{8}{*}{ NORTE } & & 21.358 & 413.101 & $5,17 \%$ \\
\hline & Rondônia & 7.000 & 75.251 & $9,30 \%$ \\
\hline & Acre & 1.111 & 25.187 & $4,41 \%$ \\
\hline & Amazonas & 3.995 & 61.843 & $6,46 \%$ \\
\hline & Roraima & 583 & 8.908 & $6,54 \%$ \\
\hline & Pará & 7.904 & 196.150 & $4,03 \%$ \\
\hline & Amapá & 387 & 2.863 & $13,52 \%$ \\
\hline & Tocantins & 378 & 42.899 & $0,88 \%$ \\
\hline \multirow{10}{*}{ NORDESTE } & & 68.324 & 2.187.295 & $3,12 \%$ \\
\hline & Maranhão & 18.808 & 262.089 & $7,18 \%$ \\
\hline & Piauí & 7.703 & 220.757 & $3,49 \%$ \\
\hline & Ceará & 4.311 & 341.510 & $1,26 \%$ \\
\hline & Rio Gde do Norte & 4.598 & 71.210 & $6,46 \%$ \\
\hline & Paraíba & 2.794 & 148.077 & $1,89 \%$ \\
\hline & Pernambuco & 7.016 & 275.740 & $2,54 \%$ \\
\hline & Alagoas & 2.370 & 111.751 & $2,12 \%$ \\
\hline & Sergipe & 12.426 & 90.330 & $13,76 \%$ \\
\hline & Bahia & 8.298 & 665.831 & $1,25 \%$ \\
\hline \multirow{5}{*}{ SUDESTE } & & 23.640 & 699.978 & $3,38 \%$ \\
\hline & Minas Gerais & 15.465 & 437.415 & $3,54 \%$ \\
\hline & Espírito Santo & 3.390 & 67.403 & $5,03 \%$ \\
\hline & Rio de Janeiro & 207 & 44.145 & $0,47 \%$ \\
\hline & São Paulo & 4.578 & 151.015 & $3,03 \%$ \\
\hline \multirow{4}{*}{ SUL } & & 51.638 & 849.997 & $6,08 \%$ \\
\hline & Paraná & 12.235 & 302.907 & $4,04 \%$ \\
\hline & Santa Catarina & 14.906 & 168.544 & $8,84 \%$ \\
\hline & Rio Gde. do Sul & 24.497 & 378.546 & $6,47 \%$ \\
\hline \multirow[t]{5}{*}{ CENTROESTE } & & 7.313 & 220.531 & $3,32 \%$ \\
\hline & Mato G. Sul & 2.286 & 44.104 & $5,18 \%$ \\
\hline & Mato Grosso & 1039 & 86.167 & $1,21 \%$ \\
\hline & Goiás & 3.908 & 88.436 & $4,42 \%$ \\
\hline & D.F. & 80 & 1.824 & $4,39 \%$ \\
\hline
\end{tabular}


Um levantamento considerando as três fases do programa MCMV mostra que na $2^{\mathrm{a}}$ fase, entre 2012 e março de 2016, foram realizados quase 80\% dos contratos do PNHR/MCMV, conforme pode ser observado na Tabela 6 .

Tabela 6: produção nacional do PNHR por fases do programa MCMV até dezembro de 2016

\begin{tabular}{|c|c|c|c|c|c|c|c|}
\hline \multirow[t]{2}{*}{ U.T. } & \multirow[t]{2}{*}{ GRUPO } & \multicolumn{6}{|c|}{ UNIDADES } \\
\hline & & \multicolumn{2}{|c|}{ total } & \multicolumn{2}{|c|}{ construções } & \multicolumn{2}{|c|}{ reformas } \\
\hline \multirow{4}{*}{$\begin{array}{c}1^{\mathbf{a}} \text { fase } \\
2009-2011\end{array}$} & GI & 17.430 & $91,50 \%$ & 17.253 & $95,51 \%$ & 177 & $17,99 \%$ \\
\hline & GII & 1.600 & $8,40 \%$ & 796 & $4,41 \%$ & 804 & $81,71 \%$ \\
\hline & GIII & 19 & $0,10 \%$ & 16 & $0,09 \%$ & 3 & $0,30 \%$ \\
\hline & TOTAL & 19.049 & & 18.065 & & 984 & \\
\hline \multirow{4}{*}{$\begin{array}{c}2^{\mathbf{a}} \text { fase } \\
2012- \\
\text { mar } 2016\end{array}$} & GI & 134.385 & $98,72 \%$ & 128.925 & $99,68 \%$ & 5.460 & $80,55 \%$ \\
\hline & GII & 1.672 & $1,23 \%$ & 358 & $0,28 \%$ & 1.314 & $19,39 \%$ \\
\hline & GIII & 64 & $0,05 \%$ & 60 & $0,05 \%$ & 4 & $0,06 \%$ \\
\hline & TOTAL & 136.121 & & 129.343 & & 6.778 & \\
\hline \multirow{6}{*}{$\begin{array}{c}3^{\text {a }} \text { fase } \\
\text { mar } 2016- \\
\text { dez } 2016\end{array}$} & GI & & $100,00 \%$ & 16285 & $100,00 \%$ & 818 & $100,00 \%$ \\
\hline & & 17.103 & & & & & \\
\hline & GII & 0 & $0,00 \%$ & 0 & $0,00 \%$ & 0 & $0,00 \%$ \\
\hline & GIII & 0 & $0,00 \%$ & 0 & $0,00 \%$ & 0 & $0,00 \%$ \\
\hline & TOTAL & & & & & & \\
\hline & & 17.103 & & 16.285 & & 818 & \\
\hline TOTAL & & 172.273 & & 163.693 & $95,02 \%$ & 8.580 & $4,98 \%$ \\
\hline
\end{tabular}

O grupo de acesso GI é o que apresenta maior número de unidades contratadas, abrangendo 98,1\% do total (168.918 unidades). O GII possui 1,9\% (3.272 unidades), e o grupo GIII não chega a atingir $0,1 \%$ das unidades contratadas ( 83 unidades).

Gráfico 1: produção nacional do PNHR, proporções entre unidades construídas e reformadas por grupo de acesso Fonte: Elaboração própria a partir de CEF (2016)

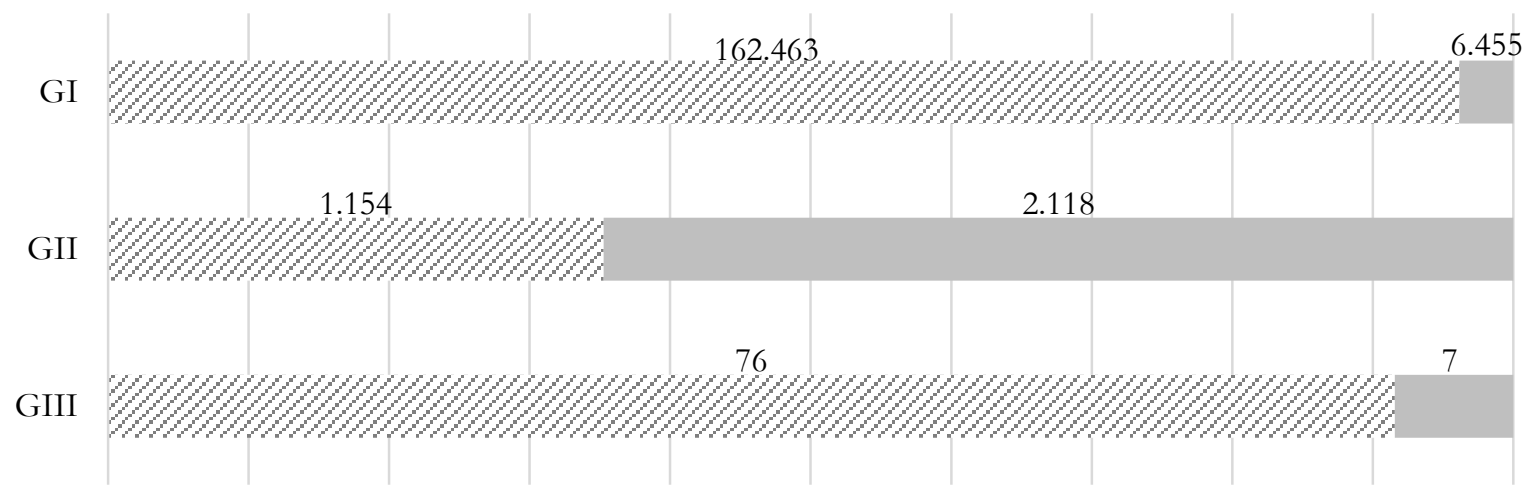

Quanto à proporção entre quantidade de unidades construídas e reformadas, o Gráfico 1 apresenta esta informação a partir de cada grupo de acesso. No G1, que concentra mais de 98\% dos contratos do PNHR, a proporção de construções sobre reformas é de 96\%. Já no G2 esta fração se 
inverte, apresentando um predomínio das reformas sobre as construções na proporção de $68 \%$. No G3 a alta proporção de construções sobre reformas volta a se repetir, com a predominância em 91\% dos contratos.

A região com maior produção do PNHR é a região Nordeste, com 68.324 unidades, seguida pela região Sul com 51.638 unidades, em terceiro lugar a região Sudeste com 23.640 unidades, em quarto a região Norte com 21.358 unidades e em último lugar a região Centro-oeste, com 7.313 unidades construídas. O predomínio do grupo de acesso GI é generalizado para todas regiões do país.

Tabela 7: Produção do PNHR no Brasil por regiões e grupo de acesso até dezembro de 2016 Fonte: Elaboração própria a partir de CEF (2016)

\begin{tabular}{|c|c|c|c|c|c|c|c|}
\hline \multirow{2}{*}{ U.T. } & \multirow[t]{2}{*}{ GRUPO } & \multicolumn{6}{|c|}{ UNIDADES } \\
\hline & & \multicolumn{2}{|l|}{ total } & \multicolumn{2}{|c|}{ construções } & \multicolumn{2}{|c|}{ reformas } \\
\hline \multirow{4}{*}{ BRASIL } & GI & 168.918 & $98,1 \%$ & 162.463 & $99,2 \%$ & 6.455 & $75,2 \%$ \\
\hline & GII & 3.272 & $1,9 \%$ & 1.154 & $0,7 \%$ & 2.118 & $24,7 \%$ \\
\hline & GIII & 83 & $0,0 \%$ & 76 & $0,0 \%$ & 7 & $0,1 \%$ \\
\hline & TOTAL & 172.273 & & 163.693 & $95,0 \%$ & 8.580 & $5,0 \%$ \\
\hline \multirow{4}{*}{$\begin{array}{l}\text { REGIÃO } \\
\text { SUL }\end{array}$} & GI & 48.572 & $94,1 \%$ & 43.808 & $97,4 \%$ & 4.764 & $71,4 \%$ \\
\hline & GII & 2.986 & $5,8 \%$ & 1.088 & $2,4 \%$ & 1.898 & $28,5 \%$ \\
\hline & GIII & 80 & $0,2 \%$ & 73 & $0,2 \%$ & 7 & $0,1 \%$ \\
\hline & TOTAL & 51.638 & & 44.969 & $87,1 \%$ & 6.669 & $12,9 \%$ \\
\hline \multirow{4}{*}{$\begin{array}{l}\text { REGIÃO } \\
\text { SUDESTE }\end{array}$} & GI & 23.635 & $100,0 \%$ & 23.441 & $100,0 \%$ & 194 & $98,0 \%$ \\
\hline & GII & 4 & $0,0 \%$ & 0 & $0,0 \%$ & 4 & $2,0 \%$ \\
\hline & GIII & 1 & $0,0 \%$ & 1 & $0,0 \%$ & 0 & $0,0 \%$ \\
\hline & TOTAL & 23.640 & & 23.442 & $99,2 \%$ & 198 & $0,8 \%$ \\
\hline \multirow{4}{*}{$\begin{array}{c}\text { REGIÃO } \\
\text { CENTROESTE }\end{array}$} & GI & 7.034 & $96,2 \%$ & 6.443 & $99,0 \%$ & 591 & $73,2 \%$ \\
\hline & GII & 277 & $3,8 \%$ & 61 & $0,9 \%$ & 216 & $26,8 \%$ \\
\hline & GIII & 2 & $0,0 \%$ & 2 & $0,0 \%$ & 0 & $0,0 \%$ \\
\hline & TOTAL & 7.313 & & 6.506 & $89,0 \%$ & 807 & $11,0 \%$ \\
\hline \multirow{4}{*}{$\begin{array}{c}\text { REGIÃO } \\
\text { NORDESTE }\end{array}$} & GI & 68.324 & $100,0 \%$ & 67.589 & $100,0 \%$ & 735 & $100,0 \%$ \\
\hline & GII & 0 & $0,0 \%$ & 0 & $0,0 \%$ & 0 & $0,0 \%$ \\
\hline & GIII & 0 & $0,0 \%$ & 0 & $0,0 \%$ & 0 & $0,0 \%$ \\
\hline & TOTAL & 68.324 & & 67.589 & $98,9 \%$ & 735 & $1,1 \%$ \\
\hline \multirow{4}{*}{$\begin{array}{l}\text { REGIÃO } \\
\text { NORTE }\end{array}$} & GI & 21.353 & $100,0 \%$ & 21.182 & $100,0 \%$ & 171 & $100,0 \%$ \\
\hline & GII & 5 & $0,0 \%$ & 5 & $0,0 \%$ & 0 & $0,0 \%$ \\
\hline & GIII & 0 & $0,0 \%$ & 0 & $0,0 \%$ & 0 & $0,0 \%$ \\
\hline & TOTAL & 21.358 & & 21.187 & $99,2 \%$ & 171 & $0,8 \%$ \\
\hline
\end{tabular}

Da totalidade de 168.918 unidades construídas ou reformadas pelo PNHR/MCMV - GI em todo o Brasil até dezembro de 2016, a região Sul é responsável por 28,3\% (48.572 unidades).

Das 51.638 unidades contratadas pelo PNHR em SC, 87,1\%, ou seja, 44.969 unidades, são referentes à modalidade "construção", e apenas 12,9\%, 6.669, são da modalidade "reformas". Esse número de reformas executadas na região Sul - que em comparação com o número de construções 
parece irrelevante - vai chamar a atenção quando comparado a totalidade realizada no país: a região Sul é responsável por $77,7 \%$ das unidades concluídas/reformadas/ampliadas no país, um total de 6.669 unidades, das 8.580 concluídas/reformadas/ampliadas em todo o país.

Conforme vimos anteriormente, o debate sobre um programa como o MCMV, tratado com a magnitude de uma política habitacional para áreas urbanas, envolve temas importantes como a localização dos empreendimentos em relação a malha urbana, acesso a equipamentos públicos, oscilação do e interferência no preço da terra, a colaboração no desenvolvimento econômico da região através da geração de empregos, a mobilidade entre residência e trabalho, entre outros. Porém, é importante entendermos que muitos destes temas não fazem sentido no debate sobre a produção da habitação camponesa ${ }^{50}$. Desse modo, propomos aqui discutir cinco temas que consideramos fundamentais para este debate, tendo em vista nossas observações no trabalho de campo e frente aos aspectos do PNHR: 1) a questão fundiária no PNHR/MCMV; 2) a DAP (Declaração de Aptidão ao PRONAF) como critério de enquadramento das famílias; 3) o rebaixamento dos valores em relação ao MCMV nas cidades; 4) déficit habitacional rural versus produção do PNHR/MCMV; e 5) a inadequação do regime de construção sob o PNHR ao modo de vida camponês.

Não iremos comentar quanto a inadequação do projeto arquitetônico das habitações rurais por não fazer parte do escopo deste trabalho, o que não significa que não consideramos este um assunto também fundamental neste debate ${ }^{51}$.

\subsubsection{A questão fundiária no PNHR/MCMV}

Diferentemente do MCMV nas cidades, na modalidade rural do programa a questão do preço da terra não está em jogo, pelo menos num primeiro momento. Isso porque o programa pressupõe que todos os beneficiários que irão construir suas casas com o recurso federal sejam também legítimos proprietários de seu sítio ${ }^{52}$. O programa não oferece nenhum tipo de auxílio para a compra de terras, não interferindo, portanto, em qualquer dinâmica ou debate diretamente relacionado à reforma agrária. A portaria $\mathrm{n}^{\circ} 194$, de 30 de abril de 2013, admite que posseiros de terras públicas, ocupantes de terras particulares com direitos sucessórios pendentes de partilha e posseiros de boa fé ocupantes de terras particulares

50 Não iremos tratar neste trabalho das ramificações do PNHR para comunidades tradicionais - indígenas, quilombolas, extrativistas, seringueiros, ribeirinhos etc. Permaneceremos apenas no debate sobre o campesinato e a forma de habitar camponesa.

${ }^{51}$ Sobre este tema, consultar Carvalho, de Paula \& Pereira (2015).

${ }^{52}$ Exceto para os assentados pelo Plano Nacional de Reforma Agrária, que têm direito de acesso ao recurso do PNHR desde 2013 e cuja condição em relação à terra é aferida pelo INCRA através da Relação de Beneficiários homologada. 
também possam acessar o recurso para a construção ou reforma da casa. Esta, porém, é uma prática que não se tem efetivado devido a complexidade burocrática envolvida (informação verbal ${ }^{53}$ ). Poderíamos inicialmente entender a exigência da propriedade da parcela de terra como procedente, se consideramos que o programa é justamente direcionado para camponeses, ou seja, trabalhadores que já têm a lida com a terra como profissão e, por esse motivo já disponibilizam desta parcela. Porém, devemos lembrar que no Brasil a posse da terra - em outras palavras, a disponibilidade da parcela para nela trabalhar -, é diferente da sua propriedade - ou seja, a disponibilidade de um documento juridicamente reconhecido, que comprove o direito de propriedade sobre uma parcela de terra perante as instâncias públicas e privadas. O que não está sendo considerado pelas normativas do programa, portanto, é a realidade da estrutura fundiária do país, a qual reserva aos camponeses posseiros unicamente a condição de ilegalidade a partir de um histórico esquema de legitimação irregular de propriedade de terras por latifundiários, cartórios e governos locais, que acontece desde a promulgação da Lei de Terras em 1850 - e que tem sido denunciado por movimentos camponeses desde o final do século XIX, como vimos no $1^{\circ}$ capítulo ${ }^{54}$.

Portanto, apesar de num primeiro momento as regras do programa darem a entender que não interferem na questão da propriedade da terra, esse passa a ser um ponto crucial para entendermos o PNHR/MCMV uma vez que atende exclusivamente a quem a tem. A ausência de trato da questão da propriedade privada da terra no contexto do PNHR é sintoma de um debate incompleto, num país com a concentração fundiária que o Brasil apresenta - uma vez que se trata de um requisito eliminatório para o acesso ao recurso público destinado à provisão habitacional. Se, por um lado, tal ausência pode ser interpretada como uma omissão frente à questão fundiária brasileira, por outro lado parece eloquente o fato de os dados comprovarem uma alta proporção de camponeses proprietários principalmente nos estados da região Sul e Sudeste - como pode ser conferido na Tabela 8. Cabe lembrarmos, conforme estudado no $1^{\circ}$ capítulo, que as lideranças do sul do país sempre estiveram à frente dos sindicatos dos agricultores familiares a nível nacional e que o papel dessas lideranças foi definitivo na concepção, regulamentação e viabilização dos programas habitacionais para os camponeses, inclusive o PNHR. E é muito significativo que Santa Catarina apresente quase $90 \%$ dos estabelecimentos camponeses na condição de proprietários. Apesar de se fazer necessário uma pesquisa mais aprofundada a este respeito, é possível inferirmos que a concepção destes programas acabou sendo sistematicamente influenciada pela realidade conhecida destes dirigentes sindicais e pelos interesses da base por eles representada. Os estados do Nordeste, apesar de apresentarem uma alta proporção de estabelecimentos organizados em bases camponesas, agregam um contingente proporcionalmente menor de camponeses proprietários da terra que

\footnotetext{
${ }^{53}$ Informante 7 em entrevista à autora setembro de 2015.

54 Ainda sobre este tema, ver Oliveira (2007), Martins (1994) e outros.
} 
cultivam. Assim, por pressuposição lógica, os camponeses de estados como o Maranhão, o Ceará e o Piauí, ou mesmo Acre, Amazônia e Pará, objetivamente apresentam menor chance de acesso ao PNHR.

Tabela 8: Famílias camponesas proprietárias de terra que cultivam no Brasil e por UF (\%) Fonte: Censo Agropecuário 2006

\begin{tabular}{|c|c|c|c|c|c|c|c|c|c|c|c|c|c|c|}
\hline \multicolumn{15}{|c|}{ BRASIL $=74$} \\
\hline \multirow{7}{*}{$\begin{array}{l}\text { II } \\
\text { 孚 } \\
0 \\
0 \\
\text { Z }\end{array}$} & $\mathrm{RO}$ & 90 & \multirow{9}{*}{ 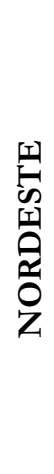 } & MA & 40 & \multirow{4}{*}{$\begin{array}{l}1 \\
\infty \\
5 \\
5 \\
0 \\
0\end{array}$} & MG & 85 & \multirow{3}{*}{ 号 } & PR & 79 & \multirow{4}{*}{ 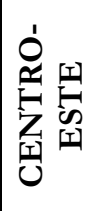 } & MS & 68 \\
\hline & $\mathrm{AC}$ & 66 & & PI & 53 & & ES & 89 & & SC & 88 & & MT & 75 \\
\hline & $\mathrm{AM}$ & 59 & & $\mathrm{CE}$ & 48 & & RJ & 76 & & RS & 84 & & GO & 84 \\
\hline & RR & 86 & & $\mathrm{RN}$ & 66 & & SP & 82 & & & & & DF & 55 \\
\hline & PA & 76 & & PA & 69 & & & & & & & & & \\
\hline & AP & 61 & & PE & 73 & & & & & & & & & \\
\hline & TO & 85 & & $\mathrm{AL}$ & 71 & & & & & & & & & \\
\hline & & & & SE & 87 & & & & & & & & & \\
\hline & & & & $\mathrm{BA}$ & 87 & & & & & & & & & \\
\hline
\end{tabular}

Apesar de todas estas dificuldades e restrições no acesso ao PNHR, ainda assim algumas famílias de arrendatários, para se esquivarem da obrigatoriedade de comprovação da titularidade na propriedade da terra e lograr o acesso ao recurso, negociam com o arrendador um título de propriedade referente apenas à pequena parcela ocupada pela família - ou seja, um título falso, porém aceito legalmente - para que dessa forma ela possa apresentar o documento de propriedade e assim dar entrada no pedido do recurso habitacional. A benfeitoria fica na terra e o arrendador posteriormente terá acesso a este bem - o que lhe convém - e família arrendatária usufrui da habitação até deixar a terra - arcando com o ônus de perder o direito de um novo acesso a um recurso do governo para fins habitacionais ${ }^{55}$.

A localização das unidades habitacionais a serem construídas através do PNHR não é, portanto, uma questão a ser enfrentada, uma vez que as casas serão construídas na propriedade préexistente. É importante destacar, no entanto, que isso não significa que este é um dado irrelevante no contexto da produção camponesa: pelo contrário, um dos grandes problemas enfrentados pelos pequenos produtores de alimentos é exatamente o escoamento da produção, que depende totalmente da localização de suas propriedades em relação aos núcleos consumidores e em relação à rede de acessos de melhor ou pior qualidade. Muitas vezes a localização do sítio é o fator que mais influencia na decisão quanto ao tipo de produção agropecuária que a família irá adotar. Este fato foi testemunhado objetivamente em nosso trabalho de campo: em um dos municípios visitados os

55 A informação sobre essa prática é resultado do cruzamento entre relatos de famílias entrevistadas, conversas informais com dirigentes sindicais, assessores técnicos e gestores públicos. Trata-se de uma prática ilegal, conhecida por muitos, mas sistematicamente velada - tanto pelas famílias de arrendatários como pelos arrendadores, agentes promotores e gestores do programa. 
camponeses não podiam produzir verduras, pois a estrada que seria utilizada para o escoamento da produção para o núcleo consumidor mais próximo era de terra. Devido à distância e à precariedade dos acessos a viagem se tornaria muito longa, o que causaria a eventual perda da produção no trajeto.

De todo modo e apesar das evidentes incongruências entre a realidade camponesa e as regras do programa de provisão habitacional, a própria estrutura do PNHR, limitada por uma concepção digamos - essencialmente 'urbana' de propriedade do solo, não abre brechas para um debate mais amplo sobre o território ocupado pelo campesinato.

Um ponto que também precisa ser estudado, também relacionado à questão fundiária, é aquele que trata da valorização da propriedade camponesa após o acesso ao PNHR. A construção de uma casa nova ou a reforma da casa já existente, numa pequena propriedade rural, certamente realiza um impacto positivo no seu valor de mercado e, provavelmente, irá interferir na dinâmica imobiliária das áreas rurais dos municípios brasileiros. Embora o estudo a respeito da influência dos investimentos do PNHR sobre a dinâmica imobiliária nas áreas rurais não seja objeto da presente pesquisa, certamente consiste em interessante aspecto para estudos futuros.

\subsubsection{A DAP como critério de enquadramento das familias}

A utilização da Declaração de Aptidão ao Pronaf como referência de faixa de renda para o enquadramento das famílias no PNHR é elogiada por alguns pesquisadores devido à relativa eficiência que o procedimento traz no processo de admissão no programa, já que mantem o mesmo procedimento do Pronaf:

O PMCMV Rural estabelece as categorias de agricultores beneficiários conforme as regras do PRONAF. Isso agiliza processos e aproveita uma sistemática consolidada há anos para distribuição das categorias de agricultores entre os grupos de contratação do programa (SILVA, 2014, p. 95).

Como esclarecido anteriormente, o valor final da renda que referencia o lançamento na DAP corresponde ao somatório das entradas registradas no bloco de notas do agricultor que, ao final do período de um ano, demonstra o rendimento bruto familiar anual. Porém, a renda registrada na DAP leva apenas em consideração os ganhos aferidos pela família, sem considerar as despesas que foram realizadas ao longo daquele ano - sejam elas da natureza que for. Este dado é relevante pois, em alguns tipos de cultivo - particularmente os oriundos dos sistemas de integração ${ }^{56}$ ou de fomento de empresas privadas (suinocultura, fumicultura, celulose) - os gastos necessários para instalação da produção - principalmente para a compra dos equipamentos exigidos pelas empresas - são

\footnotetext{
${ }^{56}$ conforme explicado na nota de rodapé 29 , página 36.
} 
geralmente bastante altos. Portanto, se por um lado, o ganho monetário bruto final, quando da venda da produção, envolve valores altos - o que faz subir o valor final da DAP da família - por outro lado também são altos os investimentos para viabilizar a realização do produto, resultando, num balanço geral, em um baixo retorno financeiro para o agricultor.

Nestes casos, a renda registrada na DAP desses agricultores é frequentemente alta, mas suas condições de vida costumam ser piores do que a dos agricultores não integrados, por exemplo. Configura-se assim uma situação no mínimo paradoxal: estes agricultores que, pelas condições reais de existência deveriam ter prioridade nos programas de habitação - e que possivelmente, inclusive, estariam enquadrados no déficit habitacional rural, conforme veremos à frente - não podem acessálos, pois sua renda extrapola o limite permitido pela normativa. Isso torna a DAP uma referência inconsistente para a determinação da real condição financeira das famílias e como critério para enquadramento ou não no acesso ao recurso habitacional.

Outra situação crítica, também resultado da adoção do valor de renda registrado na DAP como referência para acesso ao PNHR/MCMV, é aquela criada com os grupos que acabam submetidos a grandes atrasos no processo que antecede a contratação do financiamento - por exemplo, devido à espera para completar o número mínimo de famílias para fechar um grupo ou ao tempo dispendido com a resolução de trâmites burocráticos. Muitas vezes, ao longo dessa espera a realidade financeira da família acaba se transformando. Por exemplo, se a safra daquele ano resulta excelente (o que pode refletir uma situação conjuntural e não estrutural), ou se infortunadamente aparece a necessidade de tomar um empréstimo no banco (o que gera uma entrada e gastos que não correspondem a ganho efetivo da família) etc. Nestes casos, quando da formação do grupo o agricultor possuía, segundo a DAP, uma renda que permitia seu enquadramento, quando da contratação do financiamento a renda aparece falsamente majorada e a família é desenquadrada, ficando fora do programa.

\subsubsection{O rebaixamento dos valores em relação ao MCMV nas cidades}

Como vimos anteriormente, a ordem de grandeza do montante de recursos que o programa MCMV disponibilizou para a produção habitacional camponesa foi inédita. Agregado a este fato, também era uma boa novidade a diretriz que determinava que $96 \%$ deste valor poderia ser entregue a fundo perdido. Tais decisões e expedientes configuraram-se então como um dos principais motivos para que o advento do PNHR/MCMV fosse considerado uma conquista a ser comemorada por muitos movimentos sociais do campo. Esta diferença de valor entre os programas anteriores e o atual é tão significativa que muitos movimentos têm reivindicado o direto de acesso a este recurso também 
para os camponeses que já acessaram financiamentos habitacionais anteriormente ${ }^{57}$. Os movimentos alegam que os valores dos programas disponíveis anteriormente eram insuficientes para a construção de uma casa e que, por isso, estas famílias deveriam ter direito a acessar ao menos os recursos da modalidade Reforma do PNHR/MCMV. Pelas regras do programa, contudo, tanto no campo quanto na cidade, as famílias que já acessaram anteriormente benefícios do governo para fins habitacionais (seja para compra de materiais de construção, aquisição de imóveis etc.) ficam registradas no CADMUT, o Cadastro Nacional de Mutuários, e não podem acessar qualquer recurso para fins habitacionais novamente.

Ainda assim, apesar de se tratar de um montante nunca antes visto para a provisão habitacional camponesa, este subsídio ainda é significativamente defasado em relação aos valores disponibilizados para o meio urbano - e é muito importante procurar entender os motivos disso. Para possibilitar a comparação entre ambos, sugerimos utilizar como parâmetro a modalidade que, sob certos aspectos, é o correlato do PNHR nas cidades, o MCMV-Entidades, já que ambos se assemelham em relação a faixa de renda das famílias e o formato da organização da população para a qual está direcionado.

Diferentemente do PNHR, o montante de recurso para a construção de unidades habitacionais no programa MCMV urbano é estratificado de acordo com três critérios: a região ou unidade da federação em que se localiza; se a unidade construída será casa ou apartamento; e o porte do município. A Tabela 6 apresenta os valores do MCMV-Entidades vigentes até 2016 para a construção de casas na região Sul e estados do Espírito Santo e Minas Gerais, de acordo com o porte do município.

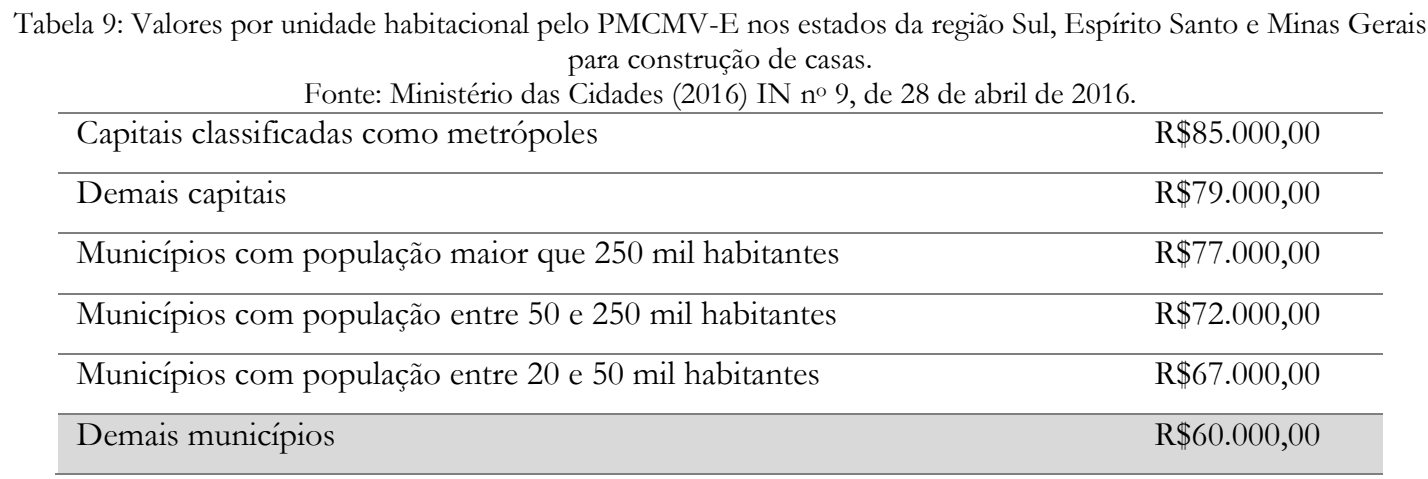

Assim, poderíamos simular que uma casa construída pelo programa MCMV-Entidades para um grupo de famílias com renda bruta familiar mensal até $\mathrm{R} \$ 1.800,00$ no perímetro urbano de Santa Terezinha, município da mesorregião Norte Catarinense - com 8.767 habitantes -, teria acesso a

\footnotetext{
${ }^{57}$ De acordo com a Pauta Unitária para Habitação Rural, publicada final do ano de 2013 e assinada por Contag, Movimento dos Pequenos Agricultores (MPA), MST, Movimento dos Atingidos por Barragens (MAB), Movimento Camponês Popular (MCP) e $\quad$ Fetraf-Brasil. $\quad$ Disponível em http://contrafbrasil.org.br/sistema/ck/files/Pauta $\% 20$ unitaria $\% 20$ HABITACAO $\% 20$ RURAL.pdf, $\quad$ acessado em 20/12/2016.
} 
$\mathrm{R} \$ 60.000,00$ por unidade habitacional. O mesmo grupo de famílias, se morasse na área rural do mesmo município e tivessem como ocupação a agricultura ${ }^{58}$ e renda familiar bruta anual até $\mathrm{R} \$ 17.000,00$, este grupo teria acesso a $\mathrm{R} \$ 34.200,00$ por unidade habitacional. Isso significa que as famílias de agricultores estariam recebendo o equivalente a $57 \%$ do recurso total do programa habitacional que receberiam as famílias que moram dentro do perímetro urbano. Esta proporção poderia ser ainda mais impactante se comparássemos a construção de uma casa dentro e fora do perímetro urbano de municípios catarinenses de maior porte, como Lages, por exemplo - com mais de 150 mil habitantes, podendo acessar até $\mathrm{R} \$ 72.000,00$ por unidade habitacional pelo MCMVEntidades -, ou Joinville - com quase 500 mil habitantes, acessando $\mathbf{R} \$ 77.000,00$ por unidade habitacional - ou mesmo Florianópolis, a capital do estado - acessando $\mathbf{R} \$ 79.000,00$ por unidade habitacional. O recurso do PNHR corresponderia, nesses casos, respectivamente a 47,5\%, 44\% e $43,2 \%$ do programa urbano correlato. No limite, poderíamos extrapolar ainda mais a simulação dessa diferença tendo como referência o valor mais alto que pode ser acessado pelo MCMV-Entidades atualmente, isto é, $\mathrm{R} \$ 93.000,00$ para os residentes dos perímetros urbanos das metrópoles dos estados de São Paulo, Rio de Janeiro e Distrito Federal: o recurso que os camponeses das áreas rurais destas metrópoles poderiam acessar para construir suas casas corresponderia a apenas 36\% do recurso de seus correlatos trabalhadores urbanos.

Este valor mais alto para o MCMV-Entidades poderia ser justificado, num primeiro momento, pelo investimento necessário para aquisição do terreno - lembrando que, no meio urbano, o recurso disponibilizado para a obra deve cobrir também este item, geralmente bastante caro. Pelas regras do programa, porém, este valor não pode ultrapassar 15\% do recurso total disponível para obra. Assim, para São Paulo subtrairíamos 15\% do valor total disponível para a produção da casa no perímetro urbano e teríamos disponível, exclusivamente para o processo construtivo da edificação, o valor de R \$79.050,00 - ou seja, a obra da casa na área rural pelo PNHR também no município de São Paulo receberia $43 \%$ do recurso que recebe a obra do MCMV-Entidades, ainda uma diferença muito significativa.

Se considerarmos que o projeto arquitetônico é geralmente muito similar ao dos programas habitacionais no meio urbano, tanto quanto à distribuição espacial, à área construída, aos materiais de acabamento e ao sistema construtivo, este rebaixamento do valor do PNHR não demonstra nem justifica fundamento em nenhuma outra regra do programa. Os materiais utilizados para as obras do PNHR devem ser, da mesma forma que no MCMV-Entidades, padronizados e de qualidade certificada - a não ser por poucas exceções verificadas em nosso trabalho de campo, como a permissão do uso de madeira extraída do lote, como veremos à frente. Além disso, os materiais de

\footnotetext{
${ }^{58} \mathrm{E}$ que se adequassem a todas as determinações da Lei 11.326/2006.
} 
construção são geralmente comprados na "cidade", ou seja, nas lojas dentro do perímetro urbano do município. Portanto, poderíamos, no limite, imaginar uma situação hipotética em Santa Terezinha, na qual os dois grupos - o que acessa o MCMV-Entidades e o que acessa o PNHR - visitariam ao mesmo tempo a mesma loja de materiais de construção e comprariam os mesmos materiais em quantidades similares. $\mathrm{O}$ valor final da compra seria praticamente o mesmo, exceto pelo fato de que o preço do frete seria mais alto para o grupo do PNHR, já que este é habitualmente maior para quem mora mais longe, na área rural. Além disso, é válido afirmarmos que o valor final da obra seria maior para o grupo do PNHR também devido aos custos que implica um canteiro de obras disperso, como é característico dos assentamentos rurais no Brasil: esta característica dificulta ganhos em escala na compra de materiais e na organização da mão-de-obra, implica gastos de tempo e de deslocamento no canteiro de obras para distribuição dos materiais, de ferramentas, fiscalização, etc.

Este rebaixamento do valor do programa, injustificável portanto do ponto de vista do processo produtivo da casa, não pode ser explicado senão pela aceitação geral e velada de que o campesinato não merece mais do que o direito a uma "cidadania de segunda ordem"; e que uma pretensa "cidadania de primeira linha" ficaria, tacitamente, exclusivamente concedida aos sujeitos essencialmente urbanos, habitantes das cidades. (LOPES; BORGES, 2013). Além disso, parece possível supor que os mecanismos de reprodução de valor que essas linhas de financiamento habitacional mobilizam, também diferem conforme os contextos territoriais em que são operados: talvez o custo da terra e os valores de localização no contexto urbano demandem maiores montantes de recursos para uma adequada transformação da mercadoria em valor. Como o valor da terra na zona rural é, via de regra, mais baixo que na cidade, o montante de recursos aplicado na produção do acessório - a casa - equivale, proporcionalmente, ao valor atribuído ao principal, isto é, a terra: terra mais cara, maior o montante de capital investido para reproduzir valor; terra mais barata, o inverso. Claro que essa equação importa exclusivamente ao capital - e não aos camponeses que precisam de moradia adequada às suas necessidades. Este é um aspecto que mereceria ser estudado juntamente ao problema do valor da terra no PNHR, indicado anteriormente.

Mas como os camponeses contornam este problema na prática? Como concretizam a construção das suas habitações hoje com menos recursos do que o necessário? No estudo de caso que investigamos, o principal artifício para que se atinja esta meta é o incentivo e preparo das famílias, por parte da Entidade Organizadora, para a organização da obra em regime de autoconstrução, internalizando assim os custos referentes à mão-de-obra, reduzindo o valor aplicado e viabilizando a sua realização com os recursos do programa. À frente estudaremos com mais detalhes uma experiência de produção habitacional com este perfil e, com base nela, teremos 
elementos para analisar o seu significado à luz das principais reflexões sobre a problemática da produção habitacional no país.

\subsubsection{Déficit habitacional rural versus produção do PNHR/MCMV}

Assim como para as modalidades urbanas do programa MCMV, também para o PNHR o argumento relacionado à redução do déficit habitacional é utilizado como forma de justificar a importância de sua execução. No caso do PNHR, inclusive, esta relação entre o programa e o déficit habitacional rural está explicitado na metodologia para distribuição de metas físicas, conforme consta na Portaria Interministerial n ${ }^{\circ} 326$, de 31 de agosto de 2009:

Art. $4^{\circ}$ Os recursos do PNHR encontram-se distribuídos entre as Unidades $\mathrm{da}$

Federação, na forma do Anexo III desta Portaria.

$\int 1^{\circ}$ A distribuição entre Unidades da Federação foi efetuada de acordo com a estimativa do déficit habitacional, para as áreas rurais, considerando os dados da Pesquisa Nacional por Amostra de Domicílios - PNAD, da Fundação Instituto Brasileiro de Geografia e Estatística - IBGE, referentes ao ano de 2007 e suas atualizações. (BRASIL, 2009, grifo nosso)

O déficit habitacional nas áreas rurais, classificado pela Fundação João Pinheiro, considera três componentes diferentes: habitações precárias, coabitação familiar e adensamento excessivo de domicílios alugados, conforme descrição abaixo.

O primeiro componente, habitações precárias, considera no seu cálculo dois subcomponentes: os domicílios rústicos e os domicílios improvisados. Os domićlíos rústicos são aqueles sem paredes de alvenaria ou madeira aparelhada. Em decorrência das suas condições de insalubridade, esse tipo de edificação proporciona desconforto e traz risco de contaminação por doenças. Já os domicílios improvisados englobam todos os locais e imóveis sem fins residenciais e lugares que servem como moradia alternativa (imóveis comerciais, embaixo de pontes e viadutos, carcaças de carros abandonados, barcos e cavernas, entre outros), o que indica claramente a carência de novas unidades domiciliares.

O segundo componente, coabitação familiar, também é composto por dois subcomponentes: os cômodos e as famílias conviventes secundárias que desejam constituir novo domicílio. Os cômodos foram incluídos no déficit habitacional porque esse tipo de moradia mascara a situação real de coabitação, uma vez que os domicílios são formalmente distintos. Segundo a definição do IBGE, os cômodos são domicílios particulares compostos por um ou mais aposentos localizados em casa de cômodo, cortiço, cabeça de porco e outros. O segundo subcomponente diz respeito às famílias secundárias que dividem a moradia com a família principal e desejam constituir novo domićlíio.

$[\ldots]$ 
O quarto e último componente é o adensamento excessivo em domicílios alugados que corresponde aos domicílios alugados com um número médio superior a três moradores por dormitório (FJP, 2013, p. 5) ${ }^{59}$.

Conforme a Fundação João Pinheiro, o país apresenta atualmente um déficit de 1.055.163 domicílios na área rural. Destes, 64,7\% estão enquadrados devido ao primeiro componente, habitações precárias, o que signfica que as paredes da casa são feitas de materiais que não alvenaria ou madeira aparelhada ou que são espaços que não configuram habitação. A maior parte deste componente do déficit está localizado na região Norte e Nordeste do país, onde é sabido que grande parte das casas no meio rural são construídas com técnicas de terra crua. Já em Santa Catarina, não é este o componente que mais se destaca, mas sim a coabitação familiar, motivo para $60,9 \%$ das habitações terem sido enquadradas como déficit habitacional - é muito comum no campesinato catarinense encontrar o filho morando com sua esposa na casa dos pais, por falta de disponibilidade de terras ou condições de adquiri-las.

Porém, é fato que, do ponto de vista do funcionamento efetivo do programa e das regras que temos conhecimento, não há qualquer relação direta entre as habitações que se enquadram no levantamento do déficit habitacional rural e os critérios para definição da demanda que será atendida pelo PNHR. A única relação é através da distribuição das metas físicas do programa, o que não significa muito uma vez que estas podem ser negociadas e alteradas - e geralmente o são, de acordo com a capacidade das entidades de cada estado em produzir as unidades habitacionais. Não há oficialmente, por exemplo, uma listagem de famílias que, por razões objetivas, constituam prioridade no atendimento habitacional, por município, como suporte na definição critérios de atendimento do PNHR. Os critérios para seleção das famílias que participam do programa, segundo as normativas, não se relacionam com a precariedade da habitação, com a coabitação familiar ou o adensamento excessivo - a não ser que a Entidade Organizadora assim o determine (como foi o caso de um dos municípios visitados).

Além disso, não são implementados mecanismos para aferir se as famílias moradoras das casas consideradas pelo levantamento do déficit habitacional são de fato público-alvo do programa, principalmente em função de apresentarem ou não a condição de proprietários do sítio que ocupam como já vimos, este é um dos critérios eliminatórios para acesso ao programa.

Portanto, a inexistência desta vinculação efetiva entre os critérios de atendimento do programa e o déficit habitacional rural torna falso o estabelecimento de relações entre os números da produção

${ }^{59}$ O terceiro componente, “ônus excessivo por aluguel urbano", não é considerado para o cálculo do déficit habitacional em áreas rurais, cujo enquadramento deve atender aos seguintes critérios simultaneamente: seja localizado na área urbana, a renda domiciliar dos moradores deve ser de até 3 salários mínimos, seja alugado e apresente a razão entre valor do aluguel e rendimento domiciliar seja superior a 0,3 (30\%) (FJP, 2013, p.19). 
habitacional do PNHR e os dados do déficit, sendo assim equivocado supor que, automaticamente, este estaria sendo reduzido por aquele.

Além disso, compreendemos que nem todos os componentes do déficit são plenamente resolvidos apenas pela construção de novas casas. Se, por um lado, o primeiro componente do déficit, habitações precárias, indica a existência de fatores relacionados à não disponibilidade de materiais de construção e mão-de-obra (como pouca disponibilidade de materiais construtivos no local, baixo poder aquisitivo para adquiri-los ou mesmo inexistência do conhecimento construtivo entre os integrantes da família ou da vizinhança), o segundo componente, coabitação familiar, poderia ser interpretado menos como um indicador de uma necessidade material-construtiva e mais como indicador de um problema de ordem fundiária ou de demanda por reforma agrária. Assim, em Santa Catarina, por exemplo, seria inócuo buscar a redução do déficit habitacional rural apenas construindo mais casas sem colocar em prática ações mais profundas relacionadas a estrutura fundiária do estado como um todo.

\subsubsection{A inadequação do regime de construção sob o PNHR ao modo de vida camponês}

A autoconstrução da moradia no meio rural nada tem a ver com a autoconstrução na periferia das metrópoles brasileiras. Como veremos a frente, a prática da autoconstrução da habitação é muito comum no campesinato e parece ser de fato o regime de construção mais adequado ao modo de vida camponês. Porém, quando vinculada à rotina de liberação dos recursos do programa habitacional, o fluxo operacional apresenta sérios entraves para sua realização, principalmente por este não se adequar aos tempos da família camponesa: o cronograma da construção civil invariavelmente não coaduna com o cronograma do plantio, do manejo e da colheita. No $3^{\circ}$ capítulo vamos tratar deste tema de um ponto de vista teórico. Para o momento, gostaríamos de pontuar de maneira mais geral a inadequação a que nos referimos.

A dinâmica do trabalho camponês possui condicionantes diferentes daquelas que submetem o trabalho no meio urbano. O trabalho no campo não se organiza por semanas e finais de semana - o tempo livre tem outras particularidades e se estabelece em função de outros parâmetros. Os horários de dedicação à produção de alimentos para comercialização, que envolvem a ida e a volta da roça diariamente, os trabalhos relacionados à produção do autoconsumo, a divisão das tarefas entre os integrantes da família, são dinâmicas que variam de acordo com a época do ano, o tipo de cultivo, o número e idade dos integrantes da família, e diversos outros fatores. Como veremos no $3^{\circ}$ capítulo, à exceção de alguns casos, o trabalho diário da família camponesa não se organiza a partir de leis externas, mas a partir das condicionantes dadas em grande parte pela própria organização interna da família. 
Um requisito relevante na dinâmica do trabalho camponês é a atenção ao calendário agrícola de cada tipo de cultivo. Na região Sul do país, por exemplo, são comuns algumas culturas muito distintas como o fumo, o feijão, a aveia e o trigo. Cada uma destas culturas possui épocas de plantio e de colheita diferentes: o fumo deve ser plantado de agosto a dezembro e a colheita deve acontecer de dezembro a fevereiro; já a aveia deve ser plantada de abril a junho, e a colheita deve ser feita de outubro a dezembro. Nas épocas de plantio e colheita, o tempo da família camponesa é inteiramente dedicado à estas atividades, do nascer ao pôr do sol. Porém, após a colheita e antes do próximo plantio, existe o período chamado de entressafra, que é o período em que a família se dedica à organização dos outros aspectos de suas vidas que não exclusivamente a produção do alimento para comercialização. É neste período, por exemplo, que alguns integrantes da família vão trabalhar fora de sua propriedade para complementar a renda familiar - o chamado trabalho acessório -, seja ajudando na colheita dos vizinhos, seja atuando na construção civil na cidade, por exemplo. É também neste período que a família pode se dedicar a atividades referentes ao seu autoconsumo, como a construção ou reforma da própria casa.

Já em outros tipos de atividade agropecuárias também comuns no campesinato catarinense como avicultura, suinocultura ou produção de laticínios - o tempo da família não é organizado pelos momentos de safra e entressafra, mas sim pela distribuição das tarefas ao longo do dia, diariamente. No caso da produção de laticínios, por exemplo, o formato mais comum de organização do trabalho entre as famílias camponesas catarinenses que trabalham com gado leiteiro é configurado pela comercialização do leite para uma grande empresa; neste caso, a tarefa cotidiana da família consiste na ordenha e no armazenamento do leite em equipamento adequado (geralmente especificado e exigido pela empresa), na alimentação das vacas, manutenção do equipamento e do espaço etc. São tarefas que tomam parte do dia, geralmente desde antes do nascer do sol até a metade da manhã e, depois, novamente no final da tarde. O camponês tem livre, portanto, não um período de meses - como na entressafra -, mas sim períodos diários, momentos em que pode realizar outras tarefas como, por exemplo, dedicar-se à construção da sua casa (ou mesmo a de vizinhos).

Entrar nesses detalhes do mundo do trabalho camponês é essencial para verificarmos a inadequação das regras referentes ao regime de construção do PNHR ao modo de vida de seu públicoalvo. Conforme veremos mais detalhadamente, o recurso disponível para a construção da casa pelo programa é insuficiente e invariavelmente conta com o trabalho da família na obra, em regime de autoconstrução, para que seja possível "fechar a conta". Porém, haja vista que este modelo de provisão pública de habitação acaba se assemelhando mais a um "prêmio" do que à garantia de um direito, a família não tem o mínimo controle sobre quando e se será selecionada para o benefício a partir do momento em que se inscreve no programa. Não pode assim se organizar para o processo de 
obra de forma compatível com sua dinâmica produtiva. Se ela lograr ser selecionada para o programa, precisará esperar até que o contrato seja assinado, para que a primeira parcela de $15 \%$ do recurso seja liberada para fazer a compra dos materiais e dar início à obra; e torcer para não ocorrerem atrasos nas liberações seguintes do recurso, para ter sua casa finalizada. Ou seja, o PNHR insere a família em uma série de procedimentos que não proporcionam segurança alguma em relação a prazos ou mesmo à própria finalização da obra. A família não consegue, assim, minimamente planejar-se para construir a própria casa.

Para resolver estes problemas - por exemplo, quando a contratação do grupo no PNHR e, consequentemente, o início das obras, acontece justamente na época da safra - muitas famílias acabam tendo que complementar a verba do programa com recursos próprios, na contratação da mão-de-obra de algum conhecido ou parente - ou outra pessoa que aceite receber o pagamento pelo serviço apenas dali uns meses, depois da safra.

Ao que tudo indica, essas limitações do PNHR/MCMV não coibiram ou impediram o surgimento de arranjos operacionais alternativos que, em se valendo das dificuldades de acesso ao programa, de operação dos recursos de financiamento e de administração de projetos e obras, engendraram mecanismos de empresariamento especializados justamente na superação de tais limitações. É este o caso da Cooperativa Habitacional dos Agricultores Familiares, a Cooperhaf que, a seguir, nos servirá como estudo de caso para aprofundarmos nossa compreensão de como a produção habitacional camponesa, promovida a partir de um programa como o PNHR/MCMV, pode revestir-se de conteúdos que não só não enfrentam questões como a da propriedade da terra ou das especificidades do modo de vida camponês, como também acabam não afrontando os processos que mantêm e reproduzem as precárias condições de vida nos campos, nas águas, nas florestas ou em todo território não urbano do país.

\subsection{O “arranjo Cooperhaf/Sintraf” na produção habitacional camponesa}

Fundada em outubro de 2001 no município de Sarandi, a Cooperhaf atuou inicialmente apenas no Rio Grande do Sul, como representante da Fetraf-Sul num formato experimental de produção de habitação rural do governo Olívio Dutra. A partir de 2004 a cooperativa passou a atuar nos demais estados da região Sul e, a partir de 2006, também em outros estados do país: Pará, Maranhão, Pernambuco, Rio Grande do Norte, Bahia, Ceará, Minas Gerais, São Paulo, Mato Grosso do Sul e Piauí. Esta expansão das atividades para outros estados acompanhou a expansão dos próprios sindicatos ligados à recém-criada Fetraf-Sul - como vimos no $1^{\circ}$ capítulo, a federação de sindicatos 
que surgiu por dissidência ao sindicalismo da Contag dentro da CUT. Hoje a Cooperhaf voltou a restringir sua atuação apenas para a região Sul, e mantém sua presença em outros estados através de parcerias com as cooperativas habitacionais ligadas aos Sintrafs locais como Bahia, São Paulo e Mato Grosso do Sul. O fato de vir atuando desde as primeiras experiências de produção de habitação rural no país (já que sempre trabalharam com os programas habitacionais disponíveis, desde o PSH-Rural e CCFGTS) concede à Cooperhaf certo "lugar privilegiado" para observar aspectos e dinâmicas que envolvem essa temática - o que a torna, diga-se de passagem, um interessante objeto para uma pesquisa como a que aqui se propõe.

Sua organização física é composta por sua matriz - que hoje é localizada no município de Chapecó/SC -, e pelas três filiais - localizadas no Paraná (município de Francisco Beltrão), em Santa Catarina (município de Chapecó) e no Rio Grande do Sul (município de Sarandi). A organização interna da matriz é estruturada pelas funções de presidente, secretário geral, tesoureiro, secretaria, tecnologia social, gestão administrativa, engenharia/arquitetura, contabilidade, financeiro e tecnologia da informação. As três filiais estruturam-se em torno das funções: secretaria, analista documental, pagamentos, engenharia/arquitetura, social, coordenação técnica e coordenação geral. Desde 2006 todos os funcionários possuem carteira assinada via CLT, exceto a advogada, que presta serviços. Em 2015 a Cooperhaf possuía cerca de 50 funcionários, considerando a matriz e as três filiais.

Figura 4: Matriz da Cooperhaf no município de Chapecó em dezembro de 2014

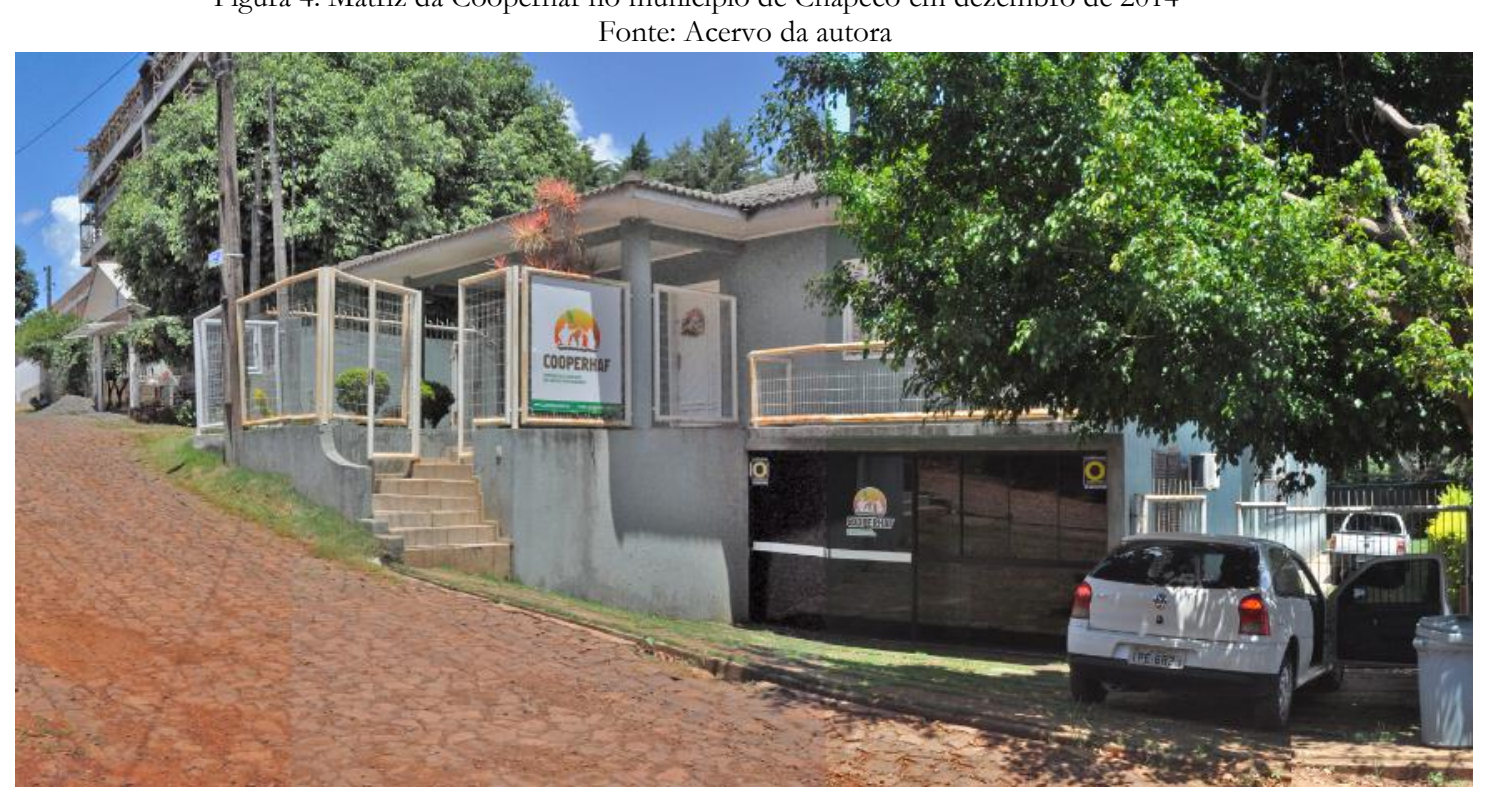

O trabalho da Cooperhaf é realizado em parceria com os sindicatos locais ligados à Fetraf, chamados Sintraf. Nesta parceria a Cooperhaf assume as responsabilidades da EO perante a CEF, e os sindicatos dão o suporte direto nos canteiros de obras. 
A Cooperhaf teve seu primeiro contrato no âmbito do PNHR/MCMV assinado em 28 de maio de 2010, para a construção de 12 unidades no município de Tiradentes do Sul, no Rio Grande do Sul, e três dias depois, em 31 de maio de 2010, a Cooperhaf assinou uma sequência de dez contratos na mesorregião do Oeste Catarinense, todos para a construção de casas, totalizando 82 unidades.

A sua atuação na região Sul do Brasil é bastante relevante: até dezembro de 2016, a cooperativa foi responsável por $14,5 \%$ dos contratos de reforma e construção pelo programa. Sua presença é ainda mais marcante em Santa Catarina, onde foi responsável por 24,62\% do total de contratos, e no Paraná, onde foi responsável por 25,45\%. Sua atuação no Rio Grande do Sul é numérica e proporcionalmente menor, chegando a apenas 2,91\% do total das unidades contratadas.

No estado de Santa Catarina, a Federação dos Trabalhadores Rurais Agricultores e Agricultoras Familiares do Estado de Santa Catarina (FETAESC) é a entidade organizadora responsável pela maior quantidade de contratos desde 2009, um total de 5.506 unidades, o que corresponde a 36,94\% do total no estado. A Cooperhaf aparece em segundo lugar com 3.670 unidades $(24,62 \%$ dos contratos), e em terceiro lugar aparecem as prefeituras municipais, responsáveis por $11,42 \%$ do total. $\mathrm{Na}$ Tabela 10 estão elencadas as sete entidades organizadoras que juntas assumiram 87,25\% dos contratos do estado de 2009 a dezembro de 2016.

Tabela 10: Entidades Organizadoras atuantes em Santa Catarina, por ordem de número de contratos, entre 2009 e dezembro de 2016.

Fonte: Elaboração própria a partir de CEF, 2016.

\begin{tabular}{|c|c|c|}
\hline Entidade Organizadora & un. contratadas & $\%$ total em SC \\
\hline $\begin{array}{l}\text { FETAESC } \\
\text { Federação dos Trabalhadores na Agricultura do Estado de } \\
\text { Santa Catarina }\end{array}$ & 5.506 & $36,94 \%$ \\
\hline $\begin{array}{l}\text { COOPERHAF } \\
\text { Cooperativa de Habitação dos Agricultores Familiares }\end{array}$ & 3.670 & $24,62 \%$ \\
\hline PREFEITURAS MUNICIPAIS & 1.703 & $11,42 \%$ \\
\hline $\begin{array}{l}\text { PRÓ MOVER } \\
\text { Associação Para o Desenvolvimento Social e } \\
\text { Aperfeiçoamento do Cidadão }\end{array}$ & 1.173 & $7,87 \%$ \\
\hline $\begin{array}{l}\text { CRESOL } \\
\text { Cooperativas de Crédito Rural com Interação Solidária }\end{array}$ & 384 & $2,58 \%$ \\
\hline $\begin{array}{l}\text { AEPAC } \\
\text { Associação Estadual de Pequenos Agricultores Catarinenses }\end{array}$ & 363 & $2,44 \%$ \\
\hline $\begin{array}{l}\text { CREHNOR } \\
\text { Cooperativa de Crédito Rural Horizontes Novos de Novo } \\
\text { Sarandi Ltda. }\end{array}$ & 207 & $1,39 \%$ \\
\hline
\end{tabular}

A Cooperhaf também atua desde 2009 em projetos de loteamentos urbanos. Com empréstimos da CRESOL compram a gleba e promovem a legalização e regularização do loteamento, contratam uma empresa para construir as casas pelo programa MCMV e realizam o Trabalho Social (TS) com as famílias - uma exigência do PNHR/MCMV, tal como na modalidade Entidades. O fato desta atividade ser executada pela cooperativa e ao mesmo tempo não estabelecer relação alguma com as 
formas de trabalho e o modo de vida dos camponeses associados é um importante dado de pesquisa, que merece ser estudado em outra oportunidade.

\subsubsection{Metodologia do trabalho de campo}

A pesquisa de campo foi dividida em duas etapas, procurando cobrir da melhor maneira possível as diferentes etapas do processo produtivo das casas promovido pela Cooperhaf. As táticas utilizadas em ambas as etapas foram entrevistas semiestruturadas, observação não participante e anotações de campo.

A primeira etapa foi realizada em dezembro de 2014 e consistiu na visita à sede da cooperativa, localizada no município de Chapecó, extremo-oeste do estado. Foram realizadas entrevistas semiestruturadas com funcionárias da matriz e da filial Santa Catarina ao longo de três dias, observação não participante do cotidiano e das instalações da matriz e anotações contínuas no caderno de campo.

A segunda etapa do trabalho de campo foi realizada em setembro de 2015 e consistiu na visita a diversos canteiros de obras de empreendimentos sob responsabilidade da Cooperhaf. O objetivo era compreender em nível estadual a etapa da construção das casas na interface entre os sindicatos municipais, a mão-de-obra e as famílias. Em cada um dos municípios visitados foram realizadas entrevistas semiestruturadas com o coordenador municipal de habitação do Sintraf local, com o responsável pela mão-de-obra no canteiro, com a família de agricultores beneficiados e com o proprietário de uma das lojas de materiais de construção de cada cidade que participa no fornecimento dos materiais. Foi realizada a observação não participante no canteiro de obras e nas instalações do sindicato seguidas de anotações no caderno de campo.

Figura 5: Canteiro de obras sob supervisão do Sintraf de Anita Garibaldi, em setembro de 2015

Fonte: Acervo da autora
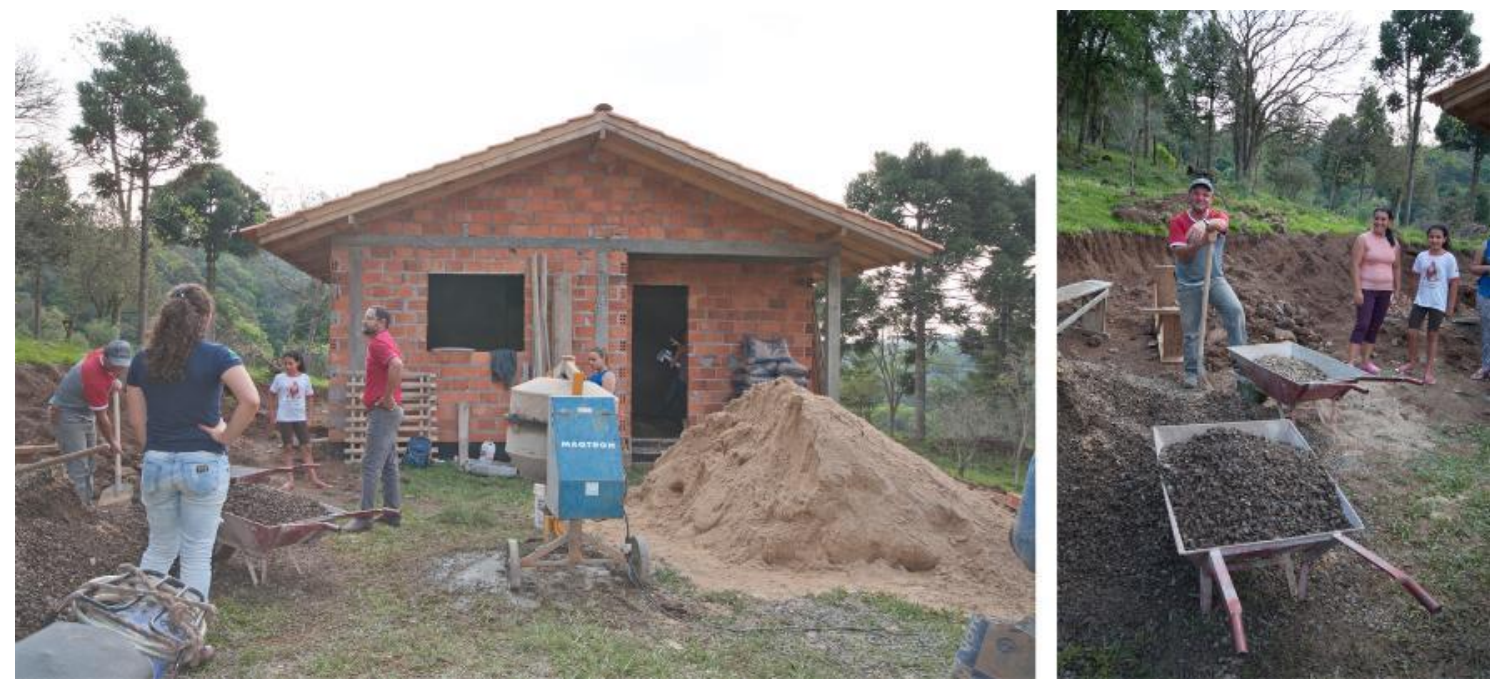
Foram visitados cinco municípios do estado de Santa Catarina, cada um deles localizado em uma mesorregião diferente: Alfredo Wagner, localizado na Grande Florianópolis; Anita Garibaldi, localizado na mesorregião Serrana; Irani, localizado no Oeste Catarinense; Ituporanga, localizado no Vale do Itajaí, e Santa Terezinha, localizado no Norte Catarinense (indicados no mapa da

Figura 6, na página 73). Os critérios para escolha dos municípios que seriam incluídos na segunda etapa do trabalho de campo foram: a) a existência de obras em andamento promovidas através da parceira Cooperhaf/Sintraf; b) o andamento da obra - que deveria encontrar-se entre as etapas inicial e intermediária; c) a representatividade dos municípios frente à mesorregião quanto a características gerais da população; d) as informações obtidas com a Cooperhaf a respeito da estrutura interna de cada sindicato municipal. Cabe ainda ressaltar que, para assegurar a viabilidade dos trabalhos de pesquisa, consideramos também as condições de acesso da pesquisadora aos municípios em relação aos recursos humanos e financeiros disponíveis.

Levando em consideração que o objetivo desta pesquisa é analisar a produção habitacional camponesa, consideramos como critério principal para a escolha dos municípios que seriam visitados aqueles que possuíssem, à época, obras do PNHR em andamento sob responsabilidade da Cooperhaf. Esse recorte limitou nosso universo em 29 municípios nos quais se encontravam em andamento obras dos contratos de construção e 12 municípios onde se realizavam obras dos contratos de reforma. A Tabela 11 abaixo resume as informações por mesorregião.

Tabela 11: Municípios com obras em andamento pela Cooperhaf em setembro de 2015

\begin{tabular}{|c|c|c|c|c|c|c|}
\hline \multirow{3}{*}{ mesorregião } & \multirow{3}{*}{$\begin{array}{c}\text { municípios } \\
\text { total }\end{array}$} & \multirow{3}{*}{$\begin{array}{l}\text { municípios } \\
\text { com PNHR }\end{array}$} & \multicolumn{4}{|c|}{ municípios com obras em andamento pela Cooperhaf } \\
\hline & & & \multicolumn{2}{|c|}{ CONSTRUÇÃO } & \multicolumn{2}{|c|}{ REFORMA } \\
\hline & & & n. municípios & n. unidades & n. municípios & n. unidades \\
\hline Santa Catarina & 295 & 199 & 29 & 522 & 12 & 162 \\
\hline Grande Florianópolis & 21 & 14 & 1 & 53 & 1 & 12 \\
\hline Norte Catarinense & 26 & 13 & 3 & 32 & 0 & 0 \\
\hline Oeste Catarinense & 118 & 100 & 17 & 315 & 9 & 114 \\
\hline Serrana & 30 & 23 & 6 & 72 & 1 & 16 \\
\hline Sul Catarinense & 46 & 21 & 1 & 11 & 1 & 20 \\
\hline Vale do Itajaí & 54 & 28 & 1 & 39 & 0 & 0 \\
\hline
\end{tabular}

Para otimizar a operacionalização da pesquisa, optamos pelas cidades onde estavam sendo promovidas construções e reformas ao mesmo tempo - o que, por conseguinte, favoreceu a verificação dos padrões adotados para gestão das obras.

As obras em andamento na mesorregião Sul Catarinense estavam praticamente finalizadas e, portanto, não atendiam ao critério principal de seleção dos municípios. Por este motivo esta mesorregião não foi visitada. 
Foram analisadas também informações gerais de cada município: número de habitantes, porcentagem da população em áreas rurais ${ }^{60}$, IDHM - Índice de Desenvolvimento Humano Municipal e rendimento nominal dos domićlios na área urbana e área rural. Apesar de não serem variáveis determinantes na escolha dos municípios, sua utilização deu suporte para que o município escolhido tivesse características semelhantes à média da mesorregião, buscando assim certa representatividade.

Em conjunto com os outros critérios, também foram analisadas as condições de acesso ao município. Observamos a localização de cada município em relação às principais estradas do estado e a localização relativa entre os demais municípios que seriam visitados. O objetivo desse critério foi estabelecer um cronograma racional e exequível dentro do tempo e do recurso disponível - levando em consideração a inexistência de apoio financeiro institucional para a realização do trabalho de campo.

Figura 6: Localização dos municípios visitados no trabalho de campo. Fonte: elaboração própria a partir de base do IBGE

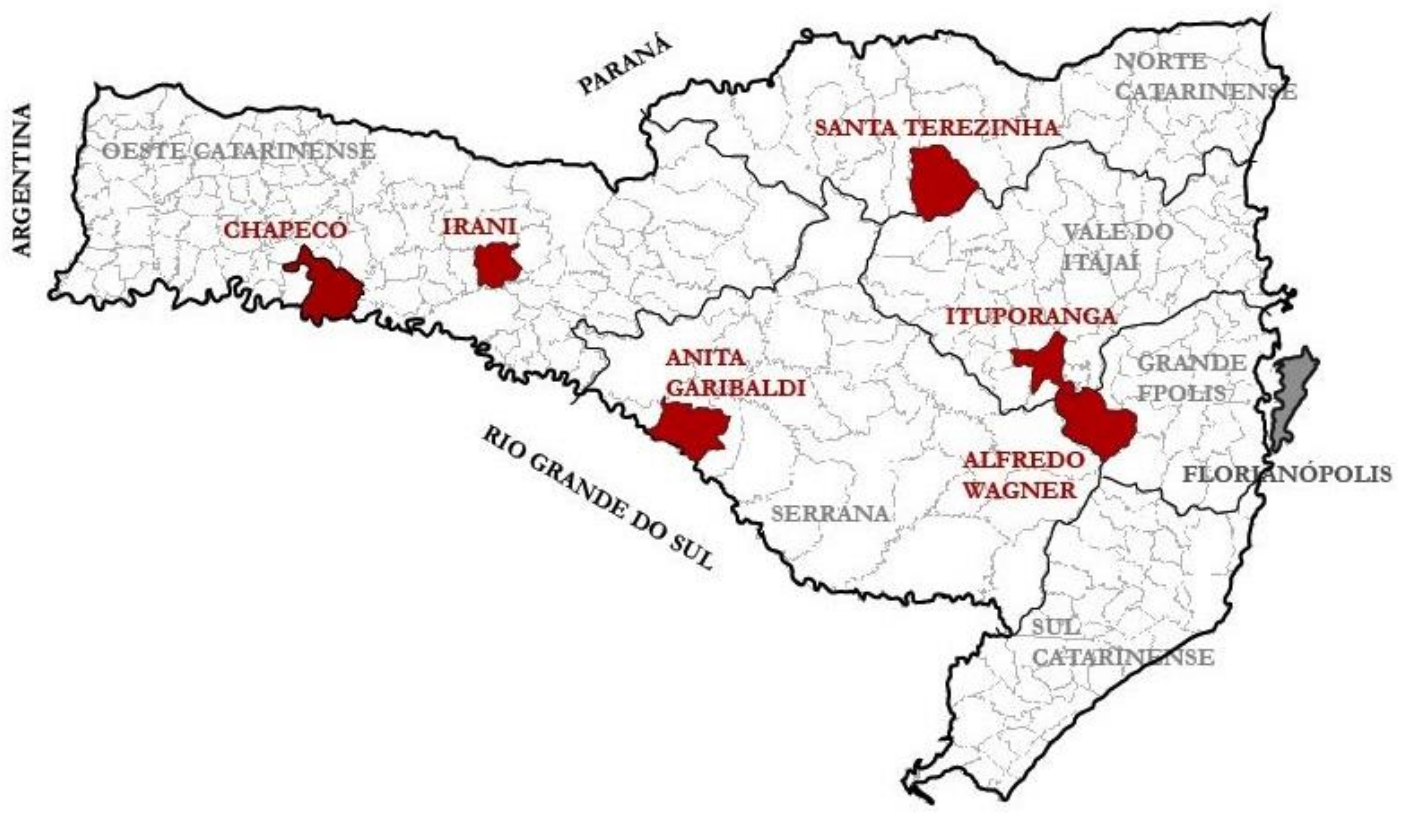

A Tabela 12 apresenta informações gerais sobre os municípios escolhidos para o trabalho de campo, e a

Figura 6 apresenta a localização de cada um deles no mapa do estado. Também está indicada no mapa a localização no município de Chapecó, onde fica a sede da matriz da Cooperhaf e a filial Santa Catarina, visitadas na primeira etapa do trabalho de campo.

Tabela 12: Resumo dos municípios visitados no trabalho de campo

\footnotetext{
${ }^{60}$ Quando definimos esses critérios ainda não dispúnhamos das informações do Censo Agropecuário, por essa razão aqui ainda utilizamos como critério a contagem da população rural.
} 
Fontes: (1) IBGE, 2010; (2) FJP, 2010; (3) CEF, 2015; (4) IBGE, 2006;

(5) a partir dos relatos e observações no trabalho de campo.

\begin{tabular}{|c|c|c|c|c|c|c|}
\hline & & $\begin{array}{c}\text { SANTA } \\
\text { TEREZINHA }\end{array}$ & IRANI & $\begin{array}{c}\text { ANITA } \\
\text { GARIBALDI }\end{array}$ & $\begin{array}{l}\text { ALFREDO } \\
\text { WAGNER }\end{array}$ & ITUPORANGA \\
\hline \multicolumn{2}{|c|}{ população (hab.) ${ }^{(1)}$} & 8.767 & 9.531 & 8.623 & 9.410 & 22.250 \\
\hline \multicolumn{2}{|c|}{ área total $\left(\mathrm{km}^{2}\right)^{(1)}$} & 715 & 325 & 587 & 732 & 336 \\
\hline \multicolumn{2}{|c|}{ dens. pop $\left(\mathrm{hab} / \mathrm{km}^{2}\right)^{(1)}$} & 13 & 29 & 14 & 13 & 70 \\
\hline \multicolumn{2}{|c|}{ domicílios totais $(1)$} & 2.497 & 2.886 & 2.709 & 2.959 & 6.839 \\
\hline \multicolumn{2}{|c|}{ domicílios rurais e \% (1) } & $2.042(82 \%)$ & $902(31 \%)$ & $1.244(46 \%)$ & $2.001(67 \%)$ & $2.191(32 \%)$ \\
\hline \multirow{2}{*}{$\begin{array}{l}\text { déficit } \\
\text { hab. rural } \\
\text { (2) }\end{array}$} & total & 89 & 81 & 60 & 98 & 55 \\
\hline & $\begin{array}{l}\text { por componente } \\
\text { (precário/coabit.) }\end{array}$ & $40 / 48$ & $43 / 37$ & $37 / 22$ & $34 / 64$ & $36 / 19$ \\
\hline \multicolumn{2}{|c|}{$\begin{array}{c}\text { número de estabelec. da } \\
\text { A.F. }\end{array}$} & $1.847(74 \%)$ & $578(20 \%)$ & $1.176(44 \%)$ & $1.763(60 \%)$ & $1.437(21 \%)$ \\
\hline \multicolumn{2}{|c|}{$\begin{array}{l}\text { atividade agropecuária } \\
\text { predominante }\end{array}$} & fumo & suínos & laticínio & cebola & cebola \\
\hline \multirow{2}{*}{$\begin{array}{l}\text { produção } \\
\text { PNHR (3) }\end{array}$} & construção & $\begin{array}{l}\mathrm{G} 1=57 \\
\mathrm{G} 2=-\end{array}$ & $\begin{array}{l}\mathrm{G} 1=31 \\
\mathrm{G} 2=12\end{array}$ & $\begin{array}{l}\mathrm{G} 1=51 \\
\mathrm{G} 2=-\end{array}$ & $\begin{array}{c}\mathrm{G} 1=79 \\
\mathrm{G} 2=4\end{array}$ & $\begin{array}{l}\mathrm{G} 1=509 \\
\mathrm{G} 2=\end{array}$ \\
\hline & reforma & $\begin{array}{c}\text { G1 }=- \\
\text { G2 }=33\end{array}$ & $\begin{array}{l}\mathrm{G} 1=- \\
\mathrm{G} 2=7\end{array}$ & $\begin{array}{l}\mathrm{G} 1=- \\
\mathrm{G} 2=-\end{array}$ & $\begin{array}{l}\mathrm{G} 1=- \\
\mathrm{G} 2=5\end{array}$ & $\begin{array}{l}\mathrm{G} 1=11 \\
\mathrm{G} 2=4\end{array}$ \\
\hline
\end{tabular}

Todas as entrevistas cedidas durante a segunda etapa do trabalho de campo obtiveram consentimento, por parte dos entrevistados, para utilização de seu conteúdo na presente pesquisa. O modelo do "Termo de Consentimento Livre e Esclarecido" utilizado encontra-se nos Anexos.

\subsubsection{Como funciona o acesso ao recurso}

É através do sindicato que os agricultores tomam conhecimento da oportunidade de acessar o recurso para construir ou reformar a sua casa. A divulgação é feita na sede do sindicato (vide Figura 7), que mostra o mural de um dos sindicatos visitados, com cartazes e panfletos alusivos às alternativas de financiamentos, mas também referentes à ofertas de empregos e classificados), nas reuniões anuais realizadas nas comunidades e, em alguns municípios, através da rádio local. Mas o que parece funcionar melhor são as informações transmitidas "boca a boca", circuladas pelas conversas e nos nos comentários entre vizinhos, parentes e conhecidos. Em alguns municípios a maioria dos agricultores já era sindicalizada e acessava outros serviços através do sindicato. Outra parte dos agricultores, porém, sindicalizaram-se exclusivamente para obter os benefícios do PNHR concretamente, para acessar o PNHR através do arranjo Sintraf/Cooperhaf, é obrigatório que o agricultor esteja associado a este sindicato.

$\mathrm{Na}$ medida em que os agricultores manifestam seu interesse em acessar o programa, o sindicato faz uma lista e, aos poucos, vai montando os grupos de famílias, que são divididos entre os que pretendem construir e os que pretendem reformar. Os critérios para determinação da prioridade das famílias que serão beneficiadas variam entre os sindicatos: alguns estabelecem a ordem de inscrição como critério, outros, a necessidade da família (avaliada por uma comissão formada pela diretoria do 
sindicato), e outros ainda, seguem as recomendações do Centro de Referência em Assistência Social (CRAS) do município.

No trabalho de campo, verificamos que as dificuldades no acesso ao PNHR eram similares na maioria dos municípios pesquisados. Dentre essas dificuldades, podemos detacar a renda limite muito baixa (haja vista o que discutimos a partir da página 59); a irregularidade na documentação da propriedade da terra; o fato do camponês ter o nome registrado no Cadastro Informativo de Créditos não Quitados do Setor Público Federal (CADIN) ou no Serviço de Proteção ao Crédito (SPC), ou pelo fato de já ter acessado recursos para fins habitacionais do governo e, por isso, constarem no Cadastro Nacional de Mutuários (CadMut).

Figura 7: Interior do Sintraf de Santa Terezinha em setembro de 2015
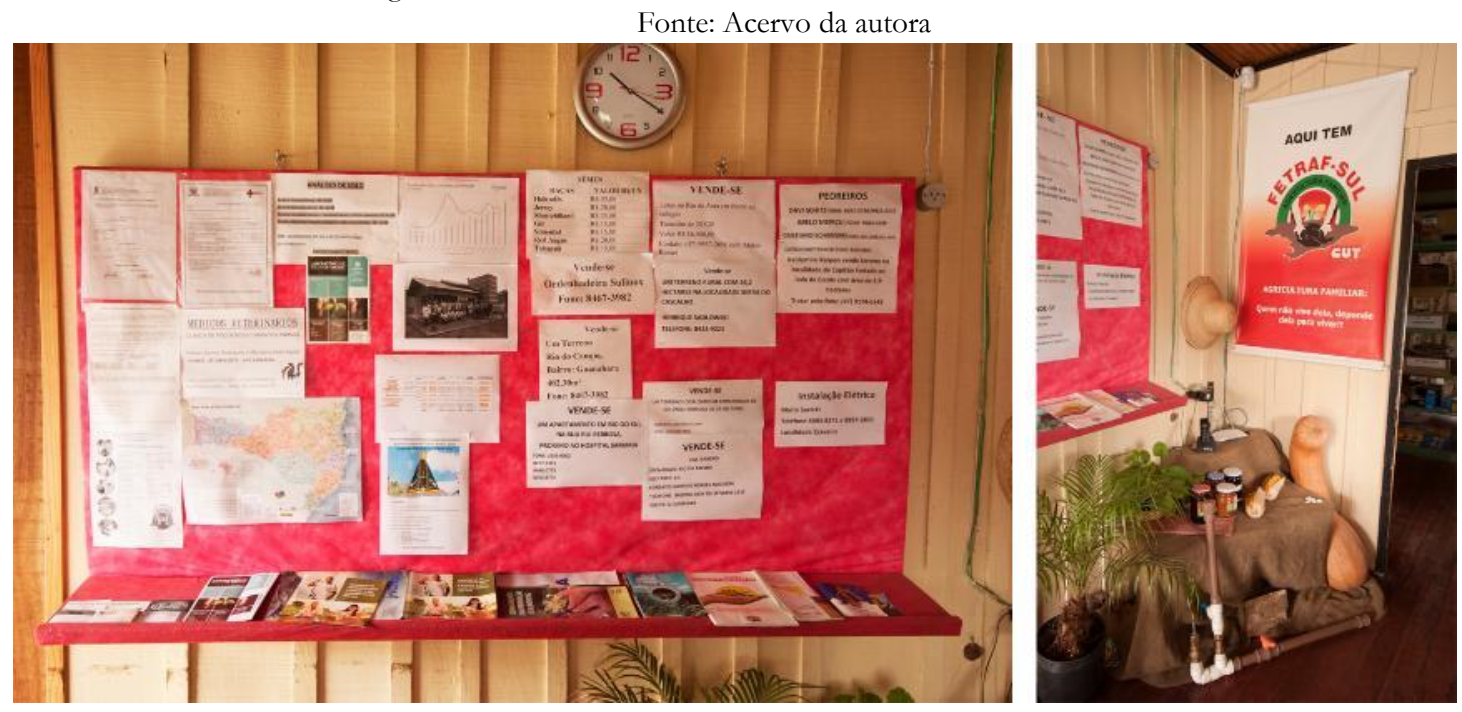

Os agricultores que são aprovados em todos os critérios de seleção passam a formar um grupo para acessar o programa. Os grupos são de, no mínimo, quatro e, no máximo, cinquenta famílias. Os grupos da modalidade "construção" devem escolher entre os oito modelos de casas disponibilizados pela cooperativa, que variam em tamanho, distribuição interna, materiais e valores, conforme a Tabela 13. As plantas dos oito modelos, assim como o projeto arquitetônico completo submetido à aprovação na CEF, podem ser encontradas nos Anexos a partir da página 113.

A escolha do modelo por cada família é regida, basicamente, pela sua capacidade de contrapartida. O modelo 1, que implica a menor contrapartida, é muitas vezes escolhido por esse motivo. A forma de pagamento da contrapartida é negociada com a loja e com o pedreiro e, muitas vezes, os agricultores conseguem boas condições, como prazos vinculados à remuneração pela safra e parcelamentos sem juros, para quitação da dívida. 
Tabela 13: Comparação entre as tipologias arquitetônicas pré-aprovadas, de autoria da Cooperhaf para o PNHR

Fonte: Elaborado a partir dos materiais enviados pela Cooperhaf

\begin{tabular}{|c|c|c|c|c|c|c|c|c|}
\hline & $\begin{array}{c}\text { Modelo } \\
01\end{array}$ & $\begin{array}{c}\text { Modelo } \\
02\end{array}$ & $\begin{array}{l}\text { Modelo } \\
03\end{array}$ & $\begin{array}{c}\text { Modelo } \\
04\end{array}$ & $\begin{array}{c}\text { Modelo } \\
05\end{array}$ & $\begin{array}{c}\text { Modelo } \\
06\end{array}$ & $\begin{array}{c}\text { Modelo } \\
07\end{array}$ & $\begin{array}{l}\text { Modelo } \\
\text { 09 PNE }\end{array}$ \\
\hline área & $50 \mathrm{~m}^{2}$ & $60 \mathrm{~m}^{2}$ & $60 \mathrm{~m}^{2}$ & $70 \mathrm{~m}^{2}$ & $70 \mathrm{~m}^{2}$ & $70 \mathrm{~m}^{2}$ & $70 \mathrm{~m}^{2}$ & $55,65 \mathrm{~m}^{2}$ \\
\hline n. de quartos & 2 & 2 & 3 & 2 & 3 & 3 & 2 & 2 \\
\hline cozinha e sala & separados & integrados & separados & integrados & integrados & integrados & integrados & separados \\
\hline lavanderia & externa & externa & interna & interna & externa & interna & interna & externa \\
\hline varanda & $\operatorname{sim}$ & $\operatorname{sim}$ & não & $\operatorname{sim}$ & $\operatorname{sim}$ & $\operatorname{sim}$ & $\operatorname{sim}$ & $\operatorname{sim}$ \\
\hline $\begin{array}{c}\text { divisória em } \\
\text { madeira }\end{array}$ & $\operatorname{sim}$ & $\operatorname{sim}$ & $\operatorname{sim}$ & não & não & não & não & $\operatorname{sim}$ \\
\hline $\begin{array}{c}\text { valor } \\
\text { materiais }\end{array}$ & $19.934,39$ & $21.112,15$ & $24.056,83$ & $25.158,38$ & $24.593,59$ & $27.473,57$ & $27.430,33$ & $21.684,86$ \\
\hline $\begin{array}{c}\text { valor } \\
\text { mão-de-obra }\end{array}$ & $8.585,61$ & $9.272,85$ & $10.073,17$ & $11.141,62$ & $11.046,41$ & $12.521,43$ & $11.964,67$ & $9.225,14$ \\
\hline $\begin{array}{c}\text { valor } \\
\text { total da } \\
\text { unidade }^{61}\end{array}$ & $28.520,00$ & $30.385,00$ & $34.130,00$ & $36.300,00$ & $35.640,00$ & $39.995,00$ & $39.395,00$ & $30.910,00$ \\
\hline $\begin{array}{c}\text { contrapartida } \\
\text { do agricultor } \\
\text { (acesso pelo } \\
\text { G1) }\end{array}$ & 20,00 & $1.885,00$ & $5.630,00$ & $7.800,00$ & $7.140,00$ & $11.495,00$ & $10.895,00$ & $2.410,00$ \\
\hline
\end{tabular}

Os grupos da modalidade "reforma" recebem o coordenador de habitação do sindicato em casa, e ele verifica inicialmente os indícios da estabilidade da edificação. Caso considere que a estrutura possa estar comprometida e que será arriscado realizar uma reforma, ele orienta a família a participar dos grupos de "construção". Em um dos municípios visitados no trabalho de campo, o coordenador de habitação comentou que, certa vez, permitiram uma reforma em uma casa que aparentava relativa estabilidade. No entanto, ao substituir as telhas - que eram de fibrocimento e passaram a ser de cerâmica -, o peso da cobertura aumentou muito e a estrutura acabou cedendo, obrigando a família a refazer a intervenção para promover reforços estruturais. Segundo esse coordenador, os sindicatos hoje procuram evitar este tipo de problema através de uma postura bastante criteriosa a respeito das reformas (informação verbal) ${ }^{62}$. Nos casos em que o coordenador de habitação considera possível e seguro realizar a reforma, ele desenha um esboço a partir das modificações que a família pretende fazer em sua casa e o envia aos engenheiros da filial estadual da Cooperhaf, que irão fazer o projeto de reforma e o orçamento. Portanto, nos casos de reforma, cada família terá um projeto arquitetônico e um orçamento individualizado.

\footnotetext{
${ }^{61}$ Estes valores, assim como os da linha abaixo referentes a contrapartida do agricultor, são referentes ao período do trabalho de campo, setembro de 2015 , quando o recurso disponível era de $\mathrm{R} \$ 28.500$. Atualmente, com o aumento do preço dos materiais de construção e a recente revisão dos valores do programa em junho de 2016, estes orçamentos devem ter sido atualizados pela cooperativa.

62 Informante 5, em entrevista à autora em setembro de 2015.
} 
$\mathrm{Na}$ reunião do grupo de famílias em que ocorre a assinatura do contrato - tanto de construção como de reforma - estão presentes representantes da Cooperhaf, do sindicato local e também representantes das lojas de materiais de construção. A Cooperhaf instrui os lojistas quanto à forma de funcionamento do programa, e as famílias passam a conhecê-los. Após este momento, os agricultores têm cerca de dez dias para escolher qual ou quais lojas irão lhes fornecer todos os seus materiais. Por vezes as famílias se reúnem para comprar todos na mesma loja e conseguir barganhar preços ou produtos, mas o mais comum é cada família operar de maneira independente, sem cooperação. Assim que a família define em qual estabelecimento irá comprar os materiais, elas o indicam para o sindicato, e este recolhe seus dados para realização dos pagamentos e emissão de comprovantes fiscais. O sindicato e a Cooperhaf orientam o agricultor para comprar todos os materiais na mesma loja, ou no máximo em duas, para tornar mais fácil a quitação das notas fiscais. Nesse momento, os agricultores também já devem ter definido quem será o pedreiro ou responsável pela mão-de-obra de sua casa. Para efeito de registro e pagamento, as famílias precisam indicar o CPF do pedreiro, no caso de pessoa física, ou CNPJ, no caso de o responsável pelas obras ser uma pessoa jurídica.

Figura 8: Interface online do Sistema de Informação da Cooperhaf

Fonte: disponível em < http://intranet.cooperhaf.org.br/sistema/> acesso em 06/02/2017

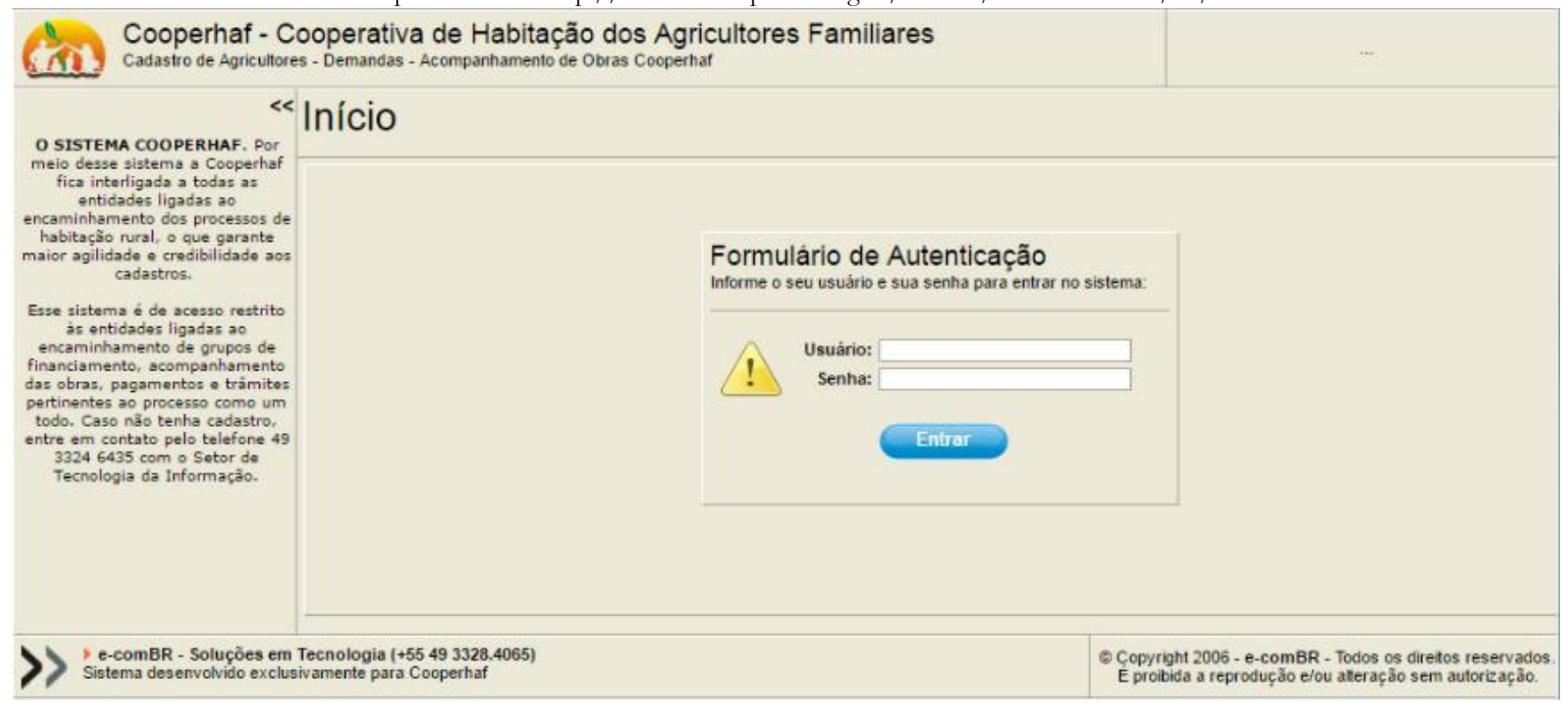

A Cooperhaf consolida todas as informações relativas a todas as obras - as que estão para contratar, em andamento e concluídas - através do Sistema de Informação da Cooperhaf (Sistema de Gestão da Habitação Rural). Este sistema foi idealizado pela cooperativa em 2006 e desenvolvido por uma empresa terceirizada, que até hoje presta serviços à cooperativa para efetuar constantes melhorias em suas funcionalidades). Trata-se de uma plataforma de dados online, que é acessada em cada instância de organização da cooperativa por um login e senha individuais. Ao entrar, cada login dá 
acesso às informações que lhe interessam na realização de determinados procedimentos. $\mathrm{O}$ registro inicial de cada família acontece no sindicato local, onde o coordenador municipal cadastra os camponeses que irão acessar o programa. Assim, as informações, inseridas no sistema, ficam disponíveis para que a secretária da filial estadual da cooperativa acesse-as e faça a triagem de todas as informações, direcionando cada uma delas para os setores a que concernem: engenharia, social, analista documental etc. Ao longo da obra, as fotografias das medições são também inseridas no sistema pelo coordenador municipal, assim como o preenchimento da Planilha de Liberação de Serviço (PLS); as planilhas que devem ser entregues periodicamente à CEF, portanto, são automaticamente geradas pelo sistema, assim como os relatórios de vistoria. Através desta plataforma online, a matriz pode ter acesso a toda essa movimentação a qualquer momento.

\subsubsection{O trabalho social da Cooperhaf}

Desde 2006 a Cooperhaf desenvolve o projeto "Caprichando a Morada", um trabalho de formação dos associados do Sintraf que acessam o recurso habitacional para construção ou reforma de suas casas. Esta formação aborda quatro grandes temas relativos a 1) orientações para a autoconstrução, 2) organização em cooperativas, 3) produção de alimentos para o autoconsumo e 4) gestão da propriedade. Os assuntos trabalhados, portanto, vão para além da questão da habitação em si e se aproximam de um momento formativo do próprio sindicato e sua federação.

Quando passou a atuar enquanto Entidade Organizadora no âmbito do programa MCMV, a Cooperhaf manteve a utilização da metodologia do "Caprichando a Morada" no desenvolvimento do trabalho social (TS), que desde então passou a ser obrigatório para os programas de habitação rural. No caso do PNHR, o TS é obrigatório apenas para os contratos realizados no âmbito do G1 e G2. A regulamentação do TS é dada pela Portaria $n^{\circ} 21$, de 22 de janeiro de 2014, cujo capítulo V trata especificamente dos procedimentos relacionados ao PNHR. Esta normativa prevê sua realização em três etapas diferentes - quais sejam: pré-obra, durante a obra e pós-ocupação - e determina três grandes eixos de temas a serem trabalhados nas atividades: mobilização e organização comunitária, educação sanitária e ambiental e geração de trabalho e renda.

O material didático utilizado pela Cooperhaf para a realização do TS, portanto, não se resume a estes temas. Consiste em quatro cadernos metodológicos, e o conteúdo de cada caderno é trabalhado em cada uma das reuniões do trabalho social exigidas no programa. Quem conduz as reuniões é o coordenador de habitação do Sintraf. Quando a obra das casas está concluída, é realizado o "Dia na Propriedade", um evento de comemoração, realizado na casa de uma das famílias que participaram do processo. 
Figura 9: páginas do Caderno 1 "Orientações para a construção habitacional" do projeto "Caprichando a Morada"

Use a colher de pedreiro para posicionar os blocos. Raspe a argamassa que sobrar, para ser reaproveitada.
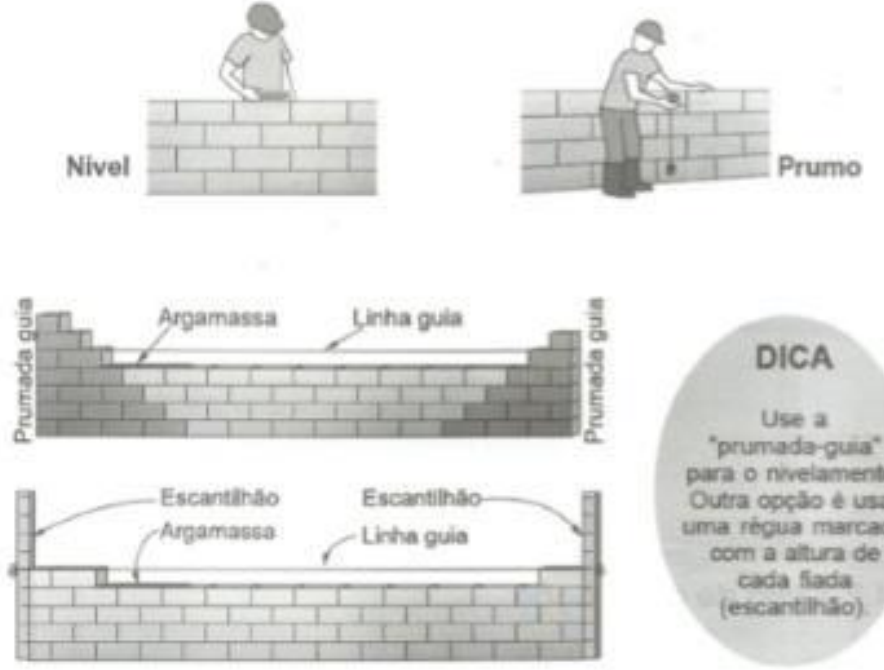
para o nvelamento. Outra opelo e usar uma recua marcacia

com a altura de

cada flada

(escantilinso)

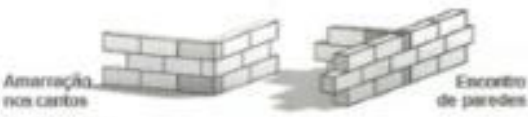

Encout

ton thingen

ton tistion

texcartina

\subsubsection{Váos de portas e janelas}

Use uma verga na primeira feda de biocos acina do vilo. Essa verga pode ser pré-moldada ou feita no local. Ela deve ter, no minimo, $20 \mathrm{~cm}$ a mais para cada lado do vảo. NBo se esqueça tambèm de escorar as fồrmas das vergas concretadas no prógrio local.

Os conteúdos do Caderno 1, “Orientações para a construção habitacional”, são trabalhados na primeira reunião após a assinatura do contrato com o grupo. O trabalho com este caderno tem o objetivo de capacitar os agricultores a construírem a própria casa, ou ao menos obterem noções básicas para poderem acompanhar as obras ${ }^{63}$. O texto introdutório ao primeiro caderno deixa claro a intenção da Cooperhaf em motivar os associados a optarem pela autoconstrução:

${ }^{63}$ A obra é visitada pelo coordenador de habitação do Sintraf uma vez por semana, e todos os entrevistados indicaram que o acompanhamento diário deve ser feito pelas famílias, o que tem funcionado. 
A construção do local onde iremos habitar, principalmente no meio rural, é uma decisão muito importante e à qual está ligada uma série de consequências. A proximidade do trabalho diário, a posição solar, o tipo de solo, os recursos físicos, materiais e financeiros que serão necessários, são fundamentais para que a moradia não se transforme num pesadelo para quem constrói.

Há também o custo de cada obra, que vai determinar o tamanho da casa e a qualidade dos acabamentos. Algumas decisões são muito importantes para economizar na hora da construção, sempre ciente que precisa ser uma moradia segura, higiênica e confortável. A ideia de construir casas de maneira coletiva, seja no sistema mutirão ou de autoconstrução assistida, também é uma alternativa bastante viável para o homem do campo, porque racionaliza a mão-de-obra e aproveita muitos recursos que estão à disposição na propriedade.

Pensando nisso, elaboramos este caderno. Para que vocês, agricultor ou agricultora possa arregaçar as mangas e juntamente com sua família ou com vizinhos, construir a sua moradia. A tarefa não é fácil, mas com a ajuda de alguns profissionais da Cooperhaf e um pouco de criatividade e cooperação, todos podem ter um bom lugar para morar [...] (COOPERHAF, 2008a, p. 09, grifo nosso).

Os conteúdos deste primeiro caderno, ricamente ilustrado com figuras retiradas de uma cartilha da Associação Brasileira do Cimento Portland (ABCP), utilizam uma linguagem para leigos no assunto, e passam pelos mais diversos temas relacionados à construção de uma casa: desde explicações básicas como posição dos cômodos em relação ao sol e o significado de cada unidade de medida (perímetro, área, volume) até informações sobre a execução de cada etapa da obra, incluindo dicas para escolha e recebimento dos materiais de construção.

O Caderno 2 tem como título "Organização, cooperativismo e associativismo na agricultura familiar", e foca o conteúdo da formação na importância da organização política das famílias, especialmente junto ao sindicato e na formação de cooperativas e associações "que venham a contribuir para o enfrentamento dos problemas do dia-a-dia no campo" (COOPERHAF, 2008b, p. 9). O texto conta a história da luta dos agricultores sindicalizados no Brasil, a criação da categoria "trabalhadores rurais" e o quanto consideram importante a distinção entre estes e os "Agricultores Familiares", já que possuem "interesses muito diferentes e em certo ponto contraditórios" (COOPERHAF, 2008b, p.12).

As principais reivindicações dos assalariados são a melhoria dos seus salários, carteira assinada, condições dignas de trabalho, entre outras.

Já o agricultor e agricultora familiar busca melhorias para sua produção, como: crédito, assistência técnica, melhores preços, infraestrutura, moradia, saúde, educação... entre tantas necessidades. Além disso, muitos agricultores familiares contratam trabalhadores assalariados, mesmo que em alguns períodos durante o ano (p. 12). 
Na sequência é apresentada a Fetraf, suas lutas, conquistas e lemas, através de uma linguagem coerente e de fácil assimilação.

O Caderno 3, "Construindo um ambiente saudável e sustentável" é um guia para a execução de cultivos não comerciais no entorno da casa: a horta doméstica, o canteiro de plantas medicinais, o pomar e as instalações que demandam. Além disso, também são tratados os temas relativos à obtenção de agua potável, destinação dos efluentes e do lixo seco e orgânico. São reforçados os conceitos de reciclagem, compostagem e produção diversificada, com um apelo ao planejamento da propriedade.

O último Caderno, "Gestão financeira e social da propriedade" destaca a conexão intrínseca entre o bom andamento da produção e dos negócios na propriedade e a relação entre os integrantes da família. São colocados no debate as particularidades da mulher, das crianças, dos jovens e do idoso na vida da família e na produção agropecuária familiar.

\subsubsection{O canteiro de obras}

A construção das casas dos agricultores - o objetivo final do arranjo adotado para operacionalização da parceria Cooperhaf/Sintraf - é similar em todos os municípios catarinenses visitados. A padronização dos procedimentos práticos demandados foi forjada e é mantida e controlada cuidadosamente pela direção da Cooperhaf, basicamente através de reuniões semestrais de formação com todos os coordenadores municipais de habitação do estado e através do permanente tratamento dos dados obtidos por intermédio do "Sistema de Informação da Cooperhaf". Em relação aos associados, para que seja assegurada essa padronização de procedimentos, a direção da cooperativa conta justamente com os conteúdos trabalhos nas reuniões do TS - uma outra funcionalidade do material didático produzido pela organização.

\subsubsection{O material: o lojista amigo}

Desde o primeiro município visitado no trabalho de campo, ficou claro que a loja de materiais de construção exercia papel central no arranjo Cooperhaf/Sintraf. Por esse motivo, passamos a entrevistar também os proprietários ou funcionários das lojas da cidade - um expediente que não havia sido previsto inicialmente.

O valor destinado para a compra dos materiais e pagamento de mão-de-obra não é controlado diretamente pelos camponeses, nem pelo sindicato. Assim que o grupo de famílias é formado, é eleita a Comissão de Representantes (CRE) - da qual participam dois representantes das famílias e um integrante da Entidade Organizadora - que irá abrir uma conta na CEF. Assim que as parcelas dos recursos vão sendo creditadas nesta conta da CRE, a filial da Cooperhaf - que, lembremos, atua aqui 
como uma Entidade Organizadora e, portante, participante da CRE - é quem realiza os pagamentos das compras realizadas nas lojas cadastradas e da mão de obra contratada de acordo com as faturas, notas e recibos fornecidos por cada um deles.

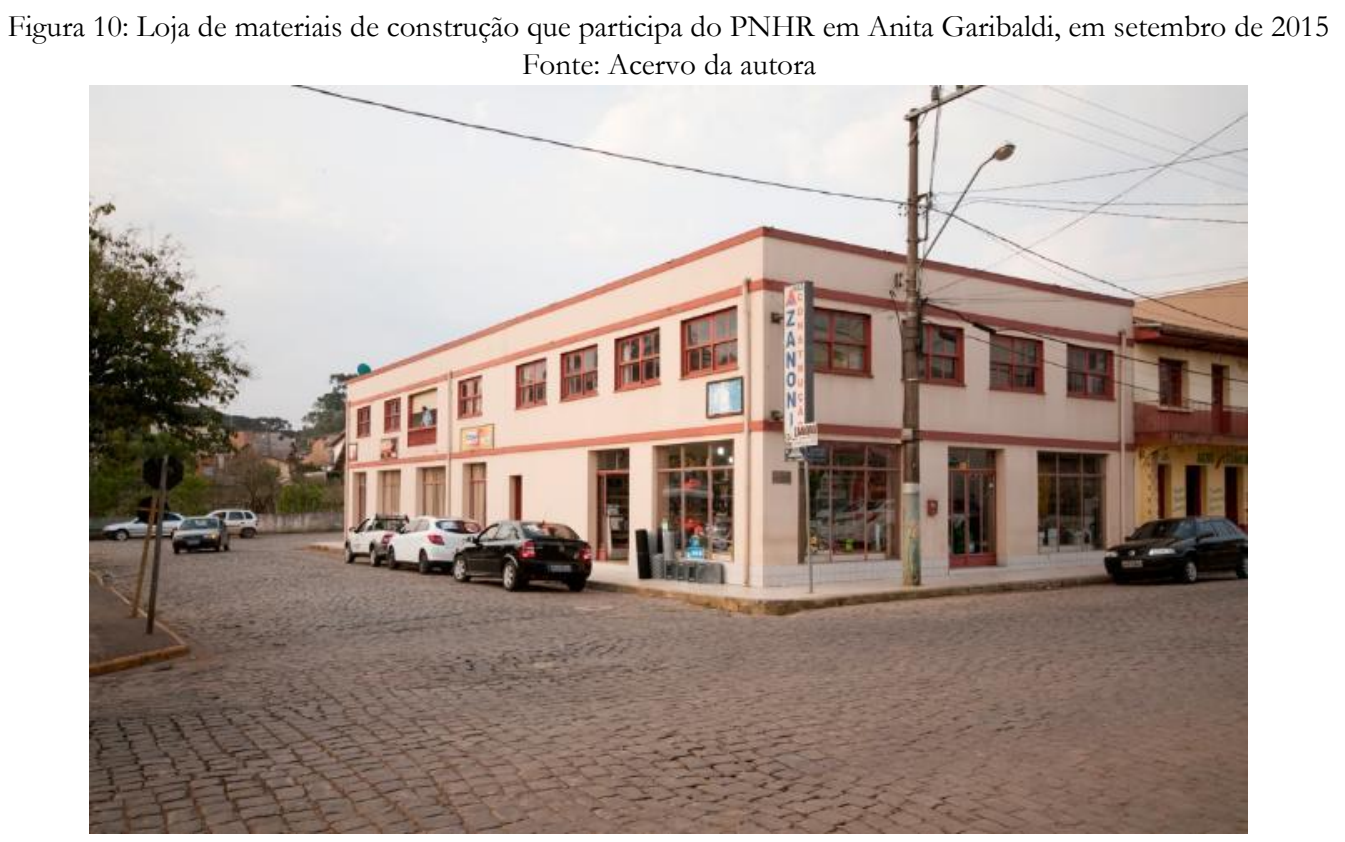

O valor referente ao material de construção é previamente acertado com as lojas: eles recebem da Cooperhaf o orçamento e o memorial descritivo de cada um dos modelos, verificam a possibilidade de fornecimento da totalidade dos materiais listados dentro do preço indicado, incluindo as especificações de qualidade e quantidade, e, caso considere economicamente viável, aceitam ser fornecedores naquele município. Assim que o contrato com a CEF é assinado, o lojista emite para cada família uma "nota de venda para entrega futura" com o valor cheio da compra (muitas vezes equivalente ao valor total da casa), mediante a qual a CRE fará os pagamentos, conforme as medições de obra e as liberações de verbas vão acontecendo.

Usualmente as famílias vão às lojas, antes do início das obras, para escolher os acabamentos: modelo das louças, modelo e cor dos pisos e azulejos, gabinetes da cozinha etc. Alguns ficam com a linha "básica", mais barata, mas muitos - a maioria, segundo todos os lojistas entrevistados $\left(\right.$ informação verbal ${ }^{64}$ ) - acabam complementando o valor para adquirir peças com qualidade superior ou "mais do gosto da família". Visitamos uma casa que estava sendo construída pelo futuro morador em regime de autoconstrução, na qual apenas em material havia sido gasto pelo menos $50 \%$ a mais do valor do subsídio, montante complementado pelo agricultor. Essas complementações nos

${ }^{64}$ Informantes 2 e 3 em entrevista à autora em setembro de 2015. 
materiais geralmente são feitas com reservas que a família já vinha fazendo há algum tempo para melhorias na casa, ou então através da venda de alguns animais, ou mesmo devido a uma boa safra.

Com o início das obras, os lojistas também dão início à entrega dos materiais; muitos relataram que, das primeiras vezes que forneceram material para as casas do PNHR, enviavam tudo de uma só vez. Porém, os atrasos no pagamento - inclusive da primeira liberação, equivalente a $15 \%$ do valor contratado -, fizeram alguns lojistas mudar o procedimento; passaram a enviar o material por etapas e apenas mediante pagamento da parcela anterior. Mesmo assim, até lojas de maior porte apresentavam dificuldades no fluxo do fornecimento dos materiais, já que os atrasos nos pagamentos, em setembro de 2015, continuavam se acumulando sistematicamente.

Em alguns municípios, os atrasos na liberação dos recursos acabaram onerando a família, que precisava cobrir a diferença de preço gerada entre a data que o produto foi entregue e a data que foi pago. Para evitar este tipo de problema, os sindicatos recomendam que, já na primeira liberação de verba, sejam comprados os materiais que têm maior oscilação de preço.

Os cronogramas de obra aprovados na CEF previam, à época, um prazo de quatro meses para duração das obras. Porém, como em qualquer obra, a execução dos trabalhos depende da entrega dos materiais que, por sua vez, depende dos pagamentos. Os camponeses que tinham necessidade de ter a casa pronta com urgência e possuíam alguma reserva financeira chegavam a adiantar o valor dos materiais de construção para o lojista que, assim, os liberava com antecedência; assim que a CEF liberava as parcelas seguintes e quitava o valor total dos materiais fornecidos, a loja devolvia para o agricultor a totalidade do valor por ele adiantado (nesses casos, as partes firmavam contratos registrados em cartório comprovando a realização da transação).

Uma das conversas com o proprietário de uma loja de materiais foi particularmente significativa e colaborou para a compreensão da centralidade que este agente exerce neste arranjo. Naquele momento a loja estava fornecendo materiais para oito obras do programa. Mas, desde o começo do PNHR/MCMV, essa mesma loja chegou a fornecer material para 34 casas ao mesmo tempo. Dado os conhecimentos do lojista em construção civil somado ao fato da loja fornecer todos os materiais para obras relativamente padronizadas, permite àquele ter uma visão do todo e poder, dessa forma, interferir quando algo lhe parecer fora do comum. No caso desta loja, o proprietário demonstrava preocupação e responsabilidade sobre os materiais que seriam utilizados em cada obra; considerava que, se algo desse errado na construção, se sentiria culpado. Comentava, inclusive, não admitir que os agricultores levassem menos insumos para a estrutura da casa do que o previsto coisa que fariam para poder, com esta economia, adquirir materiais de acabamento de melhor qualidade. 
Quantas pessoas queriam fazer só com duas barrinhas de ferro lá [na cinta de amarração]. Não aceito, eu não forneço. Quando nós fizemos reunião com a Caixa e a Cooperhaf, eles foram muito claros, tem que ser assim, assim, assado. E o povo, como é mais simples, não querem gastar, querem economizar... [falamos pra eles que] isso [o PNHR] é uma coisa do sindicato, da caixa, da Cooperhaf, nós vamos seguir as normas deles e vocês vão receber a casa de vocês (informação verbal) ${ }^{65}$.

O lojista faz, inclusive, uma análise a respeito das mudanças na cultura construtiva da região a partir da entrada dos programas habitacionais do governo: afirma que agora predominam outros materiais e outros sistemas construtivos.

Essa coisa de verga e contra-verga, se conheceu quando se implataram isso [programas habitacionais], não tinha um ferrinho lá em cima para não cair.

[Não usavam e] de vez em quando aparecia uma rachadura! Veio a conhecimento do pessoal quando começou esses programas da Caixa! Tanto que na época nós vendíamos casa, e cimento era raro usar. Usava barro. Casa de barro, tijolo maciço cozido [...] Essa igreja aqui na frente, não tem ferro nenhum, é só tijolo maciço (informação verbal) ${ }^{66}$.

As dificuldades enfrentadas pelas lojas no fornecimento dos materiais para as casas do PNHR referem-se principalmente aos atrasos nos pagamentos. O mesmo lojista conta que naquele momento, setembro de 2015, algumas parcelas de 2012 ainda não haviam sido pagas pela CEF, e relembra que o preço que será pago pelo produto, quando o for, será o de 2012, sem correção. E se ele, por um lado, quer "manter o nome" da loja na cidade e honrar com as entregas para que as casas sejam construídas, por outro lado a filha, que trabalha na administração da loja junto ao pai, não pretende assumir o fornecimento de mais materiais de construção para os programas do governo federal. Ela garante que com estas vendas "deu para empatar", mas que não realizaram lucro algum. "A gente foi muito... você [corrigindo-se e apontando para o pai] foi muito maleável em entregar, eu dizia 'não entregue', e o pai, de dó de deixar as casas paradas, entregava, e eu dizia, só entregue se receber, e ele ia lá e entregava" (informação verbal) ${ }^{67}$. O que ainda mantém este lojista como fornecedor para as obras do PNHR no município é sua proximidade com os clientes, o que implica a sua incapacidade de aplicar as regras do mercado. "A parte que eu mais fiquei feliz foi de ver famílias que eu conheci numa miséria só, e morando hoje. Vou tomar chimarrão com os caras lá na casa deles hoje. Apesar de eles estarem me devendo! [Risos] Fazer o que" (informação verbal) ${ }^{68}$.

\footnotetext{
${ }^{65}$ Informante 2, em entrevista à autora em setembro de 2015.

${ }^{66}$ Informante 2, em entrevista à autora em setembro de 2015.

${ }^{67}$ Informante 3, em entrevista à autora em setembro de 2015.

${ }^{68}$ Informante 2, em entrevista à autora em setembro de 2015.
} 


\subsubsection{A mão-de-obra: "todo agricultor tem um pouco de pedreiro"}

A afirmação “todo agricultor tem um pouco de pedreiro" (informação verbal) ${ }^{69}$, feita por um dos coordenadores municipais de habitação, suscita muitas reflexões para nossa pesquisa. Nas obras visitadas durante o trabalho de campo, o regime de construção variou entre autoconstrução, contratação de amigos ou familiares e contratação de pedreiros indicados (sem relações pessoais anteriores). Alguns coordenadores municipais incentivam também um regime misto, que envolve a contratação de um pedreiro e a participação do futuro morador como servente, como forma de reduzir um pouco os gastos com mão-de-obra.

Tabela 14: Proveniência da mão-de-obra das obras visitadas no trabalho de campo Fonte: elaborado pela autora a partir das informações obtidas em campo

\begin{tabular}{ccccc}
\hline SANTA & IRANI & $\begin{array}{c}\text { ANITA } \\
\text { TEREZINHA }\end{array}$ & $\begin{array}{c}\text { ALFREDO } \\
\text { WAGNER }\end{array}$ & ITUPORANGA \\
\hline Próprio morador & $\begin{array}{c}\text { Contratação de } \\
\text { mão-de-obra } \\
\text { profissional }\end{array}$ & Vizinho & Próprio morador & $\begin{array}{c}\text { Cunhado do } \\
\text { morador }\end{array}$ \\
\hline
\end{tabular}

Como vimos, o regime de autoconstrução no PNHR é altamente estimulado pela Cooperhaf e muitas vezes é a única forma de garantir que o recurso financeiro fornecido pelo programa seja suficiente para a finalização da obra - apesar de, lembramos, não se tratar de um processo de trabalho compatível com o modo de vida de uma família de agricultores. Apesar disso, as regras do programa indicam que quem recebe o dinheiro reservado para a mão-de-obra não pode ser o próprio beneficiário. Isso demonstra uma contradição interna, já que o próprio programa prevê a autoconstrução assistida como regime de construção. Pressupõe-se, portanto, que o programa prescreve implicitamente a utilização de mão de obra não remunerada.

Os valores destinados para o pagamento da mão-de-obra são variáveis. Dentro do arranjo da Cooperhaf, $30 \%$ do orçamento de cada modelo de casa fica reservado para o pagamento dos pedreiros, mas o que é efetivamente pago varia de acordo com o regime de construção e depende dos acordos entre o pedreiro e a família. Porém, na quase totalidade dos casos consultados, o valor efetivamente pago à mão-de-obra excedeu esta previsão.

Mesmo que a casa seja construída pelo beneficiário, a instalação elétrica é sempre realizada por um especialista contratado especificamente para este serviço. É comum também os camponeses contratarem à parte o serviço especializado de pintura e de execução de calhas. O maior impedimento para as famílias utilizarem sua própria mão-de-obra na construção da casa é a incontornável necessidade de se dedicarem à lavoura durante os períodos de safra, como comentado anteriormente. Se as obras têm início na entressafra, é comum o camponês ao menos exercer a função de servente

\footnotetext{
${ }^{69}$ Informante 4, em entrevista à autora em setembro de 2015.
} 
de pedreiro durante a obra, como forma de reduzir os custos com a mão-de-obra. É comum também, nestes casos de pressa devido ao curto período da entressafra, o camponês adiantar o pagamento dos materiais de construção, de forma a receber todo o material e finalizar a construção da casa antes que tenha que dar início novamente ao plantio.

Quando o regime de construção escolhido leva à contratação de mão-de-obra, a maior parte dos pedreiros contratados é da própria região. A disponibilidade de mão-de-obra para construção civil dentro do próprio campesinato parece ser comum, tanto nos casos em que o camponês exerce o trabalho acessório durante a entressafra quanto - e principalmente - nos casos das famílias vinculadas aos sistemas de integração ${ }^{70}$. Neste caso, essa disponibilização de mão-de-obra familiar acontece porque, após a entrega da produção para a empresa integradora, normalmente os camponeses levam meses até receberem sua remuneração; porém, como "as contas são pagas por mês", o marido acaba tendo que trabalhar como pedreiro, enquanto a mulher segue na propriedade nas outras tarefas (informação verbal $^{71}$. Outros depoimentos reforçaram, contudo, que o aumento na demanda por mão-de-obra nos municípios, inclusive devido ao PNHR, fez valorizar a diária do pedreiro e, também por isso, muitos agricultores "se tornaram" também pedreiros.

O sistema construtivo das casas é convencional: de vigas e pilares de concreto com vedação em blocos cerâmicos (estrutura mista). A cobertura é de telhas cerâmicas sobre madeiramento tradicional. O projeto padrão indica forro de madeira, mas algumas famílias usam forro de PVC ou executam laje. A fundação é de sapatas isoladas que apoiam vigas baldrames. Dependendo das características do solo, são executadas fundações profundas (estacas) que não estão contabilizadas no orçamento e, por isso, acabam representando um gasto extra. O projeto prevê contrapiso sobre lastro de brita, mas as unidades que foram construídas em declividades acentuadas executaram laje - o que também faz aumentar o valor final da casa.

\subsubsection{O canteiro: ferramentas e materiais de construção}

O ferramental utilizado nos canteiros de obras não difere significativamente entre os municípios visitados. Todos os canteiros são servidos por energia elétrica, permitindo a utilização de equipamentos como betoneira, furadeira, serra tico-tico e circular etc. Tivemos notícia de um canteiro de obras que utilizou concreto usinado para a concretagem da laje, o que configura verdadeira exceção dentre os demais casos - nos quais o concreto é preparado manualmente, apenas com a ajuda de enxadas e pás, sem controle mais apurado de dosagem.

\footnotetext{
${ }^{70}$ Conforme explicado na nota número 29, na página 35.

${ }^{71}$ Informante 1, em entrevista à autora em setembro de 2015
} 
A proveniência dos materiais e insumos utilizados na construção das casas segue um padrão em todos os municípios. Os que implicam trabalho majoritariamente artesanal são de proveniência local, como o bloco cerâmico, a telha cerâmica e a areia. Já os de origem industrial são fabricados por grandes empresas e costumam ser das mesmas marcas, ou de marcas similares. Deve-se fazer destaque para o cimento, o aço e a louça, que em todos os casos são da mesma empresa: Votoran, Gerdau e Belgo (Acelor) e Logasa, respectivamente. A Tabela 15 resume estas informações.

Porém, fica por conta do camponês decidir a forma de aquisição de cada material e insumo, que pode ser comprado nas lojas ou extraído do próprio lote, desde que respeite o memorial descritivo elaborado pela Cooperhaf. É possível, por exemplo, a utilização de madeira proveniente do próprio lote ou mesmo de brita, caso disponível. No entanto, para registrar esta opção e preservar responsabilidades, a Cooperhaf exige que a família faça uma declaração registrada em cartório. Em outras palavras, há um controle que restringe consideravelmente os materiais e as quantidades que são usadas em cada obra; a família não tem liberdade para construir sem brita ou com menos ferragem do que o pré-estabelecido, por exemplo. Se, por um lado, tal exigência atende a um requisito pertinente de segurança das edificações, por outro lado acaba cerceando alguma possibilidade de adoção de sistemas de construção tradicionais consolidados no país - como a utilização de terra ou de rachão como material construtivo, por exemplo.

Tabela 15: Proveniência dos materiais e insumos utilizados nos canteiros de obras do PNHR em SC. Obs.: Entre parênteses consta a distância do local de produção do insumo, quando relevante.

\begin{tabular}{|c|c|c|c|c|c|}
\hline & $\begin{array}{c}\text { SANTA } \\
\text { TEREZINHA }\end{array}$ & IRANI & $\begin{array}{c}\text { ANITA } \\
\text { GARIBALDI }\end{array}$ & $\begin{array}{l}\text { ALFREDO } \\
\text { WAGNER }\end{array}$ & ITUPORANGA \\
\hline $\begin{array}{c}\text { bloco } \\
\text { cerâmico }\end{array}$ & local & $\begin{array}{l}\text { local / pouso } \\
\text { redondo }(250 \mathrm{~km})\end{array}$ & $\begin{array}{l}\text { Pouso Redondo } \\
(180 \mathrm{~km})\end{array}$ & Canelinha (130) & local \\
\hline $\begin{array}{c}\text { telha } \\
\text { cerâmica }\end{array}$ & $\begin{array}{l}\text { Morro da Fumaça } \\
(400 \mathrm{~km})\end{array}$ & 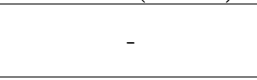 & Criciúma (320km) & Sangão (210km) & \multirow{2}{*}{ Agrolândia (20km) } \\
\hline $\begin{array}{c}\text { telha } \\
\text { esmatada }\end{array}$ & Rio Negro (100km) & Urussanga (420km) & - & $\begin{array}{c}\text { Cejatel, de } \\
\text { Guabiruba }(150 \mathrm{~km})\end{array}$ & \\
\hline $\begin{array}{c}\text { telha } \\
\text { concreto }\end{array}$ & - & $\begin{array}{l}\text { Faxinal dos Guedes } \\
(62 \mathrm{~km})\end{array}$ & - & (2) & - \\
\hline areia fina & \multirow{3}{*}{$\begin{array}{l}\text { Pouso Redondo } \\
\qquad(100 \mathrm{~km})\end{array}$} & \multirow{2}{*}{$\begin{array}{l}\text { União da Vitória } \\
\qquad(140 \mathrm{~km})\end{array}$} & \multirow{2}{*}{$\begin{array}{l}\text { Vale do Itajaí } \\
\quad(360 \mathrm{~km})\end{array}$} & \multirow{2}{*}{$\begin{array}{c}\text { Santo Amaro da } \\
\text { Imperatriz }(90 \mathrm{~km})\end{array}$} & $\begin{array}{c}\text { Paulo Lopes } \\
(180 \mathrm{~km})\end{array}$ \\
\hline areia média & & & & & $\begin{array}{l}\text { Guaramirim } \\
(170 \mathrm{~km})\end{array}$ \\
\hline brita & & local & Lages $(110 \mathrm{~km})$ & Vidal Ramos & Vidal Ramos \\
\hline cimento & $\begin{array}{l}\text { Vidal Ramos } \\
(200 \mathrm{~km})\end{array}$ & $\begin{array}{c}\text { Vidal Ramos } \\
(340 \mathrm{~km})\end{array}$ & $\begin{array}{l}\text { Vidal Ramos } \\
(300 \mathrm{~km})\end{array}$ & $\begin{array}{l}\text { Vidal Ramos } \\
(70 \mathrm{~km})\end{array}$ & $\begin{array}{l}\text { Vidal Ramos } \\
(35 \mathrm{~km})\end{array}$ \\
\hline PVC & Krona & Tubosan / Plastubo & Krona & Krona & Krona \\
\hline aço & Gerdau e Belgo & Gerdau e Belgo & Gerdau e Belgo & Gerdau e Belgo & Gerdau e Belgo \\
\hline $\begin{array}{l}\text { revestimentos } \\
\text { cerâmicos }\end{array}$ & $\begin{array}{c}\text { Savani (SP), } \\
\text { Almeida (SP), Lumi } \\
(\mathrm{SP}), \text { Delta (SP) }\end{array}$ & $\begin{array}{l}\text { Cristofoletti (SP) } \\
\text { Angelgres (SC) }\end{array}$ & Criciúma & $\begin{array}{c}\text { Cristofoletti (SP), } \\
\text { Cejatel (SC) e } \\
\text { Embramaco }\end{array}$ & Cejatel e Pisoforte \\
\hline louças & Logasa & Logasa & Logasa & Logasa e Incepa & Logasa \\
\hline
\end{tabular}

Não foram encontradas informações sistematizadas a respeito das modificações das casas durante a pós-ocupação. Porém, em diversos relatos ficou clara a prévia intenção de alterar a 
organização interna da casa já no momento de sua construção. Em um dos municípios, inclusive, houve casos de modificação antes do encerramento do contrato, o que é proibido pelas normas da CEF: a casa deve ser concluída conforme o projeto aprovado. Em um dos municípios estudados o coordenador de habitação acabou criando uma penalização, em forma de multa, para as famílias que promovessem modificações na obra antes da finalização do contrato.

Eu até brinco, depois que finalizar a obra tu faz o que quiser, se quiser desmanchar [a casa] inteira e fazer uma nova, fica a vontade, não tem problema, mas [agora] faça como está na planta.

E o pessoal tem modificado as casas que já estão prontas?

Bastante. Não sei o porque, mas modifica. Até durante a obra, nesse último grupo não tive problema, mas em 2013 o pessoal estava modificando sem vir falar comigo, alterava por conta. Daí a CEF trancava o grupo... Aí a gente baixou uma lei de que, se tivesse alteração na planta, seria cobrada nova planta, daí o pessoal entendeu (informação verbal) ${ }^{72}$.

${ }^{72}$ Informante 6, em entrevista à autora em setembro 2015 


\section{$3^{\circ}$ CAPÍTULO: A produção da casa camponesa}

A partir da contextualização histórica das organizações sindicais no Brasil e da compreensão geral da execução do PNHR, este terceiro capítulo encerra o trabalho com uma interpretação sobre a produção da moradia camponesa a partir da perspectiva teórica da criação e recriação do campesinato no seio do capitalismo. Procuramos indicar que a habitação camponesa participa do modo de vida camponês enquanto item da produção para o autoconsumo da família e, na sequencia, analisamos alguns aspectos do PNHR/MCMV sob a perspectiva do processo de submissão do campesinato ao capital.

\subsection{A habitação como produto do autoconsumo camponês}

"Mesmo que o mundo sensível, como em São Bruno, seja reduzido a um cajado, a um mínimo, ele pressupõe a atividade de produção desse cajado" (MARX, 2007, p.33).

A perspectiva teórico-metodológica desta dissertação foi tomando forma ao longo do desenvolvimento de cada uma das etapas. O método que rege este trabalho encontra-se fundamentado no materialismo histórico, que foi desenvolvido por Karl Marx e Friedrich Engels e defendido pela primeira vez no livro "A Ideologia Alemã”, quando os autores refutam a concepção idealista da realidade, como defendida por Feuerbach:

Ele não vê como o mundo sensível que o rodeia não é uma coisa dada imediatamente por toda a eternidade e sempre igual a si mesma, mas o produto da indústria e do estado de coisas da sociedade, e isso precisamente no sentido de que é um produto histórico, o resultado da atividade de toda uma série de gerações [...] (MARX, 2007, p. 30).

Os autores indicam, portanto, uma determinada maneira de interpretar o mundo e, do ponto de vista da pesquisa científica, essa maneira nos impele a entender o fenômeno estudado a partir da compreensão de seu surgimento, sua origem física e concreta: sua produção.

O método materialista dialético pressupõe que “[...] só é possível conquistar a libertação real no mundo real e pelo emprego de meios reais” (MARX, 2007, p. 29). O primeiro ato histórico será, então, a produção dos meios de vida necessários para que este indivíduo esteja em condições de tal tarefa libertadora. Nesta perspectiva,

[...] os homens têm de estar em condições de viver para poder 'fazer história'. Mas, para viver, precisa-se, antes de tudo, de comida, bebida, moradia, vestimenta e algumas coisas mais. O primeiro ato histórico é, pois, a produção dos meios para a satisfação dessas necessidades, a produção da própria vida material, e este é, sem dúvida, um ato histórico, uma condição fundamental de toda a história, que ainda hoje, assim como há milênios, tem 
de ser cumprida diariamente, a cada hora, simplesmente para manter os homens vivos (MARX, 2007, p. 32-3).

Consideramos, assim, o processo de produção dos meios de vida do campesinato como perspectiva privilegiada de estudo. O problema dos meios de vida será o objeto central da análise de Antônio Cândido acerca do modo de vida do caipira, em seu livro "Os Parceiros do Rio Bonito". O autor define este objeto como o "ponto de partida situado no nível modesto mas decisivo da realidade econômica" (CÂNDIDO, 2010, p. 21). Explorando os limites do significado do mínimo e das necessidades, o autor reflete sobre o alcance do equilíbrio social a partir do equilíbrio entre os "mínimos vitais de alimentação e abrigo, e os mínimos sociais de organização para obtê-los e garantir a regularidade das relações humanas" (p. 31). Assim, a vida social do caipira:

[...] assimilou e conservou os elementos condicionados pelas suas origens nômades. A combinação dos traços culturais indígenas e portugueses obedeceu ao ritmo nômade do bandeirante e do povoador, conservando as características de uma economia largamente permeada pelas práticas de presa e coleta, cuja estrutura instável dependia da mobilidade dos indivíduos e dos grupos. Por isso, na habitação, na dieta, no caráter do caipira, gravou-se para sempre o provisório da aventura (CÂNDIDO, 2010, p. 45)

A interpretação da provisoriedade de sua habitação é exemplificada pelo autor, no limite, pela compreensão de que para o caipira "uma árvore com sombra era o bastante para um homem morar" (p. 46). Concretamente, tal provisoriedade e rudeza transfere à casa do caipira características de pouso, que chama de rancho, "um abrigo de palha, sobre paredes de pau a pique, ou mesmo varas não barreadas, levemente pousado no solo" (CÂNDIDO, 2010, p. 45). Esta rudeza e precariedade também é verificada no âmbito da dieta alimentar do caipira e será o objeto que o autor irá desenvolver ao longo de sua pesquisa, analisando as mudanças de acordo com o ajustamento ao meio que se transformava:

[...] a alimentação ilustra o caráter de sequencia ininterrupta, de continuidade, que há nas relações do grupo com o meio. Ela é de certo modo um vínculo entre ambos, um dos fatores de sua solidariedade profunda, e, na medida em que consiste numa incorporação ao homem de elementos extraídos da natureza, é o seu primeiro e mais constante mediador, lógica e por certo historicamente anterior à técnica (CÂNDIDO, 2010, p. 33).

Defendemos nesta pesquisa que, no contexto dos estudos sobre o campesinato, a habitação também se configura, assim como a dieta, como um objeto privilegiado de estudo. Em primeiro lugar, por ser considerada também uma necessidade mínima vital e, em segundo lugar, por historicamente se encontrar, da mesma forma, dentro do universo da produção para o autoconsumo camponês. Interessa-nos, portanto, defender neste capítulo que a casa camponesa deve ser 
interpretada como mais um dos itens do autoconsumo camponês e que seu processo produtivo deve ser interpretado a partir da lógica da reprodução camponesa. Não deve, portanto, ser compreendido a partir das mesmas relações de produção da habitação social urbana, exigindo assim um escopo teórico próprio que leve em consideração as particularidades desta organização social.

Mas do que estamos falando ao nos referirmos às relações de produção camponesas? Dentro do marxismo existem diversas correntes teóricas que compreendem o campesinato e sua reprodução de perspectivas bastante distintas, e que interpretam as relações sociais engendradas por estes dentro do capitalismo de diferentes maneiras. Para algumas destas correntes teóricas, por exemplo, não faria sentido procurarmos entender a produção da habitação camponesa como um dos itens do autoconsumo porque o campesinato não existe enquanto classe atualmente. Entendem que o campesinato é um elemento do passado, vestígios feudais de uma organização social extinta, e que a sua presença e de seu modo de vida não importam pois logo irão desaparecer: sucumbirão frente à generalização das relações de produção capitalistas no campo. Se estes teóricos se debruçassem sobre a questão da habitação social, certamente concluiriam que a interpretação da produção da casa camponesa não possui particularidade alguma em relação à produção da habitação social urbana, pois as relações sociais estabelecidas em ambas são idênticas. Ou eles poderiam mesmo defender que a habitação camponesa é um tema anacrônico, já que o campo foi tomado por relações de produção puramente capitalistas - tão anacrônico quanto a reforma agrária, já desnecessária para a transformação social ${ }^{73}$.

Buscamos aqui trabalhar sob outro ponto de vista, segundo o qual a habitação camponesa é um tema chave pois, assim como os demais elementos da vida camponesa, é produto da contradição gerada pelas relações não-capitalistas e capitalistas de produção, fruto do avanço do modo capitalista de produção no campo.

Esta perspectiva sobre o campesinato tem origem nos escritos de Rosa Luxemburgo do início do século XIX sobre a acumulação capitalista ${ }^{74}$. Ela indica que

\begin{abstract}
para continuar garantindo sua existência, sua expansão, e o processo contínuo de acumulação, o capital necessita, contraditoriamente, de relações não capitalistas de produção. Embora a tendência seja a de substituição da economia mercantil simples pela economia capitalista, para que o processo de acumulação primitiva continue se dando - e com ele, para além da produção do capital, continue se dando a recriação da burguesia -, essa substituição nem sempre ocorrerá. (MARCOS; FABRINI, 2010, p. 24).
\end{abstract}

\footnotetext{
${ }^{73}$ Para a compreensão das diferentes correntes de pensamentos sobre o mundo agrário recomendamos os trabalhos de Ariovaldo Umbelino de Oliveira, particularmente o texto "Geografia agrária: perspectivas no início do século XXI", publicado no livro "O campo no século XXI: território de vida, de luta e de construção de justiça social", organização de Ariovaldo Umbelino de Oliveira e Marta Inez Medeiros Marques, editora Casa Amarela e editora Paz e Terra, 2004.

74 “A acumulação do capital”, de Rosa Luxemburgo, publicado pela primeira vez em 1913.
} 
É sabido que as relações capitalistas de produção estão baseadas na separação dos trabalhadores dos seus meios de produção, o que permite a existência da igualdade jurídica, apesar da desigualdade econômica, entre o trabalhador e o proprietário dos meios de produção. Mas, como vimos anteriormente a partir das reflexões de Azis Simão e principalmente de José de Souza Martins, no campesinato esta separação não acontece - a família camponesa é proprietária de sua força de trabalho e de seus meios de produção ${ }^{75}$, e o trabalho que aplicar sobre a terra irá gerar frutos que serão vendidos como produtos acabados, próprios do camponês. Esta é essencialmente a diferença que nos permite compreender o campesinato como gerador de relações não-capitalistas de produção - o que, conforme a teoria de Rosa Luxemburgo, aparece como categoria necessária para a permanente acumulação primitiva e, assim, para a própria manutenção do capitalismo. Interessa ao capital, portanto, manter, criar e recriar estas relações não-capitalistas de produção - e assim o campesinato segue e seguirá existindo enquanto tal.

[...] o estudo da agricultura brasileira deve ser feito levando em conta que o processo de desenvolvimento do modo capitalista de produção no território brasileiro é contraditório e combinado. Isso quer dizer que, ao mesmo tempo em que esse desenvolvimento avança reproduzindo relações especificamente capitalistas (implantando o trabalho assalariado através da presença no campo do "boia-fria"), o capitalismo produz também, igual e contraditoriamente, relações camponesas de produção (através da presença e do aumento do trabalho familiar no campo) (OLIVEIRA, 2004, p. 35).

Porém, o avanço do modo capitalista de produção sobre o campo produz outras contradições importantes. Os camponeses, apesar de gerarem relações não-capitalistas de produção, não estão isolados - fazem parte da sociedade, participam da acumulação capitalista. Mas sua forma de submissão ao capital não se dá através do seu trabalho, seja real ou formalmente, como no trabalho assalariado: se submetem ao capital através da renda de sua terra, transferida na comercialização dos produtos de seu trabalho (OLIVEIRA, 2007, p. 39). Seu trabalho, portanto, é independente e livre: "O camponês é livre na medida em que é dono de seus instrumentos de trabalho ou, no mínimo, dono de sua vontade quanto ao que produzir, como produzir e para quem vender" (MARTINS, 2008, p. 64).

Esta liberdade também está sujeita, porém, a oscilações, fruto das contradições do avanço do capitalismo no campo. Na região Sul do Brasil ainda é muito comum o trabalho da família camponesa com a fumicultura e, neste caso, apesar de os meios de produção - terra e equipamentos - ser de propriedade da família, seu processo de trabalho está condicionado às regras da empresa que compra

75 "Mesmo que ela [a terra] não seja sua, que ele a alugue de um proprietário, que pague uma renda da terra, ainda assim, durante o período de vigência do aluguel dela, usará como se fosse sua. $\mathrm{Na}$ verdade, ele alugou o meio de produção, como poderia alugar as ferramentas, as máquinas, a casa. Em princípio, é ele que decide o que fazer na terra" (MARTINS, 2008, p. 60). 
seu produto. Todas as famílias entrevistadas em nosso trabalho de campo que trabalhavam em sua propriedade com sistemas de integração - como fumo, suínos ou aves - se arrependiam por ter entrado nesta lógica (principalmente devido ao trabalho pesado e a dívida contraída para a instalação dos equipamentos conforme as exigências da empresa) e estavam se organizando para, assim que quitadas as dívidas, voltarem a produzir itens diversificados para a feira da cidade ${ }^{76}$. Assim, o capitalismo inventa formas mais ou menos incisivas de exploração do campesinato, mas que também oscilam de acordo com a capacidade e o contexto em que se encontra a família, não sendo, portanto, uma via de mão única - e sem volta.

A produção para o autoconsumo também participa desta oscilação. Em termos conceituais, geralmente é compreendida apenas como a produção de alimentos para o suprimento das necessidades alimentares da família camponesa, mas sugerimos aqui ampliar o escopo desta interpretação, conforme apontado por Gazolla (2007, p. 90): a produção para o autoconsumo "compreende todo o tipo de produção, bens, ferramentas de trabalho ou outros produtos que são gerados no interior da unidade familiar e utilizados pelos seus membros para suprir as suas necessidades". Ou seja, trata-se do auto-aprovisionamento de itens básicos essenciais para a família camponesa, tanto para a realização de seu trabalho produtivo quanto para sua reprodução social, sem a mediação do mercado. Em outras palavras, o autoconsumo é uma prática essencialmente nãocapitalista, pois desvincula a mediação do mercado de parte da provisão alimentar, ferramentas, utensílios etc. da família camponesa, já que implica sua produção no interior da unidade camponesa. Diferentemente do operário, que acessa esses bens essenciais através da mediação de um salário obtido através da venda de sua força de trabalho -, no caso do camponês ele mesmo os produz. Sua existência, manutenção e oscilação demonstram, portanto, a condição contraditória em que se encontra o campesinato dentro do capitalismo: da mesma forma que nas relações de trabalho, a produção de autoconsumo por vezes deixa de existir no cotidiano da família camponesa, e retorna quando volta a predominar um contexto de trabalho independente.

Conforme levantado por Coelho e Fabrini (2014, p. 74) a partir do debate sobre o autoconsumo camponês, a literatura clássica sobre o campesinato interpreta que a unidade camponesa é, ao mesmo tempo, uma unidade de consumo e de produção ${ }^{77}$. Esta interpretação pode ser feita tendo em vista o próprio habitat camponês: é na casa e seu entorno que estas duas características se fundem. A casa camponesa, por excelência, apresenta esta dupla função de organizar

76 "Infelizmente anda temo na escravidão da suinocultura [...]. Eles [a empresa integradora] dão os porquinho e a ração, a gente só entra com a mão-de-obra, as instalação... e ainda temo lá peleando. Até que tenha dívida, né... agente pediu um empréstimo, tem momento em que a gente não para pra pensar. Faz 14 anos atrás, a gente não tinha o conhecimento que temos agora, de entender que não é a gente que precisa da empresa, é a empresa que precisa [da gente], né?” (Informante 1 em entrevista a autora em setembro de 2015).

77 Os autores destacam, em particular, as obras "La organización de la unidad económica campesina" de Alexander Chayanov e "Sociedades Camponesas", de Eric Wolf. 
o espaço de reprodução social da família e também de suprir as necessidades funcionais de produção, dentro do que lhe concerne.

A construção da casa camponesa como produto do trabalho familiar, sem a mediação direta das relações capitalistas de produção, é relatada em diversos textos sobre o campesinato. A situação dos colonos recém-chegados no estado a partir de meados do século XIX, como comentado anteriormente, são um exemplo interessante. Conforme relatamos no primeiro capítulo, estes colonos pioneiros enfrentaram muitas dificuldades quando depararam com a densa mata atlântica, ainda intocada, das escarpas catarinenses, tamanho era o despreparo para a nova realidade. Algumas famílias haviam trazido da Alemanha, "com muito custo, louças finas, grossos cobertores de penas de ganso, roupas de lã e feltro demasiado grossas, enfeites para a casa e até móveis pesados" (SEYFERTH, 1999, p. 56), sendo que o que mais precisariam de imediato era um machado, uma enxada e uma foice. Após abrir a picada em meio à mata para conseguir acessar seu lote, construíam sua primeira e rústica moradia com troncos de palmeira e coberta com palha. Geralmente a mão-deobra era do próprio colono, ou com a ajuda dos filhos quando estes já eram adultos. A casa definitiva seria construída apenas depois, quando a família "melhorava de situação" (p. 92), e era feita de madeira ou enxaimel sob regime de mutirão. É interessante destacar que, neste contexto histórico, a construção das casas não se constituía especialidade de trabalho; todos sabiam edificar uma construção para fins habitacionais. Diferente, por exemplo, da construção dos engenhos, que exigiam trabalho especializado, conforme relato:

Embora o colono, em geral, tivesse condições de construir sua casa e os demais ranchos da propriedade, a construção dos engenhos era sempre feita por um especialista - isto é, um carpinteiro (p. 69).

$[\ldots]$

$\mathrm{O}$ trabalho artesanal oscilava entre atividades que não requeriam nenhuma especialização, até atividades muito especializadas [...] A construção e a utilização de engenhos e moinhos era atividade [e especialidade] do artesão [...] O beneficiamento das folhas de fumo, a fabricação de banha e da farinha, a construção de casas e a indústria de laticínios não constituíam especialidade de ninguém (SEYFETH, 1999, p. 120, grifo nosso).

A casa, portanto, apesar de demandar um grande volume de trabalho concentrado para sua execução, constituía-se em mais um dos itens da produção familiar para o autoconsumo, assim como fabricar banha, farinha, queijo e manteiga. Afinal, como vimos anteriormente, "todo agricultor tem um pouco de pedreiro".

Do ponto de vista histórico, poderíamos concluir, portanto, que o processo de produção da habitação camponesa é constituído majoritariamente por relações não-capitalistas de produção, já que esta faz parte da dinâmica familiar como um dos itens básicos do autoconsumo da família - assim como a produção de alimentos "pro gasto". Podemos também indicar, portanto, que o regime de 
construção que predomina e se adequa a esta dinâmica é a autoconstrução, uma vez que isso significa exatamente que a habitação será construída pelas próprias mãos dos futuros moradores, sem mobilização do mercado de mão-de-obra e sem (ou com mínima) mobilização do mercado de materiais de construção.

Sob o PNHR, esta lógica da produção da casa camponesa não se realiza plenamente. Iremos debater este tema no próximo subitem, mas neste momento gostaríamos de acrescentar à discussão sobre a autoconstrução camponesa uma breve reflexão relacionando-a à autoconstrução na periferia das grandes cidades brasileiras.

\section{Esboço: autoconstrução camponesa versus autoconstrução operária}

Nos feriados, fins de semana ou férias, quando ergue sua casa, o trabalhador produz para si. Não como o faz diariamente, como força de trabalho vendida, empenhada na valorização do capital. Não como mercadoria abstrata - força socialmente necessária - a produzir valores genéricos encarnados em valores de uso a ele indiferentes, não enfrentando os meios de produção como poderes materiais hostis e alheios. Ao contrário, produz com seus instrumentos seu abrigo, meios de produção próprios guiados por sua vontade e direção a construir um objeto para seu uso (FERRO, 2006, p. 65)

O significado da autoconstrução nas periferias das grandes cidades brasileiras já foi objeto de estudo de muitos teóricos na arquitetura e no urbanismo. Sérgio Ferro, em 1969 - seguido de Francisco de Oliveira, alguns anos depois -, tece a conhecida crítica segundo a qual a autoprovisão da habitação social urbana - a autoconstrução - é compreendida enquanto superexploração da força de trabalho do operário, cuja consequência é o rebaixamento do seu salário em virtude da redução da pressão para que se inclua, na composição do salário ${ }^{78}$, a cota devida à habitação. Ou seja, o operário que, por falta de alternativas constrói a própria casa na cidade informal, é penalizado através da diminuição de seu salário. Queremos aqui defender a ideia de que o mesmo regime de construção, a autoconstrução, quando observado dentro do contexto do campesinato, não produz as mesmas consequências por estar inserido em outra lógica, conforme apontamos anteriormente.

O trecho reproduzido acima, do texto "A Produção da Casa no Brasil", tem como foco do debate a produção da moradia operária autoconstruída. Esta só pode se dar fora do período de

${ }^{78}$ Cabe aqui observarmos que este argumento já foi contestado de algumas formas. Talvez a mais procedente seja aquela que defende que o trabalhador, ao produzir para si mesmo, não produz mais-valia relativa - que seria liminarmente apropriada pelo comprador da força de trabalho do trabalhador. Assim, não há mediação do salário na obtenção de cota salarial para a produção da sua moradia (ver BARAVELLI, J. E., 2006, particularmente página 88). 
trabalho regular do assalariado já que, durante a venda da sua força de trabalho, o fruto de seu trabalho não lhe pertence, "já nasce como propriedade do capitalista” (MARTINS, 2008, p. 60). E vende sua força de trabalho porque "é o único modo de obter seus meios de vida, aquilo de que necessita para sobreviver, isto é, o dinheiro, o salário, com que poderá comprar os meios de vida” (p. 64). Porém, a casa, sua moradia, também seu meio de vida, lhe foi negada enquanto direito e enquanto condição inerente de sua reprodução social: a moradia não participa enquanto fração do salário, não está incluída na remuneração por sua força de trabalho. Mas, ainda assim, o operário precisa morar, e então autoconstrói.

Como vimos anteriormente, por princípio o camponês produz para si. Não vende sua força de trabalho, pois ainda dispõe dos instrumentos de produção - a terra, as ferramentas, as máquinas. Sua remuneração se realiza sobre a venda do fruto de seu trabalho, que nasce como seu. Para o camponês, o dia de trabalho e o dia de folga se fundem do ponto de vista econômico. A produção e a reprodução social de si e de sua família se dão no mesmo espaço. Indagado sobre o porquê não ia embora para a área urbana, um jovem camponês de 25 anos, durante nosso trabalho de campo, respondeu: "[aqui no campo,] se deu vontade, tá chovendo, não precisa se estressar. E lá [na cidade], chova ou não chova, faça sol... [tem que ir trabalhar]. Claro que na época da colheita do fumo, faça chuva ou faça sol tem que ir, começou tem que fazer. Mas aqui você tem a escolha, você é seu próprio chefe" (Informação verbal ${ }^{79}$ ). A casa camponesa também é autoconstruída nos períodos de folga, como vimos - na entressafra ou em outros períodos livres, como no intervalo entre a lida com os animais, por exemplo -, porém não constitui trabalho diverso do trabalho cotidiano: continua produzindo para si, e o produto de seu trabalho continuará sendo seu, para seu usufruto. A produção para a venda e a produção dos meios de vida para o autoconsumo, apesar de terem destinações distintas dentro da lógica camponesa, nascem ambas como produto acabado e de propriedade do camponês.

Por outro lado, são muitas as semelhanças entre a casa autoconstruída no campo e na cidade, principalmente do ponto de vista técnico. Assim como a casa camponesa que, como vimos, é construída no seio da produção dos meios de vida e não exige especialização alguma para sua realização, um mecanismo similar ocorre com a casa do operário:

A técnica utilizada, mais do que aprendida, é vista, vivida, absorvida por contínua vizinhança. Faz parte do conhecimento popular quase espontâneo, que todos herdam, simples prática compatível com nenhuma especialização. A pesquisa referida mostrou pequena impossibilidade dos operários enfrentarem, eles sozinhos, a construção da própria moradia, apenas $11,5 \%$. Entre os $88,5 \%$ capazes, havia de todas as áreas de produção, têxteis, mecânicos, carpinteiros, serventes, faxineiros (FERRO, 2006, p. 62).

\footnotetext{
${ }^{79}$ Informante 8, em entrevista à autora em setembro de 2015.
} 
Praticamente todos sabem construir suas casas: é um conhecimento que se transmite socialmente. Se não sabem aprendem, pedem ajuda, e na pior situação se transformam em "serventes solícitos" (idem, p. 61), enquanto algum parente ou vizinho mais experiente assume a direção da obra. E, assim como na casa operária, também na casa camponesa o produto a que se chega é uma casa mínima, dotada apenas do indispensável - devendo-se apenas lembrar que o "indispensável” difere entre o meio urbano e o campesinato. Os materiais utilizados são, da mesma forma, os disponíveis nas proximidades, recorrendo a componentes industrializados apenas excepcionalmente.

Apesar das semelhanças, porém, trata-se de processos produtivos diferentes. Principalmente porque a autoconstrução, dentro da realidade camponesa, não se aplica ao que Francisco de Oliveira chama, "audazmente, de acumulação primitiva", onde a habitação "se produz por trabalho não pago", contribuindo para o "aumento da taxa de exploração da força de trabalho, pois o seu resultado - a casa - reflete-se numa baixa aparente do custo de reprodução da força de trabalho - de que os gastos com habitação são um componente importante" (OLIVEIRA, 2003, p. 59). A autoconstrução no campesinato se trata de nada mais que uma parcela da produção dos meios de vida da família camponesa, produção de um dos itens do autoconsumo da família, assim como a produção das hortaliças "pro gasto".

É comum encontrar estudos a respeito do mundo agrário que consideram que o aumento do número de tratores nas pequenas propriedades do país é a comprovação de que o "capitalismo está penetrando no campo". Ou seja, julga-se que a substituição do trabalho manual pelo trabalho mecanizado corresponde à transformação das relações sociais de produção. Mas, se analisarmos de perto, perceberemos que, no caso do campesinato, ainda que o camponês deixe de arar a terra manualmente e passe a utilizar um trator, ele não deixará de ser um camponês. Continuará a trabalhar com sua família, apenas o trabalho será menos árduo; as relações de produção que ele estabelece seguirão sendo relações não-capitalistas de produção (se assim o quiser). Da mesma forma, verificamos durante o trabalho de campo que existe um grau significativo de mecanização no processo produtivo das habitações pelo PNHR. As madeiras são trabalhadas com serras elétricas diversas e não com os velhos (e bons) serrote, arco de pua e formão; a argamassa e o concreto são misturados na betoneira ou, excepcionalmente, até mesmo usinados, ao invés de serem virados na mão por um servente. Mas, segundo nossa compreensão, nada disso indica, por si só, que o processo produtivo da habitação camponesa mudou. No campo da arquitetura e do urbanismo, análises vêm sendo realizadas com o objetivo de compreender os significados, desde o ponto de vista do processo produtivo, da mudança do patamar tecnológico nas obras de conjuntos habitacionais financiados pelo 
programa $\mathrm{MCMV}^{80}$. É um debate em construção e que se relaciona diretamente com o debate sobre o avanço do capitalismo no campo brasileiro.

\subsection{O PNHR/MCMV e a submissão do campesinato ao capital}

Seria prematura qualquer análise muito aprofundada a respeito dos mecanismos de submissão do campesinato ao capital no processo de produção das casas subsidiadas pelo PNHR, tendo por base apenas o pequeno universo observado em campo durante nossa pesquisa. Porém, consideramos interessante desde já explorar alguns aspectos desta questão, dada a relevância e coerência entre o tema da produção habitacional camponesa e o referencial teórico aqui utilizado. Vamos aqui destacar apenas três aspectos, que neste momento se mostram mais relevantes neste sentido.

O primeiro aspecto diz respeito à própria estrutura do programa, cujas regras limitam a ação das famílias envolvidas e acabam por formatar um esquema de submissão difícil de escapar. $\mathrm{O}$ uso do recurso, cujo subsídio é de $96 \%$, está condicionado ao atendimento de uma série de condicionantes, que vão desde o tamanho mínimo de cada ambiente até o sistema construtivo e os materiais de acabamento. A utilização de técnicas construtivas não convencionais e materiais locais não são permitidos. Teoricamente, a planta das casas pode ser diferente para cada novo contrato, mas raramente são elaborados novos projetos arquitetônicos: a CEF possui modelos pré-aprovados, que facilitam e agilizam o processo de seleção e liberação do recurso. Além disso, a pequena verba disponível para pagamento de assessoria técnica em arquitetura e engenharia é liberada apenas após a contratação da obra e, como as Entidades Organizadoras não possuem qualquer capital de giro para contratar este tipo de serviço com antecedência, isso as induz a submeterem-se à seleção do programa com o modelo pronto que tiver disponível ou que já tiver sido submetido à aprovação pelo banco. Quanto ao processo produtivo em si, já vimos que o funcionamento do PNHR não se adequa satisfatoriamente ao regime de autoconstrução, principalmente devido às particularidades da dinâmica do trabalho camponês e, consequentemente, da disponibilidade de tempo livre da família para executar tal tarefa, incompatível com a imprevisibilidade da liberação de recursos do programa. Além dessas questões, é importante relembrar que se trata, afinal, de um programa excludente: está direcionado apenas para um tipo de campesinato, os camponeses proprietários ${ }^{81}$, deixando de fora todas as outras formas de titularidade da terra; utiliza a DAP como critério de enquadramento, o que exclui grande parte das famílias que trabalham em sistemas de integração; disponibiliza valores injustificavelmente menores do que os programas urbanos, relegando os habitantes da área rural a

\footnotetext{
${ }^{80}$ Ver, por exemplo, BARAVELLI, J. E. Trabalho e tecnologia no programa MCMV. Tese de doutorado. São Paulo: FAUUSP, 2014.

81 Sempre lembrando que os assentados da reforma agrária também podem acessar o recurso do PNHR, constituindo hoje ainda parcela mínima da totalidade dos acessos.
} 
uma categoria inferior enquanto cidadãos. Sua característica excludente e seus critérios restritivos apontam a sansão aplicada aos que não se submetem: não poderão acessar o recurso público, seu por direito.

O segundo aspecto a ser considerado diz respeito a trajetória da Fetraf e a sua forma de lidar com estas características genéricas do programa. Após nossa breve reflexão quanto às teorias sobre o campesinato, podemos interpretar que os movimentos de reivindicação do campo se encontram em meio a uma contradição: por um lado, a existência do campesinato é necessária, enquanto classe, para viabilizar a manutenção do modo capitalista de produção, uma vez que gera relações não-capitalistas e dessa forma permite a permanente acumulação primitiva do capital. Os camponeses são, assim, impelidos a seguir existindo e resistindo enquanto tal. Mas suas condições de vida e reprodução são desfavoráveis e constantemente atacadas pelos grupos hegemônicos, e a busca por reverter este quadro os mobiliza e os leva à organização e à luta. Encontram-se, portanto, numa fronteira entre serem indispensáveis e ao mesmo tempo inconvenientes ao capital - situação incômoda por um lado, mas que guarda em si um grande potencial do ponto de vista da luta social.

A trajetória dos movimentos sindicais do campo no Brasil, brevemente trabalhada no primeiro capítulo, procura investigar a forma como estes grupos atuam em meio a esta contradição - e a tantas outras. A atuação da Contag durante a ditadura, contida nos termos da lei e resumida a um "sindicalismo assistencial" - pois era melhor "fazer pouco do que não fazer nada" no contexto de repressão militar -, não foi completamente deixada de lado após a redemocratização. A bandeira da reforma agrária, assumida com competência pelo então recém-fundado MST, foi abandonada pela Contag e pelo DNTR/CUT, e a postura "contida nos termos da lei" um pouco depois se transformou numa postura propositiva, com foco na colaboração ou mesmo "cogestão" das políticas públicas para o campo, como vimos. A adoção da identidade "agricultores familiares" à base representada pelos movimentos sindicais, ocorrida na sequencia, mostrou-se conveniente e adaptada aos critérios de acesso ao pacote de programas sociais do governo para alguns grupos camponeses, como o PRONAF, o PNCF e o próprio PNHR.

Porém, como vimos, estes sindicatos frequentemente representavam apenas um determinado grupo de camponeses, os proprietários - origem da maioria dos agricultores que assumiram cargos de dirigentes ao longo dos anos nestas organizações. Inevitavelmente, o direcionamento dos programas e políticas que ajudaram a elaborar e gerir junto ao governo federal trouxe consigo as características e necessidades deste grupo específico, deixando de fora outras realidades camponesas. Esta situação pode ser constatada a partir de algumas regras do PNHR, por exemplo, quando apenas proprietários da terra têm direito a acessar o recurso habitacional, excluindo os posseiros, arrendatários e outros. 
Como vimos, a questão fundiária, principalmente em relação à reforma agrária, está realmente desconectada da prática do programa.

Esta postura de cogestão das políticas públicas pode ser interpretada como uma releitura do antigo papel que os sindicatos exerciam durante a ditadura militar, muito ligado ao assistencialismo como comentamos anteriormente, o sindicato era visto pelos moradores do campo como "a prefeitura da área rural", constantemente confundido com uma extensão do Estado. A partir do momento em que o sindicato passa a atuar como cogestor dos programas públicos, postura claramente adotada pela Fetraf a partir de sua fundação, conforme Bolter (2014), o que vemos é a reiteração e agravamento desta mesma condição: o sindicato renuncia a qualquer possibilidade de agregar descontentamentos e reivindicações de seus representantes, pois agora é, efetivamente, parte do Estado, conhece suas entranhas e limites e por isso responde por ele - ao invés de enfrenta-lo. Como vimos, a Cooperhaf é objeto privilegiado para esta análise, realizando com a CEF uma verdadeira parceria para viabilização do PNHR. Mais do que representação dos agricultores enquanto Entidade Organizadora, propriamente, realizam "a gestão da operacionalização do Programa" (ROVER; MUNARINI, 2010, p. 266):

A CEF não disponibiliza estrutura pessoal e técnica para chegar até as famílias no meio rural, enquanto as associações, cooperativas e Sintrafs conhecem melhor a realidade das famílias e com facilidade realizam trabalhos de campo como: cadastro de informações sobre a família que está solicitando o recurso, a análise de seu enquadramento às regras do programa, além do encaminhamento da proposta para uma equipe de engenharia para elaborar o projeto técnico (p. 264).

Neste sentido, se analisamos a própria trajetória desta organização sindical da perspectiva da submissão do campesinato ao capital - trajetória esta que culmina na cogestão de programas públicos como o PNHR -, poderemos identificar também um movimento contraditório: por um lado, verificamos o protagonismo do sindicato numa disputa pela repartição dos fundos públicos para fazer cumprir determinados direitos dos camponeses, como os seguros, fomentos e os diversos programas até hoje conquistados. Por outro lado, vemos um enfraquecimento da própria estrutura de representação sindical, causado pelo mimetismo entre suas funções e as do Estado na viabilização destes programas e no fazer cumprir destes direitos. São mecanismos que se, por um lado, auxiliam na emancipação deste campesinato, por outro lado - e ao mesmo tempo - o vinculam ainda mais a um universo de improvável transformação mais profunda da realidade. Se por um lado são eles que produzem a comida para abastecer o mercado interno - e com isso deixam claro que são indispensáveis para a construção da soberania nacional -, por outro lado ausentam a bandeira da reforma agrária de suas reivindicações, ainda que a realização de uma reforma agrária pudesse ampliar seu próprio campo de atuação. 
E dentro deste contexto, podemos interpretar também a atuação da própria Cooperhaf junto ao PNHR. O mecanismo forjado pela cooperativa para viabilizar o acesso ao programa -, que vimos chamando de "arranjo Cooperhaf/Sintraf" -, organiza os agentes envolvidos num formato que funciona de maneira eficiente. A começar pela parceria com os sindicatos locais, que viabiliza uma permeabilidade entre a federação sindical e a família camponesa no acesso a este e outros subsídios e financiamentos públicos. O fato de o coordenador do sindicato conhecer a realidade das famílias permite que o arranjo de acesso ao programa seja a ela coerente e vá se adaptando conforme a necessidade. Da mesma forma, a relação de confiança estabelecida individualmente entre a Cooperhaf e cada loja de materiais de construção é essencial para o funcionamento deste arranjo. Quanto ao regime de autoconstrução, a cooperativa incentiva e tira partido de diferentes formas. Destacam diversas vezes aos camponeses ao longo do processo que a autoconstrução é o único regime construtivo que permitirá à família ter sua casa concretizada quase que exclusivamente com os recursos do programa, sem a necessidade de fornecer contrapartidas financeiras - devido, obviamente, ao rebaixamento dos valores disponibilizados. Assim, durante as reuniões do TS, buscam instruir os futuros moradores a construir a própria casa e se disponibilizam a assessorá-los através de seus coordenadores municipais de habitação ${ }^{82}$. Complementarmente, disponibilizam à escolha das famílias diferentes projetos arquitetônicos pré-aprovados, de forma a adequá-los à sua capacidade de contrapartida, seja monetária ou em mão-de-obra na construção de sua casa.

Portanto, da mesma forma, é importante analisar as contribuições da cooperativa ao fenômeno de submissão do campesinato ao capital a partir das contradições nas quais está inserida. O incentivo à autoconstrução carrega em si uma grande contradição na medida em que, por um lado, é adequado ao modo de vida camponês - conforme defendemos anteriormente, é o regime de construção que se mostra mais coerente com o processo de produção da casa camponesa enquanto produto do autoconsumo da família - contribuindo assim positivamente na sua emancipação enquanto tal. Porém, por outro lado, acaba se tornando a única alternativa para muitas famílias apenas devido à precariedade do programa em relação ao insuficiente valor para se remunerar corretamente a construção de uma casa. Se defendemos anteriormente que a autoconstrução não configura superexploração da mão-de-obra do camponês, assim como ocorre com o trabalhador assalariado na periferia das grandes cidades, isso não significa que este regime de construção não configure outros tipos de exploração na realidade camponesa. A diferença de valor em relação a versão não urbana do programa MCMV acaba, dentro do arranjo Cooperhaf/Sintraf, sendo absorvido pelo trabalho das próprias famílias na construção de sua casa.

\footnotetext{
82 Apesar destes nem sempre terem experiência prévia com construção civil.
} 
De maneira geral, compreendemos que a produção da moradia camponesa no contexto estudado provoca uma oscilação entre maiores e menores graus de submissão do campesinato ao capital, na medida em que a produção da casa adquire maiores ou menores características de mercadoria. 


\section{Considerações finais}

Não utilizamos intencionalmente a expressão "habitação rural" em nossa pesquisa, quando nos referimos ao nosso objeto de estudo. Em primeiro lugar, por uma razão muito evidente: não estamos neste trabalho falando de qualquer habitação nas áreas rurais do país - universo que englobaria também a casa de fazenda de um latifundiário, por exemplo. Estamos falando, no mínimo, daquelas construídas por e para a moradia da população pobre do campo, dos que abocanham a menor parcela na remuneração pelo trabalho no meio rural, dos expropriados; compreendendo que por "expropriados" não nos referimos apenas à privação de sua terra de trabalho, mas também de seus direitos, de seu modo de vida, e que luta contra esta expropriação no interior dos movimentos organizados. É a população que, devido a faixa média de renda, acessa os programas sociais do governo federal. Estamos falando da população que, através da divisão familiar do trabalho, produz pelo menos $70 \%$ do alimento que chega à nossa mesa.

Em segundo lugar, optamos pela expressão "habitação camponesa" porque o "campesinato" é um termo em disputa; traz consigo um significado político que tem por base a compreensão de que os camponeses - e consigo as relações não-capitalistas de produção - seguirão existindo apesar do avanço do capitalismo no campo, conforme defendemos anteriormente. Esta concepção diverge das ideias apresentadas pela teoria da modernização, segundo a qual o campo está a caminho da purificação das relações sociais de produção, levando consequentemente ao aumento progressivo da submissão do trabalho camponês ao capital e à sua inerente proletarização - deixando os camponeses de existirem enquanto tal ${ }^{83}$. Diverge também da tese segundo a qual os camponeses deixariam de existir enquanto tal devido a necessidade de sua própria manutenção no mercado competitivo; só haveria espaço para a reprodução das relações familiares no campo através do reforço de uma "natureza fundamentalmente empresarial", com "capacidade de inovação técnica e de resposta aos apelos de mercado" (ABRAMOVAY, 1992, p. 19), o que não poderia ser realizado pela unidade camponesa como conhecemos hoje. Esta segunda compreensão é a que dá origem e fundamenta a utilização da expressão "agricultor familiar" em substituição ao campesinato, e que se generalizou nas políticas públicas e movimentos sindicais na década de 1990, como vimos ao longo do trabalho ${ }^{84}$.

Por último, não utilizamos a expressão "habitação rural" em nosso texto para marcar uma posição acerca do debate sobre espaço rural e espaço urbano, e esclarecer a relevância desta discussão do ponto de vista de nosso objeto de pesquisa. Alguns estudos ${ }^{85}$ questionam os critérios utilizados

${ }^{83}$ Conforme defendido por José Graziano da Silva (1998).

${ }^{84}$ Ricardo Abramovay escreve sua tese de doutorado sobre o tema e fundamenta sua formulação com base em Max Weber, abandonando o marxismo e o debate sobre classes sociais por considerar que o mesmo não consegue explicar as mudanças no campo brasileiro. Como vimos, a expressão "agricultura familiar" é absorvida pelo Estado e ganha conotação institucionalizada.

85 (VALADARES, 2014) e (VEIGA, 2001) 
para a definição das áreas rurais e urbanas, assim como a definição de "cidade" - uma noção vigente e imutável desde a instituição do Decreto n. 311 de 1938:

Instituído sob o Estado Novo, período em que se gestou um projeto de modernização fundado no binômio industrialização-urbanização, este decreto conferiu a condição de 'cidade' a todas as sedes municipais. Tal critério converteu automaticamente em área urbana qualquer localidade que tivesse esta designação administrativa, independentemente de suas características espaciais e demográficas (VALADARES, 2014, p.7).

Assim, hoje temos no país 5.570 municípios, sendo que $3.914^{86}$, ou seja, $70 \%$ possuem até 20 mil habitantes - os quais, segundo o Estatuto da Cidade, estão isentos de elaboração de plano diretor, “consagrando este patamar como dimensão populacional mínima compatível com um município de características urbanas" (VALADARES, 2014, p. 11). Junto a este dado, é importante lembrar que a determinação de perímetro urbano no Brasil atualmente é um ato puramente administrativo, sendo determinada por projetos de lei que são submetidos à aprovação na câmara de vereadores de cada município. O perímetro urbano é, por excelência, o local da aplicação - virtual - dos recursos arrecadados através do IPTU, e a área rural é a que sobra: fica determinada pelo negativo da área urbana, e seu destino é servir de estoque para uma futura urbanização. Desta forma, a contagem populacional feita pelo IBGE, que distingue o número de habitantes das áreas rurais e das áreas urbanas dos municípios, passa a ser naturalmente imprecisa, uma vez que este próprio recenseamento utiliza o mesmo critério. Esta polêmica é levantada por José Eli da Veiga (2002) que, em um exercício de estatística, se empenha por demonstrar que "o Brasil é mais rural do que se calcula".

Outros autores também se dedicam a compreender a relação entre campo e cidade, procurando verificar se há um distanciamento, uma aproximação ou mesmo uma sobreposição entre ambos. Porém, apesar de interessante, trata-se de um debate que não concerne à nossa pesquisa. O exercício realizado por Veiga, por exemplo, desconsidera as relações sociais que se dão nestes espaços, uma vez que sua atenção está voltada para a estatística. Em resposta a esse autor, Ana Fani Carlos aponta que “é ingênuo acreditar que as políticas públicas produzidas pelo Estado se orientam pelos dados elaborados pelo IBGE, pois a racionalidade do Estado é outra" e, portanto, "é ingênuo acreditar que mexendo nas estatísticas, redirecionam-se as políticas que vão criar as possibilidades de crescimento" (CARLOS, 2003, p. 182).

Acreditamos que o "rural exprime sobretudo localização" (CANDIDO, 2010, p. 25), e por isso é mais adequado nos referirmos ao nosso objeto de estudo como "habitação camponesa". Entendemos que a relação campo-cidade configura uma unidade dialética, onde os diferentes setores

86 (IBGE, 2010) 
presentes no campo e na cidade vão sendo amalgamados, unidos pelos sujeitos sociais que se deslocam, habitam e trabalham nestes espaços.

A cidade, hoje, revela estas contradições. Ela é, pois, palco e lugar destas lutas rurais/urbanas e/ou urbanas/rurais. O que significa dizer que a compreensão dos processos que atuam na construção/expansão de grande parte das cidades passa pela igualmente necessária compreensão dos processos que atuam no campo [...]. Dessa forma, cidade e campo vão se unindo dialeticamente, quer no processo produtivo, quer no processo de luta por melhores salários, por melhores preços para os produtos agrícolas, e particularmente pela reforma agrária. (OLIVEIRA, 2004, p. 64).

A Guerra do Contestado no meio-oeste e a colonização das escarpas da serra do mar catarinense por imigrantes europeus pioneiros ilustram diferentes origens do campesinato no estado. As diferenças entre caboclos e colonos verificadas historicamente, principalmente quanto a forma de lidar com a titularidade da terra, não representaram para a atualidade grandes diferenças do ponto de vista do lugar que ocupam hoje na sociedade. Apesar das diferenças, hoje ambos produzem alimentos com base no trabalho da família e formam o campesinato.

A diferença que merece destaque é a que ocorre entre o trabalho assalariado e o trabalho camponês, do ponto de vista da forma de submissão ao capital: enquanto o assalariado se relaciona com mundo através de seu trabalho, o camponês se relaciona através de seu produto e sem vender a sua força de trabalho em si. Será a partir desta distinção que poderemos compreender as diferenças entre as lutas sindicais no meio urbano e no meio rural do país, principalmente a partir da década de 1990. E, dentro do sindicalismo rural, uma contradição fundamental deve ser levada em conta: a distância das ações do Estado em relação às necessidades cotidianas da população rural ajudou a forjar uma prática sindical de assistência às necessidades básicas dos camponeses que, ao longo do tempo, se constituiu como principal ação dos sindicatos: em detrimento de uma postura mais combativa e reivindicatória, as organizações sindicais acabam inoculando germes de desmobilização política e conformação. É em meio a esta contradição que nasce a Cooperhaf, braço técnico da Fetraf que viabiliza a chegada dos programas de habitação rural do governo à população.

Algumas iniciativas municipais pontuais ensaiaram outras relações entre Estado e população. Lages na década de 1970 mostrou a efetividade de um trabalho que partia das necessidades dos habitantes e procurava encaminhá-las com base nas decisões tomadas pelas organizações de bairro e núcleos agrícolas - evitando soluções que beneficiavam interesses privados e alimentavam o mercado e a indústria, e valorizando o uso da criatividade da população, haja vista escassez de recursos. Foi 
característica deste processo uma relativa desmercantilização de itens básicos de direito como a habitação, a produção agrícola e a educação.

Mas o que estava por vir por parte do governo federal não seguiu esta lógica. Após menos de uma década de programas habitacionais rurais mitigatórios em âmbito nacional, é lançado em 2009 o programa MCMV e junto com ele uma versão atualizada do PNHR, que aportou subsídios jamais vistos para a área da habitação rural no país. Recortando a compreensão do habitar rural como constituído apenas pela edificação "casa", o PNHR/MCMV, ainda hoje vigente, subsidiou até dezembro de 2016 a construção de mais de 150.000 unidades habitacionais no país. Massivo, portanto, do ponto de vista histórico, o PNHR apartou-se dos debates relativos à reforma agrária, desconsiderou em sua operacionalização mecanismos básicos de reprodução das famílias camponesas e rebaixou injustificavelmente o valor limite dos subsídios em relação àqueles praticados pelo programa na modalidade correlata urbana.

A ação da Cooperhaf enquanto representante de famílias camponesas perante este programa se encontra em meio a um contexto contraditório. Se por um lado busca sanar a necessidade de seus associados por habitação através da viabilização de um programa federal, por outro reproduz uma ação assistencial quando emula a "prefeitura da área rural" - sendo que, inclusive, colabora na elaboração e gestão do referido programa. Ao mesmo tempo, adota procedimentos no processo produtivo das habitações como a autoconstrução que, se por um lado acaba sendo a única solução para a finalização das casas, por outro lado aceita sem grandes questionamentos o rebaixamento de até $74 \%$ em comparação ao valor destinado para o programa MCMV nas cidades.

Com base neste debate, procuramos defender que a produção da casa camponesa deve ser interpretada teoricamente enquanto produção dos meios de vida da família, ou seja, como parte da sua produção do autoconsumo. O trabalho de construção da casa não se constituiu historicamente no campesinato como um trabalho especializado, mas sim um trabalho vulgar, transmitido e conhecido por todos, assim como a produção da manteiga ou da farinha para o consumo próprio da família. E, partindo da compreensão de que o trabalho camponês em princípio não se submete ao capital, a construção da casa camponesa pela própria família não pode ser interpretada conceitualmente como superexploração da força de trabalho, conforme o fazem os trabalhos sobre a autoconstrução nas periferias das grandes cidades. Além disso, se o trabalho camponês não se submete ao capital na produção dos alimentos para a comercialização, no processo produtivo da casa também não deveria se submeter.

Mas interpretamos que o PNHR/MCMV sustenta um mecanismo inverso. Dentro da complexidade existente no processo produtivo da casa camponesa sob o PNHR/MCMV, da qual participam diferentes agentes com diferentes interesses, a submissão do campesinato ao capital oscila. 
Assim como oscila o trabalho camponês quando da submissão aos sistemas de integração com empresas, também oscila a produção da casa, sendo por vezes a submissão maior, quando a mão-de-obra é contratada e os materiais de construção são todos industrializados - conforme as regras do programa -, ou sendo por vezes menor quando a autoconstrução se adequa ao calendário agrícola da família e são utilizados materiais locais, procedimentos incentivados pela Cooperhaf.

Em última instância, os sindicatos e, de forma geral, os movimentos organizados de luta por moradia no campo, são atravessados por uma contradição essencial: o acesso aos recursos do programa os vincula inevitavelmente aos mecanismos de submissão ao capital -, mas abster-se do acesso a tais recursos os relega à precariedade e à privação de direitos. 


\section{BIBLIOGRAFIA}

ABRAMOVAY, Ricardo. O futuro das regiões rurais. Porto Alegre: Editora da UFRGS, 2003.

—. Paradigmas do Capitalismo Agrário em Questão. Unicamp: Editora Hucitec, 1992.

ALMEIDA, Arildo. A participação de assessoria técnica-política e da CAIXA na produção de moradias em assentamentos rurais (Dissertação). São Carlos: UFSCar, 2007.

ALVES, Márcio Moreira. A força do povo: democracia participativa em Lages. São Paulo: Brasiliense, 1988.

ARANTES, Pedro Fiori. Arquitetura na era digital-financeira: desenho, canteiro e renda da forma. São Paulo: Editora 34, 2012.

ARANTES, Pedro, e Mariana FIX. "Como o governo Lula pretende resolver o problema da habitação." Correio da Cidadania, 2009.

ARRUDA, Andrea Figueiredo. O espaço "concebido" e o espaço "vivido" da morada rural:políticas públicas x modo de vida camponês. São Paulo: Dissertação (Mestrado em Arquitetura e Urbanismo), 2007.

ASSOCIAÇÃO BRASILEIRA DE NORMAS TÉCNICAS. NBR 10520 Informação e documentação - Citações em documentos - Apresentação. Rio de Janeiro, 2002.

AURAS, Marli. Guerra do Contestado: a organiz̧ação da irmandade cabocla. Florianópolis: EdUFSC, 2015.

BARAVELLI, José Eduardo. O cooperativismo uruguaio na habitação social de São Paulo (DISSERTAÇÃO). FAU/USP, 2006.

—. Trabalho e Tecnologia no Programa MCMV (Tese). São Paulo, SP: USP, 2014.

BARRETO, Mauricio. Por que duas casas ficam em pé e uma cai? Estudo multicaso do processo construtivo de 3 habitações sociais em adobe nos Assentamentos Rurais Pirituba II e Sepé Tiaraju - SP - Brasil. São Carlos: IAU/USP, 2011.

BLOEMER, Neusa M. “'Colonos italianos' e 'caboclos' no planalto catarinense.” In: Diversidade do campesinato: por Emilia P. GODOI, Marilda A. MENEZES e Rosa A. MARIN. São Paulo: Editora UNESP, 2009.

BOLTER, Jairo. Interfaces e cogestão nas políticas para a agricultura familiar: uma análise do Programa Nacional de Habitação Rural (TESE). Porto Alegre: PGDR/UFRGS, 2013.

BRASIL. Decreto n. 6.819 de 13 de abril de 2009. s.d.

-. Lei n. 11.326 de 24 de julho de 2006. s.d.

—. Portaria Interministerial no 326, de 31 de agosto de 2009. s.d.

_. Portaria Interministerial n 97, de 30/03/2016. Dispõe sobre o Programa Nacional de Habitação Rural - PNHR, integrante do PMCMV, para os fins que especifica. 2016.

CALLADO, Antônio. “A volta às cooperativas da morte.” In: Brasil: Tempos Modernos, por Celso FURTADO. Paz e Terra, 1968. 
CAMPOS, Nazareno José de; BRANDT, Marlon; CANCELIER, Janete Webler;. O espaço rural em Santa Catarina: novos estudos. Florianópolis: Editora da UFSC, 2013.

CÂNDIDO, Antônio. Os Parceiros do Rio Bonito. Rio de Janeiro: Ouro sobre Azul, 2010.

CARDOSO, Adauto Lúcio. O Programa Minha Casa Minha Vida e seus Efeitos Territoriais. Rio de Janeiro: Letra Capital, 2013.

CARLOS, Ana Fani Alessandri. "Seria o Brasil 'menos urbano do que se calcula?'." Revista Geousp 13, 2003.

CARLOTO, Andrea Fão. "Políticas sociais no meio rural: a conquista do Programa Nacional de Habitação Rural." 6o Seminário Nacional Estado e Políticas Sociais. Campos de Toledo, PR: Unioeste, 2014.

CAVALCANTI, Flávio. "Estrada de Ferro São Paulo - Rio Grande: cronologia da ferrovia." Centro-Oeste, set de 1986.

CEF. Caixa Econômica Federal. Produção do PNHR no Brasil - planilha. Brasília: CEF, 2016.

CERQUEIRA, Maria Cândida Teixeira. A assistência técnica nos habitats do MST e o papel do arquiteto e urbanista (Dissertação). Natal: UFRN, 2009.

CIDADES, MINISTÉRIO DAS. Instrução Normativa n. 39 de 19 de dezembro de 2014. s.d.

COELHO, Douglas, e João Edimilson FABRINI. "Produção de subsistência e autoconsumo no contexto de expansão do agronegócio.” NERA - Presidente Prudente - Jul-dez/2014, 2014: 71-87.

COOPERHAF. Projeto Caprichando a Morada, Caderno 1: "Orientações para a construção habitacional". Chapecó, 2008.

- Projeto Caprichando a Morada, Caderno 2: "Organização, cooperativismo e associativismo na agricultura familiar". Chapecó, 2008.

—. Projeto Caprichando a Morada, Caderno 3: "Construindo um ambiente saudável e sustentável". Chapecó, 2008.

—. Projeto Caprichando a Morada, Caderno 4: "Gestão finenceira e social da propriedade". Chapecó, 2008.

ESPIG, Márcia. “A construção da Linha Sul da Estrada de Ferro São Paulo - Rio Grande (1908-1910): mão de obra e migrações." VARLA HISTÓRIA, jul/dez de 2012: 849-869.

FARAH, Marta Ferreira Santos. Processo de trabalho na construção habitacional - tradição e mudança. São Paulo: Editora Annablume, 1996.

FAVARETO, Arilson. "Agricultores, Trabalhadores: os trinta anos do novo sindicalismo rural no Brasil." RBCS Vol. 21, n. 62 (outubro 2006).

FERREIRA, Ana Luiza S. Souto. Lages: um jeito de governar. São Paulo: Pólis Publicações, vol. 5, 1991.

FERREIRA, João Sette Whitaker. Produzir casas ou construir cidades? Desafios para um novo Brasil urbano. São Paulo: FUPAM, 2012.

FERRO, Sérgio. “A Produção da Casa no Brasil.” In: Arquitetura e Trabalho Livre, por Sérgio FERRO, 61-101. São Paulo: Cosac Naify, 2006. 
FJP. Fundação João Pinheiro. Déficit Habitacional Municipal no Brasil 2010. Belo Horizonte: FJP, 2010.

GAZOLLA, Marcio. "A produção da autonomia: os "papéis" do autoconsumo na reprodução social dos agricultores familiares.” Estudos Sociedade e Agricultura, 2007: 89-122.

HENTZ, Carla, Adriano Rodrigues OLIVEIRA, e Wagner BATELLA. "Modernização agrícola, integração agroindustrial e políticas públicas de desenvolvimento rural no Oeste de Santa Catarina." Caderno Prudentino de Geografia, jan/jul de 2013: 41-59.

IBGE. Instituto Brasileiro de Geografia e Estatística. Censo Agropecuário 2006. Rio de Janeiro: IBGE, 2006.

—. Instituto Brasileiro de Geografia e Estatística. Censo Demográfico 2010. Rio de Janeiro: Editora, 2010.

LEITE, Thaisa Marques. Análise da viabilidade técnica e econômica da producão de janelas de madeira de encalipto em uma marcenaria coletiva autogestionária para projetos de habitação social rural (Dissertação). São Carlos: EESC/USP, 2009.

LOPES, João Marcos, e Amadja BORGES. O habitat do campo e a política de habitação de interesse social. Proposta de sessão livre no XV Encontro da ANPUR, 2013.

LUXEMBURGO, Rosa. Reforma ou Revolução. documento eletrônico, 2002.

MAIA, Rafael Torres. Avaliação das variáveis que influenciaram no uso da terra como material construtivo para habitação social rural no Assentamento Rural Sepé Tiaraju - Serra Azul - SP (Dissertação). São Carlos: IAU/USP, 2011.

MARCOS, Valéria de, e João Edimilson FABRINI. Os camponeses e a práxis da producão coletiva. São Paulo: Expressão Popular, 2010.

MARICATO, Ermínia. O impasse da politica urbana no Brasil. Petrópolis, RJ: Editora Vozes Ltda., 2011.

MARTINS, José de Souza. A sociedade vista do abismo: novos estudos sobre exclusão, pobreza e classes sociais. Petrópolis: Editora Vozes, 2008.

—. Caminhada no chão da noite: emancipação política e libertação nos movimentos sociais do campo. São Paulo: Editora HUCITEC, 1989.

—. O Poder do Atraso: ensaios de Sociologia da História Lenta. São Paulo: Editora Hucitec, 1994.

-. Os camponeses e a politica no Brasil: as lutas sociais no campo e seu lugar no processo politico. Petrópolis: Editora Vozes, 1981.

MARTINS, Viviane Santi. Lugar da morada: a constituição do lugar de viver de famílias rurais no contexto de assentamentos da Reforma Agrária (Dissertação). Porto Alegre: UFRGS, 2009.

MARX, Karl. A Ideologia Alemã. São Paulo: Editora Boitempo, 2007.

—. O Capital. São Paulo: Editora Nova Cultural, 1996.

MEDEIROS, Cecília Marilaine. Mutirão x Organicidade: reflexões sobre os processos de construcão coletiva dos habitats dos assentamentos rurais coordenados pelo MST no RN (Dissertação). Natal: UFRN, 2013.

MEDEIROS, Leonilde Sérvolo de. História dos movimentos sociais no campo. Rio de Janeiro: FASE, 1989. 
MINAYO, Maria Cecília de Souza. Pesquisa social: teoria, método e criatividade. Petrópolis: Editora Vozes, 1993.

MUNARINI, Paulo Roberto. A politica de habitacao rural brasileira e o desenvolvimento da agricultura familias no oeste catarinense (Monografia). Chapecó: UNOCHAPECÓ, 2009.

OLIVEIRA, Ariovaldo Umbelino de. "Geografia Agrária: perspectivas no início do Século XXI.” In: O Campo no Século XXI, por Ariovaldo Umbelino de OLIVEIRA, 29-70. São Paulo, SP: Paz e Terra/Casa Amarela, 2004.

_. “Os limites do novo censo agropecuário.” Correio da Cidadania. São Paulo, SP, 10 de 02 de 2010.

_. Modo de Produção Capitalista, Agricultura e Reforma Agrária. São Paulo: FFLCH, 2007.

OLIVEIRA, Francisco de. Crítica à razão sualista - O ornitorinco. São Paulo: Editora Boitempo, 2003.

PEIXOTO, Dermeval. Campanha do Contestado: episódios e impressões. Rio de Janeiro: Segundo Milheiro, 1920.

PERES, Renata Bovo. Discussão e diretrizes para políticas públicas, planejamentos e programas habitacionais (Dissertação). São Carlos: IAU/USP, 2003.

PINHEIRO, Ana Paula. Modo de olhar: metodologia para o estudo de moradias rurais (Dissertação). Fortaleza: UFCE, 2011.

RENK, Arlene. "Expropriação do campesinato caboclo no Oeste catarinense." In: Diversidade do campesinato: expressões e categorias, por Emilia P. GODOI, Marilda A. MENEZES e Rosa A. MARIN. São Paulo: Editora UNESP, 2009.

RODRIGUES, Evaniza Lopes. A Estratégia Fundiária dos movimentos populares na produção autogestionária da moradia. São Paulo: FAU/USP, 2013.

RODRIGUEZ, Angel Castañeda. Qualidade da habitação nos assentamentos rurais no PNHR/PMCMV do estado de São Paulo (Dissertação). São Carlos: IAU/USP, 2016.

ROVER, Oscar José, e Paulo Roberto MUNARINI. “A política de habitação rural e o desenvolvimento da agricultura familiar.” Revista Katálise, jul/dez de 2010: 260-269.

SADER, Eder. Quando novos personagens entram em cena. São Paulo: Paz e Terra, 1988.

SANTO AMORE, Caio; SHIMBO, Lúcia Zanin; RUFINO, Maria Beatriz Cruz;. Minha casa... e a cidade?: avaliação do programa Minha Casa Minha Vida em seis estados brasileiros. Rio de Janeiro: Letra Capital, 2015.

SANTOS, Boaventura de Souza. Produzir para viver: os caminhos da produção não capitalista. Porto: Afrontamento, 2004.

SANTOS, Suellen Nascimento. Realidade, significado e expectativas do Programa Nacional de Habitação Rural: o caso de Guiricema e São Miguel do Anta - MG (Dissertação). Viçosa: UFV, 2014.

SEYFERTH, Giralda. A colonização alemã no vale do Itajaí-mirim. Porto Alegre: Editora Movimento, 1999. 
_. "Colonização européia, campesinato e diferenciação cultural no Vale do Itajaí (SC)." In: Diversidade do campesinato: expressões e categorias, por Emilia P. GODOI, Marilda A. MENEZES e Rosa A. MARIN. São Paulo: Editora UNESP, 2009.

SHIMBO, Lúcia. A Casa é o Pivô (Dissertação). São Carlos: USP, 2004.

—. Habitação Social, Habitação de Mercado: a confluência entre Estado, empresas construtoras e capital financeiro. São Carlos: IAU/USP, 2010.

SILVA, Cecília Milanez Graziano da. Habitação Rural: uma luta por cidadania. São Paulo: FAU-USP, 2014.

SILVA, Iby Montenegro. A Contag em perspectiva: um estudo sobre a formação política. Rio de Janeiro: Dissertação (mestrado em ciências), UFRRJ, 2013.

SILVA, José Graziano da. A nova dinâmica da agricultura brasileira. Campinas: UNICAMP, 1998.

SIMÃO, Azis. Sindicato e Estado. São Paulo: Dominus Editora S.A., 1966.

SINGER, Paul. "A recente ressureição da economia solidária no Brasil." In: Produશir para Viver: os caminhos da produção não capitalista, por Boaventura de Souza SANTOS. Porto: Edições Afrontamento, 2003.

—. Desenvolvimento Econômico e evolução urbana. São Paulo: Companhia Editorial Nacional, 1968.

SORDI, Diogo. Habitação rural: o sentido da nova moradia para os agricultores familiares do Oeste Catarinense (monografia). Chapecó: UNOCHAPECÓ, 2006.

TAVARES, Simone. Análise da organização coletiva no processo de construção da habitação social rural (Dissertação). São Carlos: IAU/USP, 2011.

VALADARES, Alexandre Arbex. O gigante invisivel: território e população rural para além das convenções oficiais. Brasília: IPEA, 2014.

VEIGA, José Eli da. Cidades imaginárias: o Brasil é menos urbano do que se calcula. Campinas, SP: Autores Associados, 2001.

WOLF, Eric. Los campesinos. Barcelona: editorial Labor S.A., 1971. 


\section{ANEXOS}

ANEXO A - Quadro de informantes do trabalho de campo

\begin{tabular}{cl}
\hline Informante & \multicolumn{1}{c}{ Atuação } \\
\hline 1 & Coordenador de habitação do Sintraf \\
\hline 2 & Proprietário de loja de materiais de construção \\
\hline 3 & Proprietário de loja de materiais de construção \\
\hline 4 & Coordenador de habitação do Sintraf \\
\hline 5 & Coordenador de habitação do Sintraf \\
\hline 6 & Coordenador de habitação do Sintraf \\
\hline 7 & Funcionários da Gihab (Gerência Executiva de Habitação) da CEF \\
\hline 8 & Camponês beneficiário do PNHR \\
\hline
\end{tabular}


ANEXO B - Plantas dos diferentes modelos de habitação disponibilizados pela Cooperhaf para escolha das famílias

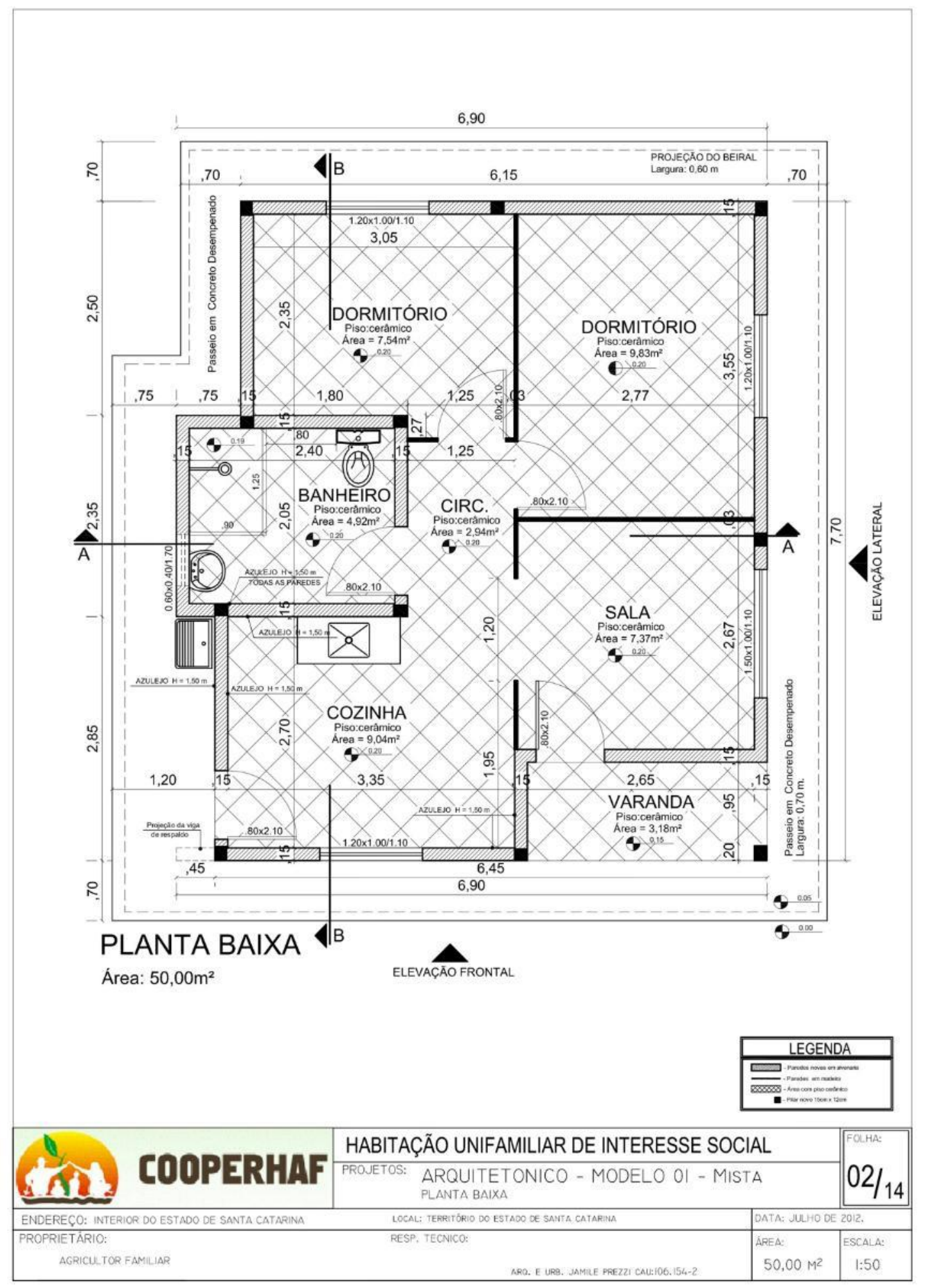


Figura 12: Planta da habitação "Modelo 2"

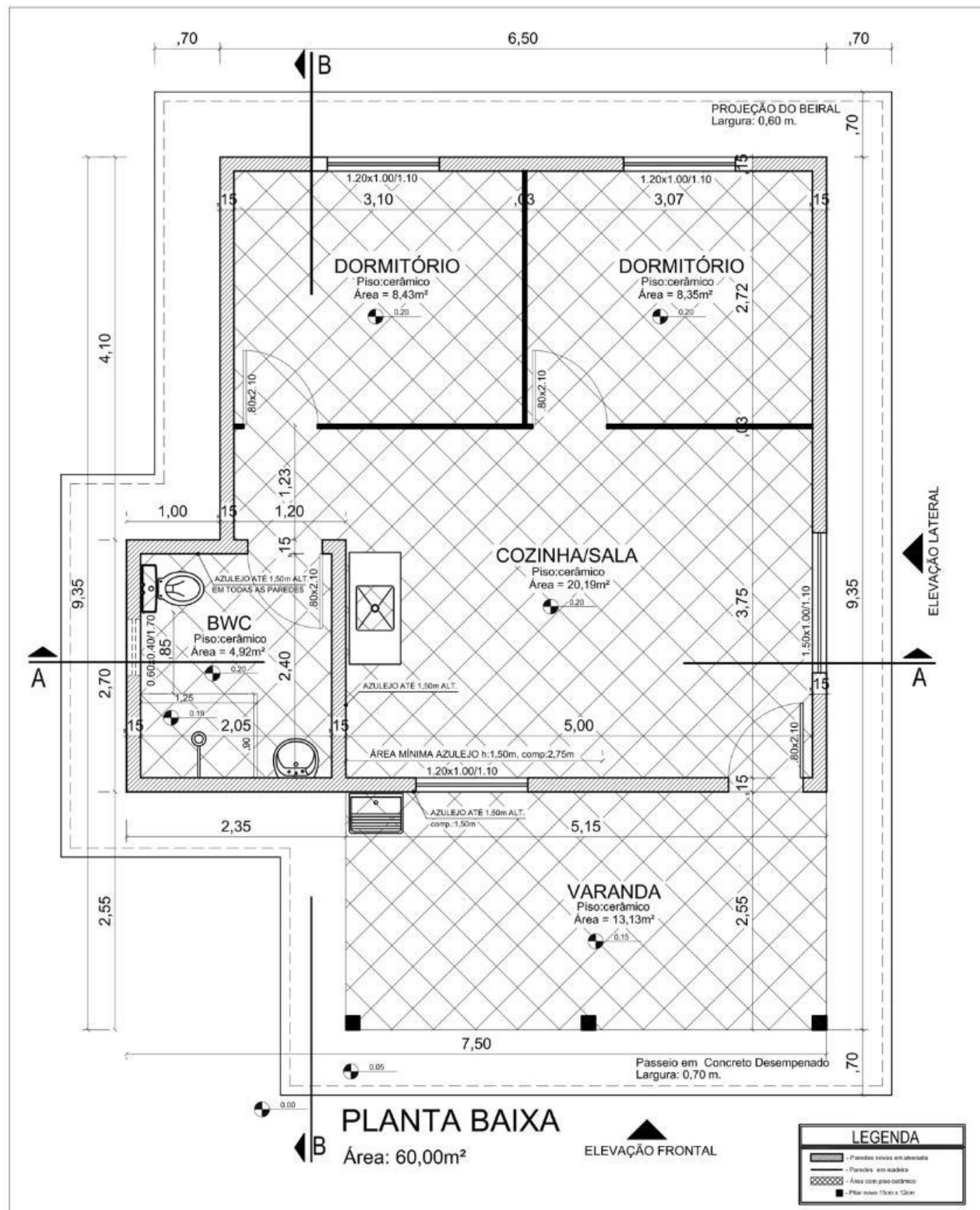

\begin{tabular}{|c|c|c|c|c|}
\hline & \multicolumn{3}{|c|}{ HABITAÇÃO UNIFAMILIAR DE INTERESSE SOCIAL } & \multirow{2}{*}{$02 / 14$} \\
\hline-2 & PROJETOS: & $\begin{array}{l}\text { ARQUITETONICO - MODELO } 02 \text { - MIST, } \\
\text { PLANTA BAIXA }\end{array}$ & & \\
\hline ENDEREÇO: INTERIOR DO ESTADO DE SANTA CATARINA & LOCAL: & 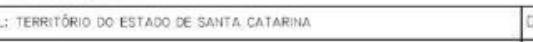 & DATA: JULHOO O & 2012. \\
\hline PROPRIETARIO: & RESP. & TECNICO: & AREA: & ESCALA: \\
\hline AGRICULTOR FAMILAR & & ARQ. E URB. JAMLE PAEZ & $60,00 \mathrm{M}^{2}$ & 1:50 \\
\hline
\end{tabular}


Figura 13: Planta da habitação "Modelo 3"

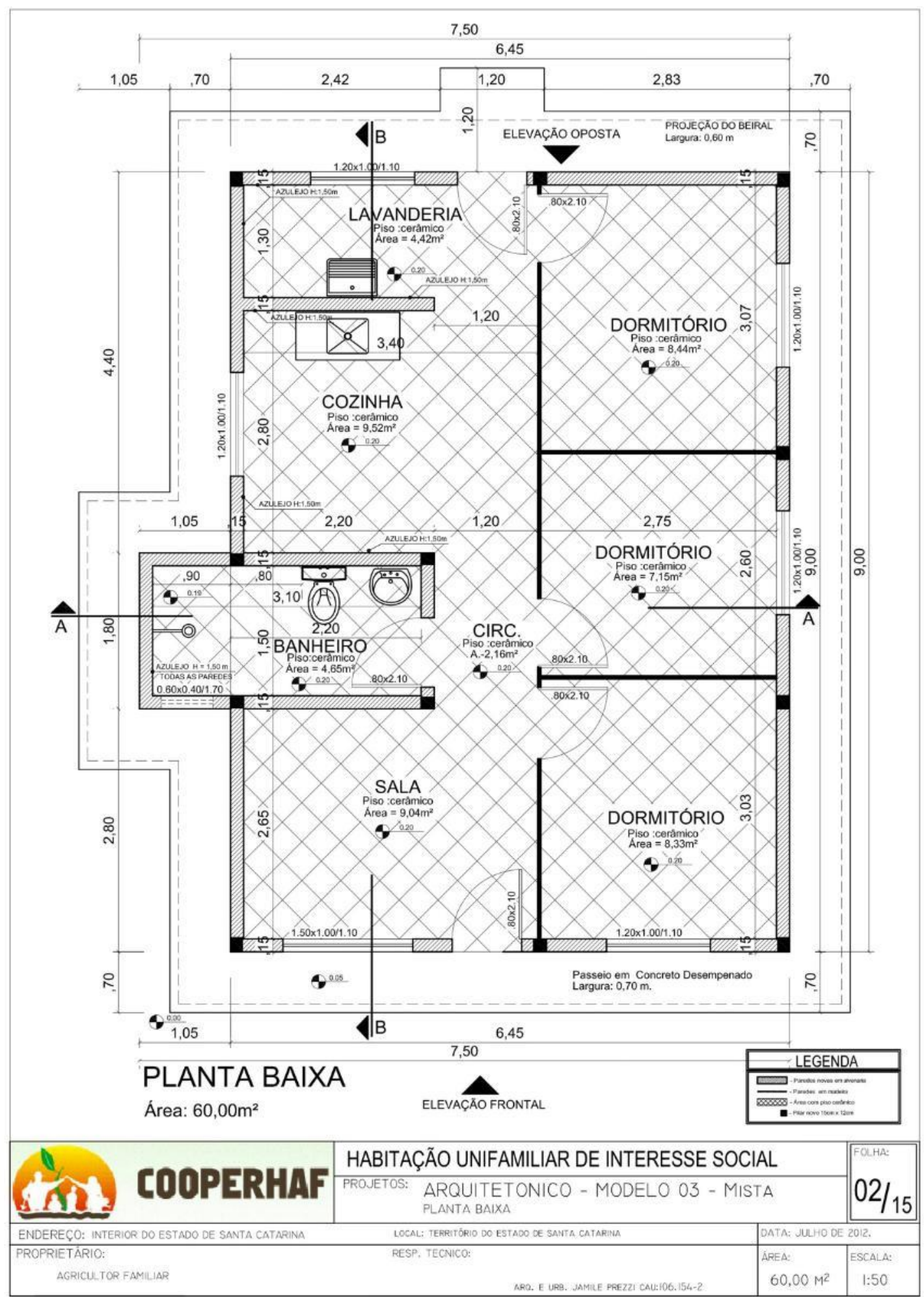


Figura 14: Planta da habitação "Modelo 4"

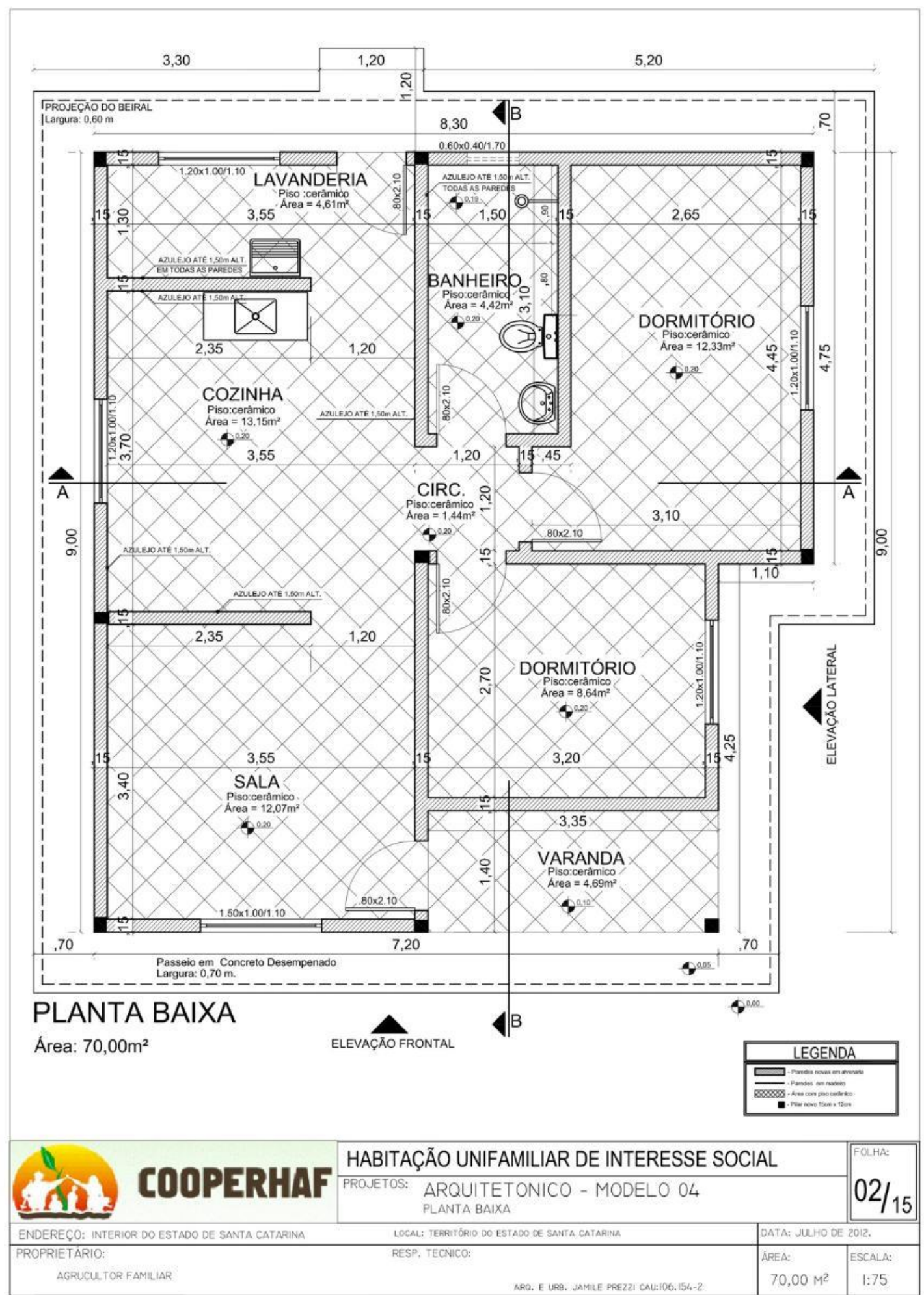


Figura 15: Planta da habitação "Modelo 5"

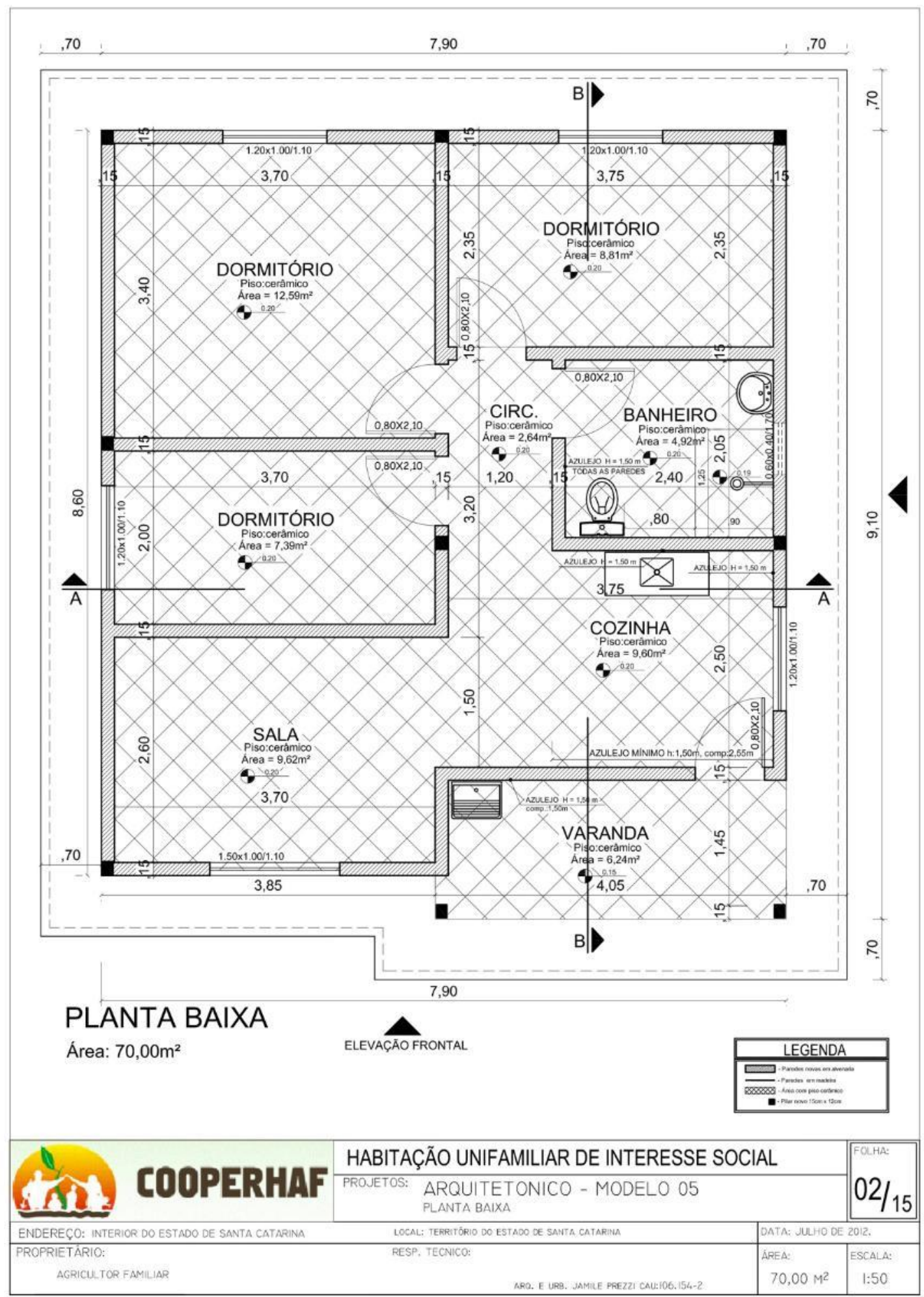


Figura 16: Planta da habitação "Modelo 6"

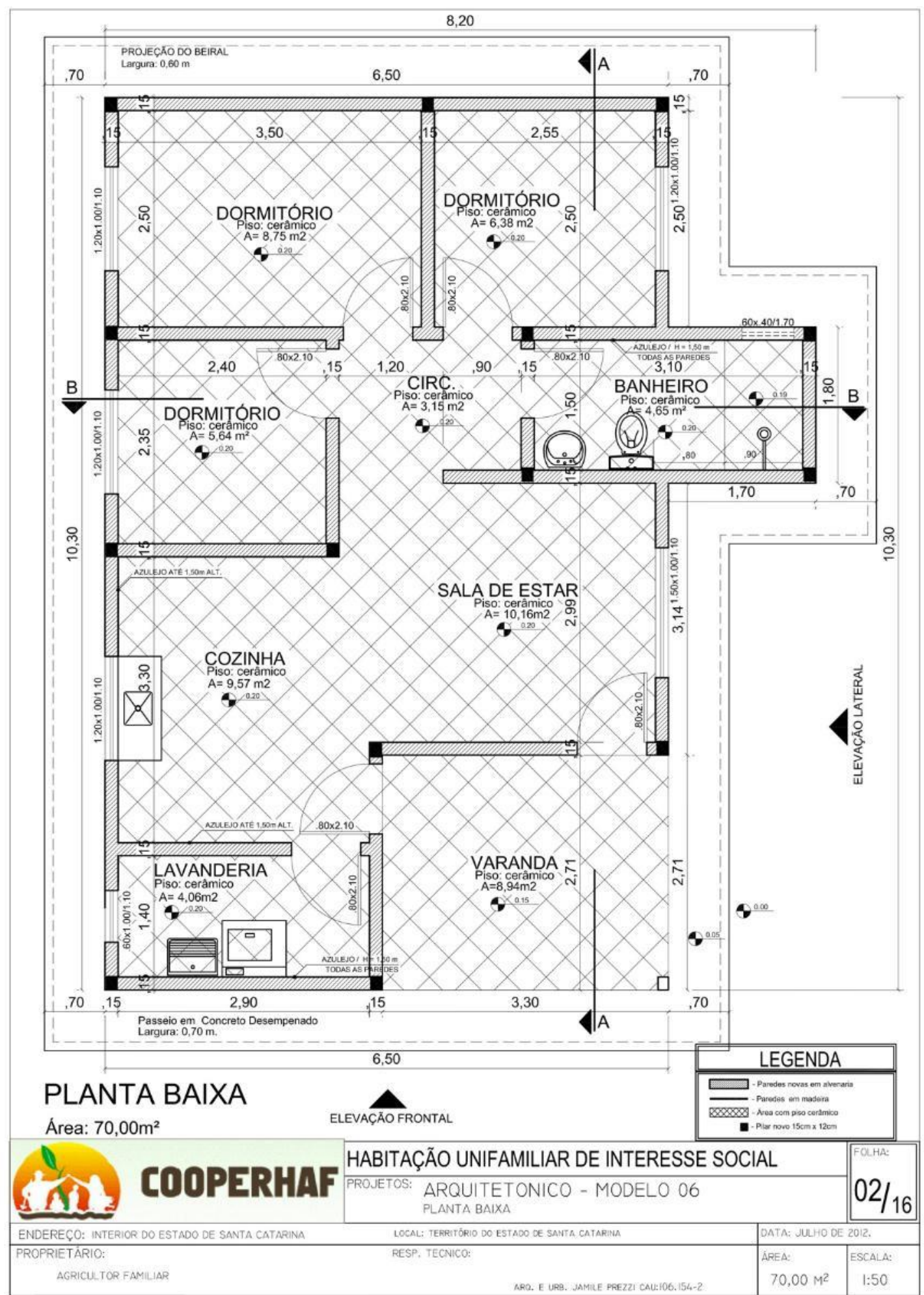


Figura 17: Planta da habitação "Modelo 7"

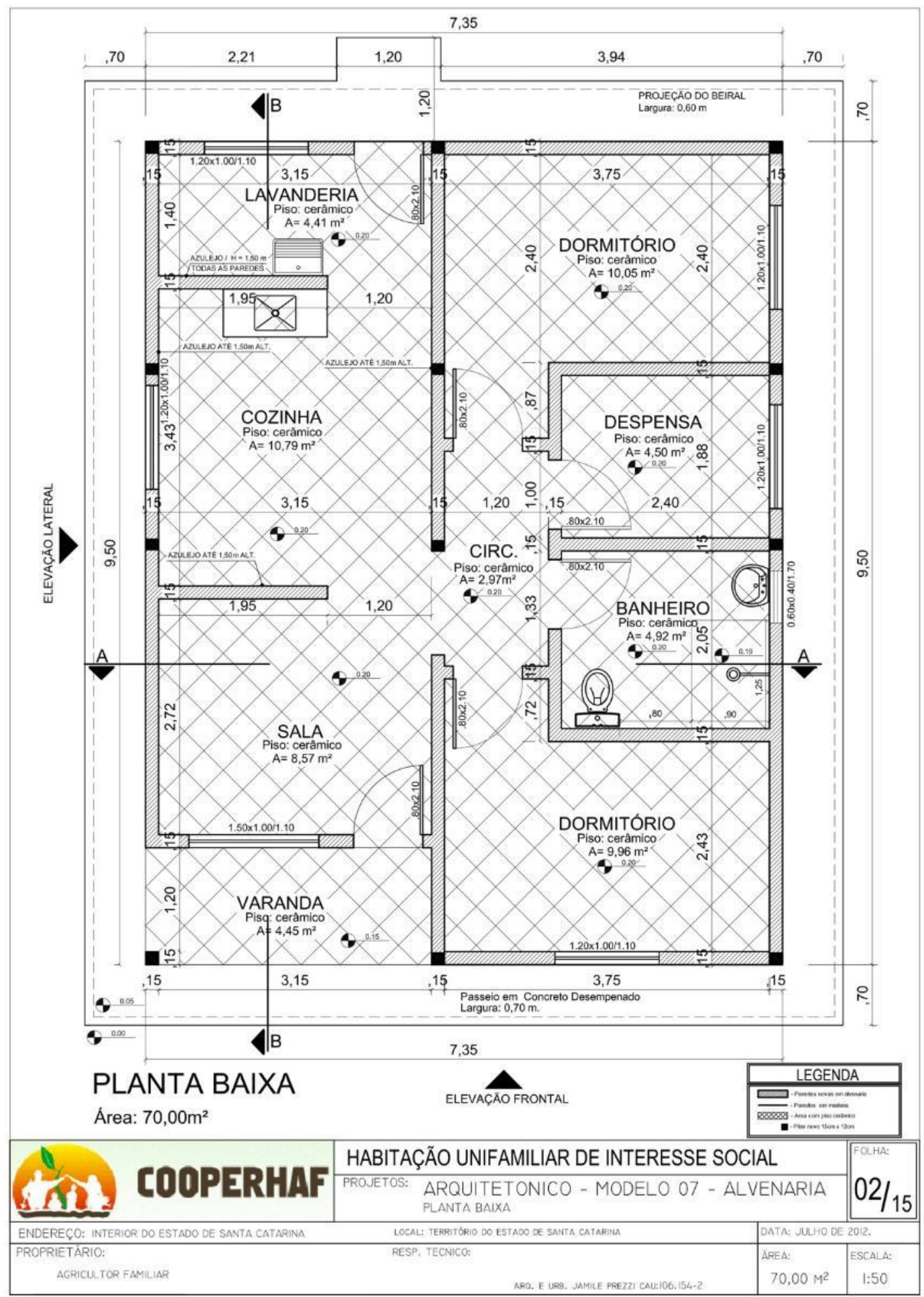


Figura 18: Planta da habitação "Modelo 9 acessível"

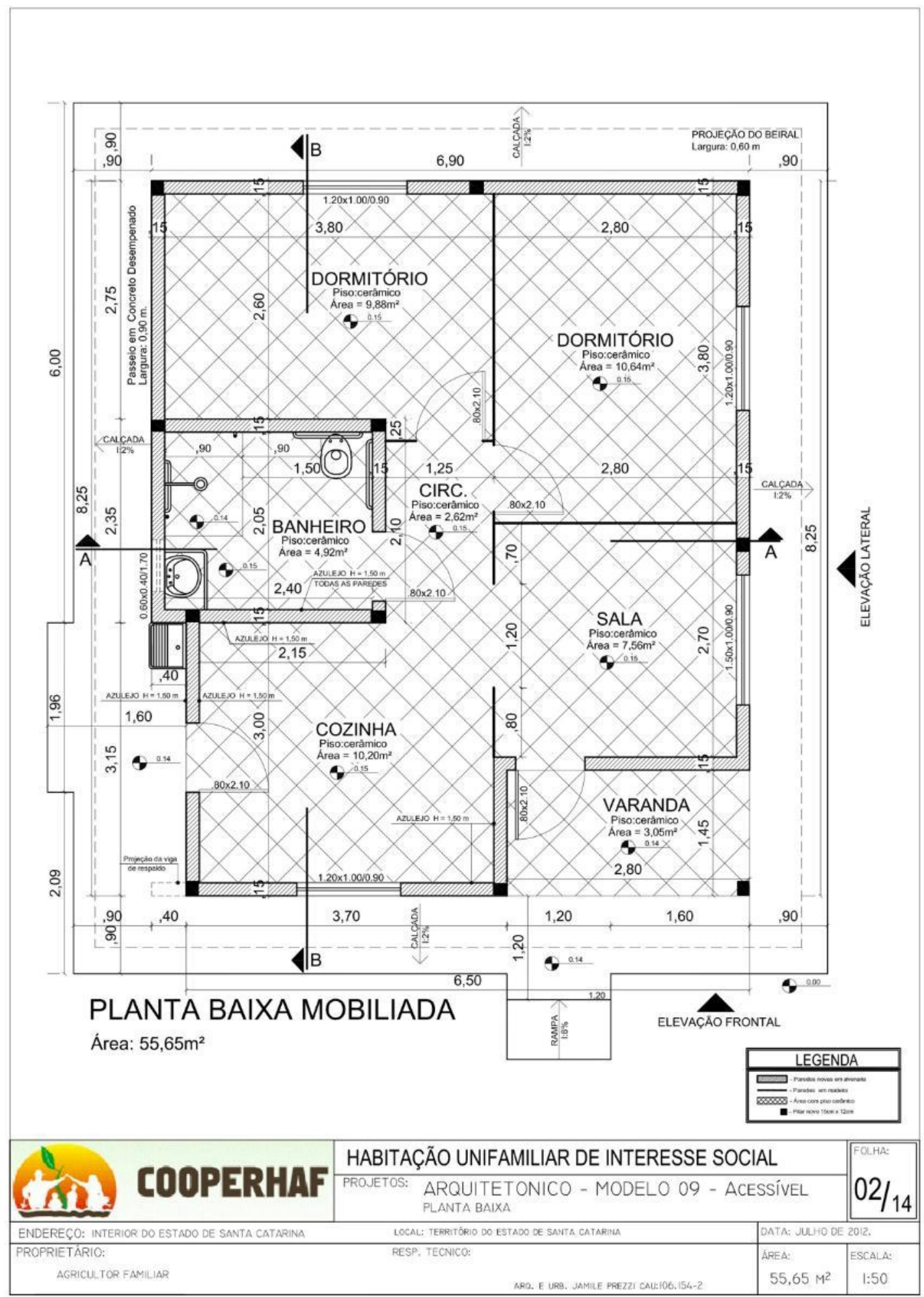


ANEXO C - Projeto arquitetônico completo da habitação "Modelo 1", pré-aprovado na CEF para uso no PNHR

Figura 19: Prancha 01/14, planta baixa mobiliada

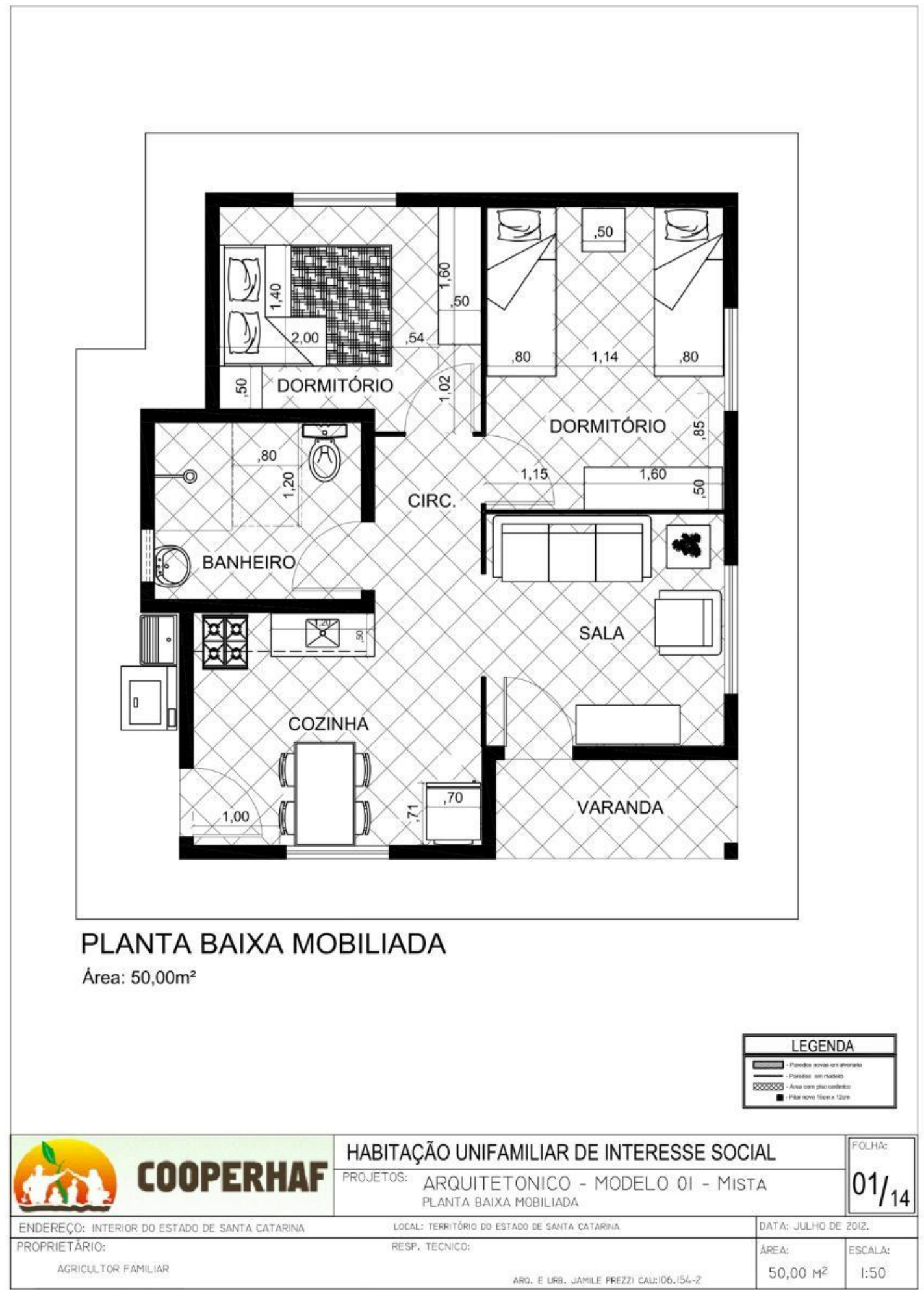


Figura 20: Prancha 02/14, planta baixa

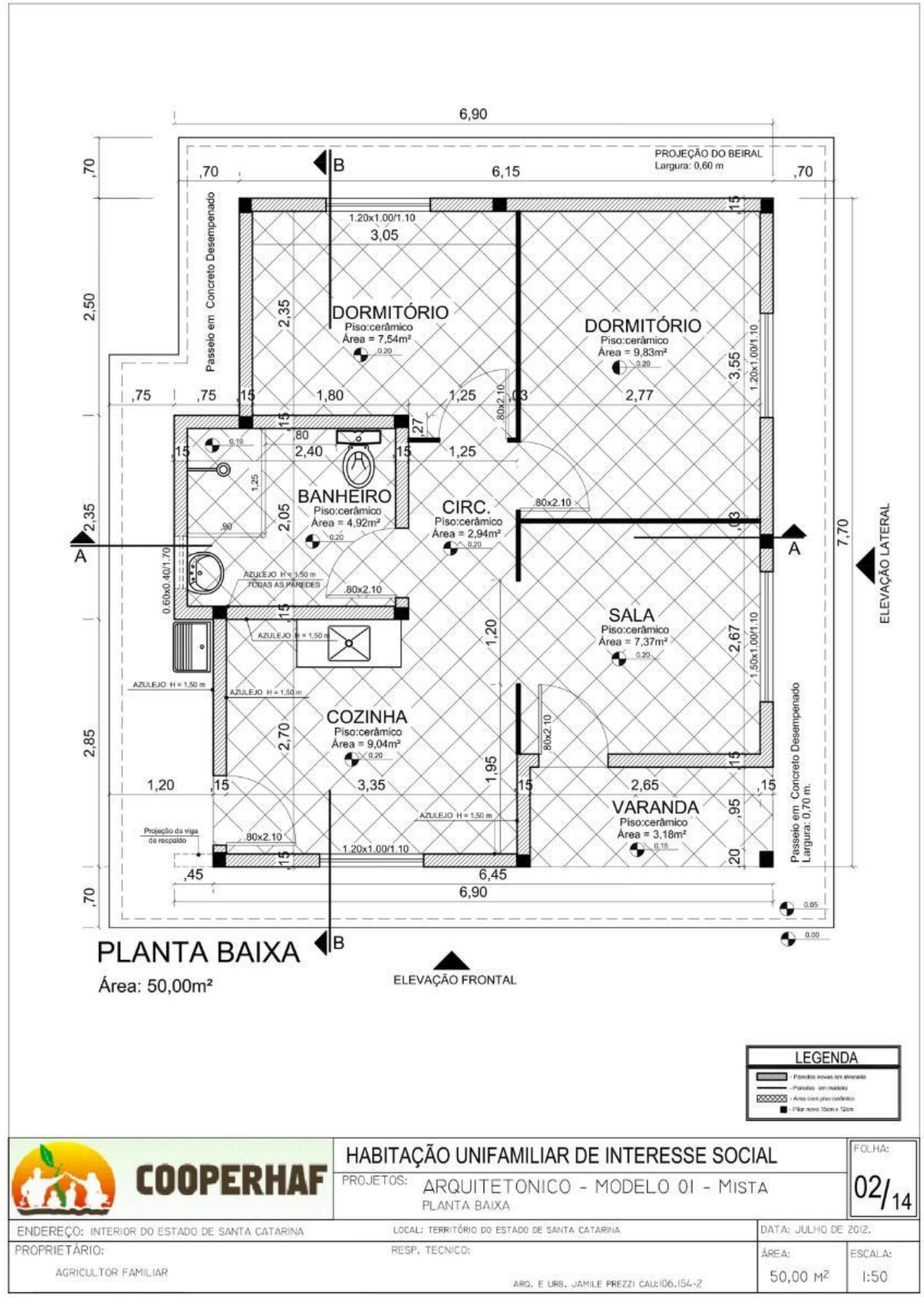


Figura 21: Prancha 03/14, corte transversal AA

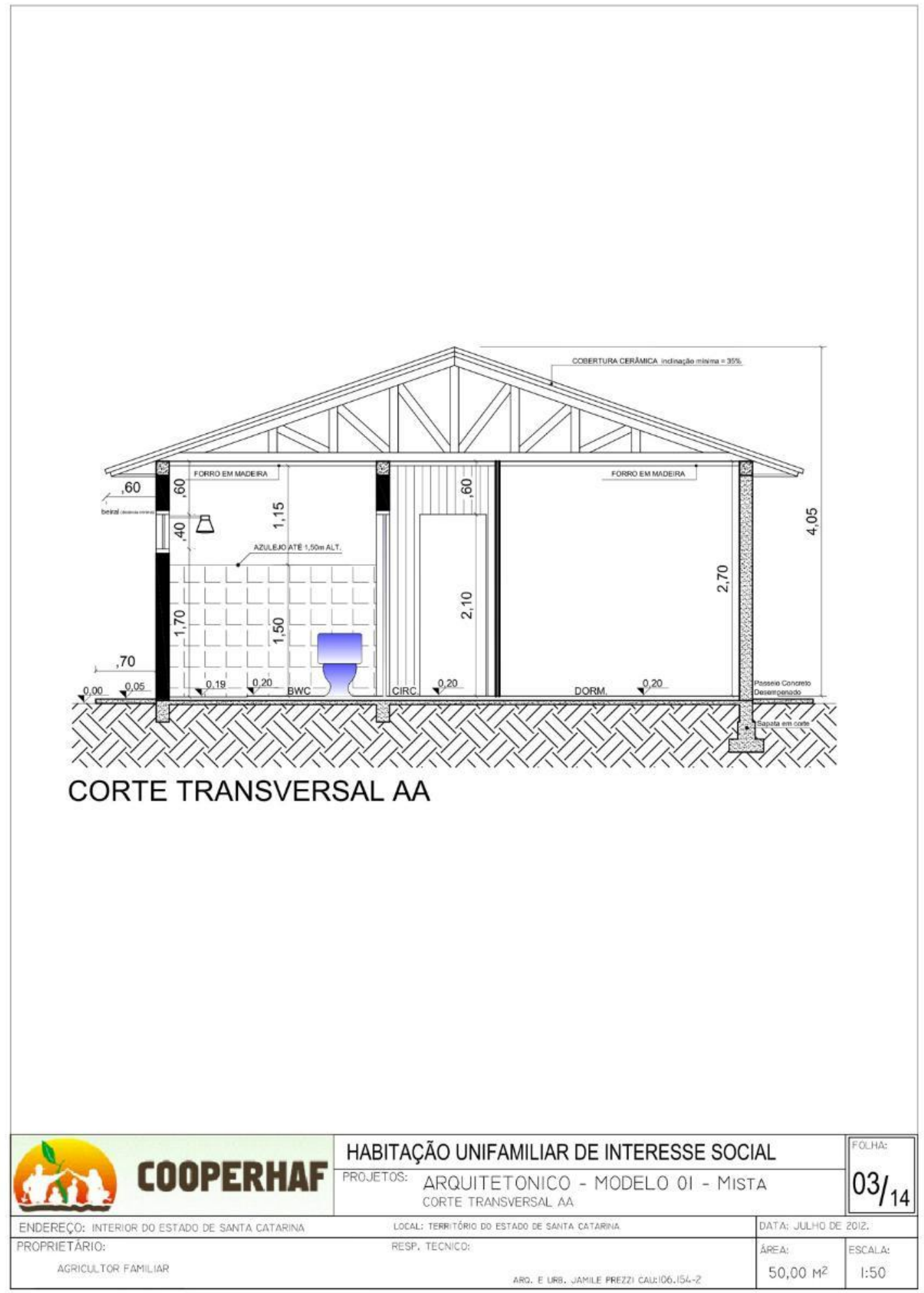


Figura 22: Prancha 04/14, corte longitudinal BB

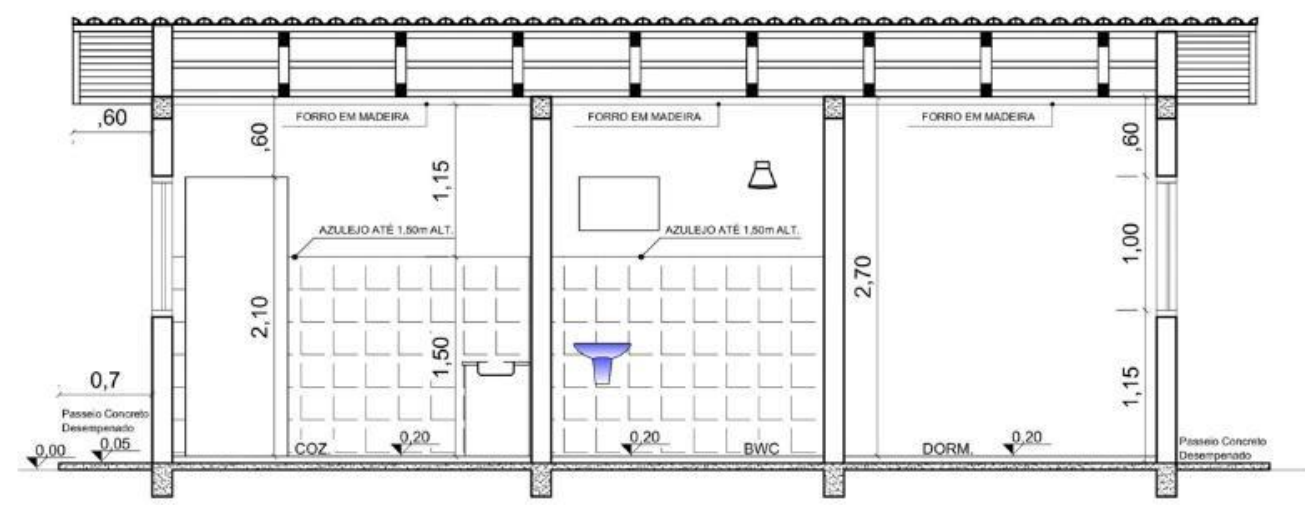

CORTE LONGITUDINAL BB

\begin{tabular}{|l|l|l||l||}
\hline & HABITAÇÃO UNIFAMILIAR DE INTERESSE SOCIAL & FOUHA: \\
\hline
\end{tabular}


Figura 23: Prancha 05/14, elevações

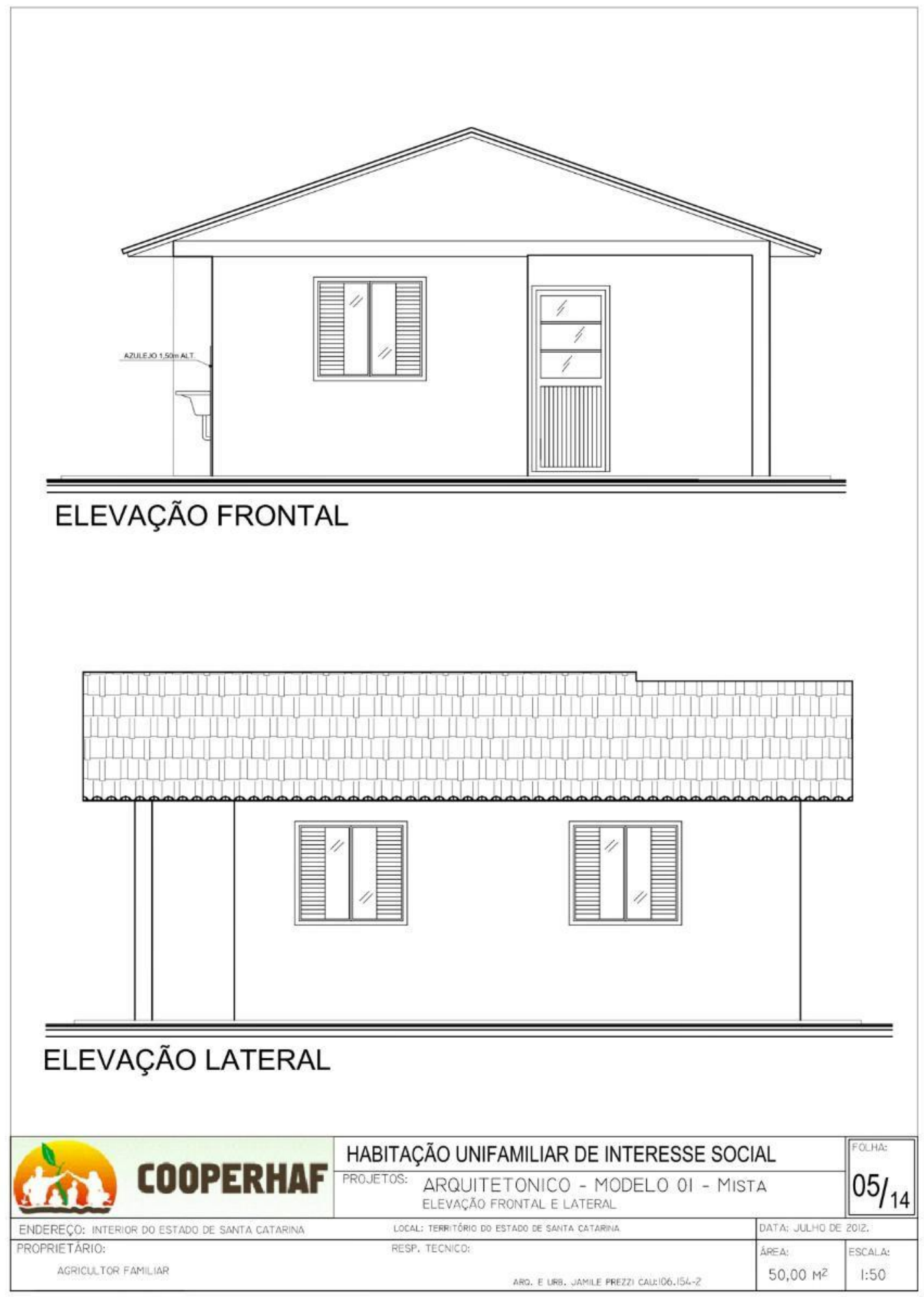


Figura 24: Prancha 06/14, planta de cobertura

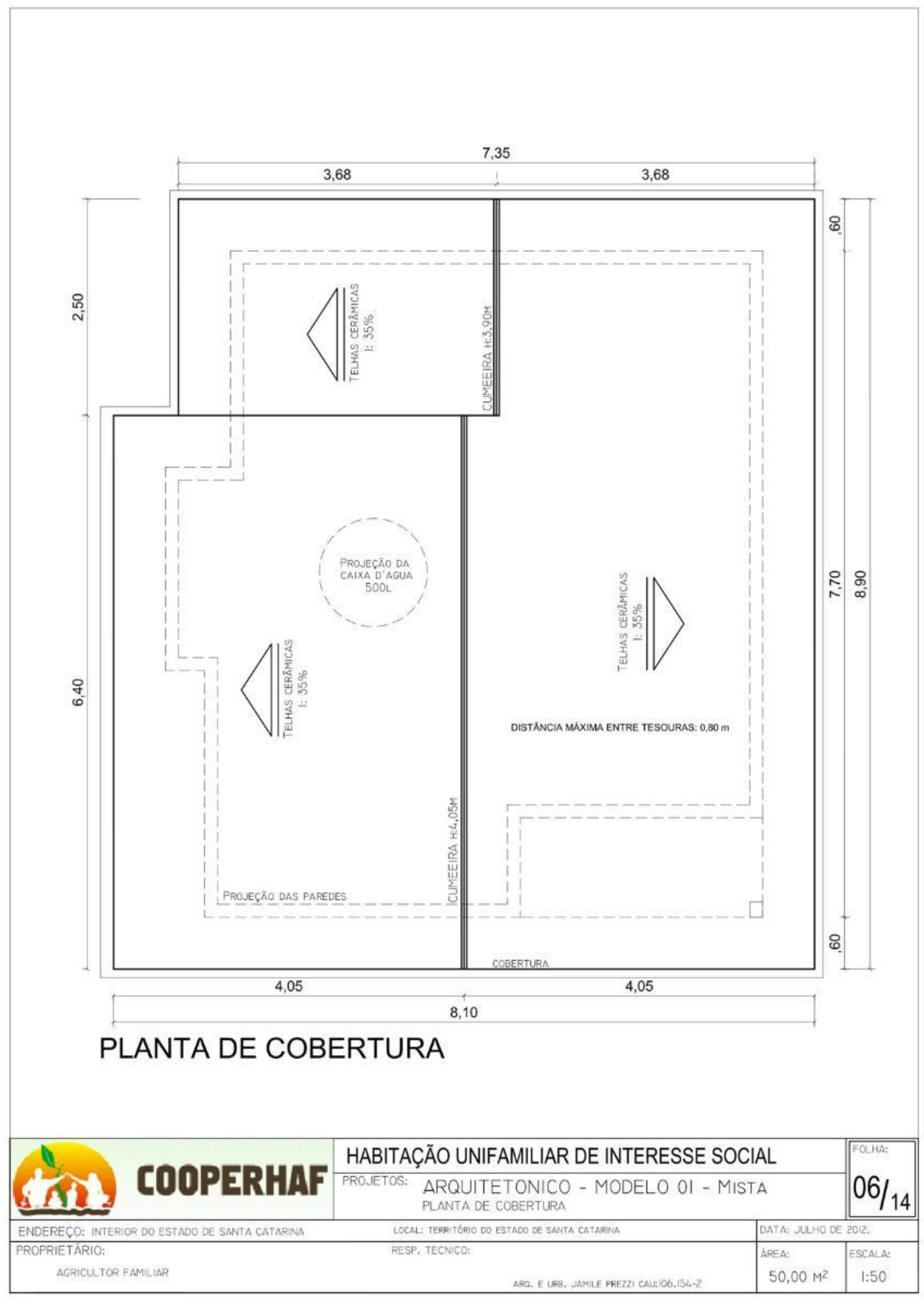


Figura 25: Prancha 07/14, projeto estrutural

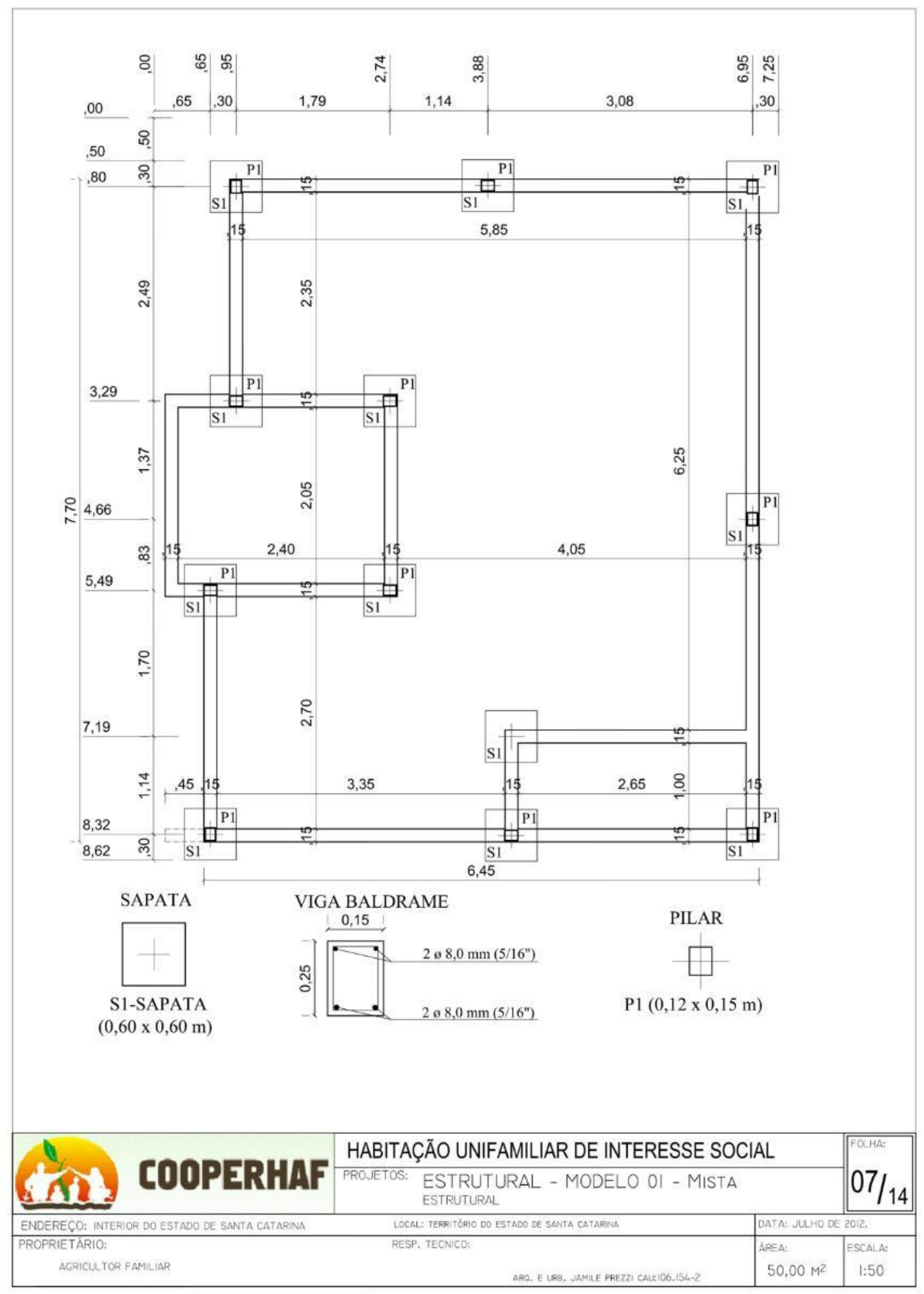


Figura 26: Prancha 08/14, projeto estrutural - detalhamento

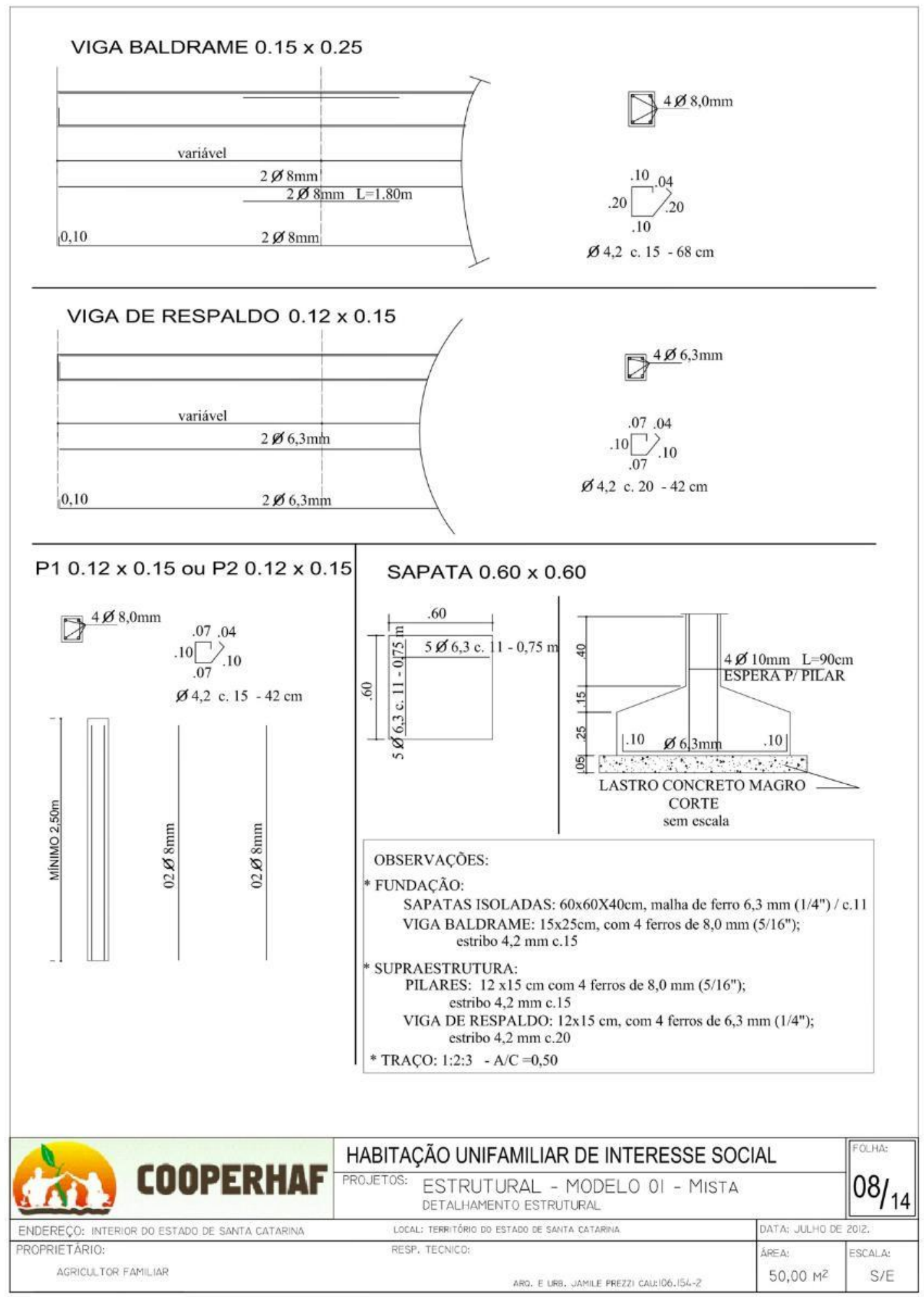


Figura 27: Prancha 09/14, projeto elétrico

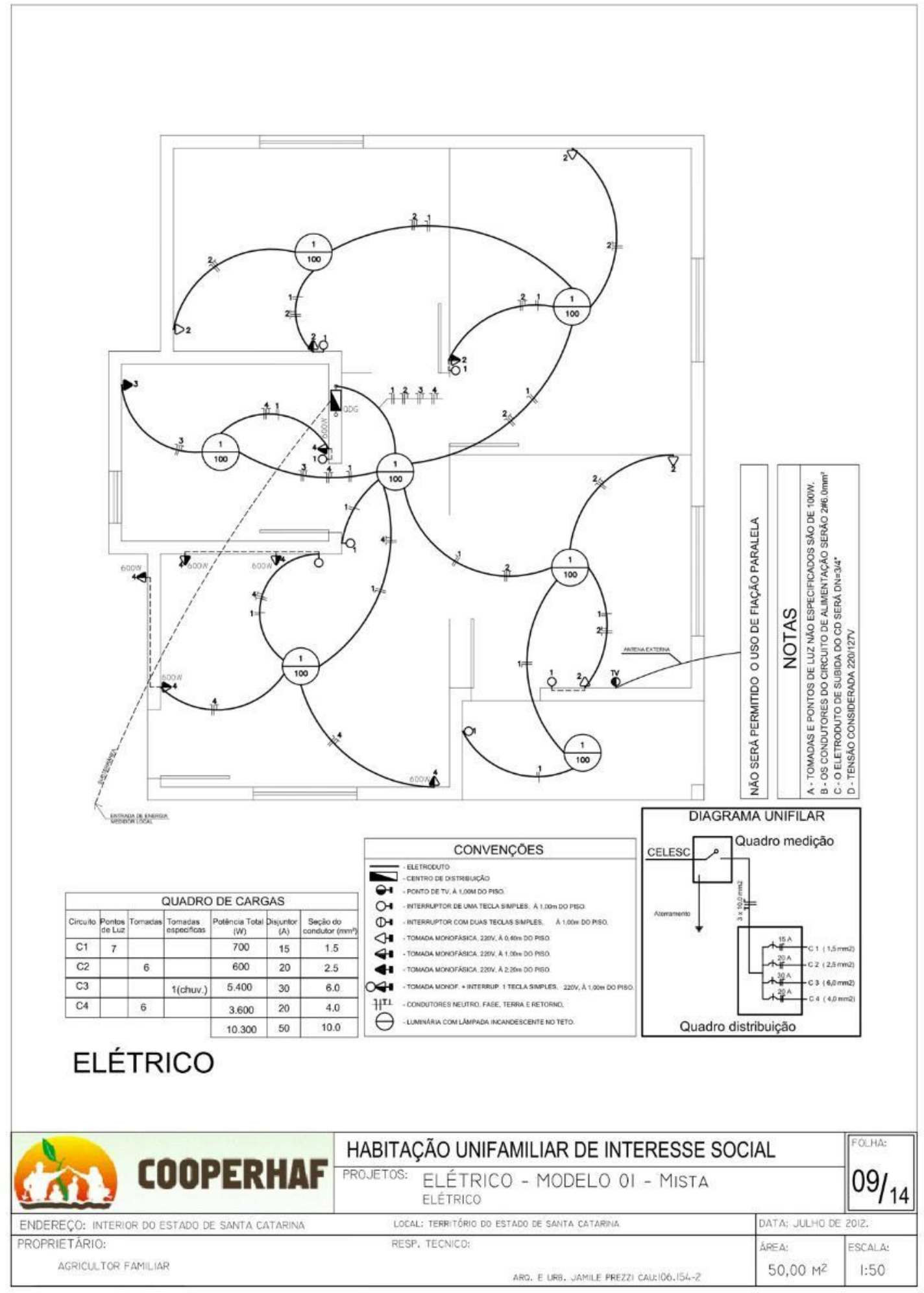


Figura 28: Prancha 10/14, projeto hidráulico

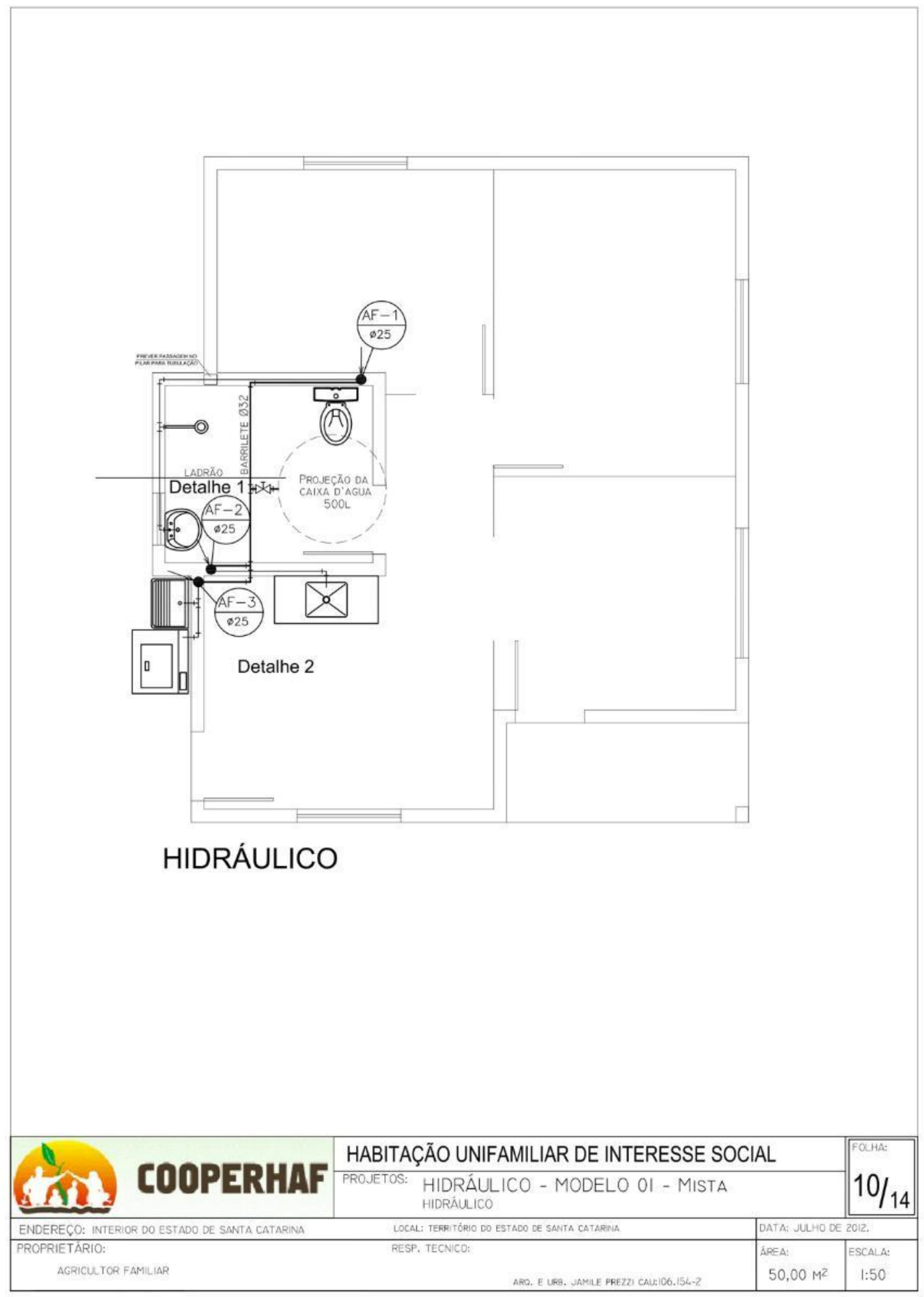


Figura 29: Prancha 11/14, projeto hidráulico - detalhamento

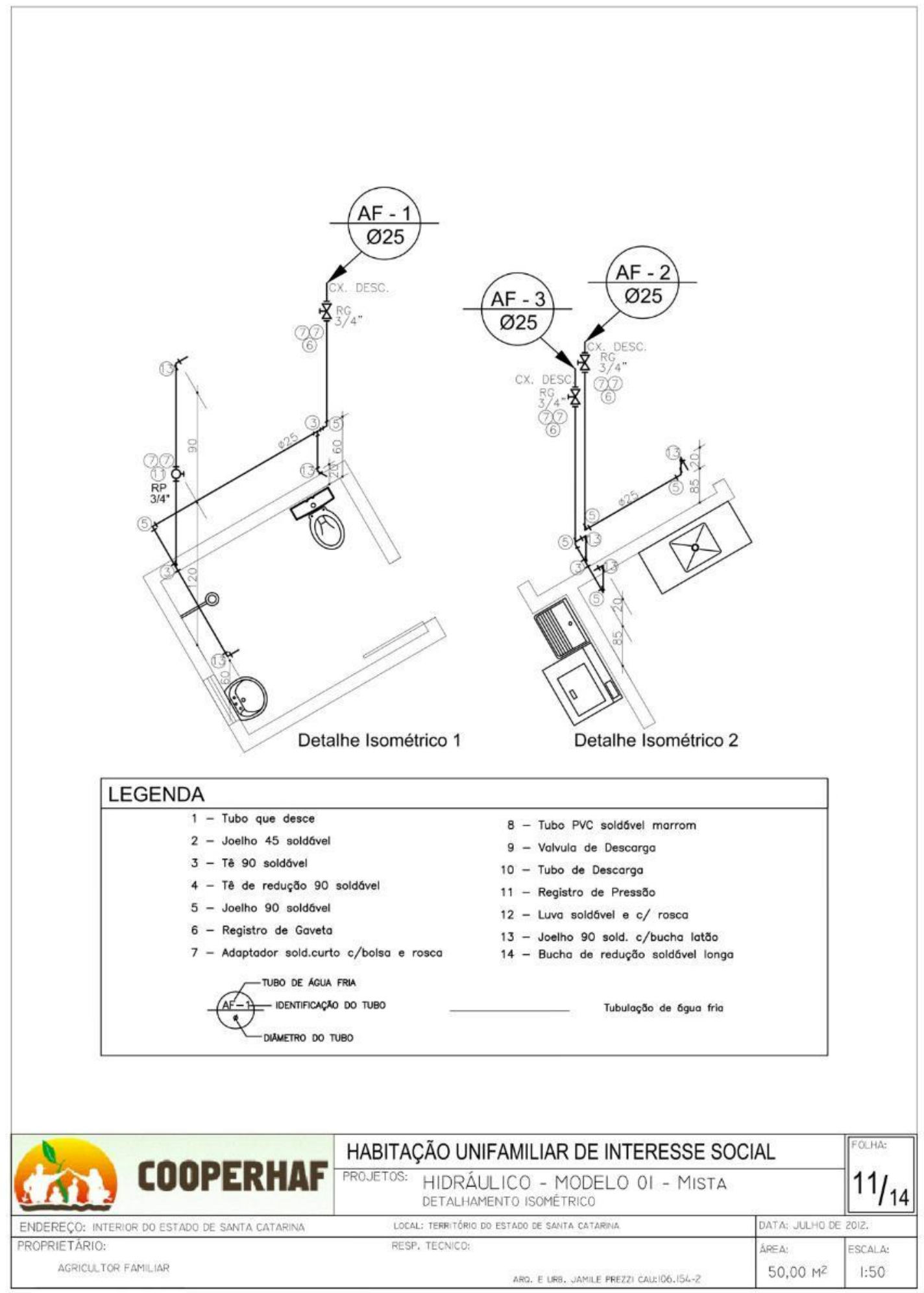


Figura 30: Prancha 12/14, projeto sanitário

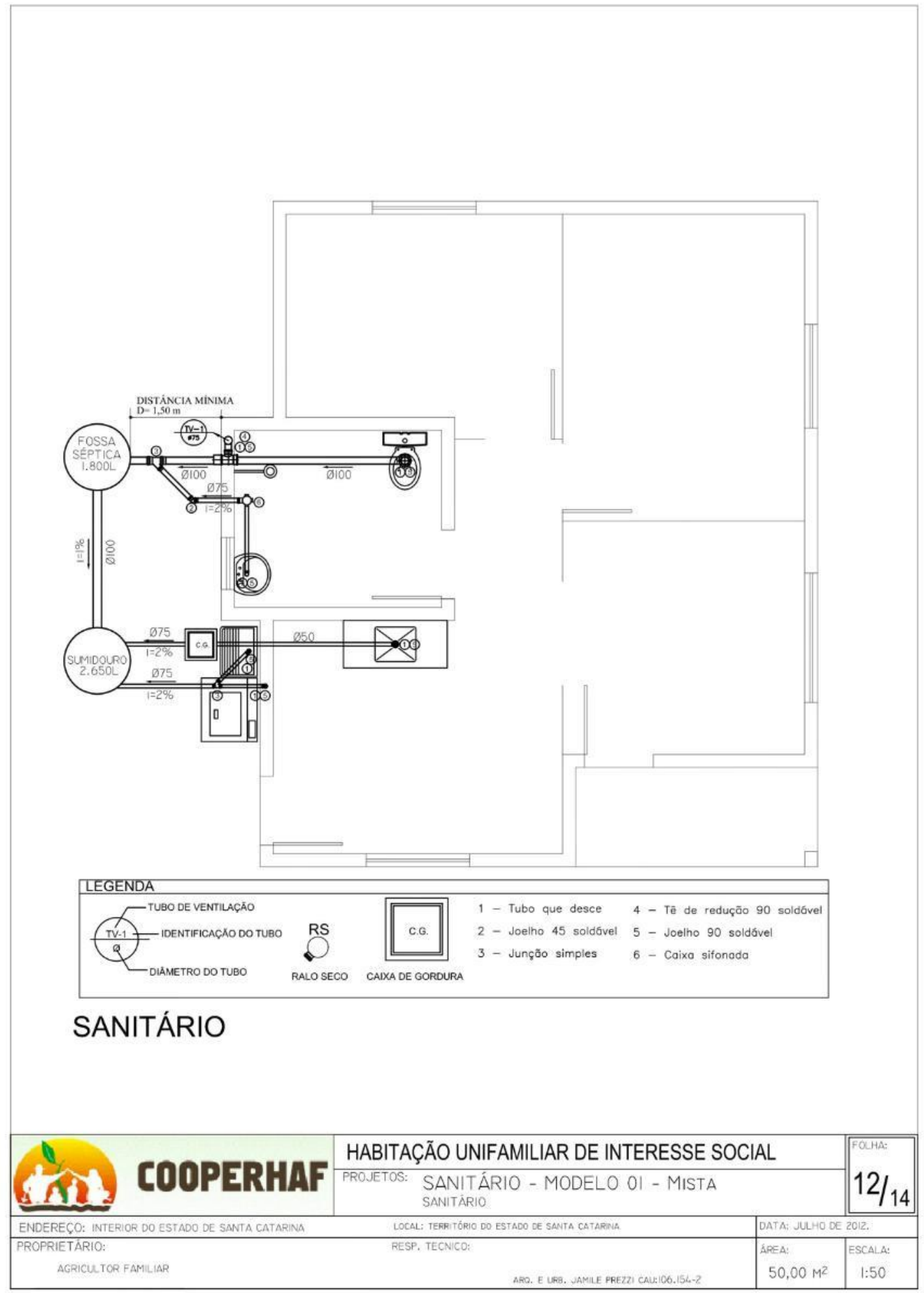


Figura 31: Prancha 13/14, projeto sanitário - detalhamento

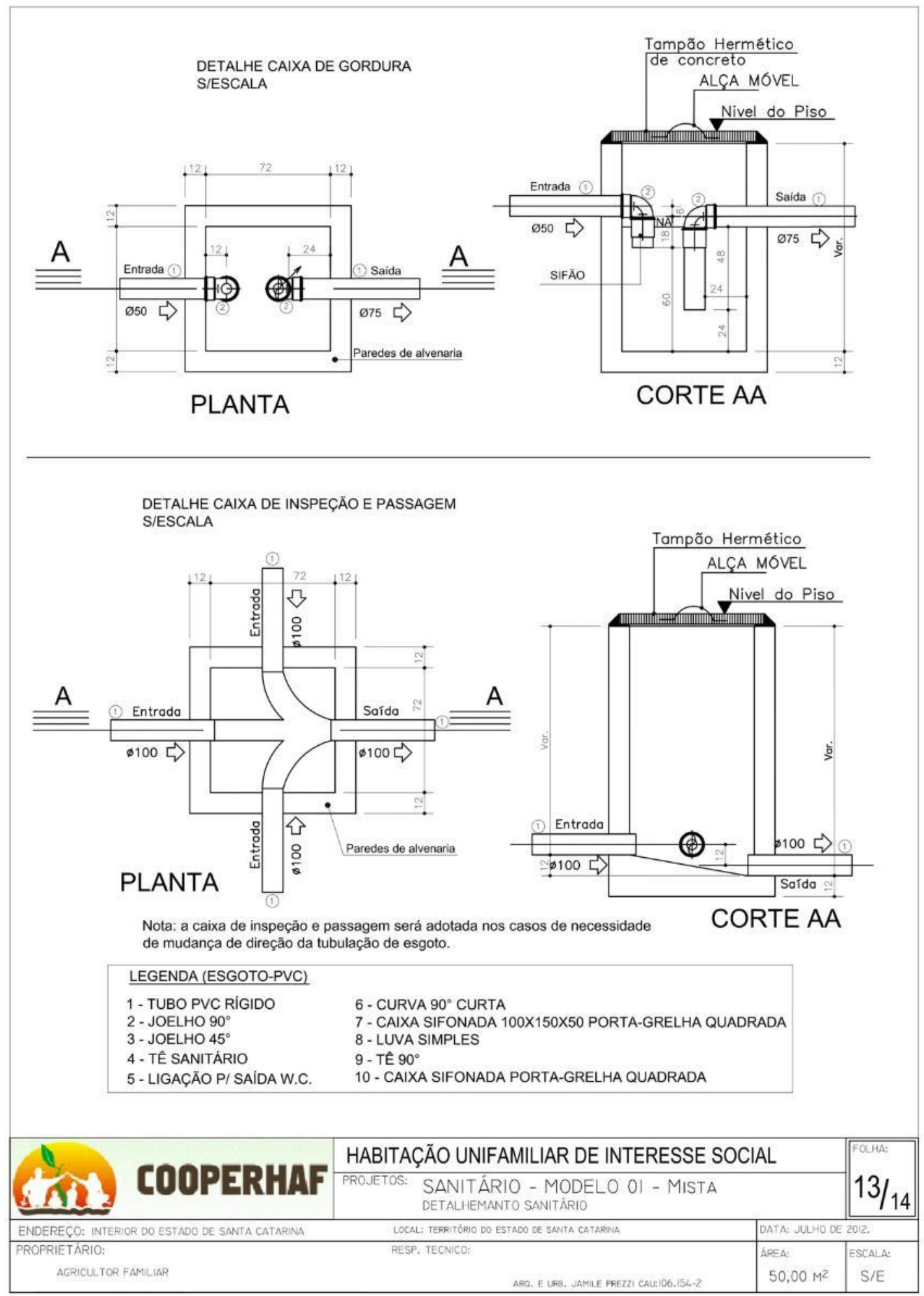


FOSSA SEPTICA

Volume útil $=1,8 \mathrm{~m}^{3}$

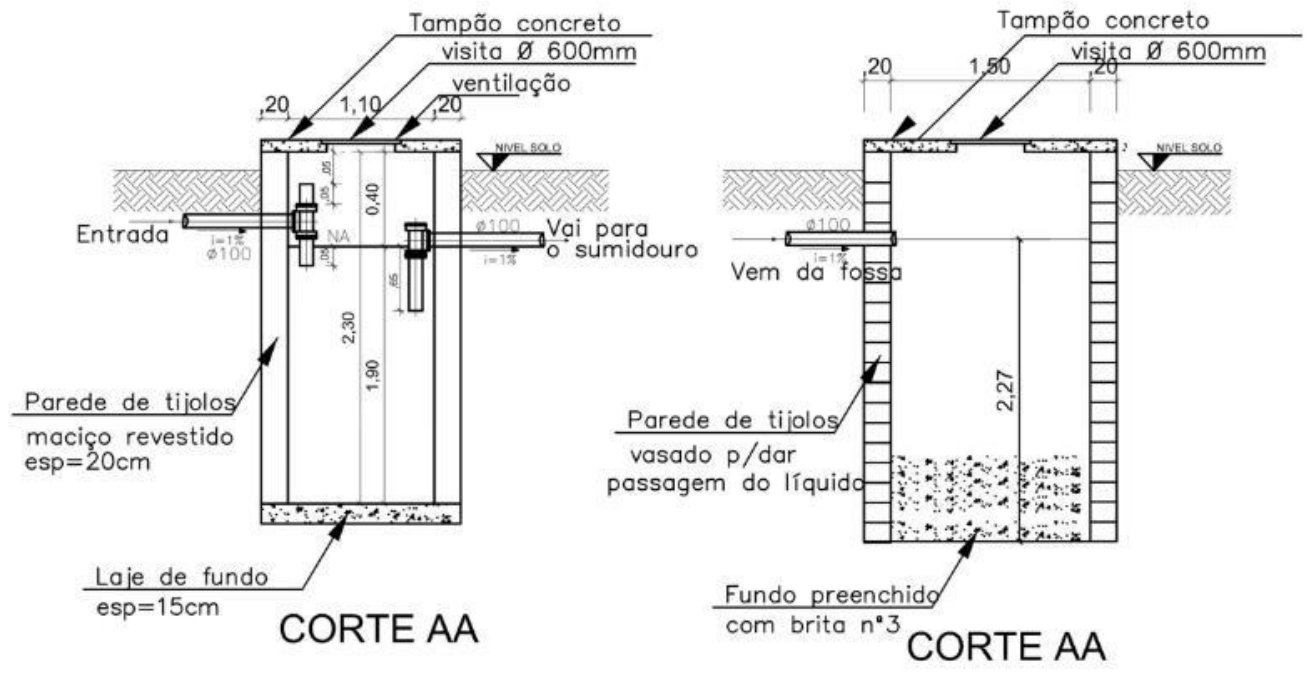

\section{SUMIDOURO}
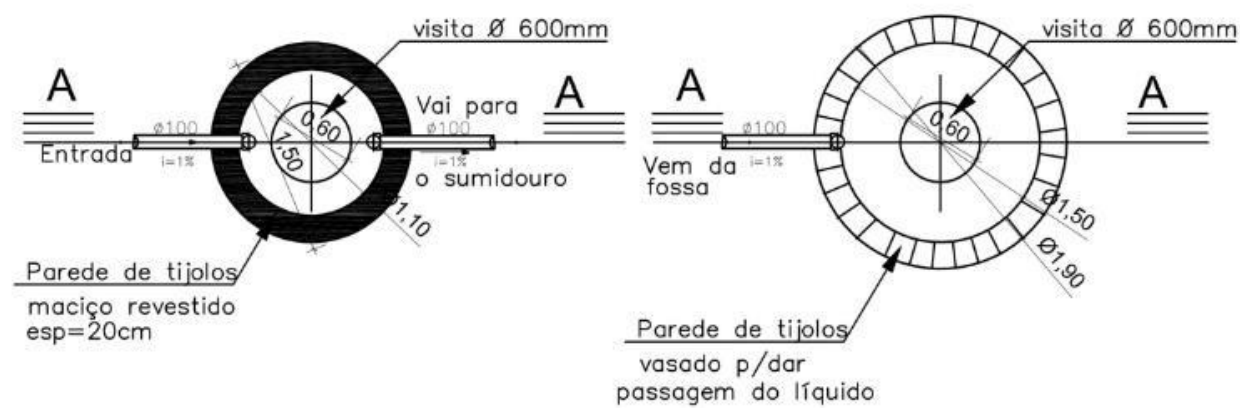

PLANTA BAIXA

FOSSA SEPTICA

PLANTA BAIXA

SUMIDOURO

\begin{tabular}{|c|c|c|c|c|}
\hline a & \multicolumn{3}{|c|}{ HABITAÇÃO UNIFAMILIAR DE INTERESSE SOCIAL } & \multirow{2}{*}{$14 / 14$} \\
\hline A. 12 & PROJETOS: & $\begin{array}{l}\text { SANITÁRIO - MODELO OI - MISTA } \\
\text { FOSSA SETPTICA E SUMIDUURO }\end{array}$ & & \\
\hline ENDERECO: INTEROR DO ESTADO DE SANTA CATARINA & & TERPT TRPOO DO ESTADO OE SANTA CATARENA & DATA; JULHO DE & 2012. \\
\hline $\begin{array}{l}\text { PROPRIETARIO: } \\
\text { AGRICU TOR FAMLIAR }\end{array}$ & & TECNCO: & $50,00 \mathrm{M}^{2}$ & \\
\hline
\end{tabular}


ANEXO D - Detalhes de acessibilidade universal e ampliação futura do projeto arquitetônico da habitação "Modelo 1", pré-aprovado na CEF para uso no PNHR

Figura 33: Prancha A/ABCD, detalhes de acesso e banheiro
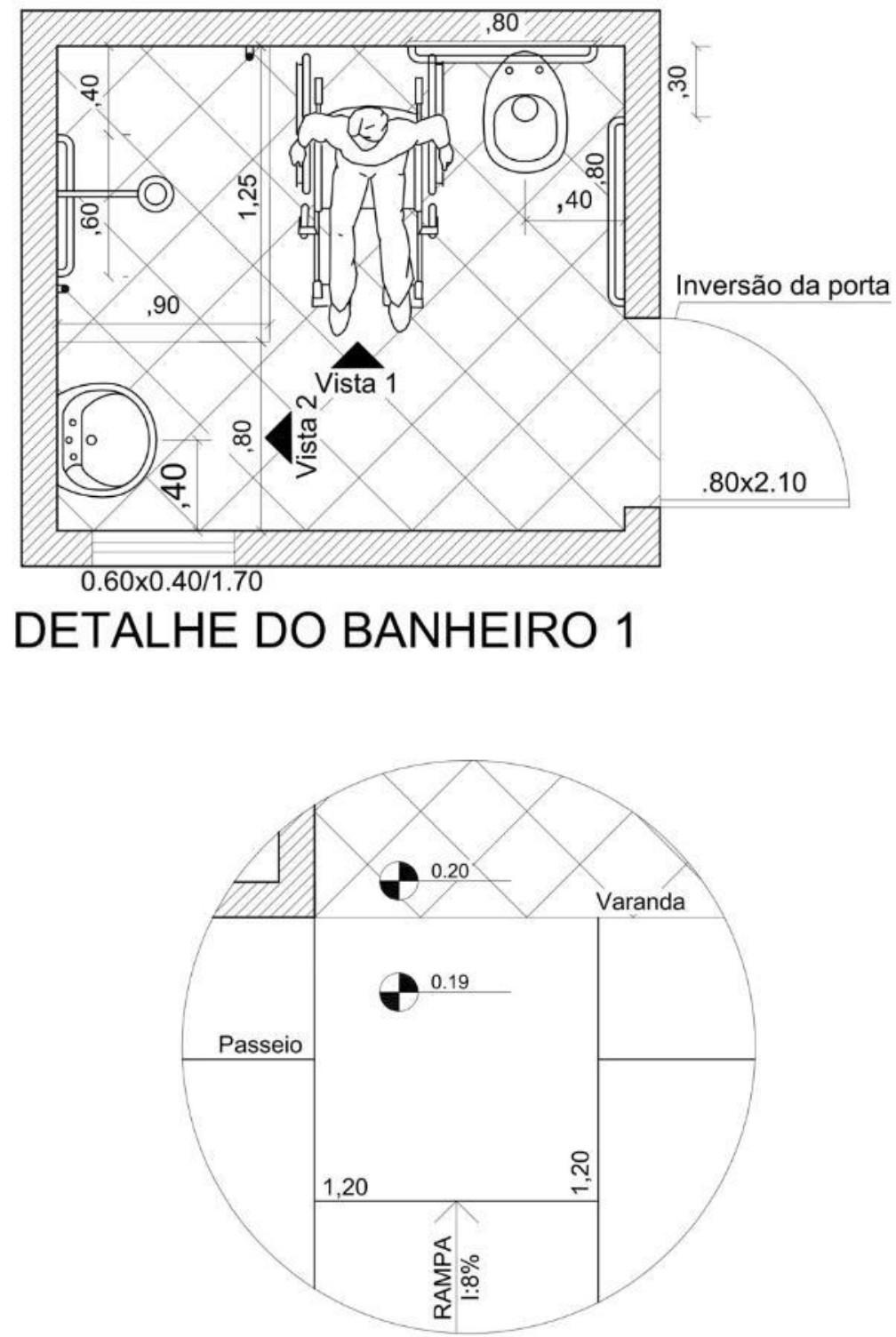

DETALHE DO ACESSO

OBS.: AS ADAPTAÇŌES de ACESSIBILIDADE NĀO ESTĀo ORÇADAS E SERÃO EXECUTADAS COMO CONTRAPARTIDA NOS GASOS NECESSÁRIOS

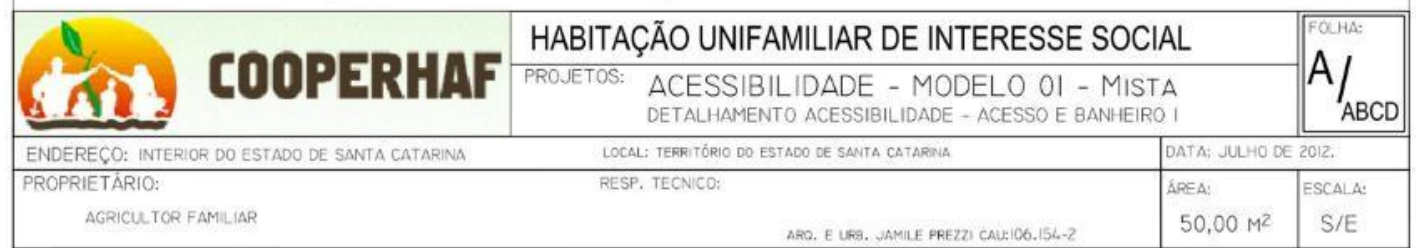


Figura 34: Prancha B/ABCD, detalhamento de acessibilidade do banheiro - vistas

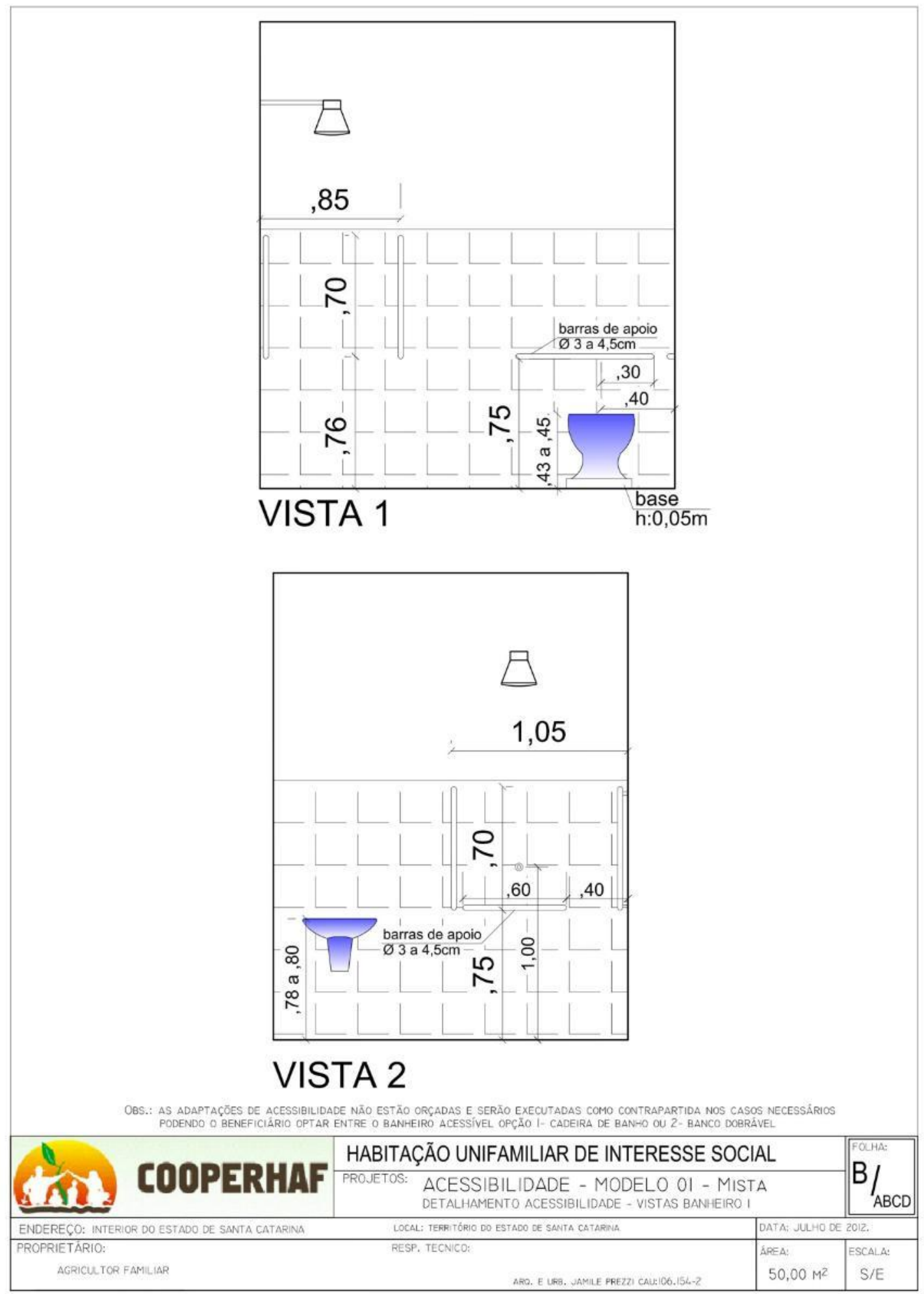


Figura 35: Prancha C/ABCD, detalhamento de acessibilidade do banheiro - banco dobrável

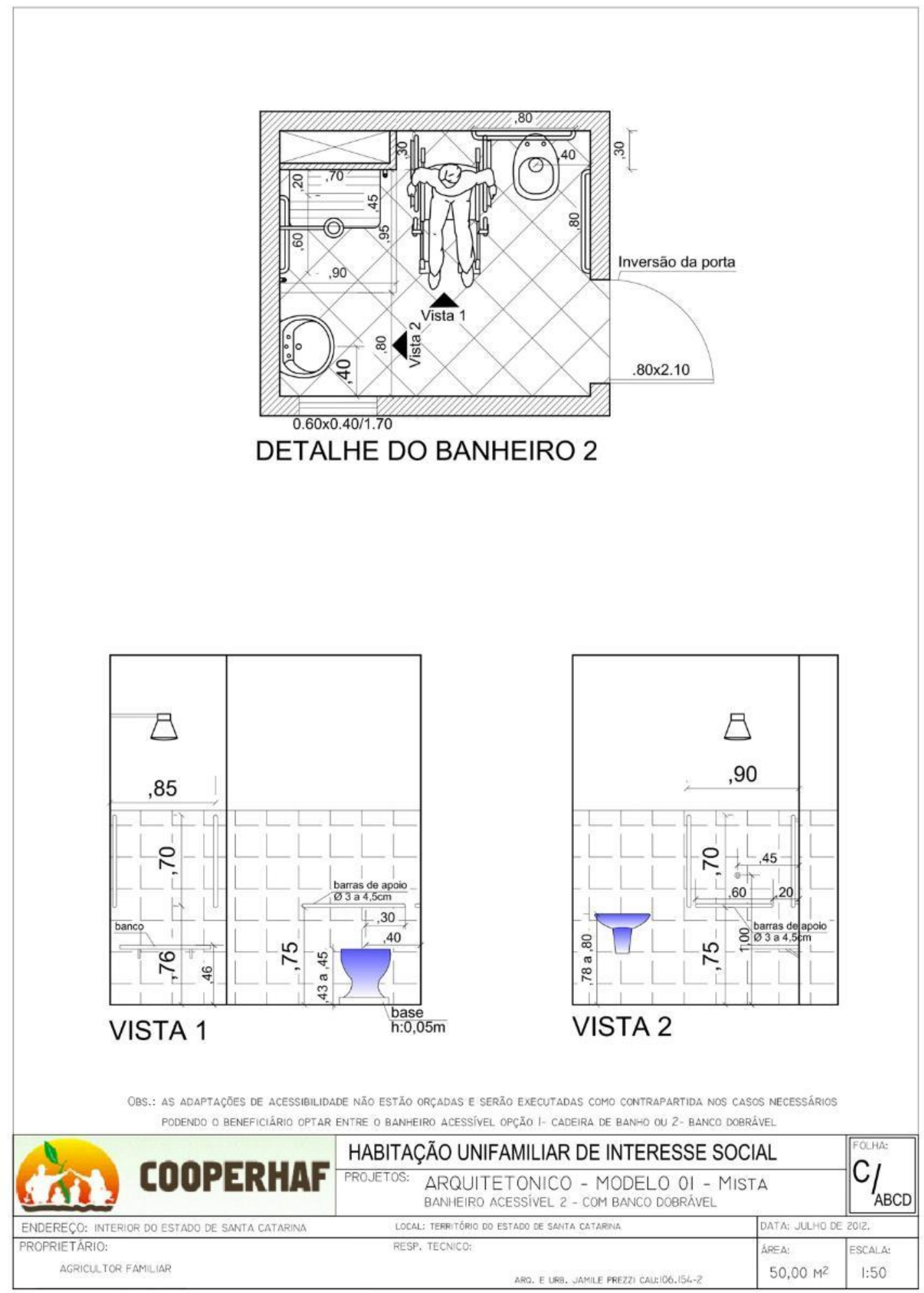


Figura 36: Prancha D/ABCD, layout ampliação futura

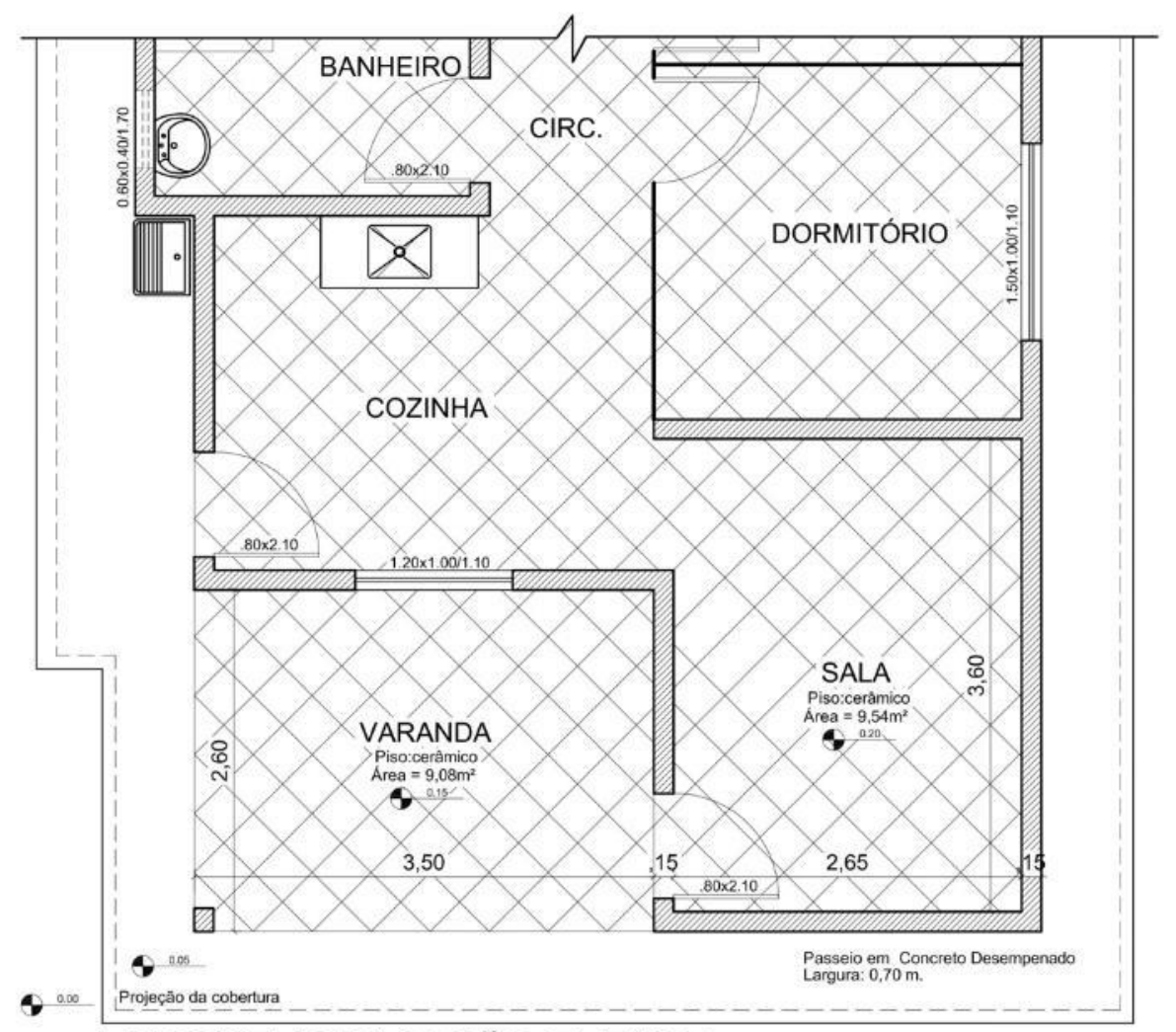

LAYOUT AMPLIAÇÃO FUTURA

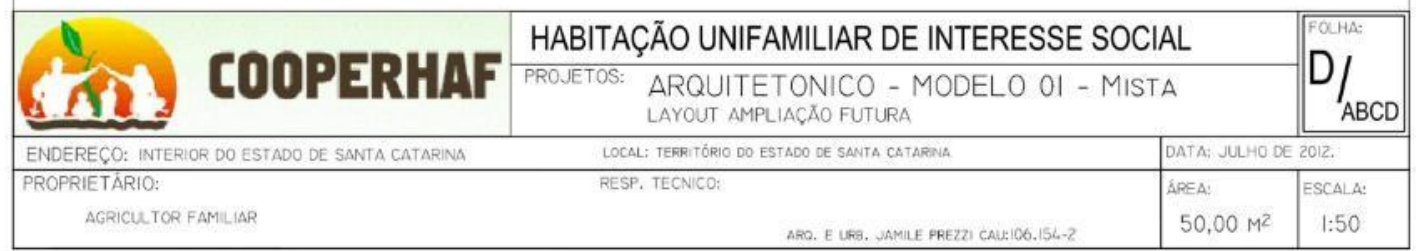


ANEXO E - Modelo do "Termo de consentimento livre e esclarecido" utilizado na pesquisa de campo

Figura 37: Termo de Consentimento Esclarecido

UNIVERSIDADE DE SÃO PAULO

INSTITUTO DE ARQUITETURA E URBANISMO

PROGRAMA DE PÓS-GRADUAÇÃO EM ARQUITETURA E URBANISMO

TERMO DE CONSENTIMENTO LIVRE E ESCLARECIDO

$\mathrm{Eu}$,

RG concordo em participar da pesquisa

intitulada provisoriamente "A Produção da Casa Camponesa em Santa Catarina: o PMCMV e as cooperativas rurais", desenvolvida pela estudante Cecília Corrêa Lenzi, mestranda do Programa de Pós-Graduação em Arquitetura e Urbanismo do IAU/USP, sob orientação do prof. João Marcos de Almeida Lopes.

Além disso, autorizo a utilização dos registros desta entrevista, quais sejam, anotações, gravação e fotografias, assim como minha identificação, para o desenvolvimento da pesquisa em questão.

O objetivo principal desta pesquisa é compreender o processo produtivo das unidades habitacionais, construídas sob a vigência do Programa Nacional de Habitação Rural - PNHR no estado de Santa Catarina, sob responsabilidade técnica da Cooperativa de Habitação dos Agricultores Familiares dos Três Estados do Sul Cooperhaf e acompanhamento do Sindicato dos Trabalhadores na Agricultura Familiar-SINTRAF

Qualquer dúvida pode ser esclarecida através do contato com a pesquisadora pelos telefones (48) 9956.0383 ou (11) 98885.0701 e ainda no email cecilialenzi@usp.br.

de setembro de 2015

Assinatura 